\title{
CONFLICT OF NATIONAL IDENTITY IN SUDAN
}

Kuel Maluil Jok

Academic Dissertation to be publicly discussed, by due permission of the Faculty of Arts at the University of Helsinki, in auditorium XII, on 31 March 2012 at 10 o'clock.

University of Helsinki, Department of World Cultures 
Kuel Jok

Conflict of National Identity in Sudan

Copyright (C) Kuel Jok 2012

ISBN 978-952-10-7919-1 (Print)

ISBN 978-952-10-7891-0 (PDF)

UNIGRAFIA Helsinki University Print

Helsinki 2012 


\section{ABSTRACT}

This study addresses the contemporary conflict of national identity in Sudan between the adherents of 'Islamic nationalism' and 'customary secularism'. The former urge the adoption of a national constitution that derives its civil and criminal laws from Sharia (Islamic law) and Arabic be the language of instruction in national institutions of Sudan. The group argues that the intertwined model of the Islamic-Arab cultural identity accelerates assimilation of the heterogeneous African ethnic and religious diversities in Sudan into a homogeneous national identity defining Sudan as an Islamic-Arab state. The latter demand the adoption of secular laws, which must be derived from the diverse set of customary laws and equal opportunities for all African languages beside Arabic and English. The group claims that the adoption of the Islamic laws and Arabic legalises the treatment of the citizens in the country in terms of religion and race and that implies racism and discrimination. In this way, the adherents of the Islamic nationalis m imposed the Islamic-Arab model. In reaction, the Muslims and the non-Muslim secularists resort to violence as an alternative model of resistance. In pursuance of war, the Islamists declared Jihad against the secularists in Nuba Mountains, South Blue Nile (Ingessana) and adopt the racial war in Darfur. In this region, the janjaweed (armed Arab militias) in Darfur fight inclusively the insurgents and the indigenous African Muslims in Darfur in equal terms. This form of war has caused a humanitarian disaster in this region. The method of the research is qualitative and its main primary source material was based on a survey conducted among students of five universities in Sudan. Prepared and organised questionnaires in English and Arabic were given to five hundred students. Participant observation, interviews and relevant secondary sources were also used. The findings of the study indicate that every religion and culture in Sudan provides a set of regulations which promote political ethics of cultural and religious diversities as well as equal distribution of power and national wealth. The new emerging phenomenon that attempts to project religion as the source of human insecurity and injustice embodies some psychological and ideological orientations emanating from human nature and not the historical religions of God. It recommends the durable resolutions taking into consideration the diverse theoretical models for the formation of a nation-state, where the diversity is not discouraged; instead states apply laws which promote religious and ethnic diversities within one territorial state. The insistence of the Islamists on the application of the Islamic law and marginalisation of the non-Arab groups in Darfur, Eastern Sudan of Beja, Ingessana of South Blue Nile and Nuba Mountains threaten the territorial integrity of the state. The secession of South Sudan from the current Sudan in the internationally surpvised referendum in January 2011 was a paradigm resulting from economic and political imbalance in the former Sudan. 


\section{ACRONYMS}

\begin{tabular}{|c|c|}
\hline ACHPR & African Charter on Human and People's Rights \\
\hline AL & Arab League \\
\hline AU & African Union \\
\hline CPA & Comprehensive Peace Agreement \\
\hline DDF & Darfur Development Front \\
\hline DLF & Darfur Liberation Front \\
\hline DOP & Declaration of Principles \\
\hline DUP & Democratic Unionist Party \\
\hline EU & European Union \\
\hline GDP & Gross Domestic Product \\
\hline GONU & Government of National Unity \\
\hline GoS & Government of Sudan \\
\hline GUN & Union of the Nuba Mountains \\
\hline $\mathrm{HAC}$ & Humanitarian Affairs Commission \\
\hline HAMAS & Islamic Resistance Movement \\
\hline HROs & Human Rights Offices \\
\hline HRW & Human Rights Watch \\
\hline ICC & International Criminal Court \\
\hline ICF & Islamic Charter Front \\
\hline IDPs & Internally Displaced Persons \\
\hline IGAD & Intergovernmental Authority for Development \\
\hline IGADD & $\begin{array}{l}\text { Intergovernmental Authority for Drought and } \\
\text { Development }\end{array}$ \\
\hline JEM & Justice and Equality Movement \\
\hline MI & Military Intelligence \\
\hline MPs & Members of Parliament \\
\hline NANS & National Alliance for National Salvation \\
\hline $\mathrm{NCP}$ & National Congress party \\
\hline NDA & National Democratic Alliance \\
\hline NGOs & Non-Governmental Organisations \\
\hline NIF & National Islamic Front \\
\hline NSR & National Salvation Revolution \\
\hline NTC & National Television of Sudan \\
\hline OPEC & Organisation for Petroleum Exporting Countries \\
\hline PAEC & Parliamentary Assessment of Evaluation Commission \\
\hline PCP & Popular Congress Party \\
\hline POL & Public Order Law \\
\hline PPO & Police of Public Order \\
\hline $\mathrm{RCC}$ & Revolutionary Command Council \\
\hline
\end{tabular}




$\begin{array}{ll}\text { RSG } & \text { Regional Self-Government } \\ \text { SAF } & \text { Sudan Armed Forces } \\ \text { SCC } & \text { Sudan Council of Churches } \\ \text { SCP } & \text { Sudanese Communist Party } \\ \text { SHRO } & \text { Sudanese Human Rights Organisation } \\ \text { SLA } & \text { Sudan Liberation Army } \\ \text { SLM } & \text { Sudan Liberation Movement } \\ \text { SNP } & \text { Sudanese National Party } \\ \text { SPI } & \text { Sudanese Peace Initiative } \\ \text { SPLA } & \text { Sudan People's Liberation Army } \\ \text { SPLM } & \text { Sudan People's Liberation Movement } \\ \text { SSLM } & \text { South Sudan Liberation Movement } \\ \text { SSU } & \text { Sudanese Socialist Union } \\ \text { SVTG } & \text { Sudan Victims of Torture Group } \\ \text { TGOD } & \text { Transitional Government of Darfur States } \\ \text { TMC } & \text { Transitional Military Council } \\ \text { UK } & \text { United Kingdom } \\ \text { UN } & \text { United Nations } \\ \text { UNAMID } & \text { United Nations/African Union Mission in Darfur } \\ \text { UNHCR } & \text { United Nations High Commissioner for Refugees } \\ \text { USA } & \text { United States of America } \\ \text { USAP } & \text { Union of Sudan African Parties }\end{array}$




\section{MAP 1}

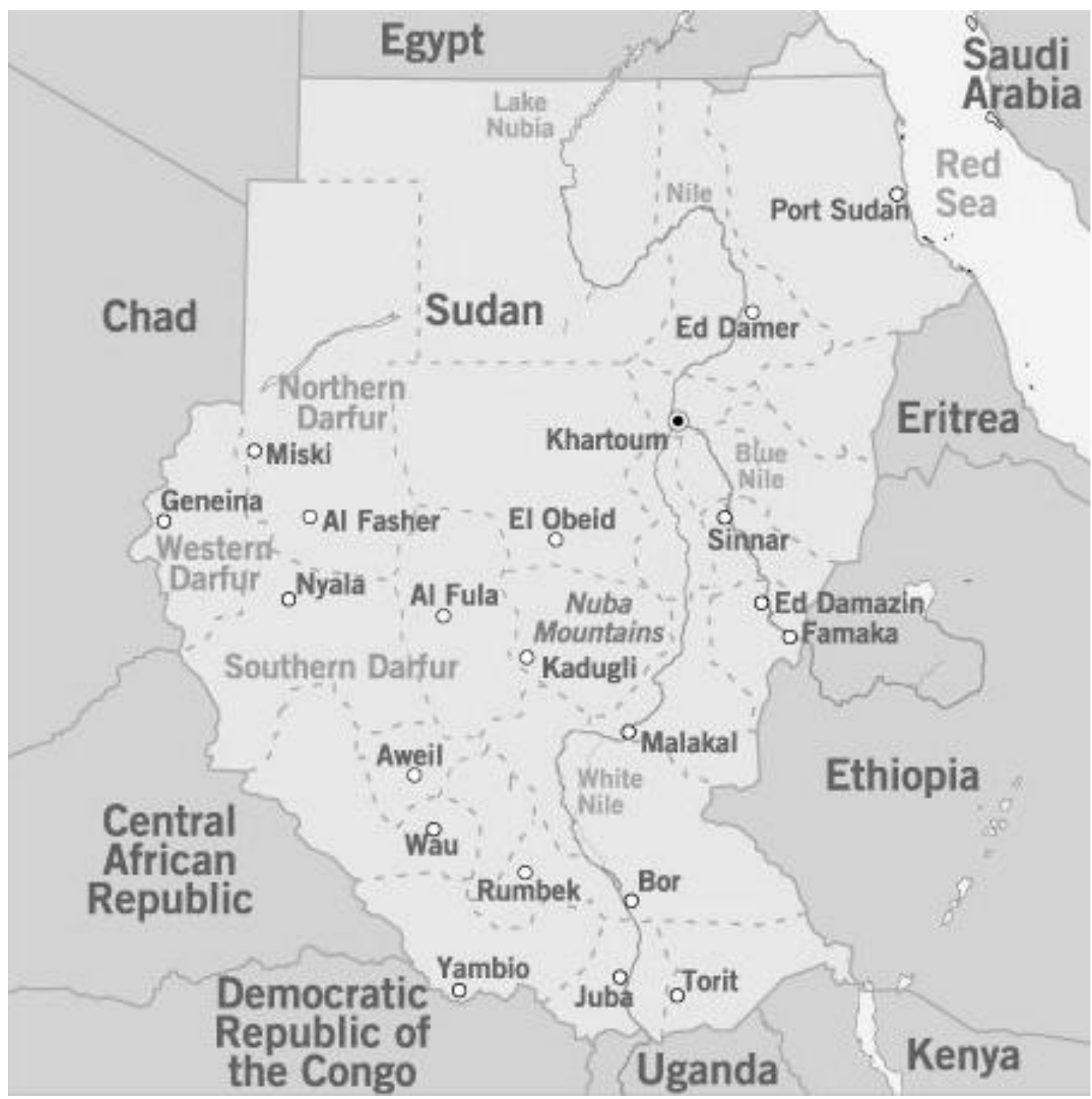

Map: Sudan

Courtesy International Crisis Group 


\section{MAP 2}

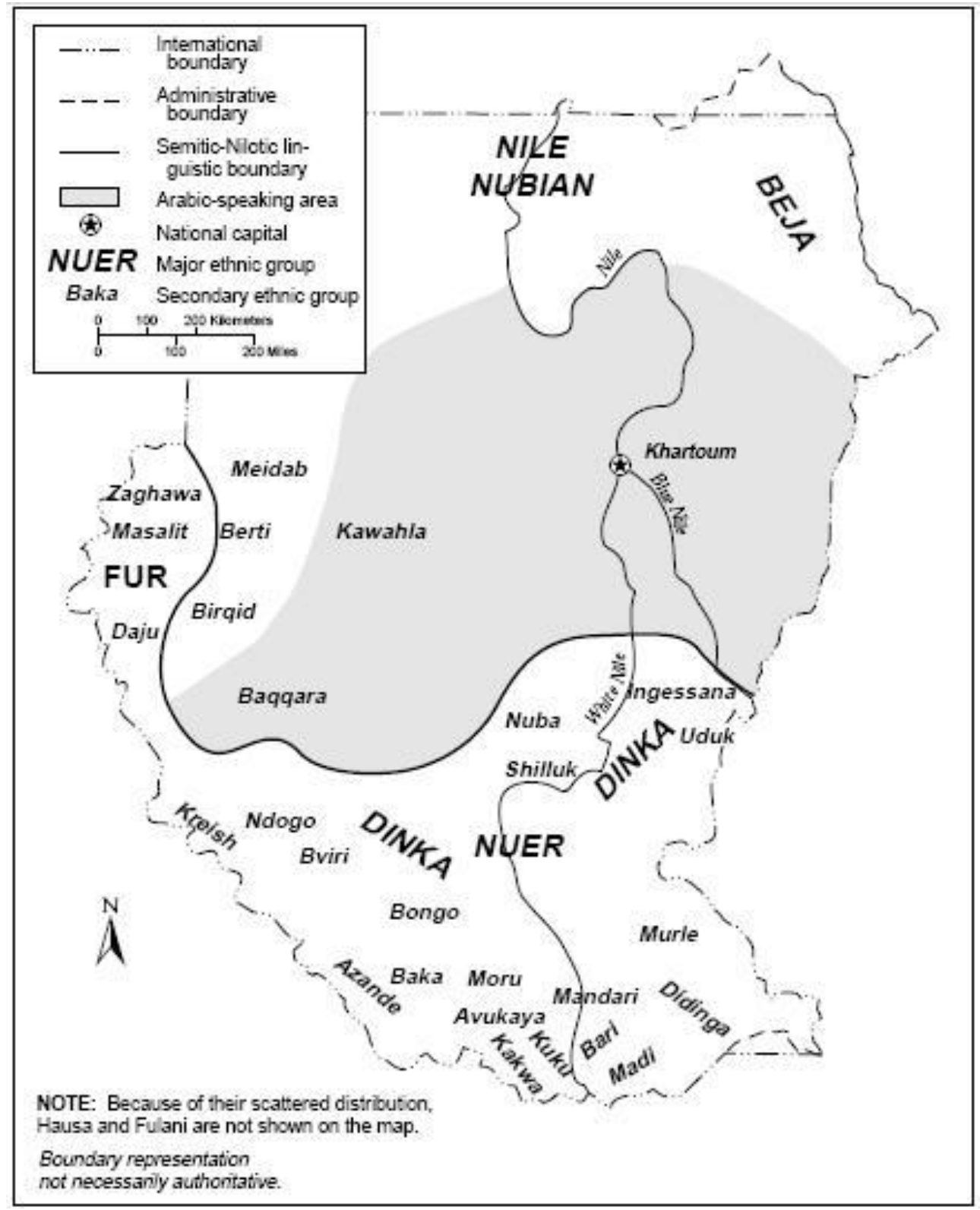

Ethno-linguistic map of Sudan

Courtesy Library of Congress, Geography and Map Division 


\section{CONTENTS}

ABSTRACT

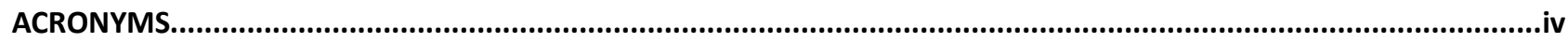

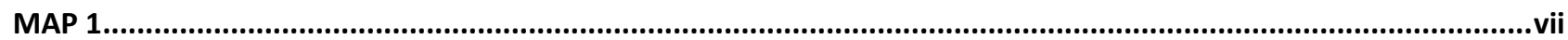

MAP 2

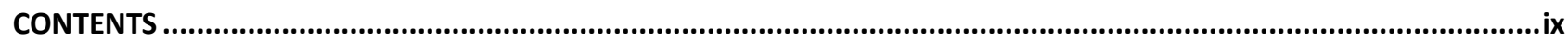

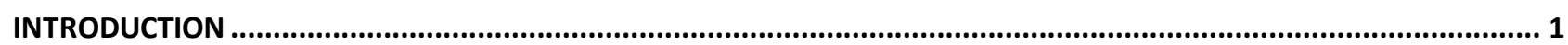

RESEARCH STRATEGY

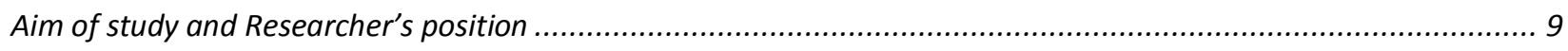

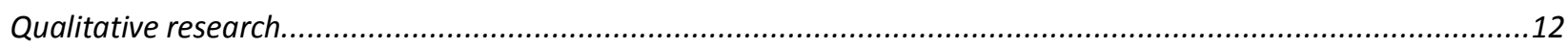

Survey

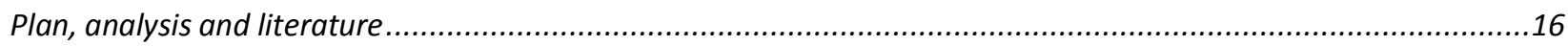

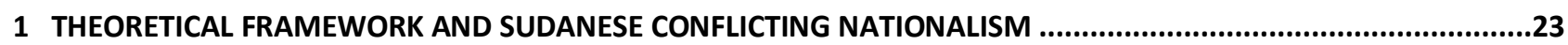

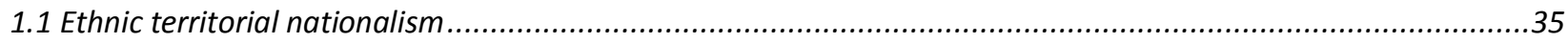

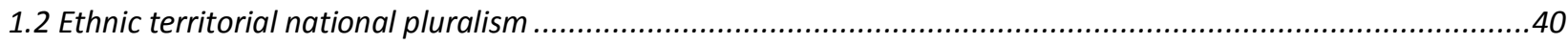

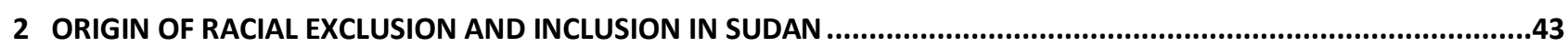

2.1 Project of Canal Jonglei and interpretations of its objectives .....................................................................

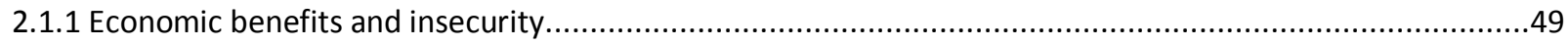

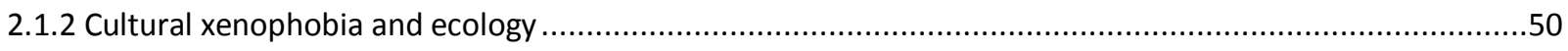

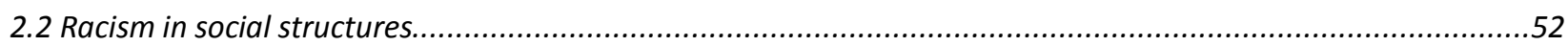

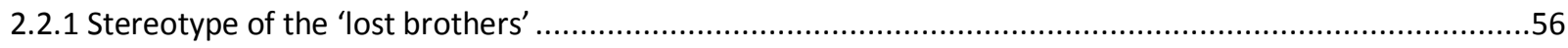

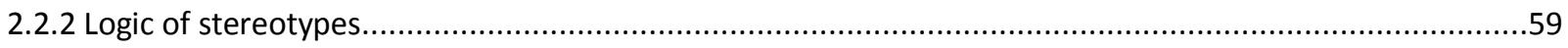

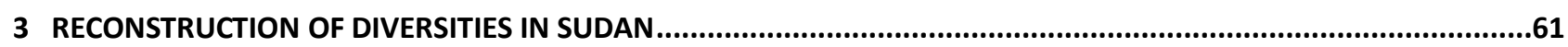

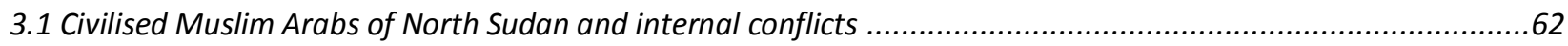

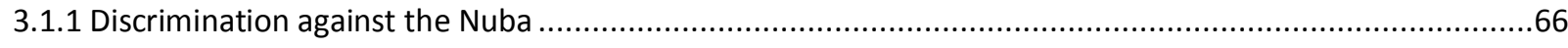

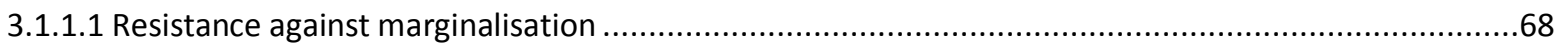


3.1.1.2 Innocence of Islam and Conflict between the Church and the Government ...................................70

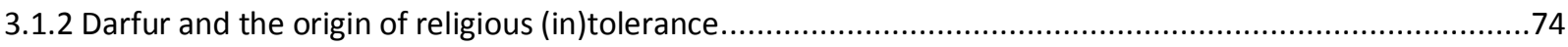

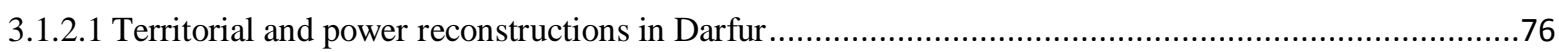

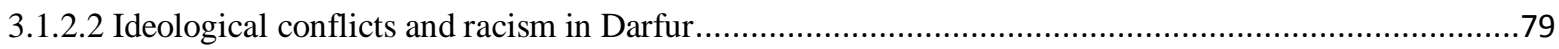

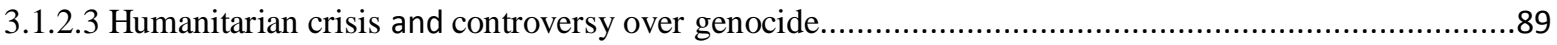

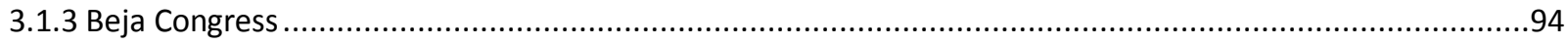

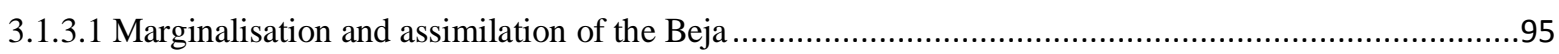

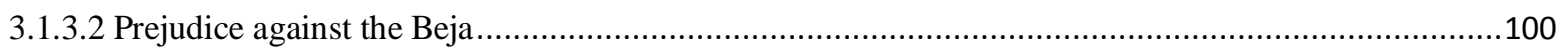

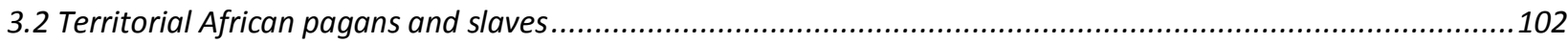

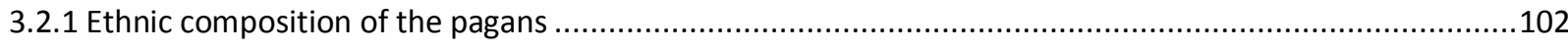

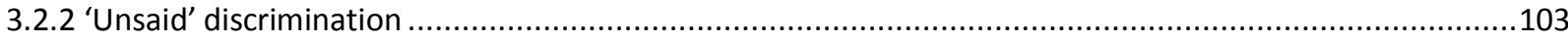

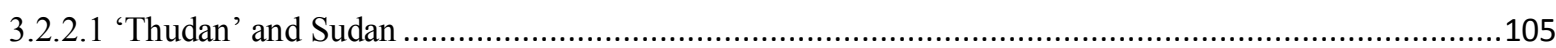

3.2.2.2 Promises of equality and federal system........................................................................ 112

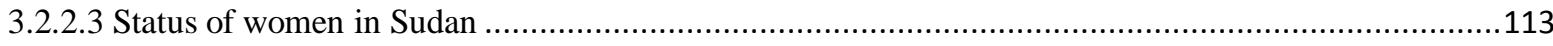

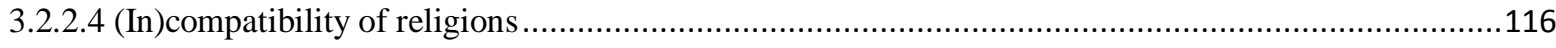

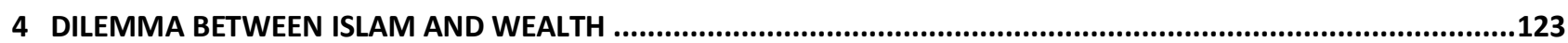

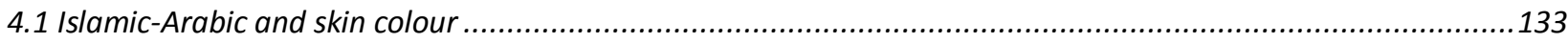

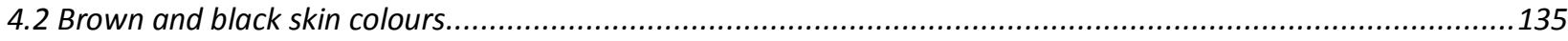

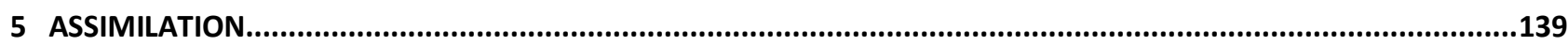

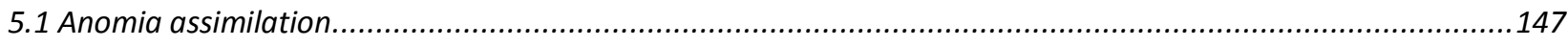

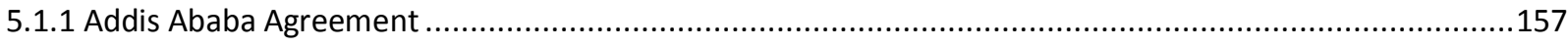

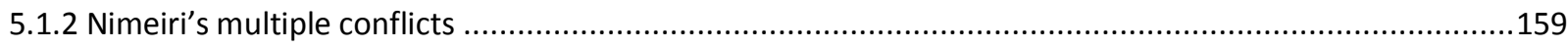

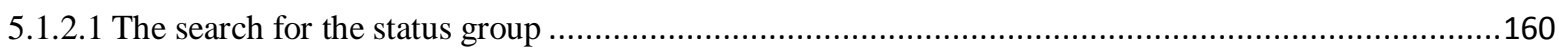

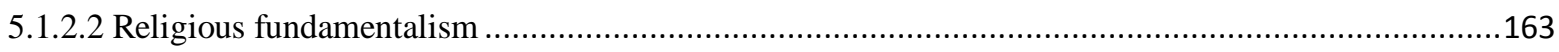

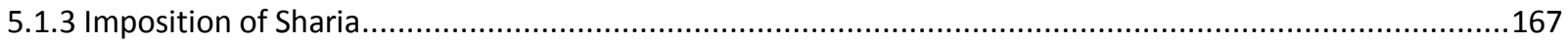

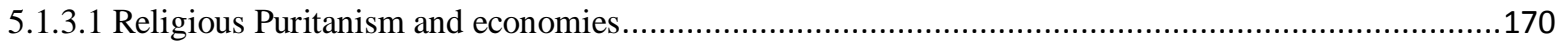

5.1.3.2 Arguments on the hudud punishment ............................................................................. 173

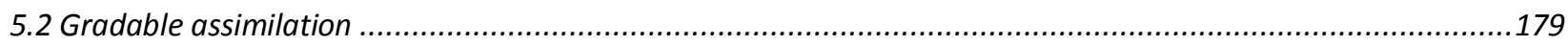

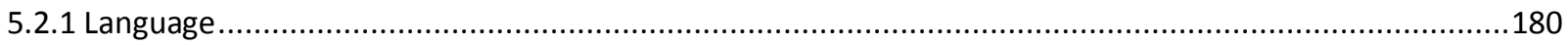

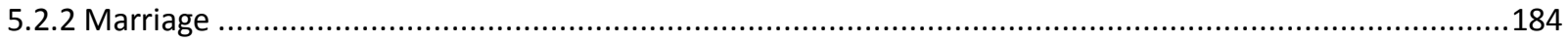

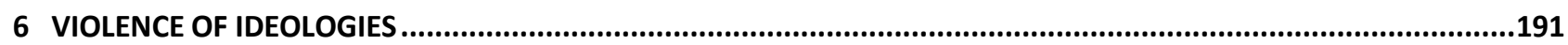

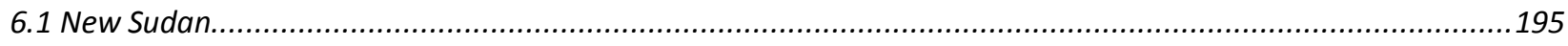

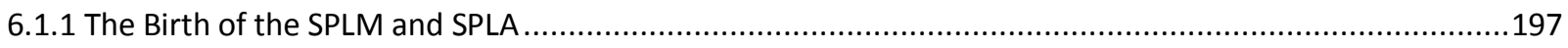

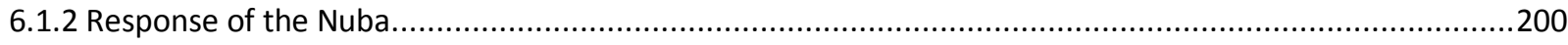




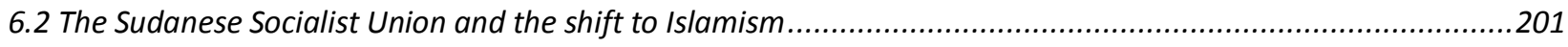

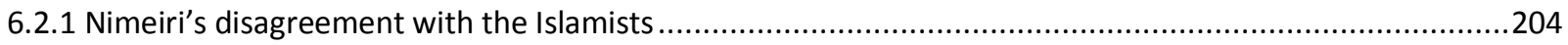

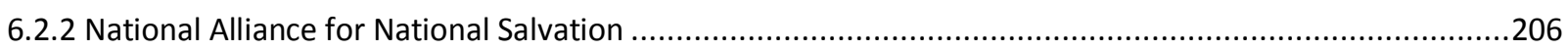

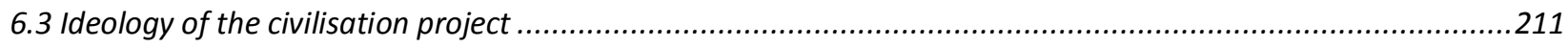

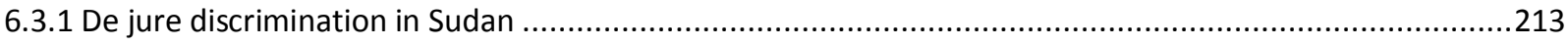

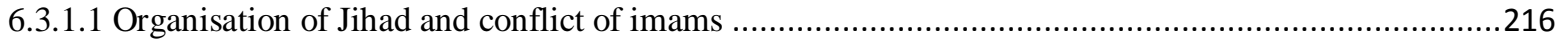

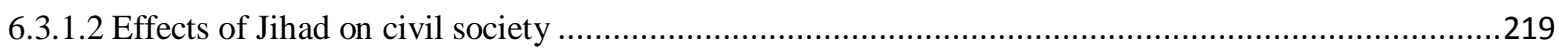

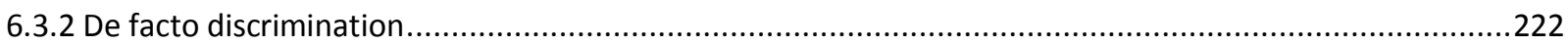

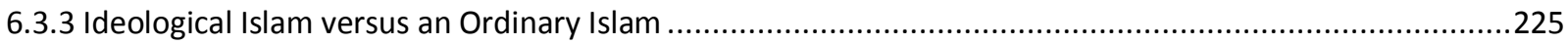

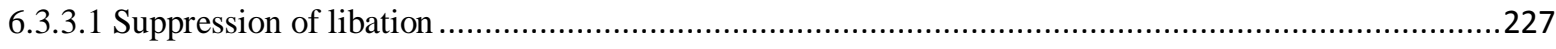

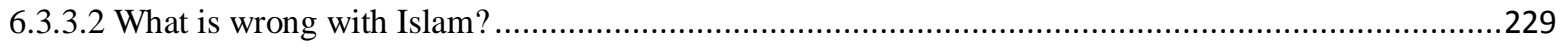

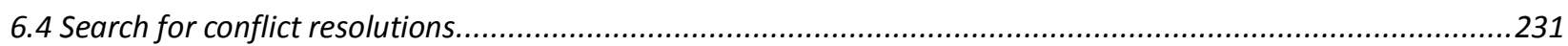

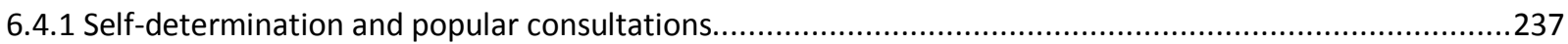

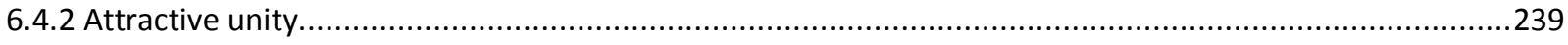

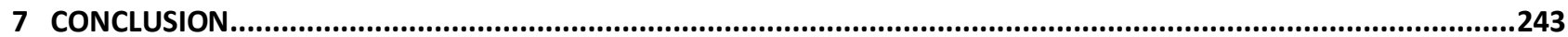

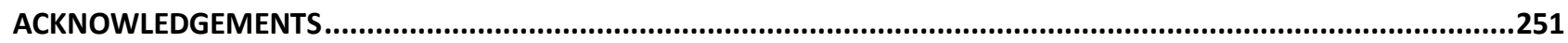

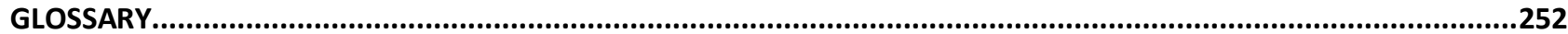

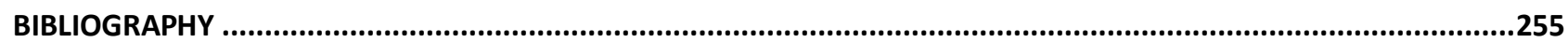

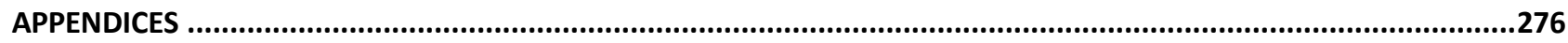

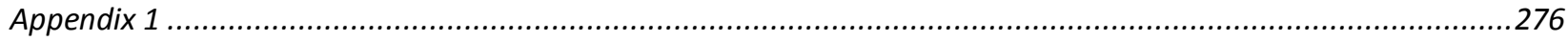

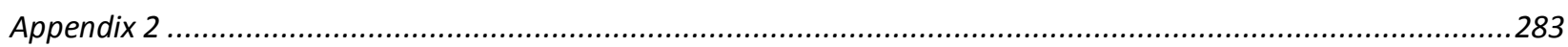

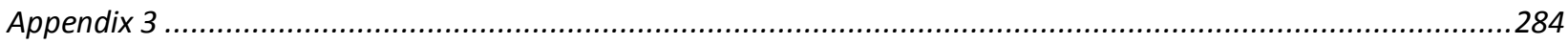




\section{INTRODUCTION}

Sudan remains an unstable state with cycles of ruthless civil wars ${ }^{1}$ that devastate its infrastructure ${ }^{2}$, threaten its territorial integrity ${ }^{3}$, flaw its economic growth and engender woeful humanitarian destitution $^{4}$ and catastrophes. ${ }^{5}$ The objectives of these wars emanate from religious, economic and cultural settings. In the Northern Sudan, the Islamic religion is associated with the Arabic language, culture and race, due to its association with the Middle East. On the other hand, the concerns of the population of the South consist of economic deprivation of its region, limited participation in power sharing and the systematic threats to its Christian, Animist and African cultural identity. ${ }^{6}$

This research explores how decision-makers in Sudan address these complex objectives in a national constitution for the citizens. Since, 1958 to present day, major political parties in Sudan fail several times to reach a consensus to legislate a unified constitutional system. The Islamic political parties of Umma with its sect, Ansar, Democratic Unionist Party (DUP) with its al-Khatimyyia sect and the National Islamic Front (NIF), which has rifted into the National Congress Party (NCP) and currently leads by the President Omer Hassan Ahmed Al-Bashir and the Popular Congress Party (PCP), under the leadership of Hassan Abdullah Turabi all from the North of Sudan urge the adoption of Sharia, (Islamic law) to be a source of legislation and Arabic an official language in a national constitution ${ }^{7}$ On the other hand, the political parties of secular Muslims from Nuba Mountains and 'Christian Animist' of the South, especially the Sudan People's Liberation Movement (SPLM) with its military wing, the Sudan People's Liberation Army (SPLA) support the

\footnotetext{
${ }^{1}$ Johnson, Douglas Hamilton. "The Sudan People's liberation Army \& the Problem of Factionalism" in Christopher Clamham (ed.) (1998). African Guerrillas, Bloomington: Indiana University Press, pp. 60-61. Civil violence in Sudan started in 1955 and ended in 1972 and resumed in 1983.

${ }^{2}$ Leopold, Mark (2005). Inside West Nile, Violence, History \& Representation on an African Frontier, Oxford: James Currey p. 23. Heavy tank tracks of the SPLA towards Yei in South Sudan chewed the tarmac road of Arua and the Government of Sudan long range artillery shelled the town of Koboko.

${ }^{3}$ The Machakos Protocol signed between the SPLM and the Government of Sudan in 2003, p. 8. Machakos provides self determination to the people of Southern Sudan to choose between separation and unity with Sudan.

${ }^{4}$ Prunier, Gerard (2007). Darfur the Ambiguous Genocide, London: Hurst \& Company, p. 54.

${ }^{5}$ Meyer, Gabriel (20059). War and Faith in Sudan, Michigan: William B. Eerdmans Publishing Company, p. 25. A report published by the US Committee for Refugees states that over all the Sudanese war-related death toll for those years is more than 2.5 million.

${ }^{6}$ Iyob, Ruth and Khadiagala, Gilbert M (2007). Sudan the Elusive Quest for Peace, London: Lynne Rienner Publishers, p. 178. The Northern Sudan monopolises power, wealth including oil that is mostly produced from the South and strives to assimilate the African population of the country into the Islamic Arab image.

${ }^{7}$ Prunier, Gerard op. cit., President Al-Bashir heads the National Congress Party and Turabi heads the Popular Congress, p. 84.
} 
legislation of religious and ethnic diversities which must be derived from the diverse set of customary laws. $^{8}$ (See appendix 3 for more information about the historical background of this conflict). 'Islamic fundamentalism' is an ideology, which claims that a just society must base its constitution on Sharia. National laws for such a society are derived from three sources: Holy Quran, Hadith refers to all examples of the Prophet Muhammed and the precedents, which the recognised Islamic scholars interpret in consensus. ${ }^{9}$ The followers of Animism, however, believe that the social structure of society is compatible with powers, which live in natural phenomena, such as animals, trees, mountains and rivers. These beings affect people for both good and bad, but believers refrain from recognising them as God, and hence, they are not worshiped, but respected. ${ }^{10}$

There is no consensus among scholars over what term best describes these beliefs in Sudan. Some call them 'Animism' and others call them traditional or 'theistic' religions. For instance, Nikkel defines the Dinka ethnic group of South Sudan, as followers of "Powers" "11 An-Na'im describes them as mainly Animists ${ }^{12}$ and Johnson rejects all these descriptions defining them as 'pejorative' and asserts that the population in the South adheres to "theistic religions." 13

With all the platitude and pejorative descriptions to the term Animist, this study adopts it, because its definition best suits with the existing religious practices in South Sudan ${ }^{14}$, Nuba Mountains ${ }^{15}$ and Darfur ${ }^{16}$ and it argues that such diversity of religious beliefs constitutes the essence of identity and the institutions created after independence of Sudan from Great Britain on 1 January 1956, have neglected to incorporate it into a national constitution of the state. Muslim scholar ${ }^{17} \mathrm{~T}$ Abdou Maliqalim Simone points out that the legislative power in Sudan does not represent the prevailing

\footnotetext{
${ }^{8}$ Deng, Francis Mading (1995). War of Visions Conflict of Identities in the Sudan, Washington D.C: Brookings Institution, p. 21.

${ }^{9}$ Brown, Daniel (1996). Rethinking Tradition in Modern Islamic Thought, Cambridge: Cambridge University Press, pp. $1-3$.

${ }^{10}$ Voll, John Obert and Voll, Sarah Potts (1985). The Sudan, Unity and Diversity in Multicultural State, London:

Boulder Co., pp. 22-3.

${ }^{11}$ Nikkel, Marc R (2001). Dinka Christianity the Origin and Development of Christianity among the Dinka of Sudan with Special Reference to the Song of Dinka Christians, Nairobi: Paulines Publications Africa, p. 20.

${ }^{12}$ An-Na'im, Abdullahi Ahmed (ed.) (1993). Proselytization and Communal Self- Determination in Africa, New York: Maryknoll, p. 12.

${ }^{13}$ Johnson, Douglas Hamilton (2003). The Root Causes of Sudan's Civil Wars, Oxford: James Currey, p. xviii.

${ }^{14}$ Evans-Pritchard, Evans (1940). The Nuer a Description of the Modes of Livelihood and Political Institutions of a Nilotic Peoples, Oxford: Oxford University Press, p. 46.

${ }^{15}$ Meyer, Gabriel (2005). War and Faith in Sudan, Micchigan: William B. Eerdmans Publishing Compnay, p.67.

${ }^{16}$ Kebbede, Girma (1999). Sudan's Predicament Civil War, Displacement and Ecological Degradation, Aldershot: Ashgate, p. p. 4.

${ }^{17}$ Simone, T Abdou Maliqalim (1994). In Whose Image? Political Islam and Urban Practices in Sudan, Chicago: The University of Chicago Press, p. 24. Simone states "I was sent to Sudan as a Muslim academic".
} 
religious and cultural diversity in national institutions. It aims to transform the whole country towards one religious character based on Islam. For instance, in September 1983, the former President Ja'afer Muhammad Nimeiri imposed Sharia that applies hudud, a formal legal code that stones to death a married woman proved guilty of adultery, amputates cross limbs of a thief found guilty of stealing and whips any person found drinking alcohol. Simone concludes that such a law proves 'unpopular' and intensifies the civil violence in the country between its opponents, the Christians and Animists and its advocates, the Muslim fundamentalists. ${ }^{18}$ For Hassan Makki Mohammad, a Sudanese "Islamist" ${ }^{19}$ scholar, introduction of Sharia in national institutions of Sudan is a significant decision. He claims that the Christian missionaries have not given sufficient opportunity to Islamic Arab culture in the South to be legislated as a unifying factor for Sudan's national identity. Mohammad concludes that it is time now to allow Islam to take its course in transforming Sudan's national identity. ${ }^{20}$

Two scholars, however, consider the transformation of Sudan into the Islamic and Arab cultural identity as an exclusion of other parameters of peculiar cultures in the country. First, Abdullahi Ahmed An'Naim, a Sudanese Professor of Islamic Law at Emory University School of Law in Atlanta ${ }^{21}$ argues that the ideological concept of the NIF party, which intends to transform all public institutions of Sudan, towards 'Islamic fundamentalism' is a difficult legislative task to pass without counterforce of a serious resistance from the Christians and the Animists of the South. This group has derived its modern national identity from the secular Christian West. An'Naim concludes that therefore, it is not easy to address the question of a national constitutional system within the status quo of the NIF definition. ${ }^{22}$ Second, Francis Mading Deng, former Professor of Political Science at Johns Hopkins University in Baltimore, Maryland, USA and currently the United Nations (UN) Secretary General Special Advisor on the Prevention of Genocide argues that the adoption of 'Islamic fundamentalism' in Sudan aggravates the crisis of national identity in the country. The SPLM, which is a radical organisation, where the majority of its members are Christians and

\footnotetext{
${ }^{18}$ Op. cit., p. 26.

${ }^{19}$ Middle East (Spring 2003). "Sudanese Muslims, Christians Discuss 'Co-living and a Culture of Peace", the Middle East Council of Churches News Report, Vol. 15, No. 1, p. 3. "Dr. Hassan Makki Mohammad, a Sudanese professor argues that globalisation of culture; politics and economic impoverishment of the marginalised and helpless community have had a disturbing effect on social peace in Sudan".

${ }^{20}$ Mohammad, Hassan Makki (1989). Sudan: The Christian Design, London: Islamic Foundation, p. 76.

${ }^{21}$ An'Naim, Abdullahi Ahmed (Summer 2003). Re-affirming Secularism for Islamic Societies, New. Perspective Quarterly, Vol. 7. An’Naim, a Sudanese Islamic Jurist at Emory University in New York, USA, pp. 1-2.

${ }_{22}^{2}$ An'Naim, Abdullahi Ahmed (ed.) (1999). Proselytization and Communal Self-Determination in Africa, New York: Maryknoll, p. 13.
} 
Animists from the South considers it as assimilation and adopts an unwavering position in resisting it. Deng concludes that the ideological assimilation of 'Arabisation and Islamisation' that favours the Arab religion and culture over the African, religions and cultures in a national constitution of state is the basic issue that causes political crisis between the Arabised Muslims of the North and the African Christians and Animists of the South. ${ }^{23}$

The legislation of 'Arabisation and Islamisation' with intent to unify ethnic and religious diversities in Sudan implies coercion to assimilation of other cultures into Islamism and Arabism. This legal approach does not evolve the essential diverse religious and racial identities of Sudan. Instead, it represents a racial discrimination to the followers of Christianity, Animism and Muslims from the non-Arabs in national institutions of Sudan. Its implementation in public institutions causes inexorable rebellion and resistance from the indigenous non-Arab ethnic groups of Darfur, Beja along the Red Sea, Nuba in Nuba Mountains and South Sudan. According to de Waal, the NIF party endeavours to construct a system that is entirely based on Islam, which is transformed into Arab racism. This racial transformation has caused a departure of some Muslim politicians of the nonArab origin from the NIF such as Daud Bolad from the Fur of Darfur. Bolad served this party, since his student's career and developed consciousness of systematic Muslim-Arabs racial practices against the non-Arabs' Muslims and the non-Muslims in the distribution of power and wealth in the state. At last, he rebelled and joined the SPLM, a radical political organisation largely composed of Christians and Animists from the South, which rejects Islamisation and Arabisation and from there, Bolad promulgated that Islam is not free from the traditional racism of Muslim Arabs in Sudan. ${ }^{24}$

The phenomenon of racial discrimination in Islamic religion to the Muslim Africans and nonMuslim Africans in sharing power and wealth in national institutions in Sudan is the case study for this research. The study is composed of six chapters and a conclusion. The empirical foundation of the research commences at chapter one, where the analysis based on the theoretical framework rejects the claim that the colonial British policy of the 'Closed District Ordinance' of 1922 is the essential cause of the successive civil wars in Sudan. During that time, the colonial power prevented Muslim Arabs from entering the South, unless a visitor first obtained a permit from the colonial authority. The study argues that the civil violence in Sudan is a conflict of dynamic discrimination and racism based on the inter-independent ideological 'Arabisation and Islamisation' of Sudan's

\footnotetext{
${ }^{23}$ Deng, Francis Mading (1995). War of Visions Conflict of Identities in the Sudan, Brookings Institution: Washington: D C, p. 12

${ }^{24}$ de Waal, Alex (2004). Islamism and Its Enemies in Horn of Africa, Addis Ababa: Shama Books, p. 98.
} 
national structures. This ideology discriminates against the assimilated non-Arabs to Islam equally with the non-Muslims in favour of Muslim Arabs in the distribution of power and national wealth. Thus, the victims of discrimination collectively resort to violence as a form of resistance. The research adopts the theory of Benedict Anderson of 'imagined community' as an alternative model in explaining the diverse religious and ethnic composition of Sudan. This theory helps the diverse religious and ethnic groups of Sudan to imagine themselves in the way they think of themselves. In this chapter, the emergence of two conflicting ideological schools of thought among the decisionmakers in Sudan is plausibly discussed. The first school is the Islamic ideological one and its adherents are defined as ethnic territorial nationalists and the second is the secularist school and its adherents are labeled as ethnic territorial national pluralists. The former asserts un-wavering position for the adoption of Sharia and Arabic as fundamental sources of laws for a national constitution. The latter places a perpetual resistance against these sources and urges the adoption of a secular constitution free from religious canon law and Sharia.

Chapter two shows that the present ideological schools were initially established at the first setting of Sudan, under the basis of social and political inclusion and exclusion. The current pluralists' populations in South Sudan, Nuba Mountains and Darfur at the west were excluded from building the national institutions of state. Successive powers from the nationalist ideological school constructed these regions as economic sources, where slaves were accessed. This phenomenon has built mistrust between the centre and the periphery populations and makes it impossible to reach a consensus in common economic plan for the state, except for the racial stereotype of the 'lost brothers'. The school of ethnic territorial nationalism mainly from the centre of Sudan labels the non-Muslims in the South of Sudan as 'lost brothers', because of their resistance to Islam and they remain largely Animists and Christians, until today, and for this reason, the nationalists described them as 'lost' people on the way to heaven.

Chapter three provides the historical continuity of racial categories of the construction of Sudan into 'Islamic Arab North Region' and the African 'Pagans and Slaves' of the South. Power applied intertwined Islam and Arab as a model of making ethnic and religious uniformity. Under this circumstance, the regions of the African Muslims of the Nuba Mountains, Darfur and Beja, centre far north and east became the 'Northern Sudan of Muslim Arab Region' to the exclusion of the Christian and Animist South. Currently, this unified region is experiencing political fragmentation. The non-Arabs' Muslim regions rebelled, under the allegation that the nationalists' school in dominant of power discriminates against them in religion, Islam. It drops Islam as an inclusive model in distribution of power and wealth and applies race, Arab as an alternative. At present, the 
region is undergoing a series of racial divisions leading to the current deadly and unsettled violence in the vast region of Darfur.

Nonetheless, the chapter discusses further discrimination as new opinions urge the change of the territorial name Sudan to Thudan emerge from the majority of the Nilotic-speaking community from the South. The Nilotic students argue that the name Sudan represents discrimination, since its origin comes from the Arabic word, 'black', a perpetual downtrodden slave in the classical ideological interpretation of the Muslim Arabs. Others claim that, it promotes an assimilation to the model of Arabisation, since the initial ' $\mathrm{S}$ ' in 'Sudan' is a missing sound in their environmental linguistic forms.

Chapter four deals with the dilemmas of Muslim Arabs in South Sudan between the wealth derived from trafficking in the native populations as slaves and the conversion of these Animists to the Islamic religion. Alternatively, Muslim Arabs chose to become slavers, rather than, missionaries to propagate Islam to convert the non-Muslim natives in the South to Islam. They chose so, because conversion would have emancipated the Animists from slavery bondage, because Islam sanctions enslavement of a Muslim by another Muslim. Such experiences of the past interactions have only created a wrong image of Islam, and hence, the Animists remain aggressive to the Islamic religion, until the present time.

Chapter five focuses on the attempt of the adherents of ethnic territorial nationalism to impose the model of assimilation on these resisting non-Muslims and non-Arabs into Islam through a unified national constitution, where its laws are derived from Sharia and Arab language. The group, however, has already adopted Christianity and Animism as its religions and radically urges the adoption of secular laws. At this juncture, the objective dichotomy between the ideological discourses of these schools develops parallel and in turn, the Islamic group in power resorts to 'anomia' assimilation, while its opponents, the secularists urge for the 'gradable' assimilation. The former is referred to a form of an assimilation that totally eradicates cultural, ethnic and religious differences and inserts Islamic uniformity through different methods, including legal ones and violence against the dissidents. The latter is an assimilation that does not remove fully the existing diversity; instead, it makes it possible for the ethnic Muslim Africans, the Animist Africans and the Christian Africans to live in the country with the Muslim Arabs and Christians, where each group takes a 'gradable' culture of another. In comparative study of 'gradable antonyms', the opposite of big is not necessarily to be small, it can be medium. In this context, the assimilation of the nonMuslims to the Islamic culture does not necessarily reflect a complete assimilation, instead a free 
interaction of non-Muslims with Muslims at the public spaces allow each one to take a part of cultural identity from the other.

Chapter six discusses the climax of this assimilation between the two schools of thought leading to the armed violence and the production of new political ideologies of 'New Sudan' and tawajha al-hathari (orientation project). New Sudan is an ideological ideal that aims to transform Sudan towards secularism in opposition to tawajha al-hathari strives to transform Sudan's national identity into a monolithic Islamic identity. Adherents of both ideologies tried to find alternative resolutions to their opposing ideologies and signed the 'Comprehensive Peace Agreement' (CPA) in Naivasha, Kenya in January 2005.

The agreement, however, divided the territorial state of Sudan into two parts. The Northern jurisdiction applies Sharia in civil and criminal judiciaries and the Southern jurisdiction applies secular laws derived from customs in its judiciary system. The agreement also includes an internationally supervised referendum for the people of South Sudan to decide between unity with the North or separation in January 2011. The CPA also grants 'Popular Consultation to the regions of the Nuba Mountains and the Southern Blue Nile known as Ingessana Hill in which the elected legislature decides the appropriate system for their regions. The CPA does not address the prevailing violence in Darfur region; however, the findings at the conclusion indicate that Islam has been adopted for political objective of constructing a majority population in Sudan, which became the unified 'North Sudan of Arab Muslims'. This political practice has changed the religion to a political ideology, where its adherents pursue violence in the name of religion against their opponents, the moderate Muslims, the Christians and the Animists from the marginal areas of the Nuba Mountains, the Ingessana Hill and South Sudan. Muslims' opposition to the adoption of this model are categorised as murtadeen (apostates) and many of them have been killed in the name of Jihad. The adoption of Jihad against Muslim opposition has aroused different interpretations among the divided Sudanese imams (Islamic clerics). Those who allied with the current government in power approved the organised attacks against the opposition in the name of Jihad. On the other hand, those who allied with the opposition(s) reject it and remain in opposition to the government at the marginal populace.

Currently, Jihad which was used as a justification for war in the South, Nuba Mountains and Ingessana Hill has been suspended in the violence waging on in Darfur, instead, racism surfaces between Arab Muslims, janjaweed fighting against the other non-Arab Muslims in the region. The war has escalated and claimed, unknown figure of the death toll. The United Nations (UN) agencies, however, have estimated that more than ten thousands members of the indigenous ethnic 
groups have lost their lives, since the starting of the violence in February 2003 and more than four million have been displaced. Such numbers are difficult to prove, but the fundamental reality is that the violence has affected the people at all socio-economic aspects causing humanitarian disaster which the United States of America (USA), the International Criminal Court (ICC) and the indigenous people of Darfur themselves label as 'genocide'. 


\section{RESEARCH STRATEGY}

Lock et al. observe that "every graduate student who is tempted to employ a qualitative design should confront one question, 'Why do I want to do ... study?' and then answer it honestly". ${ }^{25}$ The search for an honest answer is a challenge for a researcher. It dictates him or her to clarify the purpose of a study. In the view of Maxwell, there are three aims for doing a study: personal, practical and research. Personal purpose refers to the issue which leads a researcher to decide to research on a specific topic. It could be a political agenda with intent to change a political situation or a need to advance an academic career. Practical purpose refers to the accomplishment of some administrative policy-making for an administrative change. Research focuses on understanding something by gaining insights on a certain ongoing issue and why it is occurring. ${ }^{26}$

The aim of this study is both 'personal' and 'research' in general. It is personal, since it is intended for gaining an academic degree and it is a 'research', since it aims to explore and gain insights on political and religious crises in national institutions of Sudan. It seeks to understand why these crises are happening and what alternative(s) are conceptualised by the people in Sudan that could be brought about in order to cease these religious and political conflicts in the country.

\section{Aim of study and Researcher's position}

The purpose of this study is thus, to examine the contested issue of national identity for the diverse ethnic and religious groups in Sudan in a scientific viewpoint. Researching in a scientific way creates also a position for a researcher. It shows his or her identity whether he or she is a modernist/positivist, postmodernist or a pragmatist. Modernists/positivists believe that scientific knowledge can unfold the universal truths for the common good of the universal institutions. ${ }^{27}$ On the other hand, postmodernists argue that scientific knowledge of modernity, which has been largely constructed on the binary oppositions of true and false, mind and body, reason and emotion is mostly unstable, since it embodies ideological discourses. ${ }^{28}$ Therefore, there is no guarantee that "freedom and democracy" would constitute better society. ${ }^{29}$

\footnotetext{
${ }^{25}$ Locke L Spirduso et al. (1993). Proposals that Work (3rd ed.), Newbury Park: CA: Sage, p. 107.

${ }^{26}$ Maxwell, Joseph A (1996). Qualitative Research Design an Interactive approach, London: Sage Publications, p. 15.

${ }^{27}$ Smith, Philip (2001). Cultural Theory an Introduction, New York: Blackwell Publishers p. 235.

${ }^{28}$ See Lemert, Charles, (1997). Social Things: An Introduction to the Sociological Life, New York: Rowman and Littlefield, p. 101. Harding, Sandra (1986). The Science Question in Feminism, New York: Cornell University Press,
} 
Conflict between the modernists and postmodernists compel some scholars to urge the adoption of 'pragmatism' as an alternative resolution theory for it. For instance, Rorty suggests that social scientists should drop both modernist and postmodernist theories and adopt pragmatism, which is a theory that urges institutions to adhere to "what works". ${ }^{30}$

It is through this scientific conflict of the modernists/positivists, postmodernists and pragmatists, where the position of the author becomes visible in the text. The researcher follows "the positivist ideal of objective and disinterested scientist" that adheres to the research question in analysing the collected data. ${ }^{31}$ The author believes that impartial analysis of the heterogeneous institutions such as of Sudan reveals the hidden truth that positively contributes for the improvement of these institutions in a worthy scientific manner. ${ }^{32}$ Working for the 'common good' spontaneously makes this researcher to be classified as a positivist/modernist. It transforms him to become an advocate of universal ethical values, which promote the establishment of institutions on the basis of democraticmulti-party system with an obligation to respect human rights of individuals in Sudan. In its theoretical meaning, human rights originated from individual rights as "gifts" from natural laws. ${ }^{33}$ The Prosecutor of the International Criminal Court (ICC) has accused Omer Hassan Al-Bashir the current President of Sudan of three counts of genocide against the indigenous African Muslim ethnic groups in Darfur: "genocide by killing (article 6-a), genocide by causing serious bodily or mental harm (article 6-b) and genocide by deliberately inflicting on each target group conditions of life calculated to bring about the group's physical destruction (article 6-c)". ${ }^{34}$

In the opinion of this writer, national institutions in Sudan can function towards political perfection for the realisation of common good, if decision-leaders separate religion(s) from national

pp. 243, 245. Seidman, Steven (1991). The End of Sociological Theory: The Postmodern Hope, Sociological Theory, American Sociological Association, Vol. 9, No. 2, p. 68.

${ }^{29}$ Bass, Alan (tran. and ed.) Jacques Derrida (1987) Writing and Difference, Chicago: Chicago University Press, p. 280.

${ }^{30}$ Rorty, Richard (1989). Contingency, Irony and Solidarity, Cambridge: Cambridge University Press, pp. 51-52.

${ }^{31}$ Maxwell, Joseph A (1996). Qualitative Research Design an Interactive approach, London: Sage Publications, p. 15.

${ }^{32}$ Smith, Philip (2001). Cultural Theory an Introduction, New York: Blackwell Publishers, p. 235. For positivists, scientific knowledge and experts can uncover truth that can be used for the common good of institutions.

${ }^{33}$ Langley, Winston E (1992). Human Rights Sixty Major Instruments, North Carolina: McFarland \& Inc Publishers, p. 21.

${ }^{34}$ International Criminal Court, http://www.icccpi.int/menus/icc/situations\%20and\%20cases/situations/situation\%20icc\%200205/related\%20cases/icc02050109/icc020 50109?lan=en-GB The Prosecutor of the International Criminal Court (ICC), Luis Moreno Ocampo has accused President of Sudan Omer Hassan Al-Bashir of three counts of genocide: "genocide by killing (article 6-a), genocide by causing serious bodily or mental harm (article 6-b) and genocide by deliberately inflicting on each target group conditions of life calculated to bring about the group's physical destruction (article 6-c)" against the indigenous African Muslim ethnic groups in Darfur. 
constitutional system and adopt non-religious laws within the system of democratic pluralism. ${ }^{35}$ 'Representative democracy' cannot observe standard of human rights, when it derives its civil and criminal laws from religious codes and dogmas. In April 2010, Sudan revived representative democracy based on the system of multi-party pluralism; yet, the system mostly relies on the religious laws, which do not sufficiently adhere to moral standard of universal human rights obligations. ${ }^{36}$ For instance, under Sharia in Sudan, a person who has been confirmed of theft at a highway faces amputation of limbs and women found guilty of adultery are stoned to death. ${ }^{37}$ For Held, "representative democracy", which is mostly adopted in modern state(s) is inadequate and so, it "requires clarification" of its constitutional laws and the procedures of their application. ${ }^{38}$

The modern world has been effectively improving its institutions to better form; however, exploitation of religion in politics disrupts the positivists/modernists hope for the development of public institutions in a peaceful manner. ${ }^{39}$ Setting it in the mosques, synagogues and churches as an issue for individuals and leaving public aim to a scientific engagement creates a hope for the prosperous world, but postmodernists' scholarships continue to mislead the world. For instance, Lemert claims that: "Postmodernism, if it is about anything, is about the prospect that the promises of the modern age are no longer believable because there is evidence that for the vast majority of people ... there is no realistic reason to vest hope in any version of the idea that the world is good and getting better. ${ }^{40}$ Researching on these issues dictates a researcher to choose between qualitative and quantitative research methods.

\footnotetext{
${ }^{35}$ Smith, Philip (2001). Cultural Theory an Introduction, New York: Blackwell Publishers, p. 235. During the Enlightenment, attacks were launched in the name of science on religion.

${ }^{36}$ Clapham, Andrew "United Nations Charter-Based Protection of Human Rights" in Catarina Krause and Martin Scheinin (2009). International Protection of Human Rights, a Textbook, Åbo: Åbo Akademi University, p. 79.

${ }^{37}$ Iyob, Ruth and Khadiagala, Gilbert M (2007). Sudan the Elusive Quest for Peace, London: Lynne Rienner Publishers, p. 32. The Theocratic state which arose in 1989 with its Islamic ideology utilizes and manipulates all Islamic religious tenets to "justify the killings of Muslims by Muslims".

${ }^{38}$ Held, David (1995). Democracy and the Global Order from the Modern State to Cosmopolitan Governance, Oxford: Polity Press, p. 23.

${ }^{39}$ Sidahmed, Abdel Salam and Ehteshami, Anourshiravan (eds.) (1996). Islamic Fundamentalism, Oxford: Westview Press, p. 179. The Muslim fundamentalists of the NIF in Sudan captured the democratically elected government and transformed the people of Sudan into the culture of its Islamic theocracy. See Nye, Malory (2003). Religion the Basics, London: Routledge, p. 177. The forces of modernism, which separate religion from politics and insert secular laws, have successfully made religion to decline in the Western world in favour of reason. The twenty-first century, however, is being disrupted "by religion", which has been used by Al-Qaeda network to attack New York and Washington on 11 September 2001.

${ }^{40}$ Lemert, Charles, (1997). Social Things: An Introduction to the Sociological Life, New York: Rowman and Littlefield, p. xii.
} 


\section{Qualitative research}

Hatch observes that, when an advanced graduate student decides to conduct a scientific research, one question comes into his or her mind is that "Should I do qualitative study?"41 The reason is that such student may claim that quantitative research is statistical and experimental; therefore, its strengths are mainly conceptual, while a qualitative research method engages the participants, which is an action that may be virtually opposed in most orientations of quantitative research method. $^{42}$

Under these guidelines, this research adopts a qualitative rather than a quantitative method in order to engage the participants. Calhoun argues that, when there is an issue of difference the alternative is to involve "poly-phonic discourse, not a monological statement ... a discourse in which many voices shed light on a problem from different vantage points". ${ }^{43}$ Since 1958 to present day, the 'monological' political force in Sudan has failed to reach a consensus on how to manage the religiously, ethnically and racially heterogeneous identities in a unified constitution for Sudan as a nation-state. Therefore, the author decided to involve students from some Sudanese universities in order to elicit such a 'poly-phonic discourse', instead of the constant 'monological' discourse of political force on the issue of identity in the country. In modern society, students of higher institutions of learning are important groups. They are the future leaders of states and capable of constructing political and cultural ideologies for their political aims. For instance, students of higher institutions of learning in Sudan organised and implemented the popular uprisings which overthrew the former military juntas of Ibrahim Abboud in October 1964 and Ja'afer Muhammad Nimeiri in April 1985. Hassan Abdullah Turabi, the founder of the NIF constantly appeals to students to move and overthrow the current Government of Sudan (GoS), under the President Omer Hassan AlBashir party the NCP. Turabi says history proves that students in Sudan have a political capacity to overthrow dictatorial military regimes. ${ }^{44}$

Considering these past successes and contributions of students in participating in politics stimulates political and democratic associations in Sudan to enter into campuses of universities and recruit students for

\footnotetext{
${ }^{41}$ Hatch, J Amos (2002). Doing Qualitative Research in Education Settings, New York: State University of New York Press, p. 1.

42 Ibid.

${ }^{43}$ Calhuon, Craig (1995). Critical Social Theory: Culture, History, and the Challenge of Difference (Twentieth-Century Social Theory, New Jersey: Wiley Blackwell, p. 88.

${ }^{44}$ Shreq al-Awsat (2007, March 17). "Fatwa Jadida min Turabi: Rejim el-Zina Sharia Yhudia, The New Islamic Verdict: For Turabi, Stoning Is a Judaism Law”, Arabic Newspaper, Shreq al-Awsat, No. 10336, p. 1.
} 
their political parties. This paradigm turns the higher institutions in Sudan into massive centres of political competition, where the political associations acquire members for their political parties. Nonetheless, the author is conscious that students of higher education have their distinctive political organisations, yet some of them have no stable political parties, still the aim of the study is to make students generate their views, opinions, imaginations and concepts about their identities. The search for their opinions and ideas requires research strategy. Hedrick et al. suggest that in order for a researcher to ensure research accuracy and ethics, he or she needs to construct clear strategies for collecting information. These strategies include, reviewing the relevant literature and conducting data gathering that involves visit(s) to the field of the problem. ${ }^{45}$ This research study has adopted these strategies as:

\section{Survey}

One of the methods in collecting research data is a survey, but it faces its own philosophically, technically and politically based criticisms. Politically, Marsh argues that survey method is manipulative in two ways. First, the knowledge it produces about institutions gives power to elite in control and this situation may lead to an abuse of power. Second, it cannot produce knowledge about reality, but only ideological reflections which could be embraced by some interest group. ${ }^{46}$ Technique based criticism is that survey method is too statistical and that reduces interesting questions to totally incomprehensible numbers, while many studies are not necessarily statistical. Second, it relies on highly structured questionnaires which are restricted and limited. ${ }^{47}$ Philosophical critics maintain that a survey research searches on particular people's beliefs and actions and neglects the context in which these beliefs and actions occur. Therefore, when an issue of research is taken out of context, it is easy for a researcher to mis-understand the meaning of behaviour. ${ }^{48}$ This research project rejects some critical views against the survey method in two ways: First, survey method produces complex perceptions, opinions, ideas, and imaginations of people about themselves in certain political, social and cultural surroundings. Their produced opinions from these surroundings constitute authentic data for relatively objective analysis. According to Fowler, survey is the only method, where a researcher can provide numerous facts about people's behaviours and attitudes at different situations. A researcher applies it "by asking a sample of people about themselves" on specific questions such as on race, religion, age, household

\footnotetext{
${ }^{45}$ Hedrick, Terry E et al. (1993). Applied Research Design a Practical Guide, London: Sage Publication, p. 16.

${ }^{46}$ Marsh, Catherine (1982). The Survey Method: the Contribution of Surveys to Sociological Explanation, London: George Allen and Unwin.

${ }^{47}$ de Vause, D A (1987). Surveys in Social Research, London: George Allen \& Unwin, p. 8.

${ }^{48}$ Mills, C Wright (1959). The Sociological Imagination, Oxford: Oxford University Press, p. 140.
} 
structure, education, housing, financial incomes and the way of spending these incomes. ${ }^{49}$ Second, survey is an inclusive technical research method. It is not only limited on the construction of questionnaires, but goes beyond. In the view of de Vause, a survey is not a particular technique of collecting information that is only based on questionnaires, but it involves other appropriate techniques and mechanisms such as interviews, observation, and content analysis. ${ }^{50}$

These complex research techniques are very significant and valuable, and therefore, they are adopted in this research. Fowler defines the questionnaire as a structured technique of data collection, whereby its respondents are asked with the same set of question(s) as variable(s). Thus, in 'descriptive research', the fundamental art of designing the questionnaires is connected with the research objective(s) or question(s) a researcher wants to answer. It should be composed of dependent and independent variables to be measured. Independent variable refers to the cause of change and dependent variable refers to the effect. On the other hand, de Vause maintains that apart from variables, it is useful for a researcher conducting an 'explanatory research' to consider the background in setting the questionnaires. The background measure refers to the characteristics such as sex, race, religion, ethnic group, education, social status, occupation, region and age. ${ }^{51}$ This study is both descriptive and explanatory. The former refers to "what is going on" and the latter deals with "why it is going on". 52 And in order to describe 'what is going on' about the conflict of national identity and 'why it is going on' in Sudan, it adopts a survey as one of its fundamental strategies. Its main primary source material was collected in a survey conducted in the fieldwork in Sudan. Questionnaires written in English and Arabic were structured taking into consideration relevant background to the study. Age was omitted in the structure, because it is not culturally acceptable to ask a person about his or her age in Sudan. Generally, the age of the university students in Sudan is between seventeen to twenty five years. Regions and religions in Sudan were the independent variables used in the questionnaires with their subsequent dependent variables. The reason for these two variables was to allow students from different regions of Sudan with their different religious backgrounds express their views towards the main question of study. (See appendix 1)

Having structured the questionnaires, the necessity of limiting the participants on the process came up. A researcher should seriously take into consideration the question "How many

\footnotetext{
${ }^{49}$ Fowler, Jr Floyd J (1984). Survey Research Method, London: Sage Publications, p. 10.

${ }^{50}$ de Vause, D A (19826). Surveys in Social Research, London: George Allen and Unwin, p. 70.

${ }^{51}$ de Vause, D A (19826). Surveys in Social Research, London: George Allen and Unwin, p. 71.

${ }^{52}$ Op. cit. p. 11.
} 
participants does one need to study in order to address the goals that one has set?"53 The questionnaires were presented to five hundred students of higher education in Sudan. The study takes students as an example ${ }^{54}$ of the target population of the study. This number was divided among the Muslims, the Christians and the Animists. Three-hundred and fifty were Muslims and one hundred and fifty were Christians and Animists. There were objective reasons for this imbalanced division among the adherents of the three religions. First, the population of Muslims in Sudan is larger than the population of the Christians and the Animists. ${ }^{55}$ Second, it is said that some Christians of the South, Darfur and Nuba Mountains practice compatibly Christianity and Animism, and those were adequate reasons to combine them into one group. ${ }^{56}$

After this organisation, how to gain access to students in order to deliver the questionnaires became the challenging key issue for the researcher. Stouthamer-Loeber and van Kammen maintain that it is necessary for a researcher conducting a fieldwork research to ask for the cooperation of the related agencies such as hospitals, schools, churches or courts in order to reach the target participants for study. ${ }^{57}$ Cooperation with professors and lecturers was initiated in order to reach students hence; the questionnaires were distributed to students in the lectures halls. The author was allowed to come into class-rooms, during lectures and seminars and to ask the Animist, the Christian and the Muslim students to voluntarily fill the questionnaires. Under this method, University of Khartoum was given two hundred, University of Juba received one hundred and fifty and Omdurman Ahlia University got ninety. Both University of Bahr el-Ghazal and University of Upper Nile were given sixty, where each received thirty.

There were some fundamental reasons for the choice of the five universities. First, University of Khartoum is very popular as the oldest and largest institution of higher education in Sudan. Second, Omdurman Ahlia University is an elite institution that sets its curriculum and orientation at the

\footnotetext{
${ }^{53}$ Stouthamer-Loeber, Magda and van Kammen, Welmoet (1996). Data Collection and Management a Practical Guide, London: Sage Publications, p. 15.

${ }^{54}$ Mangione, Thomas W (1995) Mail Surveys Improving the Quality, London: Sage Publications, p. 38. Survey research based on non-random involves convent and quota samples. The first refers to the easily accessible group and the latter refers to the targeting equal numbers such as males and females.

${ }^{55}$ Hughes, John (1996, September 26). "Removing the Veil of Slavery and Exploitation", Christian Science Monitor, Vol. 88, Issue 212, p. 19. Sudan is the largest country in Africa. Its northern part is inhabited by the Muslim majority, while the South embraces the Christian and Animist minority.

${ }^{56}$ de Waal Alex (2006, December 22). "Averting Genocide in the Nuba Mountains, Sudan", p. 2. The inhabitants of the Nuba Mountains are the same as the people of South Sudan. They are indigenous Black Africans. Some adhere to Christianity, Islam and Animism compatibly.

${ }^{57}$ Stouthamer-Loeber, Magda and van Kammen, Welmoet (1996). Data Collection and Management a Practical Guide, London: Sage Publications, p. 8.
} 
campus on secular values. For this reason, it has been in conflict with the present Government of Sudan leading to several clashes between the ideological Islamic students and the ideological secular Muslim, Animist and Christian students. In 1996, the students from the Islamic forum incinerated offices, libraries and other essential properties of the University. The same scenario was repeated in 2004, when some administrative offices were burnt. These systematic events at one university compel the author to consider it as the centre of conflicting ideologies of 'Islamic fundamentalism' and secularism and hence, it deserves research attention. Moreover, the author has extensive experiences at these three universities. First, he was an undergraduate student at Omdurman Ahlia University and graduate student at University of Khartoum and taught at both universities from 1997-2000. These connections made it possible for him to establish cooperation with teaching staff and students. Hedrick et al. argue that "Even totally open and visible setting usually require some degree of authorization for data collection". ${ }^{58}$ On one occasion, the author authorised two students in the lecture hall at the University of Khartoum to collect the responses from other students in the hall and deliver them to him in the office at the university campus. Colleagues from the staff provided comfortable office spaces for writing, interviewing and receiving the responses of the research questionnaires from students.

University of Juba was chosen, because it is the oldest university in the South and it embraces most students from the 'Southern Region'. The University of Bahr el-Ghazal was chosen for three reasons. First, the researcher has been a member of the teaching staff, since, November 1997, when its campus was temporary transferred to Khartoum, during the political turmoil of violence from its original campus in Wau, South Sudan. Second, Wau is also the home town of the author and that has helped him in getting accommodation and interacting with students. Third, it is the centre of the largest ethnic group in South Sudan, the Dinka; thus, most of its students come from two Nilotic ethnic groups, the Dinka and the Jur Col. University of Upper Nile was chosen, because it has been the centre of four Nilotic ethnic groups: the Nuer; the Dinka; the Shilluk and Anyuak. The majority of its students come from these Nilotic ethnic groups.

\section{Plan, analysis and literature}

The implementation of the research process also requires a schedule or a framed time. StouthamerLoeber and van Kammen recommend that a researcher dealing with study that depends on access to

\footnotetext{
${ }^{58}$ Hedrick, Terry E et al. (1993). Applied Research Design a Practical Guide, London: Sage Publication, p. 96.
} 
participants from specific organisation(s) needs to take an appropriate time for it. ${ }^{59}$ The plan for the survey and the collection of data from five universities in Sudan was framed due to the limited time at hand. It was comprised of three visits of intensive three-month-fieldwork- periods. The first survey was conducted from January through March 2007 and the second starting from January to March 2008. During this time, a complete number of four hundred and fifty seven filled questionnaires by students were returned to the author. One hundred and eighty one responses were from the University of Khartoum, one hundred and thirty nine from the University of Juba, seventy seven from Omdurman Ahlia University, thirty from the University of Bahr el-Ghazal and thirty from the University of Upper Nile. (See table 1)

Having the filled questionnaires, then it was possible to begin the analysis. Scholars pursue different methods of analysis for a qualitative research. For instance, LeCampte and Preissele pursue 'typological' analysis. They describe it as a method of "dividing everything observed into groups or categories on the basis of some canon for disaggregating the whole phenomenon under study". ${ }^{60}$ Hatch, however, limits it into nine steps. First, identification of data to be analysed; second, reading of the data and marking entries related to the research typologies. Third, reading of entries by typology and recording the main ideas in entries on a summery sheet; forth, looking for the patterns, relationships, themes within the typologies. Fifth, reading data and coding entries according to patterns identified and keeping a record of what entries go with which elements of patterns; sixth, decide, if these patterns are supported by data. Seventh, looking for the relationships among the identified patterns, eighth, writing the patterns as one-sentence generalisations and finally, selecting the data excerpts that support generalisation. ${ }^{61}$ There is also an inductive analysis, which Potter, defines as a search for patterns of meaning from the collected data, so that general statements about phenomena, under research investigation are produced. It commences with the examination of particular issues within the data by "looking for patterns across individual observations ... arguing for those patterns as having the status of general explanatory statements". 62 Third, there is an interpretive analysis, which Hatch defines as a systematic search for meaning and

\footnotetext{
${ }^{59}$ Stouthamer-Loeber, Magda and van Kammen, Welmoet (1996). Data Collection and Management a Practical Guide, London: Sage Publications, p. 21.

${ }^{60}$ LeCompte, Magarete D and Preissle, Judith (1993). Ethnography and Qualitative Design in Educational Research $\left(2^{\text {nd }}\right.$ ed.), San Diego CA: Academic Press, p. 257.

${ }^{61}$ Hatch, J Amos (2002). Doing Qualitative Research in Education Settings, New York: State University of New York Press, p. 153.

${ }^{62}$ Potter, W J (1996). An Analysis of Thinking and Research about Qualitative Methods, Mahwah, NJ: Lawrence Erlbaum, p. 151.
} 
giving meaning to data. It is about making sense of social situations by making explanations for what is going on within them. Fundamentally, it is about making inferences, developing insights, attaching significance, identifying themes, discovering relationships, developing explanations, making interpretations, mounting critiques, generating theories and drawing conclusions. ${ }^{63}$

It seems there is no strict difference between typology and interpretive analyses; however, Denzin asserts that interpretive analysis helps in identifying "different definitions of the problem" by showing how individuals interpret public policies in public institutions, which have been established to settle certain problem(s). ${ }^{64}$ This formed the basis for this study to adopt interpretive and typology-research methods in analysing the responses of students to the questionnaires. It identifies different imaginations and definitions of students to the problem of Sudan's national identity within the responses and discovers their relationships, attaches relevance, develops explanations, contrasts opposing opinions, generates supporting theories to the explanations, compares new imaginations with the existing literature, mounts critiques on what does not fall within the universal standard of human rights obligations and finally draws general conclusion.

During the third visit to Sudan, the author emphasised the right to religion as a constructed right derived from individual freedom. ${ }^{65}$ In this visit, September to November 2008, method of interview was introduced. For Kvale, a qualitative research interview is a mutual conversation lasting at least one hour between two people about a specific theme that a researcher presents to an interviewee. Its purpose is to comprehensively understand the views and experiences of an interviewee on a subject in question in order to "develop knowledge about one specific" issue. ${ }^{66}$

In light of this view, interviews were constructed in accordance to the responses of some students to the questionnaires. In essence, they were intended for certain specific respondents in order to obtain more knowledge about some particular issues which appeared in their answers to the questionnaires. In another word, the reason for the interview was to give further opportunities to these students to explain deeper what was not clear in their earlier responses in the questionnaires

\footnotetext{
${ }^{63}$ Hatch, J Amos (2002). Doing Qualitative Research in Education Settings, New York: State University of New York Press, p. 180.

${ }^{64}$ Denzin, Norman K (1989). Interpretive Interactionism, Applied Social Research Methods Series Vol. 16, Newbury Park: Sage Publications, p. 10-11.

${ }^{65}$ See Heywood, Andrew (2003). Political Ideologies an Introduction (3rd ed.), Hampshire: Palgrave Macmillan, p. 30. Hilgard, Ernest R (1962). Introduction to Psychology ( $3^{\text {rd }}$ ed.), New York: Harcourt, Brace \& World, Inc., p. 69. Human being is created free as a fetus, develops and moves within the mother's womb.

${ }^{66}$ Kvale, Steinar (1996). Interviews an Introduction to Qualitative Research Interviewing, London: Sage Publications, pp. 36,98 .
} 
and so focusing on their past responses. During the interview, the author avoided anything that would have influenced an interviewee, but remained impartial. ${ }^{67}$ (See appendix 2). Sixty seven of them were individually consulted for private interviews for one hour per each student in specific locations. Denzin urges researchers to locate an appropriate interactional space for an interview within a limited time. ${ }^{68}$ The cooperation that the researcher received from the teaching staff at the five universities made this possible. Each student was interviewed in her or his respective university environment. Three students were interviewed individually in the office given to the author at the University of Khartoum. Four were individually interviewed in the office at Omdurman Ahlia University. Thirty students were individually interviewed in the office at the University of Juba. Fifteen were individually interviewed in the office at the University of Bahr el-Ghazal and fifteen in the same manner were interviewed in the office at the campus of the University of Upper Nile.

After these interviews, came the final review of relevant scientific literature, impartial interpretation of the data and all necessary crosschecking of students' statements and observations. Therefore, the present manuscript is organised in accordance to the responses of students to the given questionnaires, participant observation and the interviews, however, it is necessary to elaborate what participant observation means in this particular context. It does not refer to the traditional 'participant observation' conducted by ethnographers such as Bronislaw Malinowski, Margaret Mead and Radcliffe-Brown who spent most of their time studying their subjects. ${ }^{69}$ Such an approach is unnecessary for the present study, but applied to a limited extent, complementing data gained from the questionnaires and interviews as the author is already an insider with vast knowledge of culture(s), experiences and observed behaviours in Sudan. Therefore, participant observation becomes here a sort of observation which Hatch defines as a process of getting closer to the subjects of study in order to add more definitions and descriptions of their activities to the already existed experiences about them. ${ }^{70}$ Such experiences and knowledge of the author to cultural characteristics helped him to describe and interpret more impartially and unbiased some activities which the students performed, during the fieldwork in Sudan. For instance, the author observed that

\footnotetext{
${ }^{67}$ Smith, Philip (2001). Cultural Theory an Introduction, New York: Blackwell Publishers, p. 234. For the modernists, it is an obligatory for a researcher to apply a theory of a free value system.

${ }^{68}$ Denzin, K Norman (1989). Interpretive Interactionism, Applied Social Research Methods Series Vol. 16, Newbury: Sage Publication, p. 66.

${ }^{69}$ Rosaldo, Renato (1989). Culture and Truth: The Remaking of Social Analysis, Boston: Beacon, p. 30.

${ }^{70}$ Hatch, J Amos (2002). Doing Qualitative Research in Education Settings, New York: State University of New York Press, p. 72.
} 
the majority of African Muslim students from Nuba Mountains, Darfur, often walked with the African Christian-Animist-students from the South, while it was very rare to witness a MuslimArab student walking with a Christian-Animist from the South. This new association of the African Muslims with the African Christians reflects the dynamic change of the political setting of social institutions in the country, where religion is not necessarily any longer a model of social relationship in spaces, but racial categories of 'Africans' and 'Arabs'.

Among the relevant literature, studies of Ann Mosely Lesch, Francis Mading Deng, Douglas Hamilton Johnson, Abdullahi Ahmed An'Naim, Alex de Waal, Robert O Collins and Abdel-Wahab El-Affendi have been very helpful sources. Sociological studies of Robert Miles, Emile Durkheim, Max Weber, Thomas Humphrey Marshall, Zygmunt Bauman, Stephen Steinberg, Anthony Smith, Michael Omi, Howard Winant, Robert Ezra Park and Eric Hobsbawm have also been useful for the study. Nonetheless, writing of conflict issues in current Sudan is not easy, because of political harassment, interrogation, detention and murder of those who disseminate knowledge that does not match to the policy of the ruling government, the NCP. A Sudanese who attempts to disseminate an opinion that deviates from the oriented policy of tawajha alhathari may be killed. ${ }^{71}$ Authorities can quickly interpret any critical views as "blasphemy"72 or "apostasy", which are both punishable to death in the criminal court of Sharia. ${ }^{73}$

The incrimination of citizens in expressing their political opinions in Sudan puts the writer into a dilemma between omitting and publicising the names of his respondents. Omission of the names of the respondents puts the author in a conflict with a large number of students. Generally, every student knew the purpose of the questionnaires and the interviews and the majority of them urged the researcher to publish their names in the text. On the other hand, listing their names within the text might still jeopardise them. A solution to this dilemma was found from two scholars. First, Fowler Jr urges researchers to protect research respondents by removing their names from the text

\footnotetext{
${ }^{71}$ Amnesty International (2007, October). "Editor-in Chief of Al-Wafaq Arabic Newspaper, Muhammad Taha Is Killed", p. 1. Before his death, the government had charged him with apostasy. He published an article in his newspaper that discusses the genealogy of the Prophet Muhammad. Later on 6 September 2007, Taha was found dead on the street in Khartoum with a decapitated body and his head placed beside his body. His killing appeared to be politically motivated.

${ }^{72}$ Shreq al-Awsat (2007, December 22). "Government of Sudan Punishes the British Teacher, Gillian Gibbon”, Shreq al-Awsad English Newspaper, Issue No. 10617, p. 1. The government of Sudan accuses the British school teacher, Gillian Gibbon of "blasphemy" in naming the teddy bear Muhammed.

${ }^{73}$ Sudani (2007, December 3). "Hokuma Sudania Hakim aala Messereen, Government of Sudan Sentenced Egyptians", Sudani Arabic Newspaper, Issue No. 757, p. 2. Two Egyptian nationals, Ali Al-Fatah Abdel Ra'wuof and Mahruoz Muhammed Abdel Gadier were accused of "apostasy" and sentenced to six months imprisonment, because they sold a book that carries controversial views about Islam.
} 
and inserting ambiguous names for their identifications. ${ }^{74}$ Second, Hatch argues that ethics obligates a researcher in any organisations to consider the impact of research work "on the wider social and physical environment". ${ }^{75}$ Ethical perspective made the author consider the safety of the responded students as a priority. For this reason, pseudo names were constructed for them. The names are defined in the footnotes and some within the text of the manuscript in terms of religious, ethnic, university and regions as requested in the questionnaires. The term anonymous was also used for the identification of those who have not revealed their names in the questionnaires. The majority of students from the Nilotic peoples of Jur Col, Anyuak, Jieng (Dinka), Naath (Nuer) and Collo (Shilluk) identify themselves Christians and Animists and some defined their religious identity as 'Christian-Animists'.

The systematic use of the religious compatible definition has forced the author to conclude that there is a difference between the descriptions, 'Christian-Animist' and 'Christian and Animist'. The former refers to the Nilotic students that practice compatibly Christianity and Animism and the latter identifies the believers who adhere to only one of the two religions, either Christianity or Animism in Sudan. Furthermore, the capitalised 'North' stands for the region of the Northern Sudan and a student from that region is also identified as a 'Northerner'. This definition actually includes the west, far north; the east and the centre of the country. The rest falls under the category of the 'South' and 'Southerner'. Every critical qualitative and quantitative scientific research requires a theory which conforms to the main question of a research problem. In many occasions, lack of a relevant theoretical framework for a scientific research causes problems of coherence, specially, when a researcher transfers the oral data into a body of a text. ${ }^{76}$ Thus, Alexander defines theory as a generalisation of separate issues from particulars of separate and concrete cases. ${ }^{77}$

\footnotetext{
${ }^{74}$ Fowler, Jr Floyd J (1984). Survey Research Method, London: Sage Publications, pp. 136-137.

${ }^{75}$ Hatch, Mary Jo (2006). Organisation Theory, Modern, Symbolic, Postmodern Perspectives, Oxford: Oxford University Press, p. 95.

7676 Kvale, Steinar (1996). Interviews an Introduction to Qualitative Research Interviewing, London: Sage Publications, p. 10.

77 Alexander, C. Jaffery (1987). Sociological Theory since 1945, London: Columbia University Press, p. 23.
} 
Distribution of Questionnaires to five Universities

\begin{tabular}{|l|l|l|}
\hline University & Sent Questionnaires & Responses \\
\hline Khartoum University & 200 & 181 \\
\hline Juba University & 150 & 139 \\
\hline Ahlia University & 90 & 77 \\
\hline Bahr el-Ghazal University & 30 & 30 \\
\hline Upper Nile University & 30 & 30 \\
\hline Total & 500 & 457 \\
\hline
\end{tabular}

Table 1

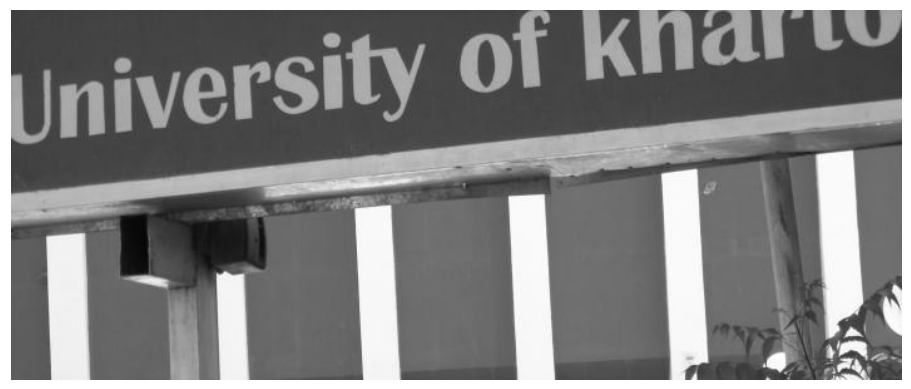

Sharaqa Hall University of Khartoum

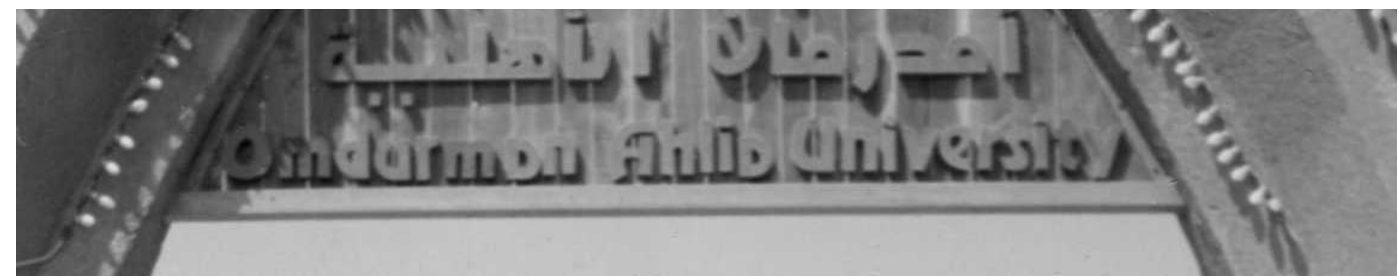

Main Entry to Omdurman Ahlia University 


\section{THEORETICAL FRAMEWORK AND SUDANESE CONFLICTING NATIONALISM}

Researching on the topic of identity is extremely controversial, because of its three conflicting philosophical conceptions. For the Enlightenment, identity is a human-person fully centred as unified individual and sufficiently endowed with reason and conscious action and therefore, the self is an identity of a person. ${ }^{78}$

In contrast, sociological inter-actionists reject this theory and argue that self-personal identity is not entirely sufficient; instead, it is formed in relation to 'significant others' or interaction between self and society. ${ }^{79}$ For the post-modernists, identity is not permanent; it is constantly formed and transformed in relation to the ways a society is represented in cultural institutions. It is not biological, but historical; therefore, contradictory identities at different time of history can construct a comfortable narrative that unifies their identities into a unified one. ${ }^{80}$

Political forces in Sudan have failed to construct a comfortable narrative for the diverse religious and ethnic groups in the state. They have, instead, established racial and discriminatory institutions making the civil violence in Sudan to be fundamentally a conflict of identity based on the dynamics of racism and discrimination within the political, cultural and social institutions of the territory. The research rejects the claim of some scholars that the past and the current civil wars in the country are products of the colonial 'British Policy' of the 'Closed District Ordinance'. For instance, Beshir Muhammed Said claims that the colonial British Government decided to introduce a legal system the 'Closed District Ordinance' since 1922 and effectively implemented it in 1926. The bill treated Southern Sudan, Nuba Mountains, Beja and Darfur separately from the Islamic and Arab North. The intention was to build up a series of self-autonomous racial and tribal systems based on the indigenous customs, traditions and other local beliefs in exclusion of Islam. Muslim Arabs were instructed to first obtain 'Special Permits' in order to enter those areas. Later Darfur, the Nuba

\footnotetext{
${ }^{78}$ Hall, Stuart “The Question of Cultural Identity” in Stuart Hall, et al. (eds.) (1991). Modernity and Its Futures, London: Polity Press in Association with Open University, p.275.

${ }^{79}$ See Badlwin, John D (1996). George Herbert Mead: Unifying Theory for Sociology, California: Sage, pp. 90-91. Morris, Charles W. (ed.) (1934). Mind and Society, Chicago: Chicago Press, p. 175. Miller, David L (1973). George Herbert mead, Self, Language and the world, Chicago: Chicago Press, p. 17.

${ }^{80}$ Hall, Stuart (1987). 'Minimal Selves', in Identity: The Real me, ICA Document 6 London: Institute for Contemporary Arts, p. 12.
} 
Mountains and some Beja areas were dropped from the policy of the closure with the exception of the South. Said concludes that such policy was a firm and direct barrier to the transformation of Sudan into an Islamic and Arab culture and that had created hostilities and frequent violence and wars between the Northern Muslim Arabs and the African Christian culture in Sudan. ${ }^{81}$

In addition, Abdel Wahab El-Affendi also claims that the present violence in Sudan dates back to the imperial government of the British Southern Policy. The main objective of that policy was to stem the expansion of Islam into the Southern territory. Christian missionaries and British officials were politically hostile to the Islamic religion and culture. This policy caused a reaction from the Northern Muslims who swiftly reacted to reaffirm the validity of Islam and Arab culture in the region. Hence, in 1938, the Graduate Congress, an organisation mainly composed of Muslims and Arabs of the North outlined in their memorandum to the British Colonial Administrator, Sir Douglas Newbold the importance of Arabic and Islam in the educational system in the South. ElAffendi concludes that the policy has created a prominent hostility of Muslims from the North to Christianity and the counterforce of resistance from Christian South leading to the present war in the country. ${ }^{82}$

These claims of the two scholars are misleading, since they fail to disclose the genuine cases for the closure. First, the closure was an antidote to the trafficking in ethnic groups from the South. Historically, Sudan emerged as a state, under abrupt interactions between the indigenous Africans and Muslim Arab settlers coming from Egypt and the Arabian Peninsula ${ }^{83}$. The first Arab settlers entered into Sudan with few females and consequently married mostly the indigenous, non-Muslim ethnic Africans. After such exogamous marriage, racism emanated within the institutions between the settlers and the indigenous identities. Deng explains, during that time, there were no barriers to cross marriages between the settled Arabs and the indigenous peoples of Sudan. The indigenous African women in the territory were married to Arab Muslims and their children were identified as Arab Muslims in accordance with the patrilineal system of Arab culture. After these exogamous marriages, a sense of diversity was built, but later social superiority and inferiority arose between

\footnotetext{
${ }^{81}$ Said, Beshir Mohammed (1956). The Sudan Crossroads of Africa, London: The Bodley Head, p. 45.

${ }^{82}$ El-Affendi, Abdel Wahab (1990, July). "Discovering the South: Sudanese Dilemmas for Islam in Africa", African Affairs, the Journal of the Royal African Society, Vol. 891, No. 356, p. 371.

${ }^{83}$ Iyob and Khadiagala op. cit., pp. 45-46. Iyob and Ruth maintain that the long history of Sudan indicates that it came to be as a result of the encounters of umma (Islamic nation) Arabs emerging from the Arabian Peninsula and 'kuffar' (unbelievers) the indigenous African tribes.
} 
them. Muslim Arabs pursued the practice of trafficking in the Black indigenous Africans of Sudan as slaves ${ }^{84}$ and that project dominated the social structures for centuries, until today. ${ }^{85}$

These racial categories of superiority and inferiority, where the former trafficked in the latter could not be impeded without introduction of legal measures preventing it, especially, when slavery was illegalised, and yet, it continued to thrive in the institutions of Sudan. According to Jok, Sudan is a country, "where old habit persists" ${ }^{, 66}$ in its social spheres. For instance, after six decades, when England illegalised the slave trade with all its accompanying inequities, Samuel Baker, a British explorer visited Khartoum, capital city of Sudan in 1862. Baker was astonished to find that the city was economically booming due to the wealth derived from slave trade. Jok concludes that the professional slavers from the Muslim Arab area sneaked into the territories of the South and Nuba Mountains and kidnapped the indigenous Africans for trafficking them in the North and beyond. ${ }^{87}$

This illegal situation gives a satisfaction that the introduction of the 'Closed District Ordinance' was the only alternative left to the British to fetter slavers from entering the South. Its legal adoption had mitigated the enslavement and trafficking in the Animist peoples from the South. According to Lesch, the British legal bill of the 'Closed District Ordinance' which limited the entry of Muslim Arabs to the South had helped the Black Animist population in the South to remain inaccessible by Muslim Arab slavers. ${ }^{88}$

Second, even if the South was not closed for the entry of Muslim Arabs from the North, the indigenous people of the South would have had continued to resist Islamisation, because the relationships between them and Muslim Arabs were in an anomalous state. For example, a cohort of Muslim Arabs enriched themselves on the illegal means of theft and loot essential properties from them. Those attitudes have played a negative role in converting the Animists to Islam. They have created a racial hatred to Arab Muslims leading to the violence of resistance to Islam, until the British introduced the bill of the closure. According to Abel Alier, the indigenous inhabitants of the South remained constantly in resistance to foreign cultures, because, many violent events between them and Muslim Arabs from the North had built the racial territories that left them without mutual

\footnotetext{
${ }^{84}$ Deng, Francis Mading (1978). Africans of Two Worlds the Dinka in Afro-Arab Sudan, New Haven: Yale University Press, p. 12.

${ }^{85}$ Deng, Francis Mading. "Scramble for Souls: Religious Intervention among the Dinka in Sudan" in Abdullahi Ahmed An-Na'im (ed.) (1993). Proselytization and Communal Self Determination in Africa, New York: Maryknoll, p. 194. The enslavement of the Blacks in Sudan goes back to the time Before Christ.

${ }^{86}$ Jok, Madut Jok (2001). War and Slavery in Sudan, Philadelphia: University of Pennsylvania Press, p. 5.

${ }^{87}$ Ibid.

${ }^{88}$ Lesch, Ann Mosely (1998). The Sudan Contested National Identities, London: James Currey, p. 32.
} 
understanding throughout the time of their interactions. The attitudes of Muslim Arabs of plundering property, stealing animals, burning dwellings, trafficking in them as slaves and imposition of alien customs and beliefs into their cultural life acerbated their rejection of the Islamic faith and such practices motivated some British Administrators to prevent Muslim Arabs from entering the Southern territory. ${ }^{89}$

This perspective suggests that the historical legal bill of the 'Closed District Ordinance' has genuine objectives from the past and it is seriously misleading for the above two Sudanese scholars to claim it as the fundamental reason for today's conflict in the territorial Sudan. The present conflict in Sudan is a resistance to the model of 'Arabisation and Islamisation' of public institutions in the country. This political tendency does not represent the diversity of Sudan; instead, it represents the rejection of others. According to Sir Hilton Poynton, the primary objective of the British colonial policy in transfer of power in was summed up in promoting the existing religious diversity in building institutions of state. ${ }^{90}$

In this regard, the policy of 'Arabisation and Islamisation' rejects diversity in nation building. Deng observes that the successive governments in control of power in Sudan are Muslims and identify themselves Arabs. For this reason, they follow the pattern of Islamisation and Arabisation of public institutions as a means to establish national identity. ${ }^{91}$ The intertwined Arabisation and Islamisation model neglects the empirical composition of Sudan's racial and cultural diversity and favours cultural identity of Islam and Arab to the exclusion of the cultures and the customs of the Animists, the Christians and the unique ritual characteristics of the African Muslims in Sudan. Muddathir Abd Al-Rahim, a Sudanese scholar ${ }^{92}$ describes Sudan as a very unique country in Africa. It embraces contradictory racial identities which represent it as "Arab-Africa" 93 with its Islamic African traditions. ${ }^{94}$

\footnotetext{
${ }^{89}$ Alier, Abel. "The Southern Sudan Question" in Dunstan M. Wai (ed.) (1973). The Southern Sudan the Problem of National Integration, London: Frank Cass, p.13.

${ }^{90}$ Poynton, Sir Hilton. "The View from the Colonial Office" in A H M Kirk-Greene (ed.) (1979). Africa in the Colonial Period the Transfer of Power the Colonial Administrator in the Age of Decolonisation, p. 15.

${ }^{91}$ Deng, Francis Mading. "Scramble for Souls Religious Intervention among the Dinka in Sudan" in Abdullahi Ahmed An'Naim (ed.) (1993). Proselytization and Communal Self Determination in Africa, New York: Maryknoll, p. 192.

${ }^{92}$ Wai, Dunstan M (ed.) (1973). The Southern Sudan the Problem of National Integration, London: Frank Cass, p. ix. Wai describes Muddathir Abdel Rahim a Sudanese professor with a PhD from Manchester.

93 Abd Al-Rahim, Muddathir. "Arabism, Africanism, and Self-identification in the Sudan", in Dunstan M. Wai (ed.)

(1973). The Southern Sudan the Problem of National Integration, pp. 29-30, 34

${ }^{94}$ Ibid.
} 
The neglect of power to this diversity of 'Arab-Africa' and its frequent political attempts to transform it into monolithic Islamic-Arab in cultural identity epitomises the paradigm of racism in building of institutions for the citizens of Sudan. Miles and Brown observe that a discriminating power builds institutions on the principle of exclusion to the opposing distinctive culture in national institutions. ${ }^{95}$ The imposed adoption of Islamic and Arabic culture in national institutions represents the exclusion of the presence of the African Muslims, the African Christians and the African Animist in Sudan. Two scholars observe this phenomenon and present their views. First, An'Naim argues that the legalisation of Sharia above other religions and cultures in the national constitution in the Northern Sudan as a main source of legislation as requires in article four (4) of the constitution, places the non-Muslims in an inferior status in their country. ${ }^{96}$ Second, Hassan observes that in Sudan, there is an African Islam in Darfur which is unique and different from the classical Islam of Muslim Arabs at the far north and centre of present Sudan. ${ }^{97}$

These scholarly views prompt the author to argue that the adoption of indispensable Islam with Arab by power as one criterion in making a constitutional system in Sudan implies favour to the Islamic Arab culture and exclusion of other religions, non-Arab races and unique cultures of the African Muslims and non-Muslims in the state and that model constitutes the dynamics of racism and discrimination. In essence, the present populations of Sudan believe that they are different ethnically, culturally and religiously. Despite that belief, they continue to imagine themselves as a nation within the territorial state of Sudan. Benedict Anderson defines nation as an imagined political community that imagines itself inherently limited and sovereign. It is imagined, because "the members of even the smallest nation will never know most of their fellow country members or do not hear of them, yet in the minds of each one lives the image of their communion" ${ }^{\text {"98 }}$ within a territory. ${ }^{99}$ This theory is significantly relevant for the explanation of ethnic and cultural diversities in Sudan. It helps us to understand and expound that the populations living in the current territory of Sudan are of different ethnicities, cultures, religions, traditions and customs, yet they still live in the territory, where they imagine themselves as one people sharing the territorial nation state, Sudan.

\footnotetext{
${ }^{95}$ Miles, Robert and Brown, Malcolm (2004). Racism ( $2^{\text {nd }}$ ed.), London: Routledge Taylor and Francis Group, p. 103.

${ }^{96}$ An'Naim, Abdullahi Ahmed (ed.) (1993). Proselytization and Communal Self Determination in Africa, New York: Maryknoll, p. 112.

${ }^{97}$ Hassan, Gubara Said (2007) .Western Sudan's Darfur Region: Conflict, Humanitarian Crisis and Post Conflict Reconstruction, Helsinki: University of Helsinki Acta Politica, p.30.

${ }^{98}$ Anderson, Benedict (1991). Imagined Communities Reflections on Origins and Spread of Nationalism (rev. ed.), London: Verso, p. 6.

${ }^{99}$ Ibid
} 
Southhall reiterates that the Dinka ethnic group identifies itself as a distinct group known as Munyjieng, Jieng or Munyjiang to mean the people. Again, the ethnic Nuer knows itself as Naath to mean the people and the Shilluk, calls itself as Collo, a term refers to the Black people. Southhall concludes that all three of these ethnic groups are conscious of other groups residing with them in Sudan. ${ }^{100}$ Second, Al-Shahi points out that the people of Sudan recognise two phenomena in their identities. Locally they identify themselves with a tribe as distinct in terms of descent, history, politics, language, religion, music and traditions, yet they feel that they are people of the territorial Sudan. ${ }^{101}$

The research argues that these different communities of Sudan require a quality of political power that prompts their imaginations through a national constitution that conforms to the phenomena of their religious, ethnic and cultural diversities. Under this constitution, power can inculcate into their imaginations a sense of being equal territorial citizens with their diverse cultures, yet they are a territorial nation. Nonetheless, power remains in constant orientation of them, so that each group avoids political statements in media, conferences, seminars and all national institutions that may build negative prejudice and stereotypes affecting the maintenance of these imaginations. According to Lee, Malaysia is a country composed of ethnic Chinese, Indians and indigenous Malays. The Malaysian politicians take this diversity as a base for constructing organs of national institutions. Traditions and customs of these different ethnic groups are the sources for integration of the nation. Extending from 1993-2003, Malaysia had introduced institutional structures which gave to each citizen a political and cultural space. The constitution reflects icons of multiculturalism and nationalism of these diverse ethnic groups. Leaders and civilians that operate within the social and the political circles refrain from releasing statements that may jeopardise this orientation. The power of the media is impressive, since its ethic reflects the image of compatibility of diverse Malaysians. Lee concludes that such a form of equal representation of different ethnic traditions in the national constitution makes a diverse society to believe that it is a nation. ${ }^{102}$

Practically, the theory of imagination that adopts an ethnic territorial pluralistic model as in Malaysia is an antithetical to the theory of ethnic territorial nationalism in Sudan, which favours the

\footnotetext{
${ }^{100}$ Southhall, Aidan (1976, December). "Nuer and Dinka Are People: Ecology, Ethnicity and Logical Possibility, Man, New Series, Vol. 1, No. 4, pp. 463-91.

${ }^{101}$ Al-Shahi, Ahmed. "The Distinctiveness of the Shaiqqiyyia Tribe of Northern Sudan: Complexity and Continuity" in Herve Bleuchot Hopwood (ed.) (1991). Sudan History, Identity, Ideology, Oxford: Ithaca Press, p. 107.

${ }^{102}$ Lee, Raymond L. M. (2004). The Transformation of Race Relations in Malaysia: From Ethnic Discourses to National Imagery 1993-2003, African and Asian Studies, Vol. 3, No. 2, pp. 115-117.
} 
intertwined Islam and Arab culture and rejects the icons of multiculturalism. According to Lesch, the successive Muslim Arab nationalists in Sudan maintain that majority religion, Islam and Arabic should be the interconnected model defining the country's national identity and in practice, they have introduced it into legal laws. In reaction, Muslims of the Northern Sudan such as the Fur in Darfur, the Beja, the Nuba and the Christians and Animists of the South reject this model. Lesch concludes that the population of the South tends to maintain its Christianity and Animism and its indigenous languages beside English, while the majority people from Darfur, Nuba Mountains and Beja want to maintain their linguistic identity and special characteristics of their Islamic ritual sacrifices. $^{103}$

With respect to the ethnic and religious diversity in Sudan, this research rejects the constitutionalised system of Arabisation and Islamisation and alternatively, it considers religion as a basic equal right for individual citizens, both the majority and minority. This equal right needs protection from the leadership in power of national institutions in Sudan as a government.

Individual Animists, Christians and Muslims need a constitution that offers free spaces for worship within sovereign Sudan. Tuula Sakaranaho notes that the European landscape has been abruptly transformed to multi-religious centralism, where there are new non-Christian minorities. This phenomenon creates a dilemma for the European Union (EU) leaders between the need to protect their sovereign borders from the emerging new cultures, and at the same time to show hospitality to the new residing immigrants with their new religions and cultures. Sakaranaho concludes that the 'Charter of Fundamental Rights' that adopts the principles of democracy and human rights in dealing with its societies helps the EU leaders face this dilemma, because, it urges with respect to diverse cultures, religions and traditions of the territorial residents within the EU sovereignties. ${ }^{104}$ Granting equal freedom to different religious minorities and the majority in public social structures of a state creates the religious interaction of these groups as free territorial residents. Conversion from one religion to another religion is not necessary to be institutionalised specifically in a national constitution. Instead, it should be constituted by permitting individual men and women of different faiths to interact in public spaces of recreation, such as clubs, markets, schools, parks, city squares, bars, gardens and zoos. These social recreation centres are the facilitating instruments of free religious conversion. According to An'Naim, sometimes, religious conversion occurs

\footnotetext{
${ }^{103}$ Lesch, op. cit., p., 21.

${ }^{104}$ Sakaranaho, Tuula (2006). Religious Freedom, Multiculturalism, Islam, Cross Reading Finland and Ireland, Muslim Minorities Volume 6, Leiden: Martinus Nijhoff Publishers and VSP, p. 3.
} 
without being intended, because of human interactions in commercial, social, and cultural atmospheres. $^{105}$

This researcher argues that when power in a state commences to legally institutionalise religious conversion, then that institutionalisation contains an underlying ideological discourse of proselytism. It is an institutionalised religious propaganda that may not necessarily promote religious dialogue, discussion, cooperation, pluralism, and tolerance. Instead, its adherents embed the means of its implementation in political and economic institutions. According to Martin, proselytisation has been characterised as a negative term, which may embody coercive means disguised in established economic, political, social and diplomatic institutions. Martin concludes that the negativity of this term stimulates some Christians to reform their theological missions that propagate witness, dialogue, and cooperation aiming to build religious tolerance in the world of cultural pluralism. ${ }^{106}$

The institutionalisation of the means of the religious proselytisation into public institutions of a state implies the building of racial institutions in a state. Racism is an abstract universal idea without colour or smell. It only becomes visible, when it is applied in national institutions. According to Omi and Winant, racial dynamics in a racial state are manifested in education, religion, law, economics and science. ${ }^{107}$ The author has observed the genesis of public institutions in Sudan that manifest extreme connotations of racism, which is embedded in national institution against the population of the Black Africans. For example, in the capital city of Sudan, Khartoum a police force can be instructed to move to some specified residence, where the inhabitants are mostly Black African Muslims from the Nuba Mountains, Ingessana Hills, Darfur and the Christians and Animists from the South and evict them. Currently, the inhabitants that reside in ghettos around Khartoum were mostly evicted from their original locations of Hechish between Jabra and Suq alShabbi and Dar al- Salam at Wed- Amaar. The present government, under President Al-Bashir escalates the eviction of the specific groups. It authorises police organs to evict the defined identities frequently and isolate them at desolate locations. There the victims of the eviction begin

105 An'Naim, Ahmed Abdullahi. “Competing Claims to Religious Freedom and Communal Self-Determination in Africa, in Abdullahi Ahmed An'Naim (ed.) (1993). Proselytization and Communal Self-Determination in Africa, New York: Maryknoll, p. 2-3.

${ }^{106}$ Martin, Paul and Winner, Harry. "Religious Proselytization Historical and Theological Perspectives at the End of the Twentieth Century”, in Abdullahi Ahmed An’Naim (ed.) (1993). Proselytization and Communal Self-Determination in Africa, New York: Maryknoll, pp. 29-30.

${ }^{107}$ Omi, Michael and Winant, Howard (eds.) (1994). Racial Formation in the United States from the 1960s to the 1990s ( $2^{\text {nd }}$ ed.), London: Routledge, p. 10. 
to create names for their desert areas such as Bentiu, Dar al-Salam, Ras Shathan and Angola and many others around the suburb of Khartoum. Simone observes that, the increasing numbers of the African cultural characteristics from the Christian and Animist South into the institutions of Northern Sudan provokes the Islamic power in Khartoum. And alternatively, it resorts to the legislation of provisional laws, which allow the authorities in Provincial Khartoum to bulldoze the residential houses of these Black Africans and pack them into vehicles and drive them farther into the sandy desert around Khartoum. ${ }^{108}$ For functionalist sociologists, a racial regime that discriminates its institutions fixes discrimination in those institutions to deny the target group from equal privileges and services. Wodak and Reisigl explain that race is a social construction, which a discriminating power in a state applies to legitimate its ideological tool of oppression and exploitation of specific social groups and deny them access to material, cultural and material resources, such as work, welfare services, housing and political rights. ${ }^{109}$ In practice, institutions of state which are built on racial discrimination remain in conflict. The affected group reacts and introduces measures of resistance. These measures can be a serious demand for participation in power, autonomous or self-rule government or self determination that may lead to complete a distinct new territorial sovereignty. According to Miles, a state that uses racial categories in dealing with citizens causes a reaction from the affected community. The reactionists use the racial concept to construct alternative as a basis for political resistance and fight for more political autonomy, wider participation and independence. ${ }^{110}$

The consistent habitual practice of power that evicts or relocates specific ethnic groups, because of their origin, colour, ethnic and culture manifests a paradigm of racial discrimination to the territorial citizens. This practice builds an endless cycle of racial conflicts and violence in the national institutions of Sudan. It motivates the African Christians and Animists of the South to regret being abruptly annexed to the Islamic Arab North as one territorial people and experience systematic discrimination and racism. Malwal argues that Arab Muslims control power and use intertwined religion and race to great effect. They seek to establish dominance over the heterogeneous religious and racial groups in the country. The Turco-Egyptian regime united these diverse groups through "historical accident" and it was through another unexpected historical

\footnotetext{
${ }^{108}$ Simone, op. cit., pp. 28-31.

${ }^{109}$ Wodak, Ruth and Reisigl, Martin (2001). Discourse and Discrimination Rhetoric's of Racism and Discrimination, London: Routledge, pp. 57-58.

${ }^{110}$ Miles, Robert (1993). Racism after Race Relations, London: Routledge, p. 28.
} 
accident that Great Britain handed the political power to this minority Muslim Arab population upon independence. Malwal concludes that the adoption of Arab race and Islamic religion in national institutions as a model for unifying its essential diversity revives the remorseful historical mistreatment by the Muslim Arabs to the Christian and Animists of the South. ${ }^{111}$

The perspective of discrimination prompts this author to present a question: what is the alternative resolution that can end perpetual racial domestic conflict in Sudan? The authentic source to provide a clear response to this question comes from the Sudanese decision makers. Two prominent and influential political figures on the national affairs in Sudan offer parallel ideological responses in writing and speech. First, Abel Alier former President of the Southern Sudan Region from 1973 until early $1982^{112}$ argues that the domestic racial conflict will constantly remain unchanged, unless a legislative power enacts a national constitution based on secular democratic pluralism to be applied to all levels of national institutions. ${ }^{113}$ Second, Nafi Ali Nafi, the current Presidential Assistant of Sudan argues in a political speech that the building of Sudan as an Islamic state, where its constitutional laws are derived from Sharia is an imperative objective of any Muslim in the country. It is a Will of God and must be dictated with all available means, including stripping power by force as long as that power imposes Sharia with Arabic in orienting the national institutions in Sudan. $^{114}$

These two conflicting syntheses from the prominent leaders of Sudan give us a comprehensive perspective to construct specific names for these competing ideological proponents. First, we call the group of the political forces in Sudan that urge the legislature to take Sharia as the sole source of national laws and Arabic as an official language of national institutions adherents of ethnic territorial nationalism. Second, the opponent group to this model of constitutional approach consists of the adherents of ethnic territorial national pluralism. The advocates of the latter ideology press for the adoption of pluralistic and secular constitutional system that sustains different religions,

\footnotetext{
${ }^{111}$ Malwal, Bona Madut. "Racism, Cultural and Religious Bigotry” in Martin Doornbos et al. (eds.) (1992). Beyond Conflicts in the Horn: The Prospect for Peace, Recovery \& Development in Ethiopia, Somalia, Eritrea \& Sudan, The Hague: Institute of Social Sciences, p. 7.

${ }^{112}$ Denoon, Donald. "The Education of Southern Sudanese Refugees" in Dunstan M. Wai (ed.) (1973). The Southern Sudan the Problem of National Integration, London: Frank Cass, p. 161. Wai defines Abel Alier as a Southern Sudanese with integrity and respect who was appointed as Vice President of Sudan in 1971.

${ }^{113}$ Alier, Abel. "Solution to the Constant Conflict in Sudan?" in Martin Doornbos, et al. (eds.) (1992). Beyond Conflict in the Horn. The Prospect for Peace, Recovery, \&Development in Ethiopia, Somalia, Eritrea, \& Sudan, The Hague: Institute for Social Sciences, p. 13.

${ }^{114}$ Sudani (2008, July). "Nafi Ali Nafi Idaat Ocampo len Tathel Intikabat, Nafi Ali Nafi the Warrant Arrest of Ocampo Does not Obstruct Elections”, Arabic Newspaper, Sudani, Issue No. 958, p. 1.
} 
cultures, customs and languages of the diverse citizenry within the territorial Sudan. Two are for our analysis. First, secularisation of institutions in Sudan refers to privatisation of religion as an entity of individual person and the state for the whole citizens. Wilson defines secularisation as "the process by which religious institutions, actions, and consciousness lose their social significance" by privatising as a subject of individuals set apart from a national constitution. ${ }^{115}$ Second, there is a reason for adopting the term 'ethnic' to both conflicting proponents in search of a national identity. In essence, there is no unified definition to the term ethnic. In Greek, Ethnikos is an adjective and ethnos is a noun and both were used for the identification of foreign people in the Greek territory. ${ }^{116}$ In the Medieval era, the term was used as a derivative word from Latin, ethnicus to mean heathen referring to a Gentile, a non-Jewish person. ${ }^{117}$ Moreover, the contemporary anthropological studies show that the term is used to define people of one culture, custom, religion or language. ${ }^{118}$ This perspective substantiates that the term 'ethnic' fits to both contradictory ideological categories of constructing national identity in Sudan, since the latter definition can mean a common culture. Therefore, the two schools of thought present opposing and distinctive ideologies, where each group has its common culture that unifies its people as one ethnic group. Specifically, it is under this context, where the term ethnic is adopted here and at the same time, the term territory represents each group, since each of them is identified within the territorial Sudan, but with parallel ideological perceptions.

Generally, there is no consensus on what constitutes national identity in a nation- state. Modern theoretical models which have been used in making national identities in the world have not represented uniform approaches. Some consider the political culture of democratic pluralism as a basis for building national institutions in opposition to the autocratic, theocratic, aristocratic or the military regimes. According to Schraeder, in 2000, one hundred and six Heads of States and Premiers from the democratic governments assembled in Warsaw, Poland to discuss the promotion of global democracy. The meeting led to the 'Warsaw Declaration' which urges the global institutions to introduce extensive transition to the multiparty democratic pluralism in order to

\footnotetext{
${ }^{115}$ Wilson, Bryan (1991). Secularization and Rationalization, Oxford: Oxford University Press, p. 26.

${ }^{116}$ Phadnis, Urmila (1989). Ethnicity and Nation- Building in South Asia, New Delhi: Sage Publications, p. 13.

117 Ibid.

118 Yinger, J Milton (1994). Ethnicity Source of Strength? Source of Conflict? New York: State University of New York Press, p.10. Hastings, Adrian (2004). The Construction of Nationhood, Ethnicity, Religion, and Nationalism, Cambridge. Cambridge University Press. p. 3.
} 
uproot all forms of authoritarian systems. 119 Some claim that national constitutions of democracies represent equal rights of cultural and religious diversities of majority and minority groups. Yet, sometimes the majority promotes its cultural identity in national media. ${ }^{120}$

The argument for the representation of both the majority and minority groups in a democratic constitution causes a serious political dispute among students of the targeted universities for this research in Sudan. Instances of this dispute come from the question in the questionnaires of the study which states: "How do you want national identity of these regions to be defined in a national constitution of Sudan and why do you think so?" Their responses to this question are divisive as one of Muslim Arab student asserts that "... the best constitutional system that suits Sudan is the Islamic-Arab democratic pluralism for the reason that it unifies the cultures of our people ... in order to make us look like one nation in cultural identity". ${ }^{121}$ In contrast, the Dinka Christian Animist student states: "For me, I want a secular democratic constitution, because it allows multiculturalism to flourish in our social structures". ${ }^{122}$

The conflicting opinions of the two students represent the essential conflict of national identity in Sudan. The adherents of ethnic territorial nationalism interlace democracy with the religious ideology of Islamic-Arab culture as a means of deposing diversity and inserting the majority cultural identity based on Islam and Arabic culture. On the other hand, the adherents of ethnic territorial national pluralism resist the majority intent to eradicate diversity and seek the adoption of a secular constitution. In this way, parallel models build up and become the centre of political departure in national institutions of the country. El-Affendi argues that there has been no democratic multiparty regime in Sudan that succeeded to constitute a national constitution for inclusive citizens. Since 1958, the first 'Constitution Commission' that involved all different democratic multi-parties could not reach a consensus in adopting the Islamic nor secular constitution. The Muslims majority urged the adoption of an Islamic constitution and the Christians and Animists minority demanded the adoption of irreligious laws derived from diverse secular sources, until the military government, under Ibrahim Abboud from the Beja ethnic group of the Red Sea seized power in the same year. ${ }^{123}$

\footnotetext{
${ }^{119}$ Schraeder, Peter J "Promoting International Community of Democracies" in Peter J Schraeder (ed.) (2002). Exporting Democracy Rhetoric vs. Reality, London: Lynne Rienner Publishers, p. 1.

${ }^{120}$ Steinberg, Stephen (1989). The Ethnic Myth, Race, Ethnicity, and Class in America, Boston: Beacon Press, p. 13.

${ }^{121}$ Ali Khalid at University of Khartoum, Al-Gezira region.

${ }^{122}$ Madut Majok at University of Juba.

${ }^{123}$ El-Affendi (1990), op. cit., p. 373.
} 
This phenomenon of constitutional conflict continues in Sudan to our present day. Currently, the Interim Constitution of Sudan Article (5) paragraph (1) states: "Nationally enacted legislation having effect only in respect of the Northern States of the Sudan shall have its sources of legislation Islamic Sharia". Second, paragraph (2), under the same article states "Nationally enacted legislation applicable to Southern Sudan shall have as its sources of legislation ... the values and the customs of the people, including their traditions and religious beliefs". ${ }^{124}$ In this regard, two ideologies of ethnic territorial national pluralism and ethnic territorial nationalism develop in parallel among students.

\subsection{Ethnic territorial nationalism}

The model of ethnic territorial nationalism that transforms Sudan's national identity into an ArabIslamic state came into effect when the former Military President Nimeiri imposed Sharia on 8 September 1983. ${ }^{125}$ Carolyn Fluehr-Lobban describes Sharia as a form of law that dismantles the principle of equal status to all citizens in Sudan. Under it, the Sudanese non-Muslims become second-class citizens. ${ }^{126}$

The issue of Sharia divides the students; some Muslims reject it and some support it. For example, the question is religion important and what is your concept about the world in accordance to your religion, does it allow space for other religions(s), if so, please explain? El-Nur Mohammad, a Muslim Arab student states: "Islamic religion is important, because, it embodies Sharia, which provides justice to all citizens". ${ }^{127}$ However, H A, a Muslim Arab student states: "Religion is sometimes good, but Sharia is not needed. When Nimeiri imposed it, the majority of Muslims and non-Muslims in Sudan were astonished and formed the political alliance for the restoration of the democratic multiparty system that would rescind it; unfortunately, the Umma party cheated the masses". ${ }^{128}$ According to Kok, after the imposition of Sharia as the law for Sudan, the democratic political parties of Umma and Sudanese professionals formed a political alliance, the 'National Alliance for National Salvation' (NANS), and signed a charter in London 1985. And even though the SPLM was a guerrilla political opposition at war with Nimeiri, it also signed the charter in a

\footnotetext{
${ }^{124}$ Interim Constitution of the Republic of the Sudan Entered into Force July 2005.

${ }^{125}$ Woodward, Peter “A 'New Sudan'?” in Herve Bleuchot et al. (eds.) (1991). Sudan, History, Identity, Ideology, Oxford: Ithaca Press, p. 207.

${ }^{126}$ Fluehr- Lobban, Carolyn (1987). Islamic Law and Society in the Sudan, London: Frank Cass, p. 280.

${ }^{127}$ El-Ghazali Mohammad, University of Khartoum, el-Gezira Region.

${ }^{128}$ H. A. University of Khartoum, Ja'aleen ethnic group.
} 
document called 'Koka Dam Declaration' in Ethiopia in March 1986. The charter invoked the abrogation of Sharia and the NANS organised popular uprising and deposed President Nimeiri on 6 April 1985. After that the 'Military Transitional Council, TMC', under Major General Abdul

Rahaman Suwar Al-Dhab formed a transitional government. In April 1986, a democratic multiparty system based on pluralism was restored and Sadiq Al-Mahdi became Premier and rejected the nullification of Sharia. ${ }^{129}$

Later under pressure from the political parties of DUP, the Sudanese Communist Party (SCP) and the Union of the Sudan African Parties (USAP), Al-Mahdi acquiesced for the suspension of Sharia constitutionally, but the radical Islamists of the NIF, seized power militarily. On 29 June 1989, Brigadier Omer Hassan Ahmed Al-Bashir declared himself as the President of Sudan and 'Islamic fundamentalism' in its extreme form returned to power. Al-Bashir called his military regime as Thura Al-Ingaz Al-Watoni (National Salvation Revolution) with the intent to impose Islamic identity and control religious diversity. ${ }^{130}$ Montague observes that, whenever racism fails in its endeavours to prove that the source of group differences lies in the biological field, it falls back upon justification in terms of divine purposes. ${ }^{131}$

Two scholars allege the 'Salvation' of religious and racial discrimination in national institutions of Sudan. First, according to An'Naim, the NIF of the 'Salvation' defines Sharia constitutionally as a divine law and such definition prohibits all possible attempts of the Sudanese citizens to criticise or discuss it, so that they offer alternative legal views which fit them. The NIF alleges that the critics of this law are apostates and such accusation is a crime punishable by death, under section (126) of Sudan's Penal Code of $1991 .{ }^{132}$ Second, Collins argues that the NIF, which has changed its name to the NCP, pursues the creation of a 'New Sudanese' identity that is defined as Islamic and Arabic to the exclusion of other religions and languages. For the NCP, to be a Sudanese requires the adoption of the twin pillars, Arabic and Islam as an interconnected model of homogenising the people of Sudan. The ideology is too rigid and it rejects any negotiation and compromise over these

\footnotetext{
${ }^{129}$ Burr, J Millard and Collins, Robert O (1995). Requiem for the Sudan War, Drought, Disaster Relief on the Nile, San Francisco: Westview Press, p. 74.

${ }^{130}$ Lesch op. cit., p. 159. In 1989, Umma, DUP, USAP and SCP unanimously agreed to the pressure of the SPLM to the "freezing" of Sharia in 'National Constituent Assembly', but the minority political party, the, NIF led by Hassan Abdullah Turabi coordinated with some of its senior officers, led By Omer Al-Bashir in the national army and overthrew the democratic regime and imposed Islamic fundamentalism pp. 55, 113.

${ }^{131}$ Montagu, Ashley (1972). Statement on Race, London: Oxford University Press, p.53.

132 An'Naim, Abdullahi Ahmed (Summer 2003). Re-affirming Secularism for Islamic Societies, New Perspective Quarterly Vol. 7, pp. 1-2.
} 
twin models. Those who could not conform to this creed would be excluded for not being Sudanese. In order to produce the 'New Sudanese', the 'Islamic fundamentalists' introduce a complete ideology to indoctrinate, shape and control the population of Sudan from all aspects of life, where everything is Islamised and Arabised. Sharia is applied to its extreme by codifying strict Islamic traditions and employing them to justify Jihad against the defined citizens as "apostates and heathens" in the country. ${ }^{133}$

The NCP is a synonymous with the NIF and 'Salvation' in Sudan. Its political orientation analogically, manifests three interrelated ideological characteristics of 'Islamic fundamentalism' in facing its political dissidents. First, it pursues the model of violence in defence of its Islamic ideology. And in order to apply that model, it seeks sources of funds and an army, and since sometimes, war is fought for some economic advantages to the combatants ${ }^{134}$, the 'Salvation' entices the impoverished population in dire need of basic services to its Islamic military recruitment. Thus, some young Muslim men quickly aggregate and register with the Islamic militia, Popular Defence Force (PDF), often to gain personal advantage. According to the Sudanese Human Rights Organisation (SHRO), the NIF recruited Arab Muslims, under the PDF, which is an oriented militia to promote its ideology of defending Islam from those it has labeled as pagans and apostates. Each member of the PDF receives a lump sum of 50,000 Sudanese pounds, a gun and a horse in order to join the Jihadists. SHRO concludes that the government promised the recruits to any booty taken from a group suspected to be loyal to the opposition forces. ${ }^{135}$

Furthermore, Petterson says that foreign Muslim activists like Osama Bin Laden contributed funds for the application of Jihad. Under Jihad, the NCP accused the Dinka ethnic group at their villages of being allies with the SPLM, which resists the transformation of Sudan into an IslamicArab state. ${ }^{136}$ Second, the NCP adopts the systematic killing of its opponents in the name of Jihad, where it divides its dissidents into 'apostates' and 'pagans'. According to Rone, the Government of Sudan under the NIF applies two penalties of Sharia against its opposition forces. First, the collective and second the individual penalties, the former applies to recalcitrant group or apostates.

\footnotetext{
${ }^{133}$ Collins, Robert O (1999, September). "Africans, Arabs, and Islamists: From the Conference Tables to the Battlefields in the Sudan”, African Review, the African Studies Association, Vol. 42, No. 2, pp. $106-107$.

${ }^{134}$ Harris, Marvin (1987). Cultural Anthropology, New York: Harper and Row Publishers, p. 194. Harris argues that in wars, the interest of the fighters involved is an egoistic tendency to get booty.

${ }^{135}$ Sudan Human Rights Organisation (2000). "SHRO-.Cairo Report on Slavery in the Sudan”, The Sudanese Human Rights Quarterly, Issue No. 9, p.3.

${ }^{136}$ Petterson, Donald (2003). Inside Sudan Political Islam, Conflict and Catastrophe Revised and Updated, Oxford: Westview, p. 115.
} 
In this way, the apostates are those Sudanese Muslims in the SPLM and could be brought back, under the sway of an imam that promulgates Jihad against them. The latter applies to those prescribed as unbelievers, enemies of God and His Messenger, refers to the non-Muslims in the SPLA. Rone concludes that Jihad is a method, which the NIF uses to confront such groups citing from the Holy Quran 2:193, 8:39: "For whoever has heard the call of the Messenger of God, peace be upon him, and has not responded to it, must be fought, until there is no persecution and the religion is God's entirely". ${ }^{137}$

Jihad in Sudan is a synonym for 'ethnic cleansing'. Preece defines 'ethnic cleansing' as an ideology that intends to eradicate ethnic diversity, so that a certain political territory reflecting one ethnic and religious identity is produced. ${ }^{138}$ In a visible sense, Jihad in Sudan is ethnic cleansing to both non-Muslims and Muslims who reject the ideological system of 'Islamic fundamentalism' in institutions of Sudan. Scholars and some human rights agencies provide practices of the NCP Jihadists. First, according to de Waal, under Jihad, the political oppositions that cooperated with the SPLM were characterised as apostates in Sudan. For this, the Holy Book of Quran and the mosques in the areas of the oppositions were devastated. For instance, eleven mosques of the Nuba Muslims were incinerated and the mosque of Mukla village of Ingessana Hill was bulldozed. de Waal concludes that the Holy books of Quran and the mosques in the villages of Gedamayeb and Rabbasim of Beja Muslims to the east of Sudan were also destroyed. ${ }^{139}$ Second, Jok observes that, when the PDF launched attacks against the villages of the non-Muslim ethnic group, the Dinka in Northern Bahr el-Ghazal and Abyei in South Sudan, they killed the adult men, captured children, women and took them to the Islamic territory of the North. ${ }^{140}$ Third, Iyob and Khadiagala argue that the system of the Islamic fundamentalism in Sudan that emerged in 1989 has been utilising and manipulating all Islamic religious tenets "to justify the killings of Muslims by Muslims as is exemplified by the campaigns of ethnic cleansing in the Nuba Mountains ... and of Darfur" and the Christian South. ${ }^{141}$ Forth, SHRO reports that the NCP Jihadists on some occasion assaults exempted women and children from the killing during its Jihad. Such exemption is an

\footnotetext{
${ }^{137}$ Rone, Jemera, (1996). Behind the Red Line Political Repression in Sudan, New York: Human Rights Watch, pp. 5-7.

${ }^{138}$ Preece, Jeniffer Jackson. (1998). "Ethnic Cleansing as an Instrument of Nation-State Creation Changing State Practices and Evolving Legal Norms, Human Rights Quarterly, Vol. 20, No. 4, p. 822.

139 de Waal Alex (ed.) (2004). Islamism and Its Enemies in the Horn of Africa, Addis Ababa: Shama Books, p. 73.

${ }^{140}$ Jok, Madut Jok (2001). War and Slavery in Sudan, Philadelphia: University of Pennsylvania Press, p. 112.

${ }^{141}$ Iyob, Ruth and Khadiagala, Gilbert M (2007). Sudan the Elusive Quest for Peace, London: Lynne Rienner Publishers, p. 32.
} 
implementation of the Islamic ideological plan of transforming the non-Muslim children and women of the Dinka as legal properties to the believers, the Muslims in the 'land of peace'. SHRO concludes that the NCP government defines its territory as the 'land of peace' and the opposite is the land of 'war' in reference to its interpretation of the Islamic precept. ${ }^{142}$

Different human rights agencies started to report this kind of government treatment of the children and women of the Dinka to the United Nations (UN) and in turn, the UN held a session to deliberate over this issue and finally decided to send a panel of UN experts headed by Gaspar Biro to Sudan. This delegation was mandated to investigate the circumstances of these allegations. In his report, Gasper warned the UN that there was an alarming increase in cases of slavery, servitude, slave trade, forced labour in the jurisdiction of Sudan against some specific groups. ${ }^{143}$

The empirical development of the ideological 'Islamic fundamentalism' in politics in the past and present in Sudan shows that religion, Islam is a very important factor; however, Muslim politicians quickly exploit it for their own political egos. Its exploitation displays a scenario of a competition over the racial ideologies which each leader uses to justify the need for a change from the present religious status quo to the other farther defined ideological and ethnic religious category. At this stage, the competition may develop in a long or a short term to religious or ethnic sectarian violence within one religious faith. This religious phenomenon gives us a space of an argument that a constructed national identity, under the basis of religious doctrines produces an artificial ethnic, religious and political uniformity, but is still susceptible to more political and religious schisms, because the ethnic inclination can become stronger than the religious one. We have two examples in the Islamic Sudan, where Islam shows precarious development of this type. First, Warburg says that in January 1885, Muhammad Ahmed Bin Abdullah, known as Al-Mahdi captured power in Khartoum from the joined British and Egyptian colonialism and declared Sudan as an Islamic state. After his death, the 'Islamic Council' paid allegiance to Khaliffa Abdullahi Bin Muhammad from al-Ta'asha tribe of the Baqqara Arab as a successor. Later, the Ashraf Arab tribe led by Muhammad Sharif Bin Hamed considered the al-Ta'asha tribe to be an inferior group to represent the Islamic state and conspired against the successor. In reaction, within twelve months in power, the successor, Abdullahi Bin Muhammad with the support of his kinsmen from Darfur, especially the Governor of

\footnotetext{
${ }^{142}$ Sudan Human Rights Organisation (2000). "SHRO-.Cairo Report on Slavery in the Sudan”, The Sudanese Human Rights Quarterly, Issue No. 9, p.3

${ }^{143}$ UN Special Rapporteur (1995). "Gaspar Biro Introducing His Report to the UN", Commission on Human Rights April 16. 1996. ECOSOC, E/CN.4/1996/62, para. 97 (a), p. 52.
} 
Darfur, Muhammad Khalid attacked and defeated the Ashraf. In the aftermath the Muslim Arab Governors from the Ashraf were removed from all administrative powers with the exception of Usman Diqna that represented the non-Arab ethnic group, the Beja. ${ }^{144}$ Second, de Waal explains that the NIF that aims to build an Islamic state in Sudan started in 1999 to wrangle over power and interpretation of Islam, until it rifted into two political organisations the NCP, under President AlBashir and the PCP, under Turabi. After that split, members of the former NIF from Darfur who allied with Turabi were considered unfaithful ones and replaced in the essential security apparatus with those loyal to Al-Bashir. General Abdalla Safi el-Nur from Reizegat Arab tribe of the Southern Darfur, an ally to Al-Bashir was chosen and brought into the security apparatus. El-Nur intensified the recruitment of the Arab ethnic groups in Darfur to fight against the indigenous Muslims of Fur, Massaliet and Zagahwa making Darfur a disaster zone of violence between the militia Muslim Arabs, janjaweed and the indigenous Muslim Africans of Darfur. ${ }^{145}$

The present state of the racial war between the janjaweed and the indigenous ethnic groups of Darfur marks the climax of racism within the model of ethnic territorial nationalism in Sudan. Such a racial approach gives an impression that power in Sudan rejects cultural ethics of responsibility over its inclusive diverse ethnic groups. In the modern world, different ethnic and religious groups need a pluralistic system in all public scripts in state as equal citizens in institutions. According to Marshal, political citizenship means the right of a citizen to be treated fairly, irrespective of ethnic, religion, gender, conscience or colour. ${ }^{146}$

The unstable phenomenon of political development in Sudan forces the author to argue that a successful democracy in Sudan needs to de-link itself from religious ideologies with regard to its citizens. It needs to adopt the territorial democratic pluralism, where religions are mere references in the national constitution and not derivative sources of legislation for the diverse citizenry.

\subsection{Ethnic territorial national pluralism}

Sociologically, the ethnic model of pluralism is a political construct that emerged after the fierce resistance of ethnic minorities in USA to the sociological ideology of the 'melting pot' that aimed to assimilate them into the culture of ethnic majority. In general, it is an ideological theory that

\footnotetext{
${ }^{144}$ Warburg, Gabriel (2003). Islam, Sectarianism and Politics in Sudan since the Mahdi, Madison: The University of Wisconsin Press, pp. 40-4.

${ }^{145}$ de Waal, Alex, (2005). Briefing: Darfur, Sudan: Prospects of Peace, African Affairs, the Journal of the Royal African Society, Vol. 104, No. 114, pp. 127-8.

${ }^{146}$ Marshal, Thomas Humphrey (1973). Class, Citizen, and Social Development, London: Greenwood Press, pp. 12-3.
} 
explains the scientific approach to the interaction of different peoples with different cultural traits in a territory with intent to assimilate the minorities into the dominant culture. Some sociologists in the USA conducted a research in 1910; under the theme what happens when a group of people of divergent cultural groups come into contact and the possibility of conflicts arises. The answer to this research theme was unsettling; one sociologist, Robert Ezra Park provided the answer to the thematic question of the study. Park postulated a race relations cycle that comprises three cycles, 'contact', 'accommodation' and 'assimilation' of the minority culture. ${ }^{147}$ Some argue that Park never meant to imply a complete disappearance of ethnic differences. Instead, the intention was tolerance to the culture of the unique ethnic groups; however, its opponents view ethnicity as a powerful phenomenon in public institutions in the USA and urge its maintenance within different institutions. Under these conflicting theoretical positions, the model of ethnic pluralism emerged as one of models in construing a national identity. ${ }^{148}$

This study argues that the prevailing civil violence in Sudan is a product of the new consciousness within the Islamic North emerging from the peripheral regions in resistance to the 'melting pot' and in favour of ethnic territorial pluralism. In practice, this claim is derived from the new reconstruction of ethnic political parties that are based on Muslim Arab parties versus indigenous Muslim African parties in western Sudan of the Nuba Mountains, Darfur and the eastern Sudan of the Beja ethnic group. According to Morton, in Western institution, Sudan is defined as a state divided into an Arab Muslim North and an African Christian Animist South. Currently, this definition is misleading, since within the North there are ethnic political organisations which claim representation of their ethnic minorities in opposition to the main Sufi order parties of the Umma, DUP and the NIF. These new regional movements from the marginal areas, include, the 'Sudanese National Party' (SNP), a Nuba party and the 'Beja Congress' composed exclusively of the Beja, an ethnic group with a strong sense of maintaining its linguistic and cultural uniqueness along the Red Sea and Kassala provinces. ${ }^{149}$

In addition, members of the indigenous ethnic groups from Darfur resigned from the Northern Islamic parties and formed their own ethnic based political organisations mainly the Sudan's Liberation Movement (SLM) and the Justice and Equality Movement (JEM). Mans explains that

\footnotetext{
${ }^{147}$ Park, Robert Ezra (1950). Race and Culture, Glencoe III, p. 124.

148 Steinberg, op. cit., p. 47.

${ }^{149}$ Morton, John (20002). "Ethnicity and Politics in Red Sea Province, Sudan", African Affairs, the Journal of the Royal African Society, Vol. 88, No. 350, p. 65.
} 
most of these organisations armed indigenous of Darfur were members of the Northern political parties of Umma and NCP and now they have deserted those Islamic political organisations and opted for armed confrontation against the centre. The parties claim that they want to eradicate the political suppression, oppression and marginalisation of their region, Darfur in terms of power and wealth sharing. Mans concludes that SLM asserts that Sharia must be removed and replaced by a secular system which rejects racial exclusion. ${ }^{150}$

${ }^{150}$ Mans, Ulrich (2004 April). "Briefing: Sudan: The New War in Darfur", African Affairs, the Journal of the Royal African Society, Vol. 103, No. 411, pp. 291-400. 


\section{ORIGIN OF RACIAL EXCLUSION AND INCLUSION IN SUDAN}

Essentially, the current conflicts in Sudan originated from early power in the state that constructed divisive racial settings of the territorial population into 'Blacks' and 'Browns', 'Muslims and Christian Animists', 'Slaves and Frees', Africans and Arabs, 'Animists and pagans, ${ }^{151}$ and "Northerner and Southerner". ${ }^{152}$ These racial categories are void of political comprehensive meaning among the territorial citizens; instead, they simply represent racial exclusion and inclusion. According to Guba and Lincoln, exclusion is a coherent body of performance that power pursues in setting imbalances of national institutions, which can be "understood in reference to objectives and purposes attached" to its setting. ${ }^{153}$

The body of the first political setting of public institutions in Sudan was based on the social exclusion and inclusion of 'us' and 'them, 'we' and 'they' 'theirs' and 'ours'. ${ }^{154}$ The first phase of this setting commenced in 1821, when Muhammed Ali Pasha, Viceroy of Egypt ordered his army to invade the 'Nilotic Sudan' in order to access Black slaves for the slave trade and to fill the ranks of his army. His 'Turco-Egyptian Rule' modernised local administrative systems, under Hakimdar (General Governor) in its four provinces of Dunqulah, Berber, Sinnar and Kordofan all in the Northern Sudan. The regime established a system of education, a monetary system, post and telegraph services and laws in courts to the exclusion of the South, Nuba Mountains, Ingessana Hills and Darfur. Those marginal regions remained as mere sources of slaves. ${ }^{155}$ Under the new Turco-Egyptian administration, the Jellaba, a term that refers to the Northern Sudanese Muslim Arab merchants and administrators crossed into the deep territories of the South and extracted

\footnotetext{
${ }^{151}$ Iyob and Khadiagala, op. cit., p. 19.

152 Simone, op. cit., p. 25.

${ }^{153}$ Guba Egon G Lincoln, Yuonna S “Competing Paradigms in Qualitative Research" in Norman K Denzin and Yuonna S Lincoln (eds.) (2003). The Landscape of Qualitative Research Theories and Issues, London: Sage Publications, pp. 197-198.

${ }^{154}$ Bauman, Zygmunt (1990). Thinking Sociologically, Oxford: Basil Blackwell Ltd, p. 40. Bauman argues that among all the distinctions and divisions that break the continuity of co-existence is the division of 'us' and 'them, 'we and 'they'.

${ }^{155}$ Hassan, Gubara Said, op. cit., pp. 7-9.
} 
slaves, especially from the 'Nilotic country' of the Dinka, Nuer, Anyuak, Jur Col and Shilluk. ${ }^{156}$ Second, the exclusive category was passed to the second power in the same form and manner. ${ }^{157}$ In 1881, a Muslim Arab, Muhammad Ahmed Bin Sayyid Abdullah Al- Mahdi instigated the Muslim people of the North and the Animists of the South to rebel against the Turco-Egyptian regime. Under his influence, the Dinka from the South participated in uprooting the Turco-Egyptian forces in their territories and Al- Mahdi took complete control of power in $1885 .^{158}$

The administrative system of Al-Mahdi soon revived a breaking in the social and political continuity between the Animists of the South and the Muslims of the North. It shifted from the solidarity of having fought collectively in dismantling the foreign administration to the former category of dividing the territory into distinctive divisions of Muslim Arabs in the North versus the African Animists in the South. The former were superiors and slavers and the latter were inferiors and slaves. ${ }^{159}$ Furthermore, his successor Khaliffa Abdullah maintained these constructed categories of excluding the Southern identities from the system. From1885-1889, the regime allowed slavers to move to the South and access slaves for the revival of the dwindling supply of domestic labour in the Northern Sudan. ${ }^{160}$

In the view of Miles and Thränhardt, when a territorial region is built on the logic of exclusion with its underlying shaping practices, then racist conceptions of 'otherness' become operational within the national institutions. ${ }^{161}$ The extensive experiences of racial exclusion, since the origin of Sudan to some ethnic groups has built consistent racial category of 'otherness' based on the

${ }^{156}$ Kebbede, Girma (ed.) (1999). Sudan’s Predicament Civil War, Displacement and Ecological Degradation, Hampshire: Ashgate Publishing Limited, p. 11. The Turco-Egyptian regime promoted the existing trafficking in black population of Nilotic South. The Jellaba kidnapped thousands of slaves from the South.

${ }^{157}$ Nuba Muslim students such as Ibrahim Muhammad el Nur, from Omdurman Alia University, Zinab Abdel Hussien from Omdurman Ahlia University and Sara Babker and Zaki Kouku from University of Juba maintain that social exclusiveness of the Nuba Mountains, Darfur and South Sudan was inherited by the Arab rule of Mahdi from the Turco-Egyptian rule.

${ }^{158}$ Nikkel, op. cit., p. 58. During the revolt of el Mahdi against the Turco-Egyptian regime, the Governor of the regime, Frank Miller Lupton of Bahr el Ghazal reported that he heard the "Dinka shouting the war cry of the Mahdists", while fighting the Turco-Egyptian forces and carrying the green flag of the Ansar soldiers. And Agar Dinka attacked the regime military garrison at Rumbek.

${ }^{159}$ Collins, Robert O (1962). The Southern Sudan, 1883-1898 a Struggle for Control, London: Yale University Press, p. 23. Al-Mahdi regime re-established the social exclusion of the indigenous population of the South. The regime permitted its loyal Muslim Arab militants, Ansar to continue with the policy that legitimated Muslims Arabs from the North to enslave non-Muslims from the South.

${ }^{160}$ Johnson, Douglas Hamilton (2003). The Root Causes of Sudan's Civil Wars, Oxford: James Currey, p. 6. The regime of Khaliffa permitted the Jellaba to move to the South and bring slaves to rescue the shaking economy of the regime.

${ }^{161}$ Miles, Robert and Thränhardt, Dietrich (eds.) (1995). Migration and European Integration the Dynamics of Inclusion and Exclusion, London: Pinter Publishers Ltd, p. 3. 
opposing categories of Muslim Arabs in the North of Sudan and the indigenous Christians and Animists in the South. These constructed racial categories have made it impossible to achieve unified political resolutions between the opposing identities in order to build unified institutions for the people of Sudan. Any political, social or economic project on the agenda within the institutions of the state encounters parallel interpretations based on these categories. This is reflected in the question posed to students in the questionnaire of this research, which states "How did the east, west, far north and centre become the Northern Sudan Region in exclusion of the South and what does the name of your region and Sudan mean in your native language and do you experience any difficulty in articulating it ?" The students' responses to this question provide paradigms of conflicting categories depending on the region from which they came. Most Muslim Arabs of the North argue that the division of Sudan was a foreign construct: British imperialism divided Sudan into the South and the North. ${ }^{162}$ 'There is no difference between the South and the North; the South was just a compass and not people'. 'Our brothers from the South listen to the Christians from the Western World. Those Whites people do not want our political and economic stability. They always say that Muslim Arabs are bad; they enslave non-Muslims'. ${ }^{163}$ A Muslim student concludes that Islam is a good religion; it fights slavery and maintains good relationships in the social order. ${ }^{164}$

In contrast, some Christian and Animist students from the South reject this assertion. As it appears from the answers of the questionnaire question that asks "Do you think national projects such as oil, Jonglei Canal and Al-Gezira Scheme can create cross interaction and equal work opportunities for the diverse regions of Sudan, if yes or not, please explain?" Some of them claim that 'Arab Muslims continue ... to create conditions for enslaving the people of the South. They create conditions that kill and starve us, until our present day'. ${ }^{165}$ 'Lucky enough, the presence of our environmental natural swamps impede them from identifying all those means and possibilities. Yet, these means are frequently applied against our population of the South in the twenty-first century' ${ }^{166}$ and when 'the people of America and Europe ... say that we want to know the reason for killing us, then the Arabs respond that the Western World is responsible for this problem. The White people have become the loophole of escaping crimes committed against the Animists and

\footnotetext{
${ }^{162}$ Mustafa Ali Muhammed, a Muslim Arab from the Shaiqqiyyia at the University of Khartoum.

${ }^{163}$ Afaf Abdel Raziq from Ja'aleen at the University of Khartoum.

${ }^{164}$ El- Sharif al Hadi Muhammad, a Shukuriya Arab, University of Khartoum.

${ }^{165}$ Ring Akol Anei a Dinka Christian Animist, University of Juba.

${ }^{166}$ John Riny, a Dinka Christian and Animist, University of Bahr el-Ghazal "The Muslims in power instituted indirectly a means of killing people, which is a serious crime in the twenty-first century of human rights".
} 
Christians. Did the West ... delegate the successive Muslim Arab Governments in Khartoum to kill the people of the South or they themselves choose to do so? For us in the South, we do not ... admire ... political liars'. 167

In Sudan serious political disagreement between the Christians and Animists of the South in opposition to Muslim Arabs of the North is not rationally discussed as a spontaneous internal problem without encompassing the Western World. It is a common political pattern of political and intellectual 'Islamists' in Sudan to accuse the West as the cause of various political crises in the country. For instance, Mohammad argues that the Southern Sudan became a closed district in the thirties, free from any Islamic influencing contact. In mission schools, the Southern students were oriented that their 'brothers' from the North were the source of their present life of hardship. In the religious and history classes, missionaries exploited every opportunity to keep the memory of slavery alive. ${ }^{168}$

The pattern of accusing the West is widely reflected in the responses of Muslim Arab students. For example, the questionnaire question that states: "How did the east, west, far north and centre become the Northern Sudan Region in exclusion of the South and what does the name of your region and Sudan mean in your native language and do you experience any difficulty in articulating it ?" Some students who have answered this question argue that the concept of the South to be a state is a creation of the USA and the European Union (EU). ${ }^{169}$ For example, one said; the West uses the Christians and the Animists from the South as its Trojan horses to execute its detrimental project against the unity of this country and Islam. ${ }^{170}$ One student concludes that the behaviour of the Western World towards the South has caused a departure in political opinions and led to the current 'hatred' of the indigenous people of the South, Nuba Mountains and Darfur to the Northern Arab Muslims. ${ }^{171}$

Participant observation shows that it is not easy to find political consensus between Muslim Arab students in the North and Christian Animist students from the South. Most of them provide parallel conflicting views in reference to the given questionnaires. Further typical examples in which this conflict is revealed come from the question: "Do you think national projects such as oil; Canal Jonglei and Al-Gezira Scheme can create cross interaction and equal work opportunities for the

\footnotetext{
167 Anyuon Akol Mou, a Dinka Christian Animist, University of Bahr el- Ghazal.

${ }^{168}$ Mohammad, Hassan Makki (1989). Sudan: The Christian Design, London: Islamic Foundation, p. 76.

${ }^{169}$ Saeed Mustafa, a Muslim Arab from Shaiqqiyyia at the University of Khartoum.

${ }^{170}$ Lila Salah Misery from the Reizegat Arab of Western Sudan at the University of Khartoum.

${ }^{171}$ Hassan Salah Jaeli from Kababish Arab of Northern Kordofan at the University of Khartoum.
} 
diverse regions of Sudan, if yes or not, please explain?" Answers to this question unfold the value of swamps of the Nile. Many Christians' and Animists' students from the South describe the swamps of the Nile tributaries as "... have been our sanctuaries from the aggressive forces that come from the North of Sudan". ${ }^{172}$ Some of them define these swamps as their "... natural and valuable friendly creatures which have been protecting us from Muslims Arabs of the Northern Sudan' and now the Islamic power wants to remove them by digging a canal in Jonglei. We shall never accept this claimed national project". ${ }^{173}$

A new phenomenon that the researcher observes from some 'Christian-Animist students is the personification of swamps, hence, they receive special eulogy such as “... we praise swamps for their care and protection of us from our public enemies. We the Nilotics have been the victims of Muslim Arabs, since the time of Al-Mahdi State, where we were their slaves". ${ }^{174}$ Some claim that, during the last war between the SPLA and the Government of Sudan $(\mathrm{GoS}){ }^{175}$, the swamps were hiding locations one explains: "During the war, the government forces could not carry heavy machine guns to the swampy locations, where people used to hide ... swamps have saved many lives among the Nuer, Dinka, Shilluk, and Anyuak people of the Nile". ${ }^{176}$. Some conclude that the intention of the government to dig a canal in South Sudan to drain the swamps so that its water can be used for irrigation of farm lands sounds partially reasonable, but there might be also a hidden agenda to remove these sanctuaries'. ${ }^{177}$

The value of the swamps and the digging of a canal is an intertwined issue among Christian and Animist students. As one of them states "Swamps are our fences that protect us constantly from our foes, the Muslim Arabs". ${ }^{178}$ The other claims that the digging of a canal opens possibilities of shifting from the intended category of economic interest to an unspecified interest in the future. ${ }^{179}$

\footnotetext{
${ }^{172}$ Adeng Kon, a Dinka at the University of Juba: "Swamps are the medicines that prevent the aggressive forces of Arab Muslims that send their army to kill us".

${ }^{173}$ Gum Majok at the University of Bahr el- Ghazal. "In my opinion, digging of a canal in Jonglei is a removal of "natural and valuable friendly creatures. The swamps are our shelters from the ambitious Muslims o the North".

${ }^{174}$ Chol Liem, a Nuer at the University of Juba.

175 Prunier, Gerard (2007). Darfur the Ambiguous Genocide, London: Hurst \& Company, p. 59.

${ }^{176}$ University of Juba students, Adiang Akol, Benjamin Mel Leek, Anthony Marial, Lueth Thuc, Cirino Gai.

${ }^{177}$ Kiir Atem Bol at the University of Juba, Ajak Marial at Omdurman Ahlia University, Samuel Chol, University of Juba, Dut Lul at the University of Upper Nile, Michael Kot at the University of Juba.

${ }^{178}$ Dhor Amet, a Christian Dinka Animist, Omdurman Ahlia University argues, "if we allow the Government in Khartoum to dig the canal, then swamps will ebb and our Arab enemies can attack us on open ground".

${ }^{179}$ Geng Lueth, a Dinka-Christian Animist, University of Juba.
} 
However, a Muslim Arab student describes the digging of a canal to drain swamps as a significant national project for the development of agriculture in Sudan'. ${ }^{180}$

According to Deng, before or after the advent of Islam, Arabs from the North of Sudan accessed slaves from South Sudan with difficulties. Natural swamps, flies, climate humidity and violent resistance from the Nilotic people, Dinka, Nuer, Shilluk and Anyuak made it impossible for Arab slave traders to penetrate deeply to the Southern territory. ${ }^{181}$

These perceived conflict interpretations to the swamps are paradoxical, but our concern is that the claims of students show the point of racial departure in political views and interpretations of events and plans between the Christians and Animists in one category and the Muslim Arabs of the North in the opposite. Such constant political binaries function negatively in designing economic, cultural and social projects for the territorial people of Sudan.

\subsection{Project of Canal Jonglei and interpretations of its objectives}

In 1978 Sudanese and Egyptians Governments initiated a joint project to dig a canal in the Jonglei region in South Sudan. The former President of Sudan Nimeiri gave a green light for its excavation. It was planned that the digging would be finished in the middle of 1980, but the SPLM defined the project as one of its main military targets and that definition halted the work with a little less than a third of the project left unfinished. ${ }^{182}$

The justification for the project was that the sudds (the swamps) of the White Nile impede the swift flow of water towards the north. The stated intention was that a canal would drain the swamps and allow the flow of water to the north and that water would be used for the irrigation of a larger swath of land for agricultural food production that might benefit two countries, Sudan and Egypt. ${ }^{183}$ The Northern Muslim Arab students who responded to the question; Do you think national projects such as oil; Canal Jonglei and Al-Gezira Scheme can create cross interaction and equal opportunities for the diverse regions of Sudan ... describe the digging as a great project for the development of the country. ${ }^{184}$, but one Christian and Animist student describes the digging as: “....

\footnotetext{
${ }^{180}$ Mohamed Diem, a Muslim-Shaiqqiyyia Arab, University of Khartoum.

${ }^{181}$ Deng, Francis Mading (1995). War of Visions Conflict of Identities in the Sudan, Washington D C: Brookings Institution, p. 69.

${ }^{182}$ Kebbede, op. cit., pp. 18-19.

${ }^{183}$ Suliman, Mohammed Suliman (199 March 13). "A Major Causes of Armed Conflict in the Sudan. The Case of the Nuba Mountains", a paper presented at the International Conference on: Community Based Natural Resources Management, Washington D C, United States Institute for Democracy, p.5.

${ }^{184}$ Taj Hassen Thurar, Muhammad Salim, Yhaya Abdel Nabi, Malik Hussein, University of Khartoum.
} 
an abhorrent project that threatens the underlying concepts of the swamps". ${ }^{185}$ The students present different suspicions against the realisation of this project, including its impacts on the economy and security of the South.

\subsubsection{Economic benefits and insecurity}

First, some students claim that the digging of a canal in Jonglei drains the swamps and makes them vulnerable to the Muslim Arab governments of Egypt and Sudan. ${ }^{186}$ The students point out that the swamps prevent the transfer of heavy machine weapons which the two governments may use against them, if there is an abrupt war. A Dinka student elaborates this suspicion as an experience and states: "On different occasions, government tanks could not reach our areas of swamps, during the war between the SPLA and Muslim Arab Jihadists in the Northern Sudan, since May 1983 to January 2005". ${ }^{187}$ Some Nilotic students claim that swamps protect them from the people whom they describe as "ambitious Muslim Arab slavers". ${ }^{188}$ Brink writes about the racial relationships between the Dutch and the Khoin people of South Africa, where the former misrepresents the latter and in reaction against this racial misrepresentation the latter argue as:

We of the Khoin, we never thought of these mountains and plants, these long grasslands and marshes as a wild place to be tamed. It was the White men who called it wild and saw it filled with wild animals and wild people. To us, it has been always friendly and tame. It has given us food, drink and shelter, even in the worst of drought. It was only when the Whites moved in and started digging and breaking and shooting and driving off the animals that it really became wild. ${ }^{189}$

For the majority of Christian and Animist students of the South, the swamps have never been weird. They have been their sources of fish and unadulterated water, bulwarks for security and above all, areas for grazing their cattle and other animals. It is only the plans of two governments, Egypt and Sudan that would indeed, transform them to unnatural wilderness. These arguments of students go as, first, a Shilluk articulates "The plan of Egypt and the Northern dominated government to dig a canal in Jonglei to drain swamps is an ill plan. It denies us from fish, clean water, and evaporation of swamps water for rain in our lands and it pains me ... much whenever I

\footnotetext{
${ }^{185}$ Mayom Kur, a Dinka Christian Animist, University of Bahr el-Ghazal.

${ }^{186}$ Ameir Deng Malong, Marwan Mayen, Mamier Luac, David Changoth, Ngor Madit, University of Bahr el Ghazal. Kuany Ayuel, Riek Liem, Amet Dau, and Ayang Dok, University of Juba.

187 Thiik Riny, Dinka Christian Animist, University of Juba

${ }^{188}$ William Diing "How can you mix the slaver Arabs with those whom they have enslaved for centuries? Swamps are here to stay to keep out the Muslim slavers who are always Arabs".

${ }^{189}$ Brink, Andre (1983). A Chain of Voices, London: Fontana, p. 21.
} 
hear it; but all in all, any attempt to undermine the validities of these swamps represents an invitation for the resumption of war in Sudan" ${ }^{190}$. For Nuer student, the benefits of these swamps include security as he explains "During the war between the SPLA with the Muslim fundamentalist government in Khartoum, the government fired cattle and herdsmen in grazing lands with their aero planes from the sky. Fortunately, those beside ... natural swamps, were saved. But, if you were somewhere at the dry locations, then you are gone. Today, if the digging of the canal is revived, then I would look for a gun and fight. ${ }^{191}$

Some Southern Sudanese students are much concerned over the economic advantages of this project and the role of those advantages to their security. For them, if the canal is dug, then the Jellaba, would introduce mechanised agricultural farms in the drained land and in turn, the wealth produced from these agricultural farms might be used against the local people. Perhaps, it would be used for buying weapons with which to attack them, while the swamps would not be there to shield them. $^{192}$

These conflicting interpretations towards the economic benefits from the Canal Jonglei plan represent the racial division of Sudan. Sociologically, the racial character of racism is explained on the basis of economic structural plans and its continuity. Hall observes that social division which assumes a distinctively racial or ethnic character can be explained principally by reference to economic structures and processes introduced in accessing such economic benefits. ${ }^{193}$

The native students from the South' resistance to the digging of the Jonglei' Canal is not only limited on racism of cultural xenophobia; it also includes their fear of the negative effect of the digging on the Southern environment.

\subsubsection{Cultural xenophobia and ecology}

In 2003, the national media in Egypt started to advertise that the Governments of Sudan and Egypt had revived the programme of settling some Egyptian farmers into South Sudan in order to cultivate there. Some Egyptian diplomats discussed it in public media confirming the request of Sudan from the Government of Egypt to send five thousand Egyptian farmers to be permanently settled in the

\footnotetext{
${ }^{190}$ Yor Kur, a Shilluk-Christian Animist, University of Juba.

${ }^{191}$ Nuer Christian Animist, Omdurman Ahlia University.

192 Deng Majok, a Dinka-Christian Animist, University of Khartoum argues: "The purpose of digging a Canal is to apply scientific tracks for farming, but we shall not benefit from the produced crops. The digging opens the way for the Muslim Arabs to come and live among us with their unwanted Islamic culture".

${ }^{193}$ Hall, Stuart, "Race, Articulation, and Societies Structure in Dominance", in Stuart Hall (1980). Sociological Theories: Race and Colonialism, Paris: UNESCO, p. 306.
} 
South. ${ }^{194}$ For some students from the South that initiative of resettlement is connected to the digging of a canal in Jonglei, so that a space for their resettlement and cultivation would be secured. In their view, that plan is very dangerous for the future of their unique culture. It makes them fear possible cultural clashes between them and the settled Arab Muslims within their territory as one of them argues: 'If a canal is dug, then the Jellaba and Egyptian agriculturalists would move to occupy our lands as farmers and pollute our culture and that may lead to violence of cultural differences'. 195 Another more harsh comment comes from a student who claims that: 'the digging opens the way for Arab slavers to smuggle their slavery culture to our places. ${ }^{, 196}$

Mohamed Suliman explains such conflicting interpretations between the people of the North and the people of the South of Sudan towards this project of the canal in Jonglei region. According to him, the Nilotic peoples (Dinka, Nuer, Shilluk, Anyuak, Bari Mundari and Jur Col) fear the prospect of a flow of aliens that may settle in their midst and be a source of possible conflicts. Back in November 1974, rumours that Egyptian farmers would be sent to the canal area immediately sparked students' riots in Juba, capital city of the South. ${ }^{197}$

An analysis of these student riots in resistance to the project of the canal in Jonglei reveals two situations. First, it denotes the racial phenomenon, where each group of the racialised social categories is influenced by the media and comes to the conclusion that promotes racism, under the pretext of protecting cultural identity and avoidance of insecurity. The rejection of the Egyptian farmers and the Jellaba by the rioting students gives an impression of classified racial groups, where each one is defined as a 'foreigner' and not needed among 'us' (the people of the South). It represents the dynamic building of racial territories of 'they' (Muslim Arabs of Egypt and the North of Sudan) and 'we' (Christians and Animists of the South). According to Huysmans, reading newspapers, magazines, watching television and listening to the radio give an impression of racism

\footnotetext{
194 Beginning of the Practical Integration (2003, January 12) "Badaya al-Takamol al Faeli ma Al-Sudan, Al-Gensia alSudania lel Messereen shreth Asasi lel Hosul ala Geta Aradth fil Monaba al-Nil The Beginning of the Practical Integration with Sudan, Sudanese Nationality for the Egyptians Is the Real Condition for the Acquisition of a Peace of Land on the Nile Valley", Arabic Newspaper, Al-Messa, Issue No. 1243, p.2. Former Egyptian Ambassador to Israel, Muhammad Basuni reported that Sudan requested Egypt before to send it five thousand Egyptian farmers to rehabilitate South Sudan and own the lands for agriculture.

${ }^{195}$ Silvia Martin Dut, a Dinka-Christian Animist, University of Khartoum.

${ }_{196}$ Awak Ateny, a Dinka-Christian Animist, University of Bahr el-Ghazal.

${ }^{197}$ Suliman, op.cit., p.5.
} 
and xenophobia of insecurity in social structures. The security tale constructs the racial identity of 'us' and 'they' threaten not only individuals, but the whole "us of our identity". 198

Second, ecological or environmental claim of the Christian-Animist students from the South is a very essential point which needs serious attention and genuine study. First, one would argue that there are adequate and serious deficiencies in the adopted research data on digging a canal in Jonglei. Two governments of Sudan and Egypt favour the aims and objectives of the research data that concentrate only on the digging of such a canal for the achievement of the flow of water to the lower zone of the region at the north ${ }^{199}$ without reviewing the parameters of the various ecological impacts and the effects of the drained swamps of the White Nile to the Nilotic community and the environment. Digging requires a reliable research body that will adequately consider the fauna and flora of the region. And any limited data assessment would automatically reflect negative impacts on the ecology and that would explain an adequate political opportunism of racial exclusion of the Christians and the Animists of the Southern region to benefit from their fauna and flora of their environment. The presence of fauna and flora is important for the states of Sudan and Egypt to provide alternative measures in protecting the very genus and exotic species of birds, animals and plants in the environment to avoid the possibility of their extinction. Practically, the swampy area of the 'Nilotic country' embraces different species of animals, plants and birds. All these living beings rely on these swamps for their survival. ${ }^{200}$ Elsiddig observes that the Government of Sudan fails several times to respect natural environment, which different animals use as their refuge place ${ }^{201}$

\subsection{Racism in social structures}

It is common to find two racial categories among Muslim students of the five targeted universities for this research. The African Muslim students are often in opposition to the Arab Muslim students. The research question: have you ever experienced any form of discrimination in any region of Sudan, if so please explain reveals that the present relationships among Muslim students are based

\footnotetext{
${ }^{198}$ Huysmans, Jef "Migrants as a Security Problem: Dangers on Securitizing' Societal Issues" in Robert Miles and Dietrich Thränhardt (eds.) (1995). Migration and European Integration the Dynamics of Inclusion and Exclusion, London: Pinter Publishers Ltd, p. 53.

${ }^{199}$ Suliman, Mohamed Suliman op.cit., p.5.

${ }^{200}$ Wilson, H H (1902, October). "A Trip Up to Khor Felus, and Country on the Left Bank of Sobat, The Geographical Journal, Vol. 20, No. 4, pp. 401-405. There are hartebeests, elephants, Graff, hippopotamuses, rhinos, buffalos, deer, antelopes, crocodiles, bustards, francolin, Guinea fowl, geese, ducks, fishes and teals.

${ }^{201}$ Elsiddig, Elnour Abdalla (2007) Jebal Marra Potentials for Resources and Rural Development in Darfur, Khartoum: University of Khartoum: Khartoum University Press. p. 2.
} 
on race, rather than, religion. Some instances can be found from the answers of the African Muslim students to the questionnaires. First, a Muslim student from the Fur ethnic group of Darfur claims that 'social structures in the Northern Sudan justify every day a sense of racism against the Fur. the student states: 'Any African Muslim boy from Darfur working in periphery restaurants of Muslim Arabs in Khartoum is called Fur, even though the boy might not be from Fur and the reason for calling him so, is (sic) to pay him less than a Muslim Arab boy working with him in the same restaurant'. 202

Second, some argue that: '... if you read Islam, you would (sic) find it a good religion coming from God; when you come to meet with Muslim Arabs in political and social institutions of Sudan, then it looks unattractive'. ${ }^{203}$ This unattractiveness comes into religion, because the 'the successive Muslim Arab governments in Sudan reject the Islamic norm that urge equality of all Muslims and favour the Arab race in public institutions'. ${ }^{204}$

In contrast, some Arab students' reject these claims at their answers to the question "Is religion important and what is your concept about the world in accordance to your religion, does it allow space for other religion(s)?" They argue that: "Islam is not a worthless religion; it is a worthy religion that devotes the life of a believer to Allah (God), but some Muslim leaders mingle it with ... corrupted politics. Such negative practice distorts its holy message among the Dinka, the Nuer, the Shilluk and the Bari and all (sic) people in the South, including the Nuba in Nuba Mountains". ${ }^{205}$ Another respondent wrote: "After the foundation of the infidel organisation (sic), the so-called SPLA and SPLM, the people of the Nuba Mountains and Darfur (sic) joined it gradually. The reason for their ... participation in the rebellion ... against us was that the successive government forces discriminated, marginalised, and killed them unjustly in their regions. The correct message of Islam is peace and justice. When a Muslim person kills and enslaves a person without a reason, then that was not the ethos of the religion our Prophet Muhammad preached for all people in order to become Muslims". ${ }^{206}$ One student concludes that "... practice of killing is a deviation from Islam and it is difficult to bring the Animists people of the South back to the fold of Islam. Today, many brothers from the South, even at our university here hate whatever (sic) involving a Muslim Arab and prefer to discuss anything involving an African Muslim of the Nuba Mountains, Darfur, Beja

\footnotetext{
${ }^{202}$ Adam Muhammad, Omdurman Ahlia University.

${ }^{203}$ Al-Amin Zubeir Kuku, a Nuba Muslim, the University of Khartoum.

${ }^{204}$ Al-Nur Fatah Rahman, a Nuba Muslim, the University of Juba.

${ }^{205}$ Ahmed Mohamed, an Arab Muslim, Ja'alei, Omdurman Ahlia University.

${ }^{206}$ Mirghani el-Haj, an Arab Muslim, al-Gezira region, Omdurman Ahlia University.
} 
and Ingessana Hills. This is racism against us and we need to rethink, otherwise, African Muslims of these areas will join their lost brothers in Christianity."207

Some scholars argue that Islam in Sudan is not free from racial discrimination between Muslim Arabs and Black Muslim Africans. A Black Muslim could still be a slave of an Arab Muslim. First, Fisher points out that, during the time of the slave trade, Black Muslim clerics dared not travel freely. They feared being kidnapped and sold in slave markets. This phenomenon forced Ali Dinar, a former Muslim ruler of Darfur to react against the Kababish Arab Muslims of the Northern Kordofan. Ali asked them to provide the legitimacy of enslaving other free Muslims. ${ }^{208}$ Additionally, according to Idris, the Muslim Arabs of the Northern Sudan are not satisfied that a Black African converted to Islam in the country is of the same equal status of faith in Islam. A Black Muslim could be enslaved in social institutions and mocked as hayawan al-natigq (a talking animal). ${ }^{209}$

The author argues that this phenomenon of racism among students, Muslims, Christians and Animists alike at the higher institutions of learning has a link with social and political orientation in national institutions of the country. It is a reflection of the social and political environment that is full of a racial norm that promotes it, instead of a norm that rejects it. And subsequently, it builds up conflicting racial institutions based on the categories of the African Muslims that unite with the Christians and the Animists against the Arabised Muslims in North Sudan. The cultural norm is a regulating power in social and political relationships. It displays a function in the organised system of social, political and cultural structures of people. The norm directs behaviours of social groups within a territory to promote what is wanted and reject what is unwanted. It regulates and directs rules and guidelines for the behaviour of society by distinguishing between the vicious and the virtuous in social institutions and commending nations, people and social groups in a specific environment to divide human practices into wrong and right. Norms emerge from human evaluation of its economic, cultural and social practices, where the socially embraced norms are promoted and unwanted are controlled. ${ }^{210}$

\footnotetext{
207 Amani Jaa'fer, an Arab Muslim, Kawahla

${ }^{208}$ Fisher, Humphrey J (2001). Slavery in the History of Muslim Black Africa, London: Hurst and Company, p. 72.

${ }^{209}$ Idris, Amir Hassen, op. cit., pp. 16-17, 37, 40.

${ }^{210}$ Hirschman, Jane R and Munter, Carol H (1988). Overcoming Overeating Living Free in a World of Food, Massachusetts: Addison Wesley Publishing Company Inc, p. 9. After the emancipation of racism in the USA the majority of Americans started to react negatively to those deviating generally from the new expected norm that dismantles racism as an undesirable and culturally sanctioned phobia.
} 
Sudanese Muslim Africans, Christian Africans, Animist Africans and Muslim Arabs might not be serious in teaching norms to their children in social and cultural institutions of learning to avoid the binary racial categories of a Muslim Arab versus a Muslim African or a Muslim versus a Christian or an Animist'. Implementation of norms, however, depends on individuals or groups in social structures. It is the responsibility of each member in social institutions to react against those deviating from the common norms that maintain positive relationships. Teaching children to grow in social and political surroundings with norms which are entirely void of all forms of racism and discrimination can be an alternative resolution to racism and discrimination. Such an orientation is a necessity for the institutions of Sudan to function smoothly and coherently without racial segregation. Sudan is a state party to the African Charter on Human and Peoples' Rights (ACHPR). Article two of this Charter articulates that every individual shall be entitled to the enjoyment of the rights and freedoms recognised and guaranteed in the present Charter without distinction of any kind of race, ethnic group, colour, sex, language, religion. ${ }^{211}$

At the moment, some of the UN organs have introduced measures for combating all such negative norms which support racial discrimination. For instance, on 4 December 2008, the United Nations High Commission for Refugees (UNHCR) financed a coalition of interested parties for a global campaign against discrimination of women by "encouraging fathers and father figures to set example to young males". 212

The modern political Muslim elites in North Sudan set symbolic examples which promote discrimination in national structures. Alier argues that Muslims in power, since the foundation of Sudan to the present day build institutions that revive the aggressive shape of slavery. After the independence of Sudan on 1 January 1956, power started to give names to the public roads in Khartoum, capital city of Sudan. Today we have a road in the centre of Khartoum that bears the name of Zubeir Pasha, while Zubeir was responsible for the institution of slavery, slave trade and all forms of capture and mistreatment to all the slaves from South Sudan. Alier concludes that the increasing eulogy of slavers in the national institutions of Sudan makes it difficult to ease the memory of slavery from the descendants of the victims of slave trade and that represents a symbolic action of promoting atrocious practices of slave trade in the county. ${ }^{213}$

\footnotetext{
${ }^{211}$ African Charter on Human and Peoples' Rights, adopted June 27, 1981, OAU DOC. CAB/LEG/67/3rev 5, 21.I.L.M. 58(1982), entered into force Oct. 21, 1986.

$212 \mathrm{http} / / \mathrm{www}$.unhc.org/news/493805812.html.

213 Alier, Abel (1990). Southern Sudan: Too Many Agreements Dishonored, Reading: Ithaca Press, p. 45.
} 
Zubeir Road at the centre of the national capital city of all the citizens of Sudan represents a deviation example not only from the respect to the former victims' relatives of the slave trade and slavery, but also from the international convention of slavery of $1926 .{ }^{214}$ Without the introduction of alternative norms which reject the deviation from the accepted public values among the people of Sudan, then the racial category of the 'lost brothers' will gradually persist in national structures of the territorial Sudan.

\subsubsection{Stereotype of the 'lost brothers'}

Interaction between different groups in social structures opens a way for the construction of the phenomenon called stereotype. It is a social perception invented by members of a certain social group as an in-group. The opposite is an out-group. The members of an in-group generally apply this constructed perception to the out-group without exception as their inclusive characteristics rather than individual ones. ${ }^{215}$

Sudan social institutions are not free from this social categorisation. It has its stereotype of the 'lost brothers'. For example, responses to the question: "What do you think about the people in Sudan who follow other religious faith and traditional rituals than yours and please state the reason(s) of why you think so?" reflected stereotypes such the following: 'Our existing political and religious conflicts among us ... came to be, because of British colonial policy towards the South of Sudan. Colonialism closed some areas to Arab Muslims of the North to interact with the pagans of the South. Free interactions between us, Arab Muslims and the pagans of the South would have helped in converting the pagans from Animism to Islam, instead of being lost to Christianity. ${ }^{216}$ 'Islam is the best religion; I believe that without interference of Kawajat (White people) (sic) with their religion, Christianity, our things would have had a chance to move positively'. 217 'Imagine Islam, a religion that establishes just social order is rejected in the South. I believe our brothers from the South have missed the way to heaven. ${ }^{218}$ 'We would have been one and all of us together would have been living as good peaceful Muslims receiving the blessing of God, but our brothers got astray to the foreign religion and the Kawajat ... with their Christianity planted the seed of

\footnotetext{
${ }^{214}$ Slavery Convention Signed at Geneva on 25 September 1926.

${ }^{215}$ Esler, Philip (1971). Conflict and Identity in Romans the Social Setting of Paul's Letter, Minneapolis: Augsburg Fortress, p. 21.

${ }^{216}$ Saeed Jazuoli at the University of Khartoum from Arab of Ja'aleen.

${ }^{217}$ Fatima Abdu at the University of Khartoum.

${ }^{218}$ Nugud Abdel Masaud at the University of Khartoum.
} 
hatred in the minds of the Southerners to dislike the religion of their brothers in the North. ${ }^{219}$ One of them presents a conclusion that: 'I believe those who follow other religions in the South are lost ... from the way to heaven. Islam is a very special and clear religion in its message to mankind. Those who reject its salvaging revelation, like our brothers in the South and Nuba Mountains are not alone lost, but bitterly dead with their idols. ${ }^{220}$ At the same time Christian-Animist students from the South reject this stereotype of the 'lost brothers' in their responses to the same question. In their view, 'all religions are important in all aspects, but the activities of Arab Muslims in Sudan project Islam as a bad religion. For this, we reject it and embrace Christianity, but they call us ... 'lost brothers'. ${ }^{221}$ Another student states: 'Calling us 'lost brothers' is a naïve construction, the question that our brothers fail to answer is; have we ever ... been at one time Muslims, in order to call us lost'? There are genuine questions here. First, the Nubians were Christians and had quickly developed oblivion to Christianity. Why did they accept the religion which had annihilated their culture? Why on earth did they deny their civilisation? They are lost brothers indeed and we have preserved the civilisation of the Old Christian culture in Sudan. The Christian heritage has been here for centuries ... and centuries, but, it is unfair for the Nubian people in Sudan to avoid the resumption of their Christian religion, tradition and civilisation to their children. Were they not Christians? ${ }^{222}$

The history of Sudan teaches that Christianity, under the Nubians pre-dominated the North of Sudan for almost one thousand years. It became the official religion in the region in the sixth century and lasted more or less, until the fourteenth century. During their wars against the Muslims, the Christian Nubian Kingdoms resisted the change of their Christian identity for seven hundred years. ${ }^{223}$ The Nubian Muslim students from Mahas, a subsection of the Nubians ${ }^{224}$ argue: 'a lost person is one assimilated (sic) to another racial identity. The Nubians maintain their identity. So, we are not lost, since we are not assimilated to Arab culture. It might be true that some Nubians are lost, but not the whole Nubian ethnic divisions. ${ }^{225}$ 'Some of us are not ready to trace their (sic) genealogical lines to the Arabs. It is true, we are Muslims, but Islam is a religion ... it is a religion

\footnotetext{
${ }^{219}$ Sara Omer Nasser el-Din, University Khartoum.

${ }^{220}$ Malik Abdellah Yassein, a Muslim from Kababish Arab of the Northern Kordofan at the University of Khartoum.

${ }^{221}$ Gabriel Riek at the University of Juba.

${ }^{222}$ Biar Tong Anei, a Dinka at the University of Bahr el Ghazal.

${ }^{223}$ Clarke, Peter (ed.) (1990). The World's Religion Islam, London: Routledge, p. 165

${ }^{224}$ Idris, Amir Hassen, op.cit. p. 6.

${ }^{225}$ Ali Nimeiri Sadiq, Omdurman Ahlia University.
} 
of God to all mankind, irrespective of race, ethnic, and the colour. The membership of becoming a Muslim is not acquired through a recitation of an Arab name. It is not; it is very clear in Holy Quran. For me, I am a Mahas and a Muslim. I speak Mahas as a Nubian language. I really speak it and ... it is my identity and I am proud of it, so I am not lost'. ${ }^{226}$

The ethnic Nubian Muslim students from the Mahas have illustrated an essential political issue for analysis. What really constitutes identity in the context of Sudan language, religion or tradition? In the view of some Christian-Animist students, self identity is derived from a combination of customs, traditions, language and religion. This definition is derived from their following arguments. 'It is not enough for one to be a Christian, and Animist or a Muslim. A person must ... maintain ethnic culture in dealing with situations. Me, I am not lost because, I am a Christian Animist and a Jieng. I speak my language, but my identity is not alone based on the language of the Jieng; it is not enough to speak a language. Some people do not know their languages, yet they follow their traditions and customs. Our brothers, the Nubians have abolished their traditions and customs of Christian civilisation and are lost to the Islamic Arab culture'.227

Some continue to claim that 'the Nubians are 'lost brothers' certainly and we always tell our colleagues at the university to retrieve their heritage and teach it to their children., 228 'It is unfair for this great nation ... to avoid restoration of their religion, Christianity, tradition and civilisation to their children. For me, if I do not warm my memory with my traditions, then I am not a Jieng; the Nubians are lost Christians. They deny their identity and claim the religion of Arabs and the culture of Arabs in their way of social life'. ${ }^{22}$ According to Idris, the Nubians, both the Mahas and the Danagella, at the far north of the country have retained their language as a sense of their identity despite their adoption of Arab culture in their institutions. ${ }^{230}$

Historically, the stereotype of 'lost brothers' is a generalised racial category to the heterogeneous ethnic groups residing in the South of Sudan as Christians and Animists. Their nationalism emerges in opposition to the new construction based on the ideology of Islamic and Arab traditions. The groups orient themselves towards the people of East Africa in order to build an African nation. On the other hand, the political Islamic sector in North Sudan builds its nationalism on the resistance to the African traditions and favours linking up with Arab world, especially Egypt to build an Islamic

\footnotetext{
${ }^{226}$ Suwad Muhammad, Omdurman Ahlia University.

${ }^{227}$ Lual Deng Guer, University of Upper Nile.

${ }^{228}$ Kong Tim Lual, University of Upper Nile.

${ }^{229}$ Charles Akol Ngong, University of Bahr el- Ghazal.

${ }^{230}$ Idris, op. cit., p. 6.
} 
Arab cultural identity in Sudan. El-Affendi explains that the nationalism of the people of South Sudan as a political ideology that rejects Muslim and Arab North Sudan and attaches itself to the African countries of Kenya and Uganda. And the nationalism of the Muslims in the North is constructed on the Arab-oriented culture. The educated classes of Arab Muslims seek to attach the identity of the state to Egypt and the Arab world. The Northern intelligentsia aim to regain back the "lost brothers" from the South who follow the alien values of Christianity and reject their "brothers" in the North who are longing to restore them back to the fold of the Islamic fashion. ${ }^{231}$

\subsubsection{Logic of stereotypes}

Yinger observes that the logic of stereotypes comes up in an interacting society, which intends to maintain some kinds of social discrimination. For instance, most European settlers to the 'New World' developed a comfortable rationalisation, in which the native Indian was "a lying, thieving, murdering savage". ${ }^{232}$ Today, laying such attributes on the indigenous population of Indians is not longer regarded as socially acceptable. Yinger concludes that, such a descriptive generalisation came from a well-established system of culture that many people who have had an opportunity to witness an Indian would come to accept that all the Indians are of such characters and that form of culture is an ethnic stereotype. ${ }^{233}$

In the case of Sudan, it is not easy to reach a conclusion over the stereotype of the 'lost brothers', but the British imperialists manipulated religious and ethnic sentiments of the territorial population of Sudan in a way that suited their political logic. According to Lesch, British colonial power followed the prejudices of the preceding regimes of the Turkyyia and the Mahdiyya. Those regimes conceived the people of the South as pagans. After the British power conquered Sudan and dismantled those regimes, it began to legalise the flow of Christian missionaries to the South to convert the local Animists to Christianity. And at the same time, it refused those Christian missionaries permission to propagate their religious propaganda to the Islamic North. ${ }^{234}$

Today, Muslim Sudanese leaders in power apply the same logic. The government encourages the method that intertwines the ethnic race of Arab with the Islamic religion as inter-independent entities. Mere conversion to Islam as a religion is not enough. A confessed Muslim needs to identify

\footnotetext{
${ }^{231}$ El-Affendi, Abdel Wahhab (1990), op. cit., p. 372.

232 Yinger, p. 186.

${ }^{233}$ Ibid.

${ }^{234}$ Lesch, op. cit., p. 31.
} 
himself or herself as a Muslim-Arab in social and political domains. ${ }^{235}$ This research argues that the interconnection of the Arab race and Islam in Sudan impedes some ethnic groups to embrace Islam. And at the same time; it can be assumed as an underlying stimulating factor for some Nubian ethnic group in Sudan to develop reconstruction of the new identity, after their conversion to Islam. Some of them have constructed an ancestral genealogy reaching back to an Arab descent. The reconstruction was invented to establish a kinship relationship with Arab tribes that retained a tradition of heroism in the distant nomadic battles in the Arabian Peninsula. According to Deng, construction of Islamic identity was indispensable to the new Muslims in Sudan. It was associated with the Arabic language and culture and established a new phase of living with the superior race, Arab and not only the religion, Islam. For this, many Nubians and other Blacks resorted to fabricate their genealogies to have an Arab origin. Some counted themselves as kin to the tribe of the Prophet Muhammad, the Quayrash to suit the required religious and ethnic identity. Hence, the intertwined Arabisation with Islamisation brought the current assumed descent identity in the North of Sudan contrary to its previous identity of religious and ethnic diversity. This group persistently reconstructs the diverse Sudan's societies along this indispensible Islamic-Arab model. ${ }^{236}$

${ }^{235}$ Idris, op. cit., p. 6.

${ }^{236}$ Deng, Francis Mading (1995), op. cit., pp. 194-195. 


\section{RECONSTRUCTION OF DIVERSITIES IN SUDAN}

Nationalism is a perceived conceptual political ideology that certain groups of people pursue in order to establish a sovereign territorial state for themselves. Nevertheless, within that territory, power endeavours to build institutions, but it encounters certain obstructions arising from the choice of multiple models to be adopted in building those institutions for citizens. In selection, one economic, ethnic, racial or religious model may influence power to adopt it as a pattern for constructing national identity in the constitution of a state. At this phase, conflicting controversies may arise and become the dominant phenomena between power and institutions and the relationship of some citizens with power may intensely shift from the status of political harmony to political crisis. $^{237}$

After the decolonisation of Sudan, power in the state strives to build national identity on the intertwined classical ideological category of Islamic Arabism. It is an ideological model that interlaces Islam and Arab as one entity. Prunier observes that the successive ruling Muslim Arab elite in control of power in Sudan, since independence conceive Islamisation of the territorial state as an instrument of Arabisation. ${ }^{238}$ Some Muslim Arab students consider this model a positive step and provide different reasons for it. Some articulate that their support to the model is an ideological one because; it helps in unifying the existing ethnic and religious diversities in Sudan. In practice, it has already homogenised the diverse Northern ethnic groups from the far north, the west, the east and the centre as one group known as 'Muslim Arabs of the Northern Sudan'. ${ }^{239}$ Others claim that the identity of these regions came to be one, because Islam is a religion which removes the divisions of people on ethnic lines. Therefore, each of these Islamic regions was transformed into an IslamicArab identity. Being a Muslim qualifies a non-Arab, but a Muslim to the identity of Arab race. ${ }^{240}$

\footnotetext{
${ }^{237}$ Fox, Jonathon (2004). Religion, Civilization, and Civil War 1945 through the New Millennium, New York: Lexington Book, p. 17.

${ }^{238}$ Prunier, Gerad (2004). "Rebel Movements and Proxy Warfare: Uganda, Sudan and the Congo (1986-99)", African Affairs, the Journal of the Royal African Society, Vol. 103, No. 412, pp.382.

${ }^{239}$ Muhammad el-Nur Shihab, Kawahla ethnic group, University of Khartoum states "We are Muslims and cannot be separated from Arabism our shared value".

${ }^{240}$ Lula Hassan, Omdurman Ahlia University from Hassaniya Arabs of el-Gezira, argues: "If you are a Muslim, then you cannot deny being an Arab. So, the west, east, centre and far north are inhabited by Muslims, thus, they are one, because, Islam and Arab are the identity. Wasilla Kababish, University of Khartoum argues: "We are one, because Islam was preached by an Arab who transformed us in faith into an Arab identity".
} 
The claim of some students that Islam transforms different ethnic groups into an Arab identity puts sociological study into a serious search for a model that could really constitute national identity. Studies of two scholars suggest an ethnic group as a principle constituent that constitutes national identity in a state, however, each of them presents different definitions for the term 'ethnic group'. First, Yinger limited his definition that ethnic group is a composition of people connected by supposed ties of blood manifested by community of language, religion, and customs and in turn, those supposed ties become the basic sources for the formation of a nation'. ${ }^{241}$ Second, for Barth, there is no specific constituent that constitutes national identity, beyond an ethnic group. This conclusion prompts him to define the ethnic group as a category, where its actors ascribe to themselves what they want as their distinctive national identity that distinguishes them from others. $^{242}$ This definition suggests that a group of people can take one of the supposed ties of ethnic groups such as 'language', 'religion' or customs and make it a model of its national identity. After the departure of all foreign systems which have ruled Sudan, power commenced to pursue this model in constructing Sudan's diverse identities. Idris argues that Muslim Arabs in Sudan control power and wealth and divide the population into the 'Civilised Muslim Arabs of the Northern Sudan' and the 'Black heathens' of the Southern Sudan. In practice, two models, Islam and Arab culture are introduced in institutions to become undividable entities and power applies them as one model in determining the identity of the state. Idris concludes that such a form of transformation of diverse identities promotes an exclusion of those defined as the "heathens", primitive and uncivilised in the South of the country. ${ }^{243}$

\subsection{Civilised Muslim Arabs of North Sudan and internal conflicts}

The territory of Muslim Arab Northern Sudan actually consists of heterogeneous ethnic groups, rather than, the homogeneous Arab race. It is a composition of the diverse Arabised ethnic groups that includes the Christian-Arab minority originally Egyptian Christians, Copts, and Syrian Christian Orthodox Church. Generally, this group of Arabs constitutes $40 \%$ of the total population of the whole country and it lives mostly at Gezira, north, centre, north of Kordofan, the southern Darfur and minority in Nuba Mountains and the east of Sudan. ${ }^{244}$ The Beja ethnic group with its

\footnotetext{
${ }^{241}$ Yinger, op. cit., p. 10.

${ }^{242}$ Barth, Fredrik (1969). Ethnic Groups Boundaries, Boston: Brown and Company, p. 10.

${ }^{243}$ Idris, op. cit., p. 15.

${ }^{244}$ Wai, Dunstan M (1980). "Pax Britannica and the Southern Sudan, the View from
} 
vast sub-ethnic divisions in eastern Sudan is Muslim, but distinct and represents 6\% of the total population of Sudan. There are extensive and diverse groups in Darfur and Nuba Mountains of the western Sudan. People of Darfur include, the Fur as a majority totaling $2 \%$ with minorities such as, Daju, Beigo, Zagahwa, Berti, Massaliet, Gimr, Tama and many others. ${ }^{245}$ The Nuba in the Nuba Mountains at the Southern Kordofan State represent 5\% of the total population. The Nuba are divided into more than fifty groups. ${ }^{246}$ Within western Sudan, there are West African immigrants, generally known Falata, which include Fulani, Hausa, Kanuri and Songhai and they represent 3\% of the population. ${ }^{247}$

Does the taking of the intertwined Islam and Arab race as one model for unifying these heterogeneous groups succeed in transforming different groups in Sudan to become one culturally? Whitehouse observes that a group of people may live within a territory of a state as one nation. Yet they are not one; certain cultural performances distinguish them as different groups. For instance, cultural practices of dance mark their distinctiveness of being different, because, dances reflect their unique diversity. Participants in each group in dancing dress in accordance with their cultural dress, while some may attire themselves in costumes and others dress with shells high hill shoes and others wear feathers. ${ }^{248}$

Cultural uniformity based on indispensable Islam and Arab models in Sudan reflects the same situation as Whitehouse describes it. First, practical cultural performances show that the Nuba groups within this territory called civilised Muslim Arab of North Sudan, display different symbolic references of uniqueness in their dances. Each one of them in the region follows its distinctive cultural and social performances, which are irrelevant to Arab culture. The Nuba students explain this situation as: 'The people of Nuba Mountains are identified through their different social or cultural dances. Some dances are annual, especially the dance of harvesting, but there are dances, which are played, after three years with exception of siber, a kind of a dance that is played after

The Theatre", African Affairs, the Journal of the Royal African Society, Vol. 79, No. 316, p. 375. See Wai (1980), op.cit. Northern Sudan comprises of Ja'aleen, Danagella, Hassaniya, Kawahla, Girma, Husainat, Juhyana, Kababish, Shukuriya, Baqqara (Silaim Hawazama, Missieria, Humr, Reizegat, T'aisha, Bani Rashid, Rashaida, and the Habaniya, Gezira state at the centre comprises Misslellimiya, Halawain, Rufa'a and Zabaidiya. There are Hawawir which includes Berbers of Hawawit, Jellaba, Hawara and Korobat. Mixed Arabs with Nubians, include Shaiqqiyyia Manasir, Rubatab and Mirifab. The Christian Arab minority includes Copts (Christian Egyptians) and Syrian Orthodox, p.17.

${ }^{245}$ Voll, John Obert and Sarah, Potts Voll (1985). Sudan: Unity and Diversity in a Multicultural State, Boulder: Westview, pp. 5, 13. Beja is composed of Beni Amer, Amarar, Bishareen and Hadendawa.

${ }^{246}$ Stevenson, R C (1984). The Nuba of Southern Kordofan, Ethnographic Survey, Khartoum: University of Khartoum Press, pp. 12-15. The Nuba include, Nyimang, Teimen, Kalta, tima, Tegali, Koalib- Moro Heiban, Shwai, Otoro, Tira, Moro, Daju, Tulishi, Keiga, Miri, Kadugli, Korongo, Talodi- Mesakin and many others,.

${ }^{247}$ Wai, Dunstan M (1980), op. cit., p. 17.

${ }^{248}$ Whitehouse, Harvey (1995). Inside the Cult Religious and Innovation Transformation in Papua New Guinea, Oxford: Clarendon, p. 13. 
every six years. Our cultural dances show that the Nuba are not part of the North of Muslim Arab' ${ }^{249}$ One of them from Muro section of the eastern Kadugli characterise the method of their dress during public dances as: 'We the Muro dress ... horns of animals on our heads and dress feathers and irons on our legs and ankles, during occasions of our dances'. ${ }^{250}$ One of them concludes that the Nuba are not Arabs and Arabs are not Nuba, so the annexation of the Nuba region to the constructed Northern Sudan of Muslim Arab and calling the Nuba as Arabs is wrong. He states: 'Our culture proves that we are not Arabs'. ${ }^{251}$

The narratives of the Nuba students about their cultural dance represent their resistance to the imposed dualistic model of Islamic Arabism that rejects the unique cultural identity of the Nuba people. It represents the conflict between the oppressive ideological force and the oppressed Nuba within the Northern Muslim Arab region. de Waal observes that dance, wrestling and musical performances in the Nuba Mountains attract the tourists into the region, but the ruling party, NCP in power categorises those cultural performances as non-Islamic and strives to impede them. On the other hand, the SPLM views them as manifestations of distinctive cultural identity which have made ethnographers to describe the Nuba as a distinct group and allows them to be revived in the region. $^{252}$

Generally, historical experiences show that Christian and Muslim missionaries attempted to control Africans by associating their traditional cults to Islam and Christianity. This form of control has caused controversy between the missionaries and the converted Africans to historical religions. As a matter of faith, the African religious group started to seek alternative resolutions to overcome cultural hegemony of foreign customs and traditions of Christianity and Islam. The result of the search led to the formation of independent African religious institutions apart from the national ones in Africa. According to Herskovits, the rejection of missionaries to the linking of African animistic religions to Christianity and Islam led to the foundation of independent African mixed religious centres with their own religious cults. ${ }^{253}$

At the present, some African Sudanese Muslim politicians issue statements which seem to suggest the promotion of founding independent Muslim religious associations connected to African

\footnotetext{
${ }^{249}$ Salah Tom, a Muslim Nuba, University of Khartoum.

${ }^{250}$ Abas Didi, a Muslim Nuba at Omdurman Ahlia University.

${ }^{251}$ Jamous Kuku, a Muslim Nuba at the University of Khartoum.

252 de Waal, Alex (ed.) (2004). Islamism and Its Enemies in Horn of Africa, Addis Ababa, Shama Books, p. 2.

${ }^{253}$ Herskovits, Melville J (1961). Human Factor in Changing Africa, Toronto: Alfred A. Knopf Inc, pp. 417-8.
} 
Animism. Yusuf Kuwa Makki, a Muslim politician from the Nuba Mountains ${ }^{254}$ asserts that the Nuba must resume their traditions of kujur (African religious rites). Yusuf concludes that in the Nuba Mountains people of kujur perform physical miracles which are difficult for our minds to comprehend and explain. ${ }^{255}$

In fact, Yusuf Kuwa Makki with some few Nuba rebelled in 1985 and joined the rebels' movements the SPLM and SPLA. These Nuba were trained in the rebels' camps and marched after military training with other trained Christian and Animist rebels from the South to the Nuba Mountains, under the battalion 'New Kush'. ${ }^{256}$

The name, 'Kush' is referred roughly to the northern part of present Sudan ${ }^{257}$ and its use by the rebels suggests a proposed new reconstruction of a new identity in opposition to the existing territorial identity, Islamic Arab North. It characterises a search of decision makers in search of identity. It indicates that Sudanese decision makers construct identity superficially that does not constitute tolerance to its diverse identity and each endeavours to reconstruct it. In practice, such instability revives constant and opposing social and political constructs based on Islamic and Arab traditions in conflict with the Christian and the African Animism. Iyob and Khadiagala argue that there is no clear programme by which the people of Sudan and the constant events they constructed could be identified, beyond, the binary racial categories in the public media of the African-Christian Animists of the South versus Muslim Arab in the North. Such opposing categorical constructions do not provide anything, since what are underlying the visible surface are complex and infinitely more revealing than all the superficial wisdom taken now as the truth. Iyob and Khadiagala conclude that "we offer an examination of historical myths, shifting identities, metaphors ... paradoxes constructed from ambiguous social understandings, confused beginnings, and uncertain endings all part of the extraordinary complexity that was, and still is, Sudan of today". 258

The description 'still is Sudan of today' is a reference that Sudan is stagnant in finding an encompassing system which its citizenry would embrace as a common source that represents them

\footnotetext{
${ }^{254}$ Meyer, Gabriel (2005). War and Faith in Sudan, Michigan: William B EErdmans Publishing Company, p. 3.

${ }^{255}$ Op’t End, Nanne (2001, February 12-13). “Interview with Yusuf Kuwa Mekki” Http://home.planet.nl/ende0098/Articles/20010426.htm.

${ }^{256}$ Rolandsen, Oystein H (2005). Guerrilla Government Political Changes in the Southern Sudan during the 1990s, Uppsala: Nordiska Afrikan Institutet, p. 98.

${ }^{257}$ de Waal, Alex (2006, December 22). "Averting Genocide in the Nuba Mountains, Sudan”, http: //howgenocidesend.ssrc.org/de_waal2/printable.html. Residents of the Old Northern Sudan of Nubia knew themselves as Kush.

${ }^{258}$ Iyob and Khadiagala, op. cit., p. 19.
} 
as their national identity. This political stagnancy continues to function, under the binaries of favour and discrimination of the citizens in public structures. Recent political developments within the institutions of the constructed territorial identity as the civilised 'Northern Sudan Region' that comprises the far north, the east and the west of $\operatorname{Sudan}^{259}$ show that the model is not functioning within the national institutions of the region. Sociologically, a functional society manifests its interrelated structures in established economic, political and social institutions. Each of these institutions has a function that contributes to the overall stability and sustainability of the social system in the territorial sovereignty of a state. ${ }^{260}$ The present political violence within the IslamicNorthern Sudan Region demonstrates the disintegration of its inter-related institutions. In its current institutions, ethnic categories and colour dominate more than the religion, Islam. The comparison is carried to the religion, where the indigenous African Muslims in the Nuba Mountains, Darfur and the Beja are not equal with the people of Arab-Muslim origin in different public institutions. Religion does not determine their social status, instead, their ethnic backgrounds as non-Arabs. Prunier asks the question, how could a new war conflict be developing in a region wholly populated by Muslims when it was known by everyone that the war in Sudan was between the Arab Muslims in the North and the Southern-African Christians in the South? Prunier concludes that by the summer 2004, a sinister term of racism was a dominant description of violence within the Islamic North between the native people of Darfur and the Government of Sudan with its Arab Muslim militia fighting the Darfurian indigenous Muslims. ${ }^{261}$

\subsubsection{Discrimination against the Nuba}

A Nuba student states: "The name Nuba is a strange name; it does not exist in our villages. The name is foreign to us; we ... come to know it; after we came to Dalenj and Kadugli towns that we, the Black population residing in the extensive mountainous region of approximately ninety nine mountains are called Nuba. At past, I hate it, because, it was a name constructed by Muslim Arab slavers. At present, the term has shifted to the status of our nationalism, so many of us start to accept it and we are Nuba". ${ }^{262}$ Many Nuba students are Muslims; nevertheless, they argue that Muslim Arabs discriminate against them in social structures in a similar way as they do against the

\footnotetext{
${ }^{259}$ Idris, op. cit., p. 15.

${ }^{260}$ Smith, Anthony D (1986). The Ethnic Origins of Nations, New York: Blackwell, p. 5.

${ }^{261}$ Prunier Gerard, op.cit., pp. vii 77.

262 S. A.
} 
Christians and the Animists of Nuba Mountains. They present their arguments as: 'we are treated as dhimmis (protected non-Muslim groups residing in the land of Muslims) within one religion, Islam by the Muslim Arabs'. ${ }^{263}$ 'When a Muslim Arab takes power militarily in Sudan, then Arabs rally behind him, and when a Nuba Muslim does the same action, then the Arabs would say who will clean the toilets. This is to mean the Nuba are second-class citizens and are expected to engage in marginal professions in Sudan'. The student concludes by presenting a question; 'so, how do we become one, under this clear racism?' ${ }^{264}$ According to Lesch, the Nuba people adhere to Christianity, Islam and Animism. Yet, the tension between them and Muslim Arabs in control of power and resources remains largely intense. The Nuba complain that the state treats them as "second-class citizens" 265 equal to the Dhimmis, even though, the majority of them are converted to Islam and quite assimilated to the Arab cultural identity ${ }^{266}$

Experiences of some Muslim Nuba people with Muslim Arabs in the region reveal the existing discrimination based on the belief in an Islamic North among the Muslims. African News interviewed Yusuf Kuwa Makki and claimed that the majority of Muslim Arabs in Sudan believe that angels in paradise are divided into black angels and white angels. These angels receive the dead in accordance to their colour. Black angels receive the black souls of Animists and throw them into hell and the light-skinned angels receive the Muslims and take them to heaven. ${ }^{267}$

Consistent discrimination by Muslim Arabs towards Muslim Africans in Sudan has also been experienced by another Black Muslim leader, Ali Abdel al-Latif. According to Idris, during the formation of Sudanese nationalism, the issue of race and ethnic descent became the crucial determining factor in politics of building the nation state. 'Being an Arab' was more important than being a Muslim. Abdel al-Latif, a Muslim from the Dinka ethnic group was not a true representative of Muslims in the thinking of the Northern Muslim political leaders. The leader of the Muslim Ansaar sect, Abd al-Rahaman al-Mahdi described him as a self-representative figure and not a representative of the nation. Idris concludes that this racial description was projected in Muslim Arab public media such that: "low is the nation if it can be led by Ali Abdel al-Latif", a Black slave. $^{268}$

${ }^{263}$ Salah Mustafa, at the University of Khartoum.

${ }^{264}$ Naima Muhammad Abdel Aziz, Omdurman Ahlia University.

265 Lesch, op. cit., p. 35.

266 Ibid.

${ }^{267}$ African News (2001, April). "Yusuf Kuwa Makki, Life is a School with Great Lesson”, African News, Issue 6, p. 2.

${ }^{268}$ Idris, op. cit., p. 83. 
Currently, some leaders in the Nuba Mountains claim that the Government of Sudan mixes religion, Islam with the Arab race. Educational opportunities for a Nuba are conditional. First, a Nuba must convert from Animism or Christianity to Islam. After the conversion to Islam, then the condition of adopting an Arab name comes up. Simon Karlo, a Nuba politician has experienced this conditions and states "I embraced Islam myself, when I was a pupil at the primary school and changed my name to Ismail, otherwise, I would have not finalised my education". ${ }^{269}$ One of the questions posed in the questionnaires was: "How conversion from one religion to another religion in Sudan is conducted; do you encounter an obstruction on the process and have you ever felt that there has been an interference of your ethnic customs, cultures and traditions to your religion, if yes, please explain?" One Muslim Nuba student provides an explanation to the question as "the obligatory method of conversion to Islam is that a person must testify 'there is no god but God, and Muhammad is the Prophet of God'. That testimony originated from the Holy Quran, but in Sudan race interferes with this method of conversion, meanwhile, God in the Holy book, Quran does not require a Nuba to testify an Arab race, but Muslim Arabs in Sudan feel very comfortable to see Nuba Muslims changing their names to Arab names. This testimony is universal, it dictates a believer to recognise the unity of being and there is no instruction that dictates a converter to change an original name into an Arab Name. ${ }^{270}$ One Muslim student concludes 'indeed, this religion, Islam is innocent from this indispensability of Islam and Arab; it is power of Muslim Arabs in Sudan which adheres to this ideology in order to maintain marginalisation of Muslims of non-Arab origins and not Islam. ${ }^{271}$

\subsubsection{Resistance against marginalisation}

Amal Muhammad, a Nuba Muslim student believes that government authority in any state is an essential source of power and has been expecting government to operate as a tool for the realisation of prosperity for the people of Sudan as one nation. In her view, Sudanese political parties that inherited power from the colonial system of Great Britain practice it in a way that does not reflect this aspiration. The student argues that, during the national struggle for the independence, two political slogans 'equality' and 'prosperity' were the dominant claims advertised by political

\footnotetext{
${ }^{269}$ AFP (2001). "Simon Karlo, Director of Education in Nuba Mountains", Agence France Press, p. 4.

${ }^{270}$ Kuku al-Lamin claims that his father gave him his family name but that could not work with a teacher at the primary school in Dalenj and 'had to choose another name so that it fits in the system.

${ }^{271}$ Amal Muhammed at the University of Khartoum.
} 
parties. Post independence, contradictions between these slogans and performances of the successive governments dominate institutions. Two religious sectarian groups, the Umma and DUP inherited power in the country and marginalised the people at the peripheries of the Nuba Mountains, South Sudan, Darfur, Beja and Ingessana Hills. ${ }^{272}$

The history of power sharing and violence in Sudan shows that the Nuba were quick to introduce the process of rectifying political marginalisation in two ways. First they tried a democratic pluralistic approach, thus, in 1964 the Nuba formed an association 'General Union of the Nuba Mountains' (GUN). An objective of the GUN was to build a political consciousness among the Nuba and demand their economic and political rights from the Government of Sudan. The terms of this objective were defined and clandestinely circulated. The Umma and the DUP parties were branded as sources of political and economic marginalisation of the Nuba people and that required an objective approach to combat it. ${ }^{273}$

The objective approach to political marginalisation could not be achieved; thus, the Nuba turned to violence to re-address political grievances between them and the Jellaba. The Nuba students explain: 'the manifesto of the SPLM calls for the introduction of political equality and the adoption of a constitutional system that considers ethnic and religious pluralism in the state as a source of legal codes in the country'. ${ }^{274}$ Another one states: "In early 1987, the manifesto satisfied us as the members of Komolo, an underground political organisation of the Nuba Youth ... that used to operate in social institutions and yet we continued to define that religion, Islam is innocent of the existing inequality and started to influence the intellectual group from the Nuba to join the SPLM and SPLA ${ }^{275}$. One of them concludes: 'We recruited and delegated them to the training camps at the western Ethiopia. After the military training, they returned as armed forces and commenced to attack the military installations of the government in our region, Nuba Mountains. The combatants raised the slogan that religion, Islam was innocent in the violence and maintain the respect to religious centres of Islamic symbols as divine sites for all Muslims, Christians and Animists. Many from the Nuba continued to join the rebel military training within South Sudan and western Ethiopia'. ${ }^{276}$ Suliman enumerates that the Nuba feel dissatisfied politically with the 'Jellaba', a

\footnotetext{
${ }^{272}$ Intisar Ahmed, a Muslim at the University Khartoum.

${ }^{273}$ Op’t Ende, Nanne, op. cit., "Governor of the Nuba Mountains, Yusuf Kuwa Mekki”, p. 4. Http://home.planet.nl/ende0098/Articles/20010426.htm.

${ }^{274}$ Musa Kuku, University of Juba.

${ }^{275}$ Sana Ibrahim, University of Khartoum.

${ }^{276}$ A N Nuba, Omdurman Ahlia University.
} 
term that identifies Muslim Arab officials and traders from the indigenous population in Nuba Mountains. The Nuba accuse the Jellaba of marginalising them in distribution of power and wealth and they intend to re-address this marginalisation with all available options, therefore, many of them joined the SPLA and SPLM. ${ }^{277}$

\subsubsection{Innocence of Islam and Conflict between the Church and the Government}

It is worthwhile to analyse the political performances of the government within the Nuba Mountains region. Its performance will show us the nature of social relationships of the people in the region and the role of politics towards these relationships. It is through these relationships where we could infer the 'innocence' of the religion Islam which some Nuba students emphasise and accuse the Jellaba of resisting the application of its precepts into institutions. First, some Nuba students argue that 'our social relationships with the Jellaba, Hawazama and Missieria have been very peaceful for a century. Our current deadly wars are influenced by Khartoum'. 278 'The Arabs Muslims in power know that the majority of the Nuba are Muslims, but power does not care about the religion, it does not care about its values of equality and justice for all Muslims. ${ }^{279}$ Instead, it favours 'the Arab Muslims and arms them to kill us claiming that we support the SPLA'. ${ }^{280}$

In comparison, some Jellaba students stress their opposite arguments: 'our ancestors have lived with the Nuba in the Nuba Mountains for over a century in peaceful relationships with each other and abruptly some problems which were not political came up and polluted our relationships. In this way, we neglected our religion, Islam which unifies us and we resorted to race, because the Nuba performances demonstrate enmity. This behaviour developed to hatred and disaster, but different governments in Khartoum have not presented solutions, instead they behave in a way that fans racial conflicts between us and the Nuba'. ${ }^{281}$ According to Suliman, in the past, some problems related to water and land occurred between the indigenous Nuba and the new settlers, the Jellaba. These problems were easily addressed at annual conferences composed of the Nuba mekks (Muslim Nuba leaders) and the Arab sheikhs (Islamic Arab leaders). The two parties abided by the resolutions reached in these conferences and peace and prosperity was maintained. In reaction against the insurgents of the SPLA, the government sought to make the Jellaba in the region as its

\footnotetext{
${ }^{277}$ Suliman, Mohamed (ed.) (1999). Ecology Politics and Violence Conflict, London: Zed Book, p. 4.

278 Tarile Ahmed, University of Juba.

${ }^{279}$ Amar Hamdan, University of Khartoum.

${ }^{280}$ Muhasen Sadiq, University of Khartoum.

${ }^{281}$ Mohammad Saleh Ahmed, University of Khartoum, Faisal Muktar, university of Khartoum.
} 
proxy fighters to fight the rebels. Suliman concludes that the government combined forces of the para-military and regular soldiers have not spared the Nuba civilians from the violence; thus their villages became the targets and they were uprooted. ${ }^{282}$

Taking into account some students claimed experiences the recruitment policy of the government was based on discrimination. It recruited the Jellaba as a militia with the intention of fighting the SPLA and Muslim Nuba who were interested to join the militia experienced exclusion from recruitment. This exclusion jeopardised the Nuba civilians to a vulnerable situation, where they became the immediate targets of the Jellaba militia. The Nuba students explain this phenomenon as 'during the war, the militia composed of Missieria and Hawazama targeted us. It launched attacks against our traditional residential areas, killed, looted, and burnt the houses'. ${ }^{283}$ 'Since 1986 to the present moment, the governments in Khartoum based their recruitments of militia on the basis of race'. ${ }^{284}$ 'In 1987, some Nuba whom I know ... tried to join the militia that was intended for the population of the region to defend itself from any armed interfering forces into their civil institutions. Young Nuba who went and registered for recruitment in the militia in the cities of Kadugli, Talodi and Dalenj were rejected and their cohort Muslim Arabs were armed and given weapons ${ }^{285}$. These recruited 'Muslim Arab militias had not seen us as equal Muslims, but chose havoc, terror and killing of Muslim Nuba, Animists and Christians at their... residential areas, ${ }^{286}$. One of them concludes 'the killing of a Muslim Nuba at their homes was not an Islamic way, our religion; Islam is innocent from this discrimination'. ${ }^{287}$ African Rights reports that the SPLA made its first incursion into the Nuba Mountains in July 1985. In response, the government began to arm the Baqqara Arabs as a militia against the Nuba. The Minister of Defence, Fadalla Burma Nasir from Missieria Arab armed the Baqqara Arab of Humr, Missieria and Zurug. The Nuba civilians called this militia, muraheleen, a term that refers to the nomad Baqqara Arabs. This group revealed its hidden agenda that appeared, during its military operations. It wiped out the Nuba from their traditional lands and looted their properties. ${ }^{288}$

\footnotetext{
${ }^{282}$ Suliman, Mohamed (1999), op. cit., pp. 7- 9.

${ }^{283}$ Ibrahim Sultan, University of Juba.

${ }^{284}$ Talah Adam, University of Juba.

${ }^{285}$ Hind Hamza. University of Juba.

${ }^{286}$ Memi Ahmed, University of Khartoum.

${ }^{287}$ M Jamal Jezuli, Omdurman Ahlia University.

${ }^{288}$ African Rights (1995). Facing Genocide: The Nuba of Sudan, London: African Rights Publication, p. 118.
} 
Some scholars thought that the situation would change in the Nuba Mountains after the restoration of a democratic multi-party government in April 1986. In the opinion of Mahmud and Baldo, the people of Sudan expected that the Prime Minister, Sadiq Al-Mahdi from the Umma Party would restore stability to the vulnerable Nuba area suffering from the muraheleen. Instead, the Premier promoted the role of the Baqqara in the Nuba Mountains. He maintained Fadalla Burma Nasir, a Baqqara and Former Minister of Defence of the Transitional Military Command Council of 1985 as a Minister for Defence in his government. Nasir aggravated the recruitment of the ethnic Arabs from Baqqara into the militia which in turn launched indiscriminate assaults against the Nuba. ${ }^{289}$

This scenario of racial conflict against the Nuba remained unchanged and escalated after 1989, when the Salvation Revolution captured power by force from the democratically elected government claiming that it wanted to protect Sharia as a law for the people of Sudan. At this time, some Sudanese Christian religious leaders such as the Catholic Bishop Macram Max Gassis of the El-Obeid Diocese became outspoken critic of the Salvation regime. The Bishop alleged that the Salvation Revolution had dismantled the democratic system claiming that it wanted to protect Sharia. Under Sharia, the 'Salvation Revolution' was responsible for terror, assassinations, genocide, ethnic cleansing, torture, mass-arrests, extrajudicial executions and religious persecution in Sudan. He concluded that the Church must extend its voice to be heard on behalf of the people of Nuba Mountains as they have been absolutely neglected in the world media. ${ }^{290}$

This Christian rhetoric creates an image of two opposing camps: the camp of the Christian Church and the camp of the government represented by the Islamists of the Salvation Revolution. These two parties develop incompatible claims on the people of Sudan in general. The institution of the Church constructs itself as the rightful defender of the people of the Nuba Mountains in particular. On the contrary, the government claims absolute responsibility over the citizens and rejects any involvement of other bodies. These contesting claims cannot be justified; however, an analysis of the nature of each claim through certain services of each to the destitute Nuba may be a principal tool for justification. An equal healthy treatment of any form of power collectively in a political or social space with valuable series of service delivery, during a physical disaster constitutes chances of a certain degree of confident and willing relationships. The question on the questionnaires is

\footnotetext{
${ }^{289}$ Mahmud, Ushari Ahmed and Baldo, Suleyman Ali (1987). The Dhein Massacre Slavery in the Sudan, London: Sudan Relief and Rehabilitation Association, p. 26.

${ }^{290}$ Gassis, Macram Max in Mayo, David (ed.) (Autumn 1994). "The Sudan Cincinnati Reaches out to Sudan”, Newsletter, University of Pennsylvania, African Studies Center, Vol. 4, p. 12.
} 
religion important ... provides some clear role of the Church to the Nuba. Students of the Nuba explain: 'religions, Islam and Christianity, are very significant to humanity. First, without the Church, our suffering at the hands of Muslim Arabs would have not been unfolded to the American people'. 291 'There was no any Islamic state that had bothered itself, when the National Islamic Front Government, known now as Salvation Revolution imposed Jihad on us; even though many of us are Muslims. Churches in America understand humanity, a very rare quality in our Islamic setting in Sudan'. ${ }^{292}$ According to Meyer, after the news of the government-sponsored Jihadist attacks against its own citizens in Nuba Mountains in 1992, the Nuba were heard in the United States. An American Pastor, Tom Tiscornia moved with his personnel to the area to pay their respects to the Nuba families who had lost their loved ones. At the same time, the Catholic Church delegated David Coffey of Montgomery, Alabama as a Representative of Bethlehem, a Pennsylvania-based Catholic Medical Foundation to dispatch donations collected by Bishop Macram Max Gassis from American citizens to the people of the Nuba Mountains. ${ }^{293}$

In contrast, some Muslim Arab students argue: "What do you do with those Muslims who object to the dominance of Sharia as the law that God dictates". ${ }^{294}$ Another respondent said: "The Nuba were attacked because of their rebellion and it was a duty of a responsible government to get rid of those rejecting the adoption of Sharia: ${ }^{295}$ One of them concluded: "Conspiracy of the West against Sharia stimulated the Nuba to reject the law of their faith and cooperated with the infidels from the South. The consequence was to fight them as apostates who have gone astray from the right path of God". 296

Muslims fighting other Muslims, because of religious opinion represent religious intolerance which is a topic some students have emphasised in their responses to the questionnaires. For instance, the question in the questionnaires "How conversion from one religion to another religion in Sudan is conducted; do you encounter an obstruction on the process and have you ever felt that there has been an interference of your ethnic customs, cultures and traditions to your religion, if yes, please explain?" Some Muslim students who have answered this question allege that the government of Sudan controls power and promotes intolerance against the people of other religions.

\footnotetext{
${ }^{291}$ Z A S at the University of Khartoum.

${ }^{292}$ M M, University of Juba.

${ }^{293}$ Meyer op. cit., pp. 13, 37.

294 Jafer Ahmed, University of Khartoum.

${ }^{295}$ M A I, University of Khartoum.

${ }^{296}$ Hashim Muhammad, University of Khartoum.
} 
It orients its adherents to reject religious freedom; meanwhile Islam decrees that no compulsion in religion. ${ }^{297}$ It strives to create all possibilities of imposing Islam and eradicating other religious faiths. ${ }^{298}$ One of them concludes: 'brother denounced Islam and became a Christian in 2001 and the government wanted to kill him, because of his new faith and we wanted him to live, because it was not our basic problem, since religion is one. ${ }^{299}$ According to Mahmoud, the leading figure in the government of Sudan Hassan Abdullah Turabi of the NIF party uses religion, Islam in order to convince Muslims to support the legitimacy of his Islamic system of the Salvation Revolution. For example, Turabi constructed the conflict in the South as a religious one in order to rally Muslim people behind his government. He helped to Islamise it and invited the Muslims of the Northern Sudan to participate in this war, under the slogan of Jihad against the opposition of the Nuba people in the region. Mahmoud concludes that the NIF promotes intolerance against other religions. ${ }^{300}$

Generally, experience shows that a mixing religious faith with politics creates uncertain political institutions, in regards to religious tolerance. It divides people within a territory into political religious associations. This usually happens under the influence of the interest political group, who may adopt religion as a means of manipulating their followers to implement their political aims. Such religious structure promotes religious intolerance at different stages. ${ }^{301}$

\subsubsection{Darfur and the origin of religious (in)tolerance}

Darfur is a composition of two words: 'Dar' means a space of a land inhabited by a group under a specific leader and 'Fur' refers to an ethnic group, Fur. This group occupies the central highlands and is dominant in local political and economic life in the region. It has sub-tribal divisions that include the Masabat, Kunjara and Keira. ${ }^{302}$ The Muslim Sultanate promoted Islam largely to be adopted in the territory as a model of national identity. During the era of Suleiman Solongdungo from Keira, religious practices related to Animism were forbidden in all social institutions and

${ }^{297}$ A S S, Omdurman Ahlia University.

${ }^{298}$ S M S, University of Khartoum.

${ }^{299}$ W A, University of Khartoum.

${ }^{300}$ Mahmoud, Mohammad (1997, September 16-17). "Islam and Islamization in Sudan: The Islamic National Front”, a paper Presented at a Conference on "Religion, Nationalism and Peace in Sudan", Washington DC: The United States Institute of Peace, p. 3.

${ }^{301}$ Van der Veer, Peter (1994). Religious Nationalism. Hindus and Muslims in India, Berkeley: University of California Press, p. 131. Lal Kishan Advani of the Indian People's Party, BJP with Vishva Hindu Parishad, VHP led a procession against the Muslim minority mosque in Ayodhya claiming the temple and violence broke out between them and Muslim minority; still India remains a state of religious diversity.

302 Badal, Raphael K (2006, May). "Traditional Resolutions of Local Conflicts in Dar Fur", Mahawer, a Journal for Sudanese Studies, Issue No. 13, pp. 7-8. 
Islam was proclaimed to be the only official religion in the region. ${ }^{303}$ Yet, the scale of conversion was low and his grandson, Sultan Ahmed Bakr introduced measures of conversion from Animism to Islam. He erected mosques, imported Arab teachers of Islam and compelled the Fur to disassociate themselves from Animism and adhere only to Islam. ${ }^{304}$

Those in Darfur who became Muslims began in time to view others who remained Animists as 'lost brothers' on the way to heaven. These sentiments can be found in the responses to the question: "What do you think about the people in Sudan who follow other religious faith and traditional rituals than yours, and please state the reason(s) of why you think so?" Some Muslim students offer lamenting responses such as: "In the beginning I thought Islam had extirpated racial divisions between Muslim Arabs and Muslim indigenous Africans of Darfur. Our former Kings brought Islamic Arab teachers and converted us to Islam and we thought we were brothers in Islam". ${ }^{305}$ The students continue: "Today, the majority of the indigenous people of Darfur came to observe that we were lost; Arab Muslims are not ... brothers in religion". 306 "The Arab League, mostly composed of the Muslim majority as a political regional agency stands on equal political footing with the regime in Khartoum that discriminates against us and kills us ... because we are not Arabs, but African Muslims of Darfur". 307 "Many of us in the past assumed that the Christians from the South were lost brothers from true religion, Islam."308 "Now, experience of this racial war has provided us consciousness, and indeed, our brothers in the South ... were not lost, but, they are our brother African Christians"309 "For the Arab Islamic regime in Khartoum with its janjaweed, the United States of America is a land of lost devils, since, it is a Christian country, but it is not conceived like that in Darfur, we know their identity. The Americans are angels; they value humanity to the certain degree of defending us from Arabs. Without Christian Americans pressing the government to cease its indiscriminate aerial bombardments, there would have been no indigenous population of Darfur at the IDPs camps of Kalma, Zamzam, Otash and Abu Shouk of Darfur". 310

\footnotetext{
${ }^{303}$ Iyob and Khadiagala, op. cit., p. 137.

${ }^{304}$ de Waal, Alex (2005 January). "Briefing: Darfur, Sudan: Prospects for Peace", African Affairs, the Royal African Society, Vol. 104, No. 114, p. 129.

305 Adam Shoukuri, University of Juba.

${ }^{306}$ Halima Ismael from Zagahwa, University of Juba.

${ }^{307}$ Ibrahim Hamed a Massaliet, Omdurman Ahlia University.

${ }^{308}$ Muhammad el-Affendi, a Fur, University of Juba.

${ }^{309}$ Hamed el-Taib Baldo, a Fur, University of Khartoum.

${ }^{310}$ Aisha Awad Muhammad, a Fur, University of Khartoum.
} 
These expressions from Muslim indigenous students of Darfur demonstrate the scale of dynamic racism. They epitomise a paradigm that whenever racism is embedded in national institutions against a certain group, then the search for the production of a new identity becomes inevitable. The victims of racism search for new cultural identity and reject the existing dominant one. Today, there is a public alarm from the international community to deploy an international reliable force in Darfur in order to protect the civilians from the violence between the indigenous rebels and the Government of Sudan. The civil society of these Muslim indigenous people of Darfur is badly affected by the violence and many regard African Union (AU) force in their region as an insufficient organisation to shelter them from the Arab Muslim-sponsored militia, the janjaweed as well as the government forces. The situation demands the deployment of a well equipped international force in the region. ${ }^{311}$ Despite this alarming situation, Muslim Arab countries and the Arab League (AL) resist this demand. The AL supports the deployment of this force, but insists that it should be under the directives of the AU which it describes as the only viable security organisation for the Darfur crisis. For years, the policy of the AL has been completely in line with the official Sudanese government position rejecting any other international force to help in stopping the massacre of the Muslim indigenous civilians in Darfur. ${ }^{312}$

\subsubsection{Territorial and power reconstructions in Darfur}

Muslim Arab students from other regions claim that Darfur is undeveloped compared to other regions within the Northern Sudan. ${ }^{313}$ On the other hand, some Darfurian Muslim students argue that: 'after the annexation of our region to the Nile Sudan, it has experienced systematically a serious marginalisation in terms of power and wealth. Many of us have witnessed ... the exclusive policies of Arabs in Sudan; our people know that the central Government of Sudan excludes our region, 314 . Another student states: "The perspective of wealth and power marginalisation ... stimulates the majority of our indigenous population to define themselves as outsiders in the territory of Sudan. Economic exclusion makes us feel not a part of Sudan; indeed, we are not part of... Sudan". ${ }^{315}$ One Fur student concluded that: 'some of us never know that we belong to the

\footnotetext{
${ }^{311}$ Iyob and Khadiagala, op. cit., p. 79.

312 Al-Hayat (2007, March 21). "About the Arab Stance vis-à-vis Darfur”, Al-Hayat English Version, p. 1.

${ }^{313}$ Mahmoud Sadig a Shaiqqiyyia Arab, University of Khartoum argues: "Darfur is equal with other regions which are not developed such as Berber at the far north. Every part of the Northern region is undeveloped".

${ }^{314}$ Eleham Majid Abdullah, a Zagahwa, University of Khartoum.

${ }^{315}$ Mahjoub Yasin Ahmed, University of Khartoum.
} 
territorial sovereignty of Sudan, instead, Khartoum is the Sudan and some know it, yet they want to be counted out from the territory'.316

Some central claims of this student invite analysis. First, the claim that some indigenous ethnic groups in Darfur have no knowledge that their region is part of the territorial Sudan denotes a typical territorial economic exclusion. Under this dissatisfaction, some citizens of the marginalised region define their territorial identity off the territorial map. Bush notes that the Darfurians in Nyala, capital city of the Southern Darfur with a huge population of Fur say that: "the train has come from Sudan", when in essence the train came from Khartoum the capital city of Sudan. ${ }^{317}$ Second, the claim that some Darfurians know that they belong to the territorial Sudan, yet they exclude themselves from any Sudanese territorial national identity is a crucial political vision. It represents a search for an independent autonomous region. Karklins observes that, when a regime in a multi-ethnic base structure fails to address the diverse interests of the pluralistic ethnic groups, the latter urge for more an autonomous territorial system or a total fragmentation of a territory into new sovereignties. $^{318}$

Historically, Darfur was annexed to the British protectorate of Sudan only in $1916^{319}$ and from that time until today, the region remains undeveloped. Frequent visits of the author to the area have shown that Darfur covers an estimated area of about 190, 420 square miles and visibly remains completely without virtual communications of roads that can connect its population. With its fragile ecology, deep boreholes and some few oases are the main sources of water. In economic terms, most Darfurians, especially the Fur rely on agriculture and the occasionally prolonged drought accelerates desertification, where most of the lands are covered by cactuses. And due to this natural circumstance, the nature of their land fits with some specific crops and fruits which resist drought such as millet and melon, particularly cantaloupe. Yet, all require a minimum of rainfall in order to be fully ripened. Lack of sufficient rainfall subjects the region to famine and death of cattle mostly belonging to the Zagahwa ethnic group.

\footnotetext{
${ }^{316}$ Ibtisam al- Amin from Fur at University of Juba.

${ }^{317}$ Bush, Ray (1988). "Hunger in Sudan: The Case of Darfur", African Affairs, the Journal of the Royal African Society, Vol. 87, No. 346, p. 5.

${ }^{318}$ Karklins, Rasma (1994). Ethnopolitics and Transition to Democracy: The Collapse of USSR and Latvia, Washington: Woodrow Wilson Center Press, pp. 9, 117.

${ }^{319}$ de Waal, Alex (2005 January). "Briefing: Darfur, Sudan: Prospects for Peace", African Affairs, the Royal African Society, Vol. 104, No. 114, p. 129.
} 
In the view of some indigenous students from Fur, Zagahwa and Massaliet of Darfur, the latest famines have a connection to the present war in Darfur. They regard the starvation of their people as neglect of the central government, under the "dominance of Muslim Arabs". ${ }^{320}$ According to Bush, during the last century, Darfur had experienced starvation and death of animals five times, due to the shortages in rainfall. In 1982 the same phenomenon occurred and the former Governor of Darfur, Ahmed Dereige from Fur cautioned the central government about the scarcity of rainfall. Dereige warned that such shortages would cause a severe famine and urged the government to declare Darfur to the international community as a humanitarian disaster zone, so that emergency aid could quickly reach the region. President Nimeiri rejected the request and denied the humanitarian organisations access to the area. This denial caused disputes between the Governor and the President, and the former resigned. ${ }^{321}$

The experience of famine in Darfur reveals that an emergency situation constructs two forms of leadership quality of authority in a state. First, the sympathetic leadership refers to the authority that cautions decision-makers to declare a danger to the public in search of humanitarian aid. Second, the parasympathetic leadership is referred to the authority that rejects the promulgation of a danger to an international community to attract humanitarian aid; instead, it endures its painful effect that may lead to fatality. ${ }^{322}$ The famine threatened the life of the indigenous Darfurians. Lesch explains that some emaciated escapees from the famine managed to reach Khartoum and camped in the suburbs of Omdurman. In reaction, the authorities in the capital introduced kasha, a legal measure that authorised police forces to roam vigilantly on streets of Khartoum, Omdurman and Bahri to detain the people of Darfur, South Sudan, and Nuba Mountains who lived there without professional identity cards. The destitute Darfurians were evicted from their camps and forcedly put into several train wagons and sent back to Darfur. ${ }^{323}$

Kasha can be defined in accordance to the nature of its application as cleansing, removing, expelling and uprooting unwanted groups from Khartoum, the surrounding cities and suburbs. Ahmed Dereige, however, retaliated against the ' $k a s h a$ ' by collecting people of Arab origin from

\footnotetext{
${ }^{320}$ Hamdan Eisa, aFur, University of Bahr el Ghazal. Iyahab Osman, a Massaliet, University of Khartoum. Lula Ali Sadiqq, Zagahwa, University of Khartoum.

${ }^{321}$ Bush, op. cit., p. 7.

${ }^{322}$ Karn, Harry W. and Weitz, Joseph (1955). An Introduction to Psychology, New York: John Willey \& Sons INC, p. 171. A reaction of a person to a situation is determined by sympathetic, where the autonomic nervous system releases sufficient amount of hormones into the nervous system to escape a threat. Parasympathetic refers to a situation, where the autonomic nervous system controls the flow of hormones to escape a threat.

${ }^{323}$ Ibid.
} 
Darfur, loaded them into train wagons and sent them to Khartoum. ${ }^{324}$ Most importantly, the application of kasha reconstructs two territorial boundaries of residence within one sovereign state of Sudan. First, the north of Sudan that includes the capital city Khartoum, Omdurman, Bahri and other nearby cities, where the specific ethnic groups are reconstructed aliens and unwanted. On the other hand, it constructs Darfur as a territory, where some specific race, a Muslim Arab from the northern part of Sudan is an intruder into the area and, must be deported to his or her territory, Khartoum.

These territorial reconstructions to the citizens and other political disputes between powers of Darfur and Khartoum developed, leading to the resignation of the Darfur Governor and who into exile. The resigned Governor, Dereige explains that he left the Governor Position of Darfur, because of two issues: first, the refusal of the Nimeiri regime to declare Darfur as a disastrous zone of famine, and second, because of the new Islamic fundamentalism that led to the imposition of Sharia which prohibits alcohol. He argues "I consider alcohol as a symbol of freedom in the country for the citizens ... to choose between drinking and abstaining". ${ }^{325}$ Dereige concludes while in exile, he with others revived struggle that aims to eradicate the marginalisation of Darfur in wealth and power sharing. ${ }^{326}$

\subsubsection{Ideological conflicts and racism in Darfur}

Most Muslim students from the indigenous population of Darfur acknowledge that Islam has had success in homogenising parts of Sudan, including their region, Darfur, but the contradictory political approaches of the successive central governments revive ethnic lines. Responses to the question: "How did the east, west, far north and centre become the Northern Sudan, in exclusion of the South and what does the name of your region and Sudan mean in your native language and do you experience any difficulty in articulating it ? Responses to this question provide the reason for political Islam. Islam was developed as an ideology for creating a majority of a political umma (nation of Islam) to overshadow the conservative traditional African Muslims, Christians and Animists in Sudan. The students enumerate this situation as: 'Islam has really united us, but Arabs changed it for their political egoism to deny our majority as African Muslims, Christians and

\footnotetext{
${ }^{324}$ Lesch, op. cit., p. 53.

${ }^{325}$ Al-Waton (2008, December 4). "Al-Hokuma al-Sudania Ger Jada wa la Teltezem be-Itifaggiataha, "The Government of Sudan Is not Genuine and Does not Honour Agreements", Arabic Newspaper, Al-Waton, Issue,782, p. 3. ${ }^{326}$ Ibid.
} 
Animists in Sudan.' 327 'We have just discovered that we have been deceived in the beginning to drop our ethnic affiliations to create umma, but we have known now that different regimes, under the control of Muslim Arabs in Khartoum made it as a means of creating political majority, but not Islam'. ${ }^{328}$ 'It is true that Arabs are Muslims, and we are Muslims, but in words, the Arabs speak of being one with us in religion, but in practice, they marginalise us and build their unexcavated long agenda of an Islamic-Arab nation versus an African nation within Sudan'. ${ }^{329}$

We begin our analysis here with this new rejection by some indigenous Muslim students from Darfur to the ideological model of 'Islamisation and Arabisation' in order to discover whether their rejection has some links with the current violence of ideologies in Sudan. First, their rejection matches with the agenda of the SPLM, which claims that the minority-Muslim-Arabs control the state and use Islam in institutions in order to divide the indigenous African majority and to dictate the terms for ruling and marginalising other regions in the name of the Muslim majority. ${ }^{330}$ It is argued that SPLM's rejection the 'Islamisation and Arabisation' model has motivated the indigenous Fur and Zagahwa ethnic groups in the region of Darfur to launch armed assaults against the government institutions in their territory. de Waal explains that the violence started in February 2003, when a collection of armed men from these two ethnic groups attacked a police station in Jebel Mara. After this assault, the rebels formed themselves into a political and military organisation called the 'Darfur Liberation Front', DLF and chose Abdul Wahid el-Nur from Fur to lead the movement. The SPLM influenced the DLF to change its name into a form that would reflect a wider movement representing the ideological discourse of the 'New Sudan'. ${ }^{331}$ This in turn, is defined as Sudan, where laws for citizens are entirely secular and where all citizens are equally represented in national institutions of state, irrespective of race, gender, ethnic, moral conscience and religion. ${ }^{332}$ Accordingly, the DLF changed its name into Sudan Liberation Movement (SLM) and it military wing, the Sudan Liberation Army (SLA). Many Furs embraced the new organisation, but soon another rebel organisation appeared as well, the Justice and Equality Movement (JEM). Most of it recruits are from Zagahwa. Some people in Sudan including students claim that the JEM has a link with the Islamic political ideology of transforming Sudan into a national Islamic state,

\footnotetext{
${ }^{327}$ Shafaei Adam, a Fur, Omdurman Ahlia University.

${ }^{328}$ Wajdan Muhammad, a Fur, University of Khartoum.

${ }^{329}$ Al-Dom Saeed Muneim, a Fur, University of Khartoum.

${ }^{330}$ Lesch, op. cit., p. 50.

331 de Waal (2005), op. cit., p. 128.

${ }^{332}$ Iyob and Khadiagala, op. cit., p. 137.
} 
where laws are derived from Sharia, but its leaders deny this allegation and explain that their disagreement with the government applies against the ideologies of all preceding governments in Sudan. $^{333}$

This claim is expressed in an anonymous book 'The Black Book: Imbalance of Power and Wealth in Sudan', whose authors identify themselves as 'Seekers of Truth and Justice'. The book argues that the country has constantly been, under the rule of the Arabs from the Northern Sudan. These rulers, whether they are secularists, theocrats, autocratic, aristocratic, democratic Islamists, military dictators or multi-party democratic pluralists, all act in a pattern of promoting injustice and discrimination against the non-Arabs in the state of Sudan. Most of the developmental resources have been concentrated on the development and welfare of the central northern regions around Khartoum, where most of the ruling Arab elite live. ${ }^{334}$ Most of the Northern Muslim Arab students believe that the anonymous Black Book was written and published by the present leaders of the JEM. For example, a Shaiqqiyyia Muslim Arab student from the Northern region argues: 'the violence in Darfur is not genocide; it is ... a normal one. The SPLA trained the SLA in their military zones, during the war between the South and the North. Justice and Equality Movement, JEM is an organisation of Hassan Abdullah Turabi. After Turabi disagreement with President AlBashir in the party, the NCP, his allies that included Khalil Ibrahim, the Head of the JEM rebelled and formed that movement and Turabi supports him morally and politically'.335

In addition, a Ja'aleen Muslim Arab student argues that the JEM: 'is an organisation which supports Turabi's ideologies. This Islamic religious ideologue wants to make Khartoum as a centre of the Islamic Empire for all global radical Muslims'. ${ }^{336}$ According to Petterson, after Turabi ceased power militarily in Sudan, he began to articulate radical methods for building an Islamic state, where Sharia would be the source of legal bills and which would extend also to other parts of Muslim world. He instituted an international centre called the Popular Arab and Islamic Conference in Khartoum. The centre was open to all radical Islamists around the world. After this, he invited Osama Bin Laden, the Head of a claimed Pan Islamic organisation, Al-Qaeda from Pakistan to come to Sudan and establish his organisation there. In response to this invitation, Bin Laden moved to Sudan with his associates which included Hezbollah, the Palestinian Islamic Jihad, the Abu Nidal

\footnotetext{
${ }^{333}$ de Waal (2005), op. cit., p. 128.

${ }^{334}$ Seekers of Truth and Justice, op. cit., pp. 4-6.

${ }^{335}$ Omer Fadol, University of Juba.

${ }^{336}$ Sahlul Muhammad, a Ja'alei, University of Khartoum.
} 
Organisation, al Jama'at al Islamiyya of Egypt, the Islamic Resistance Movement, (HAMAS) of Palestine, and other organisations composed of some radical Muslim movements from Algeria, and Eritrea. $^{337}$

If it is true that the leader of the JEM, Khalil Ibrahim has a link with Turabi's Islamic ideology, then Darfur becomes a centre of a larger ideological discourse that may lead to a further conflict of ideologies between two rebel organisations in Darfur, the SLM and the JEM. The definition of a state in accordance with the Islamic discourse claims that an Islamic state must be religionised, and that Sharia forms the legal constitution around which all the functions of national institutions are to be formed. ${ }^{338}$ This Islamic ideology is contradictory to the secular concept of 'New Sudan' to which Abdul Wahid Mohammad el-Nur the founder and the first leader of the SLM assigned his support. For el-Nur, the Sudan constitution must be exclusively based on laws derived from secular bills. He states "We call for the united federal, liberal secular state" in Sudan. 339

The existence of conflicting ideologies between these two armed organisations has been documented by some scholars from the very beginning of their military operations against the government institutions; however, both have been generally described as insurgents from Darfur based on ethnically divided support. For instance, de Waal says that the JEM draws much of its support and combatants from the Zagahwa subsection of Kobe, while the SLM recruits come from the Tuer, the Bideyat, the Fur as well as the Massaliet. The SLM introduces a secular political orientation to its recruits and the JEM has never promoted a separation of state from religion. Instead, it remains highly receptive to an Islamic ideology of Turabi, the self-proclaimed head of the global Islamists. ${ }^{340}$

It is not easy to confirm the suspicion that the JEM holds ideological perceptions that link it with the Islamists of Turabi; however, inference to the Black Book is necessary in regard to this issue. If the author of this book is a founder of the JEM, then that confirms its connection to the Islamists of Turabi. The anonymous author of the book provides definitive perception to the duties incumbent on Islamic leaders towards the citizens in a state. His definitions rely very much on the derivative

\footnotetext{
${ }^{337}$ Petterson, op. cit., pp. 115-117.

${ }^{338}$ Lunde, Paul (2002). Islam Faith, Culture, History, London: Dorling Kindersley Limited, p. 35.

${ }^{339}$ Shreq al-Awsat (2010 January, 29). "Zaeem Harka Tahreer Al-Sudan Younafi Muthaliba Behaq Taqreer Al-Museer Li Darfur, the Leader of the SLM Denies the Demand for Self-Determination for Darfur” Arabic Newspaper, Shreq AlAawast, Issue No. 11385, p. 2. de Waal (2004), op. cit., p. 56.

${ }^{340}$ Coalition for Darfur (2005 December 2). "Unsimplifying Darfur" http//coalitionfordarfur.blogspot.com/2005//2unsiplifyingdarfur.html, p. 7.
} 
Islamic theories taken from the Holy Quran. For him, the state must observe the five prerequisites defined by one of the key Islamist scholars, Gamal Al-Banna. According to the author, Al-Banna declares that God instructs Islamic leaders to act as caliphs (successors) for Him on the land and to develop it for the prosperity of umma (Islamic nation). Secondly, God also dictates the followers of Islam to guarantee a political atmosphere of religious freedom defined in the Holy Quran according to which 'there is no compulsion on faith'. Third, the essence of a successful Islamic state requires the application of justice as a model in dealing with believers. God instructs believers to be just because justice is the essence of equality among Muslims. And for this, the Prophet Muhammad rejected injustice and strongly prohibited it. Fourth, Shura, (Islamic consultation) is needed on issues of state and the caliph must act, after having sought complete opinions from stakeholders in a state, but his action and decisions should rely on God. Finally, the detracted laws and rules from the Quran must be dictated to people and God "is the sole One to be worshiped in the land" 341 without any other deity beside. ${ }^{342}$

These five prerequisites in an Islamic state unfold the discourses which define the political identity of the author. First, there is a volume of evidence in his textual discourse indicating that the author is seeking an alternative way in establishing an Islamic state; yet, his state remains typically an Islamic one with contradictions. A general overview of the five conditions gives little attention to other definitions of state from other sources ${ }^{343}$ and relies mainly on the Islamic source in building institutions of state. These views leave no space to the people of other faiths in Sudan. For instance, the assertion that urges people to worship only God 'on the land' contradicts with the religious freedom the author claims in the statement 'no compulsion in religion'. ${ }^{344}$ The former statement manifests religious intolerance. ${ }^{345}$ In this sense, a caliph of an Islamic state is a Muslim that represents God 'on the land' and it is incumbent upon him to introduce measures that eradicate religious diversity and impose Islamic way of worship 'Allah' (God) as the only 'One' to be worshipped in a state. These Islamic ideological views suit with an environment, where all citizens are Muslims, but not in a political environment like Sudan. Yet, it violates Article (2) of the African

\footnotetext{
${ }^{341}$ Seekers of Truth and Justice, op. cit., p. 4.

342 Ibid.

${ }^{343}$ Khilnani, Suni "The Development of Civil Society" in Sudipata Kaviraj \& Sunil Khilnani (eds.) (2001). Civil Society History and Possibilities, Cambridge: Cambridge University Press, p. 75.

344 Ibid.

${ }^{345}$ Ankumah, Evelyn A (1996). The African Commission on Human and People's Rights Practice and procedures, Hague: Kluwer, p. 12.
} 
Charter on Human and People's Rights that grants individual African citizens the freedom of religion. ${ }^{346}$

The practical way of worship among the African Muslims is mingled with fetish, which is an assumed source of power; still God is worshipped as the ultimate aim. The author's observation of the indigenous African Muslim guerrilla soldiers of Darfur marks this distinction of the African Islam. Soldiers pray five times a day towards Mecca as Muslims. Yet, they all attire themselves consciously with objects around their necks which they believe carry within them a power to protect a soldier against bullets. For this, a massive collection of talismans offer covers their necks and chests. ${ }^{347}$ This dualistic religious practice expresses diversity within Sudanese Islam, which this research calls the African Islam of God. Also, the name Allah is controversial; it creates conflicting definitions between the African Muslims, Arab Muslims and non-Muslims in Sudan. For instance, in response to the question: is religion important ... A Muslim from Fur ethnic group responds: “All religions, Animism, Christianity and Islam are equally important, but Arab Muslims in power have transformed religion and developed it in the name of Allah into 'fundamentalism' confusing between politics and God. Is Allah really a God or a band of Muslim Arab politicians?"348 In addition, Deng Stephen Garang Angui argues that: "For a Muslim fundamentalist in Sudan, there is no any other genuine name for the Creator of earth and heaven, than the name Allah. I tell them ... I think Allah possibly could be what I know as a Dinka; it is what we the Dinka call Nhialic, but their practice makes it difficult to understand the relationship between Nhialic and Allah. I do not know why they kill the indigenous Muslims of Darfur who have been reciting the name Allah" ${ }^{349}$ Aliir Aquilino Akot Aliir notes: 'religion is very important, but its deviation to fundamentalism makes it ugly in Sudan. In our Church as a Christian interacting with non-Dinka community communicating in English; we call Him God, because the native-English speaking people know Him by that name. So, there is no difference ... you call Him Allah, it leads to God; you call Him Nhialic; it defines the same identity; Allah, but the Muslim fundamentalists here do not comprehend this diverse names of One God, except Allah that is attached with ideological definitions. In practice, the name Allah became ugly among the Dinka, because Jihadists attack them in their villages, while shouting, Allah is Great, Allah is great; Allah is great. Today, among the illiterate Dinka that shout represents death

\footnotetext{
${ }^{346}$ African Charter on Human and Peoples' Rights, adopted June 27, 1981, OAU DOC. CAB/LEG/67/3rev 5, 21.I.L.M. 58(1982), entered into force Oct. 21, 1986.

347 See pictures of soldiers from indigenous SLM and SLA wearing talismans with the author.

348 Anthony Upio Lawrence, a Jur Col, Christian Animist, South Sudan, University of Juba.

${ }^{349}$ Deng Stephen, University of Juba baptised in the Catholic Church and turned to Animism.
} 
and not Nhialic and is known in pejorative name among them as the ruon allahkuber (the year of Allah was Great) that caused inclusive killing of other Sudanese people. It develops to be uglier now in Darfur, where the janjaweed shout the name of Allah, while committing massacre of the indigenous Fur, Massaliet and Zagahwa. ${ }^{350}$

Violence in the name of an abstractive entity known in English as God, Nhialic in Dinka and Allah among the Arabs comes as a result of an attempt to mix politics with these three abstractive names and such political endeavour denotes unstable exploitation of religion in politics of Sudan. Some Muslim students give instances, where Islam has been used in politics leading to the political crisis. The question, "Do you think the exclusion of the South has a link with the past civil wars between the South and North, and if you think so, what about the current violence within the North Sudan as in Darfur, how do you evaluate it?" Some students who answer it claim that 'politicians use religion to divide the people in Sudan. Many use it to reach out to the people's minds to give them power. ${ }^{351}$ Khalil Ibrahim, the rebel leader of the JEM in Darfur was formerly a Minister in the Government of Turabi and President Al-Bashir. He used to speak of the need to protect Muslim religion from its enemies, the Muslim oppositions and the non-Muslims. Now, he is out from power and his views have dramatically changed. He still speaks about Islam, but in a different way than his former political allies in power. Islam has become a source for political debate and not a spiritual quest for God that we see in the Quran and the Sunna of the Messenger Muhammed. ${ }^{352}$ According to Prunier, most people of Sudan describe the leaders of the present Government of Sudan, under Al-Bashir as tujjar ad-din "(merchants of religion)" and they derived this description from their experiences, where these leaders on many occasions manipulated the Islamic religion for their political aims. ${ }^{353}$

Exploitation of Islam in politics has largely failed in Darfur and it has been replaced by racial constructions between the janjaweed and the indigenous population and this has led to another definition of the current war by some students as 'genocide'. Such views have also received support of some human rights organs in the $\mathrm{USA}^{354}$ and the International Criminal Court, ICC. ${ }^{355}$. Some

\footnotetext{
${ }^{350}$ Aliir Aquilino Akot Aliir, a Christian Animist, University of Juba.

${ }^{351}$ Tariq Adel Majid, a Nuba, Nuba Mountains, Omdurman Ahlia University.

352 Amani Hussein Abas, Mahas, Khartoum.

${ }^{353}$ Prunier op. cit., p. 83.

${ }^{354}$ US Official Investigation (2004, July 24). "US Official Investigation Allegation of Genocide in Darfur, Sudan, Secretary Powell to Visit Region, Meet with Sudanese Officials" http://usinfo.stategov/xarchives/display.html=washfile-english=2004\&m=20040624174556ntely0b60.7700464. US Congress (2004, July 23). "U.S. Congress Terms Situation in Darfur “Genocide”,
} 
Muslim Fur, Massaliet and Zagahwa students admit that Islam has once been a unifying factor in fighting against the rebels of the SPLA in the South, Nuba Mountains and Ingessana Hills, but now that political situation has changed. The Government of Sudan has begun to favour racial alternatives in eradicating the rebellion in Darfur. ${ }^{356}$ The new alternative measure for fighting the rebellion drops religion, Islam as a unifying entity in the region of the Muslim Arab of the Northern Sudan. ${ }^{357}$ Alternatively, race is introduced by inculcating into the minds of Muslims with ethnicArab origins in the region of Darfur that the indigenous ethnic African rebels are not good Muslims. In reaction to this inculcation, solidarity and cohesion among the Muslim Arabs in the western Sudan has been ensured under the Arab militia organisation, the janjaweed which seeks out nonArabs in Darfur and kills them. ${ }^{358}$

In the view of the indigenous Muslim students from Darfur the janjaweed have a major role in the current violence within Darfur. The question "Do you think the exclusion of the South has a link with the past civil wars between the South and North, and if you think so, what about the current violence within the North Sudan as in Darfur, how do you evaluate it?" produces students' arguments such as: 'the war in Darfur is the war between the Muslim Arabs, the janjaweed that receive backing from the Arab Muslim government to kill the Muslim indigenous Africans of Darfur. The Muslim Arabs with their janjaweed believe that their Islamic ethnic way of life is the best and become arrogant. ${ }^{359}$ Another states: 'My experience with the janjaweed Muslim Arabs shows me that their faith in Islam is ... mediocre. They are only confident in Arab traditions which they wrongly attach to Islam. For me, this is the reason; they resist other African Muslims to penetrate and teach them about authentic Islam. Islam as a religion urges the universal Muslims to establish equality in institutions, but they see this religious obligation of equality as a threat to their economic and political monopoly. And this is why they always unite to work for the common goals

\footnotetext{
$\mathrm{http} / /$ search.state.gov/search?q=Darfur+genocidefilter=0\&entqr=3\&ud=1\&sort=date $\% 3 \mathrm{AD} \% 3 \mathrm{AL} \% 3 \mathrm{AD} 1 \&$ output=x ml-No-.

${ }^{355}$ International Criminal Court (2008, July 14). Situation in Darfur, the Sudan, Summary of the Case, Prosecutor Application for the Warrant of Arrest under Article 58 against Omar Hassan Ahmed Al Bashir, Maanweg 174, 2516 AB The Hague, Netherlands.

${ }^{356}$ Baldo Salim, a Fur, Omdurman Ahlia University states: "We were Muslims, before the war, but after that Islam was put aside and Arabs versus African Fur emerged in Darfur".

${ }^{357}$ Saleh Muhammad from Zagahwa, University of Upper Nile argues: "The so called Muslim Arab Northern Sudan that included Darfur was a deception. The Arabs are killing us in the territory".

${ }^{358}$ Wadad Muhammad, Omdurman Ahlia University argues: "After the formation of Sudan Liberation Movement in Darfur, the Arabs stirred the Janjaweed and oriented them in their racial meetings to seek and murder the indigenous Fur, Massaliet and Zagahwa of non-Arab ethnic origins at three States of Greater Darfur".

${ }^{359}$ Taleh Ahmed, a Muslim Zagahwa, Darfur.
} 
of ethnic Arab ... and set the religion apart in distribution of power and wealth in the country'. ${ }^{360}$ According to Mans, in the aftermath of the rebellion in Darfur, the slogan formerly used by the Northern Muslims to define the war between the South and the North as violence between the Christians and Animists on one side confronting the Muslims of the North has become an illusion. Religion was smuggled into the present war in Darfur emotionally, but not objectively. Man concludes that currently the government resorts to the recruitment of Muslim Arabs of Darfur the janjaweed as its proxy soldiers to fight Muslims of African ethnic background, the Fur, the Zagahwa, the Massaliet and other non-Arab groups in the region of Darfur. ${ }^{361}$

In the 'Peace Agreement' signed in Abuja, Nigeria in 2006 between the Government of Sudan and one of the rebel factions in Darfur, the SLM led by Minni Minawai Arcua, the term janjaweed was mentioned several times. For example, the agreement urges the Government of Sudan to complete verifiable disarmament and demobilisation of its militia, the janjaweed not beyond the middle of October 2006. The government was also urged to restrict the movements of its other militia, the Popular Defence Forces (PDF) and required to downsize it. A detailed sequencing and phasing schedule was to ensure that the janjaweed and other armed militia have been disarmed, before the rebel forces assemble and prepare for their own disarmament and dis-engagement. ${ }^{362}$ The janjaweed also draw bitter criticism in the question posed to the students: "What is a practice in your religion regarded as sinful, indecent and immoral in which a violator is sentenced, what you think of it and how to deal with believers of other religion(s) violating the same practice in Sudan?" The responses of some students to this question clearly provide the origin of the term janjaweed. Students argue that: "Sins are innumerable in Darfur; janjaweed are devils". Their origin comes from the classical Arabic word: jin means a devil and has nothing to do with jawad which means a horse. In colloquial Arabic of Darfur, jin was distorted and read as jan and juxtaposed with jawad and the two words became one word, janjaweed, to mean two things, a man with a gun on a horse or a devil on the back of a horse. ${ }^{363}$ One student adds that: 'Today, after the war erupted between the government in Khartoum and SLA/M in the region, its vocabulary changed to include any armed nomadic Muslim-Arab tribesmen in Darfur'. ${ }^{364}$ Another student concludes that these armed

\footnotetext{
${ }^{360}$ Sara Muneim, a Fur, University of Juba.

${ }^{361}$ Mans, op. cit., p. 300.

${ }^{362}$ Darfur Peace Agreement 2006, p. 12.

${ }^{363}$ Suber Abdellah, a Muslim Fur, Omdurman Ahlia University.

${ }^{364}$ Sadia Adam, aTama: University of Juba argues "Muslim Arabs (janjaweed) activities conform to the practice of devils, so after the war, Darfurians call them janjaweed".
} 
men constantly unleash discriminating armed assaults on the Fur, the Zagahwa, the Massaliet, Tama and other indigenous African communities in the region. So, in Darfur janjaweed are sinners and immoral Arabs. ${ }^{365}$ According to Prendergast, there are actually two definitions of 'janjaweed'. First, a group of Arab people armed with modern weapons that constantly attack the villagers of the Black-African origin. The victims of the attackers in Darfur call them janjaweed, whether they actually come from the tribal-Arab militia, or the PDF. The United States, however, argues that the state of Sudan recruits its Arab militia, the janjaweed, and that both practice a discriminating war against a defined specific group in the region and therefore, genocide has been committed and is still being committed. ${ }^{366}$

The United States has been much concerned about the violence in Darfur. Different institutions in that country have conducted a series of independent investigations and reached the conclusion that the Government of Sudan has committed genocide against the people of indigenous African ethnic origin in the region of Darfur. Among these institutions is the State Department, where the Ambassador responsible for crimes of war, Pierre-Richard Prosper has cautioned the Members of the Congress to be patient, while his team conducts research to determine the nature of the war in Darfur. Prosper argues that the USA is collecting all information that it can to make a conclusive determination. ${ }^{367}$ After this caution to the Congress, some USA human rights defenders, such as members of the American Bar Association and International Coalition for State Department travelled to Chad, a neighbouring country to Darfur hosting a large number of Darfurian refugees, and started to interview them. The team delivered its report to the Secretary of State Colin Powell. During his testimony over this issue before the Senate Foreign Relations Committee on 9 September 2004, the Secretary defined the practice of the Government of Sudan and janjaweed as amounting to a consistent and widespread pattern of atrocities of killings, rapes and burning of the indigenous villages. Those who committed these atrocities are the janjaweed and the government forces against non-Arab villagers. The report states "We conclude that genocide has been

\footnotetext{
${ }^{365}$ Muawad Al-Sheikh a Massaliet, University of Khartoum.

${ }^{366}$ Prendergast, John (2005, February). Resolving the Three Headed War from Hell in Southern Sudan, Northern Uganda and Darfur, African Program Occasional Paper Series, Woodrow Wilson International Center for Scholars, No. 3 , p. 5.

${ }^{367}$ US Official Investigation (2004, July 24). "US Official Investigation Allegation of Genocide in Darfur, Sudan, Secretary Powell to Visit Region, Meet with Sudanese Officials" http://usinfo.stategov/xarchives/display.html=washfile-english=2004\&m=20040624174556ntely0b60.7700464.
} 
committed in Darfur and that the government of Sudan with its janjaweed bear responsibility and genocide may still be occurring", 368

Powell's assertion that 'genocide may still be occurring' conforms to the opinions of the majority of students from Darfur who responded to the questionnaires. For example, a Zagahwa student at the University of Khartoum argues: "In my evaluation of this war in Darfur, it is genocide. Arab militias attack and kill a significant number of civilians, because of their being not Arabs, so how do we define such systematic practice?" ${ }^{369}$ In contrast, the Arab Muslim students provide a different version. There is not a single Arab Muslim student who defines the practice of war between the indigenous ethnic Darfurians and the Government of Sudan as 'genocide'. Just one instance, a Kababish Arab student of Northern Kordofan studying at Omdurman Ahlia University argues: "The government of ... President Omer Hassan Ahmed Al-Bashir has no project of killing non-Arabs in Darfur. I saw on different international television channels a massive destruction which must be the work of janjaweed; perhaps this militia determines the identities that they want to kill in Darfur, but not our President Al-Bashir". ${ }^{370}$ Also, the indigenous ethnic students from Darfur do not believe that the international community is making a humanitarian move to defend them from 'genocide'. 371 One student argues: "When you deny a person existence, because of his race, then that is ... genocide. The Arab militias of janjaweed hunt for the specific race in our villages rape their women and kill them, yet the world watches the genocide. When it was committed against the Muslims in Serbia, Europe was outspoken, and when its atrocities are beyond compare with those committed in Serbia, the institutions of the Europeans Union option talks and talks without military measures to stop genocide of a big number of our people dying every day in Darfur". ${ }^{372}$

\subsubsection{Humanitarian crisis and controversy over genocide}

The question in the questionnaires "Do you think the exclusion of the South has a link with the past civil wars between the South and the North, and if you think so, what about the current violence

\footnotetext{
${ }^{368}$ Powel Reports (2004, September 9). "Powell Reports Sudan Responsible for Genocide in Darfur" http://usinfo.state.gov/xarchives/displayhtml?p=ashfileenglish \&m=2004\&m=mseptember \&x=2004090911155958JTgni lwoDo50.

${ }^{369}$ Zubida Ahmed, University of Khartoum.

${ }^{370}$ Muhammad Sadiq Adam, University of Juba.

${ }^{371}$ Wathiq Ahmed, a Fur, University of Juba "Genocide has been committed against our people and the world does not react. "International Community... refuses to stop the killing of our people. "Why is only the USA concern in protecting us; where is the International Community? The International Community is silent in the face of genocide in Darfur. Britain annexed Darfur to the Muslim Arab area and now they kill us and they do not move to rescue us".

${ }^{372}$ Ali Abu Nahala, a Fur, University of Khartoum.
} 
within the North as in Darfur, how do you evaluate it? The responses to this question causes the majority of students coming from Darfur to claim that they had mothers, sisters, brothers, maternal and paternal uncles and many other relatives who have lost their lives due to "genocide". ${ }^{373}$ The claim goes as: 'I came to study at this university and left my mother and my brother in the town of Bindisi in Darfur. Today, they are dead, because they are not Arabs and that is what I evaluate as genocide. ${ }^{374}$ Another stated: "For me, the classification of who is to be killed, because of being a non-Arab is what the people of Darfur face ... today. Killing them, because of who they are, is organised in Khartoum and it is continuing and that is genocide". ${ }^{375}$ Some students blame China's role in blocking international recognition for acknowledging that genocide has occurred in Darfur and they praise the role of the USA for having stood against the Government of Sudan. They present their arguments as following: "The ... government instructs janjaweed to kill every Fur, Zagahwa and Massaliet in villages of Darfur and the UN panel of investigation covers up these facts. The UN is under the control of some egoistic countries such as China which cares less about humanity and pursues all interest in Sudan". ${ }^{376}$ One of them asks a question; "What evaluation could one offer in describing this war more than genocide organises in Khartoum and no one report says this, than the USA and cannot act, because the Security Council of the UN is an organ of China and the Arabs". ${ }^{377}$ One Muslim from Fur concludes that: 'the people of my ethnic group, the Fur are hunted ... in the area as if they were wild beasts simply, because they are Fur; if the USA were not embedded in its war in Iraq we would have not continued to die in Darfur. The USA understands humanity and China understands economic advantage'. 378

The UN definition of genocide forbids deliberately inflicting on any the group conditions of life calculated to bring about physical destruction in whole or in part. ${ }^{379}$ In reaction to the arrest warrant issued by the Prosecutor of the International Criminal Court (ICC), Luis Moreno Ocampo for the President of Sudan, Al-Bashir for the alleged genocide and war crimes committed against the Fur, the Zagahwa and the Massaliet ethnic groups of Darfur, the Head of the government Humanitarian

\footnotetext{
${ }^{373}$ Ali Anur, University of Khartoum: "I have lost my parents, because of being Fur, so I believe it was genocide. My sister was murdered with her four children, because they were not Muslim Arabs, and this was genocide.

${ }^{374}$ Mahdi Adam, University of Khartoum.

375 Anonymous, Muslim, a Zagahwa, University of Juba.

${ }^{376}$ Mimi al-Tom, a Massaliet, Darfur, Omdurman Ahlia University.

${ }^{377}$ UN Commission of Human Rights Report, 2006.

${ }^{378}$ Shima Ahmed, University of Bahr el Ghazal.

${ }^{379}$ Convention on the Prevention and Punishment of the Crime of Genocide adopted by the Resolution 260 (III) A of the U.N. General Assembly on 9 December 1948.
} 
Affairs Commission (HAC), Hassabo Mohammad Rahman accused thirteen international NonGovernmental Organisations (NGOs) in service delivery to the IDPs in Darfur of espionage and conspiracy against the President. He argued that the NGOs collaborated with the ICC in giving information which targeted the President. On 5 March 2009, a decree of expulsion of thirteen NGOs was issued and their offices with their available assets were confiscated and their bank accounts were closed. The licenses of other three national NGOs which operated in Darfur were revoked. ${ }^{380}$

A few days after the expulsion, some international NGOs warned that the expulsion jeopardizes 1.1 million people to starvation, 1.5 million without healthcare services and at least one million without access to water in Darfur. ${ }^{381}$ This specific circumstance of humanitarian crisis prompted the UN Secretary General Ban Ki-moon to raise a general alarm urging the Government of Sudan (GoS) to reverse its decision of expulsion. Ban stated: "I have made my sincere appeal and also urge the many Arab and African leaders to influence ... President Al-Bashir to reverse the decision of expelling humanitarian workers". ${ }^{382}$ Under this alarming condition, the UN Humanitarian Coordinator John Holmes visited Khartoum and held several sessions of discussions with the GoS to reverse its decision. Reporting to the UN Security Council on 11 June 2009, Holmes stated “... the gap left after the March expulsion of the international organisations was particularly serious in areas such as education, reproductive health and livelihood assistance and the overall humanitarian situation". ${ }^{383}$ Holmes concludes that the GoS assured him that it would readmit some expelled NGOs, under the condition of introducing some changes to their logos. ${ }^{384}$ In contrast, visiting Zamzam one of the IDPs camps in Darfur, the US Presidential Envoy Scot Gration confirmed that 70,000 IDPs in the Zamzam were in extreme shortage of food, water and health services. He argued: "I don't think that the prospects for returning the thirteen NGOs as a group of thirteen are very strong or very high". 385 Gration continued to argue that such humanitarian circumstances need a humanitarian agency to immediately come up with creative ways, and stated: "I say immediately,

\footnotetext{
380 Sudan Expels Agencies (2009, March 12). "Sudan Expels Aid Agencies after the ICC Warrant" www.reliefweb.int/rw/rwb.../CJAL-7PTQSF?...-

${ }^{381}$ Sudan (2009 March, 9). "Sudan: NGOs Expulsion to Hit Darfur Displaced", www.irinnews.org/Report.aspx?Reported=83370.

${ }^{382}$ Ban Hopes (2009 April, 7). "Ban Hopes Sudan Reverses Its Decision to Expels International NGOGs" http//www. unmultimedia.org/radio/english/detail/72606.html.

${ }^{383}$ Sudan (2009, June 11). "Sudan: Key Recent Development", http/www.securitycouncilreport.org/atf/cf/\%7B65BFCF9-6D27-4E9C-8CD3CF6E4FF9FF9\%7D/July\%2009\%20FForecast.pdf.

384 Ibid.

${ }^{385}$ Gration on Sudan (2009, June 7). "Gration on Sudan Our approach Is very Comprehensive", http://www.enoughproject.org/blogs/gration-sudanour-approach very comprehensive
} 
I mean in the next weeks to be able to compensate the critical situation by bringing in resources and the determination of taking steps to expand the capabilities of the existing NGOs". 386

In fact, Gration's language has constructed two new phenomena of relationships between the GoS and the NGOs. First, it has emboldened Khartoum with impunity to deny the access to any humanitarian organisation which does not fall within the definition of its political regulations designed by HAC in service delivery to the IDPs. Some few international NGOs left on the ground after the expulsion operate now, under an environment of anxiety and dilemmas between the defined strategies of the HAC and their defined mandates of their missions as non-political, but humanitarian agencies. For instance, in Nyala city one director of an international organisation complains to the author that its agency has seriously deviated from its ethical mandate in Darfur, because of the HAC. ${ }^{387}$ Second, Gration's language has stalled the appealing efforts of the Secretary General of the UN to press the GOS to reverse its decision of expulsion. Addressing the audience on 23 July 2009, at a rally in el-Fasher, capital city of the Northern State of Darfur, President Al-Bashir responded to the UN that his government would expel more agencies of the NGOs, including diplomats and peacekeepers that would not comply with the directives of the GoS. 388

Indicators on the ground show that the expulsion has created a new situation of move of a search for security and shelter for the IDPS. For the last nine months, since the expulsion of the aid agencies, the humanitarian situation has been appalling. During September the Sudan Armed Forces (SAF) in combination with the janjaweed launched the deadly attacks to the areas around Korma town, northwest of el-Fasher as well as Jebel Marra in the Southern Darfur State of Nyala. ${ }^{389}$ The presence of this researcher in the field as an eyewitness, during the last visit to Sudan in early July 2009, indicates a convergent line with the other NGOs claim that the expulsion has triggered a catastrophic humanitarian profile to the IDPs of Darfur. The IDPs at the extensive locations of camps are in grave risk of starvation, endemic diseases, lack of oil to pump water from deep holes and leave alone the right of the IDPs children to education. Currently, the situation is disastrous; the IDPs are subjected to a dilemma: hunger in the camps and high profile of insecurity at their villages.

\footnotetext{
${ }^{386}$ Associated Press (2009 April 4). "US Special Envoy Proposes New NGOS for Darfur”, Khartoum, 1.

387 Anonymous NGO Official in Nyala Discussed with the Author on 4 July 2009.

388 Sudan (2009, July 24). "Sudan: NGOs Expulsion to Hit Darfur Displaced" http://www.irinnews.org/report.aspx?Reportid=83370.

389 Ray Aam (2009 September 20). "Maraka thid al-kawarej fil Darfur War against the Insurgents in Darfur", Arabic Newspaper, Ray Aam, Issue No. 1892, p. 1.
} 
Some who attempted to return to their villages were faced by the janjaweed attackers. Some crossed to Raja, a city that borders Darfur at the Western Bahr el-Ghazal State of South Sudan. In Raja they reside in appalling conditions in their squatter areas of Khor-Madia and other squatters are in the north west of the city. The researcher had witnessed those with meningitis and others who clutched their abdomen with complaints of unknown ailments and those with severe diarrhoea. Pregnant women remain without access to health service. There are no sources of food supply, no schools for children, shelters and clothes. In towns of Aweil capital city of the Northern Bahr el-Ghazal State and Wau capital city of the Western Bahr el-Ghazal State have been receiving a huge number of desperate IDPs from Darfur. The condition of women and children of IDPs from Darfur in the camps of these two towns is dramatic and tragic. The rapid increase of IDPs from Darfur has aggravated the humanitarian situation of the first IDPs at Gondolo camp in the city of Wau. The camp is in grave need of food items with clear total absence of shelter and hygiene.

The present search of the indigenous population of Darfur for a refuge and security for their rights to life in the South disqualifies the report of the two formers United Nations/African Union Mission in Darfur (UNAMID). In August 2009, Commander Martin Agwai, during the end of his tenure issued a statement on the British Broadcast Corporation (BBC) claiming that: As of today, I would not say there is a war going on in Darfur". ${ }^{390}$ In addition, Rodolphe Adada Special Representative UNMID repeated Martin's statement, when departing at the end of his service contract. Adada claimed that: "There is no more fighting proper on the ground". Right now there is no high intensity conflict in Darfur ... Call it what you will but this is what is happening in Darfur---a lot of banditry, carjacking, attacks on houses". 391

The statements of these two former leaders of the UNAMID contradict the joint report of the United Nations High Commissioner for Human Rights (UNHCR) and the Department of Peacekeeping Operations of the UNAMID, during the tenures of those two men. The report states: "Consistent information gathered by UNAMID and Human Rights Offices (HROs) indicated that Military attacks" against the villages of Sirba, Silea and Abu Suruj at Western Darfur "violated the principle of distinction ... to distinguish between civilian objects and militarily objectives. As a result, at least 115 persons were killed, including elderly people, women, children and more than 30,000 individuals forcibly displaced to other locations ... NGO clinics and offices, community

\footnotetext{
${ }^{390}$ Martin Agwai (2009, August 27). “War in Sudan's Darfur Is over”, news.bbc.co.uk/17hi7world/Africa/8266314stm.

${ }^{391}$ Rodolphe Adada (2009, October 11). "Rodolphe Adada Address to the African Synod", www. zenith.org/article27153?1english.
} 
centers, water structures, schools, food storages, milling machines and shops were systematically pillaged, vandalized and/or set ablaze. Livestock was also looted". 392 The report concludes that the coordinated attacks of the Sudan Armed Forces and militia against the areas of the indigenous people have increased the number of the IDPs, where more than 450,000 were newly displaced. During 2008 alone there were 317,000 IDPs. ${ }^{393}$

The humanitarian situation in Darfur continues to escalate and there is no progress of peace negotiation as the SLM leader El-Nur places pre-conditions for negotiation with the Government of Sudan. He states: "No negotiation without security on the ground; the government must first stop genocide, rape, disarmament of janjaweed militia, expulsion of the foreign identities being resettled in the lands of Darfur". 394

\subsubsection{Beja Congress}

Beja is a nomadic ethnic group that lives in an extensive region that borders Ethiopia and Eritrea at the eastern part of Sudan along the Red Sea. ${ }^{395}$ Most of the interviewed Muslim Beja students offer five political grievances against the central authority. Their complaints date back to the historical foundation of the independent state of Sudan and to different political experiences they have faced at different phases during the process of constructing a Sudanese citizen state. These political grievances appear from the answers of the question which asks "How did the east, west, far north and centre become the Northern Sudan Region in exclusion of the South and what does the name of your region and Sudan mean in your native language and do you experience any difficulty in articulating it?" First of these complaints is the issue of the territorial national identity. Some of the students claim that the Beja were originally an independent and distinct cultural group, under their own territory known as Hadarieba. ${ }^{396}$ This Hadarieba was attached to be a part of the current

\footnotetext{
${ }^{392}$ Ninth Periodic Report (2008, March 20). "Ninth Periodic Report of the United Nations High Commissioner for Human Rights on the Situation of Human Rights in the Sudan", http//www.ohchr.org/documents/Press/WestDarfurreport2003.pdf. ${ }^{393}$ Ibid.

${ }^{394}$ Shreq al-Awsat (2010, January 29). "Zaeem Harka Tahreer Al-Sudan Younafi Muthaliba Behaq Taqreer Al-Museer Li Darfur, the Leader of the SLM Denies the Demand for Self-Determination for Darfur", Shreq Al-Aawast, Arabic Newspaper Issue No. 11385, p. 2.

${ }^{395}$ Holt and Daly, op. cit., p. 8.

${ }^{396}$ Osman Wasilla, University of Khartoum: "We were independent people nation, the Hadarieba state, but we falsely became a part of wrong Sudan inequality. "We know that, there is no equality, so we must revive our territory, the Hadarieba".
} 
territorial nation-state of Sudan without consideration of cultural differences between the Beja and the Arabs. ${ }^{397}$

The students claim that it was the Turco-Egyptian regime that forced the national borders of the current Sudan forcing the Hadarieba to join Muslim Arabs. The students argue that: 'our norms and values as Beja Muslims are quite often different ... from Arab Muslims. These cultural differences were ignored and the Beja became one with the Arabs in the territorial state of Sudan". ${ }^{398}$ Another continues: 'The Arabs were ... immigrants with their cultures and we were here on this ground as its owners with the Nilotics residing at the centre of Sudan and now in South Sudan". ${ }^{399}$ One student concludes that: “... it would have been logical to attach the primary natives of the land together, but South Sudan was set apart from us and Arabs want to assimilate us; we shall seek for our destiny and establish our territorial state of Hadarieba." 400

After the independence of Sudan, the Beja developed political consciousness of their specific and unique identity. In 1957, Taha Osman Bileya with other intellectuals from the Beja formed the political ethnic organisation, 'Beja Congress'. The aims of the organisation were many; however, they included maintenance of Beja cultural identity, eradication of economic marginalisation of their region and an equal participation in power sharing. Studies by Holt and Daly maintain that the Beja is a conservative ethnic group and this is specially the case with its sub-ethnic group, the Hadendawa which has its own customary norms. The Beja reject association with the Arabs; they always define themselves in political and social contacts as Beja. They dismiss efforts of linking them with Arabs. Its political wing, the Beja Congress urges the central government to open up opportunities in power and wealth distribution that include their region. ${ }^{401}$

\subsubsection{Marginalisation and assimilation of the Beja}

Beja students also complain about their economic and political marginalisation. In their opinions, different political constructors of national institutions in Sudan marginalise them extensively in

\footnotetext{
${ }^{397}$ Khalid Teseer: University of Juba states "We are Beja; we have our different tongues, the others in power are mainly Arabs with Arab language, so we are different people".

${ }^{398}$ Abede Omer, University of Khartoum: "This political inequality was caused by the Turks and Egyptian who forcedly annexed us to the Arabs of the Northern Sudan".

${ }^{399}$ Saha Muneir, University of Juba: "The Arabs came with their culture as immigrants and found us with indigenous Nilotics of the current South Sudan".

${ }^{400}$ Mubarek Osman, University of Khartoum, a Beja. Halima Mohammad: "Our conflicts with Arabs are based on an attempt to assimilate us to Arabism. We say that we have been here with the Nilotics and would be better for us to assimilate them to Africanism".

${ }^{401}$ Holt and Daly, op. cit., p. 2.
} 
terms of distribution of power and wealth in the territory which they call their 'own land'. This came up from the answers to the research question, "How do you want national identity of these regions to be defined in a national constitution of Sudan and under what system best suits Sudan and why you think so?"Answering this question, one of the Beja students says that: "Democracy with its values of freedom and equality within all institutions of Sudan is the best, but Sudan has never experienced such a system in its political institutions, under the power of the Arabs in Sudan." ${ }^{402}$ One concludes that: "The Arabs marginalise our region in developmental projects and whenever, we express our grievances, then they use power and kill us." 403

The students' claims of the absence of democratic values and economic marginalisation of the Arabs to the region of Beja are necessary for our analysis. The reason is to gain explicit understanding of the claimed 'democratic values'. According to Haralambos and Heald, in a democratic society, laws are not always "an expression of value consensus but a reflection of ruling class ideology. They serve to legitimate the use of ruling class power. Thus, a general commitment to laws by members of society as a whole is an aspect of false class consciousness since, in practice; laws benefit only a ruling minority." ${ }^{404}$ A body of a legislature in a democratic society that enacts constitutional laws in a national parliament without a consensus of the other existing political parties represents an oppressive democracy, since those laws are not necessarily advantageous for the inclusive territorial citizens; instead they privilege a specific body of a class, which may be ethnic or religious group. This phenomenon transforms democracy to become an unattractive political strategy in political forums for the benefit of an identical class. It characterises it to become an ambiguous term in our minds, and therefore, what is really democracy? Traditionally, the term democracy originated from the Greek word, kratos refers to power or rule. Thus, democracy stands for 'rule by the demos' and the term demos meaning the people. ${ }^{405}$ This definition creates a conflict of the democratic theory. Held explains that theoretically, the term democracy has created a conflict, whether it refers to popular power "a form of politics in which citizens ... engaged in self-government and self-regulation) or an aid to decision-making (a means of conferring authority on those periodically voted into office)". Held concludes that these conflicting definitions have resulted three models of democracy. First, participatory democracy, which is a system of decision-making that directly involves citizens about the issue of public concern; second, there is a liberal or representative democracy, which is a system of rule based on the elected

\footnotetext{
${ }^{402}$ Ahmed Ghazi, University of Khartoum.

${ }^{403}$ Mohmad Musa Abdullah, a Beja, University of Khartoum.

${ }^{404}$ Haralambos, Michael and Heald, R M (1981). Sociology: Themes and Perspectives, Oxford. Collins Educational, p. 442.

${ }^{405}$ Heywood, Andrew (2003). Political Ideologies an Introduction (3rd ed.), Hampshire: Palgrave Macmillan, p. 43.
} 
representatives that represent the interest and views of citizens and uphold the 'rule of law'. Finally, there is a democracy based on one-party system, which regulates laws for citizens. 406

In the view of this researcher, representative democracy with its modern version constructed by Abraham Lincoln, former President of the USA in his Gettysburg address of 1863, where he defines democracy as a 'government of the people by the people and for the people ${ }^{407}$ best suits the current diverse ethnic and religious institutions of Sudan. The government in power, however, does not identify these democratic virtuous values for its inclusive people. For this reason, the Beja people complain and in reaction, the government 'imagined' them as 'enemies'. According to de Waal and Abdel Salam, in early 1993 the Beja Congress took up arms against the central government in Khartoum. In reaction to their demands, the government defined them as "enemies of Islam" and attacked their villages. de Waal and Abdel Salam conclude that, in a press conference in Kampala in February 1999, some of the Beja leaders, such as Sheikh Omer Al-Tahir raised up a partly burned text of the Quran by the government armed forces to their area of Gedamayeb and presented a question while holding up the text: "How can a Muslim government do this?" ${ }^{408}$ In addition, imam (pious Islamic cleric) Adam Tutu Atrun commented on the scene of Holy Quran as: "Islam does not allow Muslims to do this". ${ }^{409}$ After this rebellion, the leader of the organisation, Musa Mohamed Ahmed defined the political objectives of the organisation that it took arms to rectify discrimination of Arabs in sharing power and wealth. ${ }^{410}$ Antalöv and Ngo observe that in an authentic democratic environment of political pluralism, "the ballot ruled, not the bullet". ${ }^{411}$

The reversible political structure of Sudan from 'democratic values' of freedom to expression and peaceful demonstrations have a negative repercussion among the citizens of Sudan, where the 'ballot' system is absent and the 'bullet' rule of system is in operation. The Beja went for political demonstrations urging the Government of Sudan to introduce projects of development in their region in January 2005. Their demonstrations led to a violent reaction from the government. Amnesty International reports that some Beja staged a peaceful demonstration on 26 January 2005 in the city of Port Sudan demanding equal and fair share of the wealth and power in the region. On

\footnotetext{
${ }^{406}$ Held, David (1995). Democracy and the Global Order from the Modern State to Cosmopolitan Governance, Oxford: Polity Press, p. 5.

${ }^{407}$ Cited from Heywood, Andrew (2003). Political Ideologies an Introduction (3rd ed.), Hampshire: Palgrave Macmillan, p. 43.

408 de Waal, Alex and A H Abdel Salam "Islamism, State Power and Jihad in Sudan” in Alex de Waal (ed.) (2004). Islamism and Its Enemies in the Horn of Africa, Addis Ababa: Shama House, p. 73.

${ }^{409}$ Ibid.

410 Speech of Musa Mohamed Ahmed in Asmara, Eritrea on 28 January 2005.

${ }^{411}$ Antalöv, Hans and Ngo, Tak-Wing (eds.) (2000). The Cultural Construction of Politics in Asia, Surrey: Curzon, pp. 19-21.
} 
Saturday, 29 January 2005, the police and security forces shot twenty demonstrators dead. Amnesty concluded that the security forces seemed to have acted discriminatively as many of those killed or wounded were children uninvolved in the demonstration. ${ }^{412}$

Some Beja students present bitter arguments such as: 'colonialism was cautious of the democratic values, but it handed power to the barbarian Arab elite of capitalism in the centre of the country, Khartoum.' ${ }^{413}$ Another one said 'these elite gripped power and commenced to marginalise the marginal areas at the east, the west, and the south. ${ }^{414}$ One concludes: 'the Arabs directed the national wealth of state on the developmental projects around their regions'. ${ }^{415}$

Marginalisation on wealth and power sharing prompted the Beja to form the ethnic party, Beja Congress, since 1958. ${ }^{416}$ Experience of political marginalisation by certain groups in Sudan motivates them to construct and maintain ideological associations to assert their identity and political interests. Lesch observes, since the independence of Sudan, two Muslim Arab sectarian organisations, the Khatimyyia with their party the DUP and the Ansar with their party the Umma dominated Sudan. During the election of 1958 for the National Assembly, political representatives from the South, the Beja, the Nuba and the Fur adopted a unified stance as the marginalised people and sought a decentralised governance system that would allow them to participate in the decisionmaking. Their demands were rejected by the Umma and DUP in power and they could not do anything due to their "smaller numbers and limited representation in the parliament". 417

The third complaint is against attempts by the elite to remove the structures of diversity and substitute it with homogeneity based on the inter-independence of Arab identity and Islam. ${ }^{418}$ Some students argue that: "Sudanese thought that after independence, we would have a suitable system which embraces the culture of all ethnic and religious groups, so that peace is ... maintained, unfortunately power was inherited to the Jellaba. These Arab elite started to pursue the policy of getting rid of the existing ethnic and religious diversity in favour of un-dividable Arab and Islamic

\footnotetext{
412 Amnesty International (2005, January 31). "Sudan: Those Responsible for Indiscriminate Port Sudan Killings must Be Brought to Justice”, Amnesty International Press Release, AI Index: AFR54/014/2005, News Service No: 024.

${ }^{413}$ Bitul Salah, University of Upper Nile.

${ }^{414}$ Gada Muhammed, University of Bahr el-Ghazal.

${ }^{415}$ Gasim Rejeb, University of Khartoum.

${ }^{416}$ Sarah Mirghani, University of Khartoum.

${ }^{417}$ Lesch, op. cit., p. 37.

${ }^{418}$ Zaki Ali, University of Khartoum asks: "Why do you want to change me from being a Muslim Beja to a Muslim Arab?"
} 
identity versus indigenous people of Sudan." ${ }^{419}$ another states: "The Beja are very strong nation to be assimilated into Arabism .... It is only ... we are Muslims, yet, with our unique way of life it is difficult for any regime to assimilate us. One Beja student concludes: 'We have resisted all the historical endeavours of Arabs, Romans, Pharaohs and Turks to assimilate us. Now, political efforts of the present Arabs in power to Arabise and Islamise the state have caused racial discrimination and segregation within the social and political domains of the country'. ${ }^{420}$ One of the students offers democratic pluralism as an alternative system for the country claiming that it allows political space for negotiating political differences that may lead to the eradication of discrimination, but that the 'autocratic Islamic' system of Al Ingaz (Salvation) Revolution of the President Al-Bashir assembles Muslim Arabs and raises a threatening slogan that says: 'whatever taken in force must be restored back in the same way'. So, for me, Islamic autocratic system of Islamic fundamentalism understands only the language of weapons and not negotiation." 421

The Government of the President Al-Bashir is an extremely radicalised Islamic government that gives no opportunity for political negotiation to any political body that would hold enough power to threaten its existence. For instance, addressing the gathering at the Republican Field in Kassala town for the nineteenth anniversary of the militia, the PDF, President Al-Bashir stated: "We do not fear anyone, except God; and we do not bow before any one; nor do we praise anyone except Him." 422

The radical threatening language used by President Al-Bashir has changed after the ICC Prosecutor, Luis Moreno Ocampo applied a warrant to arrest him for the alleged genocide committed against the Fur, the Zagahwa and the Massaliet ethnic groups of Darfur. ${ }^{423}$ Al-Bashir has adopted more patience, interest and tolerance towards the opinions of other political parties in Sudan. ${ }^{424}$ Nine days after the news from The Hague concerning the arrest warrant, Al-Bashir visited Darfur on 23 July 2008 and spoke of the necessity to reach a consensus over the issue of

\footnotetext{
${ }^{419}$ Hadi Abdel Karim, Omdurman Ahlia University.

${ }^{420}$ Bakri Saleh, Omdurman Ahlia University.

${ }^{421}$ Mohammed Abdu, University of Juba.

${ }^{422}$ Ray Al-am (2008, July 17). “Al-Bashir: Jihaat Tahawel Al-Fitina lel-Istella aala Arathei Al-Hausa, Al-Bashir: Some Strive to Create Social Disorder to Occupy the lands of Hausa”, Ray Al-am Arabic Newspaper, Issue 1081, p. 1.

${ }^{423}$ International Criminal Court (2008, July 14). Situation in Darfur, the Sudan, Summary of the Case, Prosecutor Application for the Arrest Warrant under Article 58 against Omar Hassan Ahmed Al Bashir, Maanweg 174, 2516 AB, the Hague, Netherlands .

${ }^{424}$ Sudani (2008, July 25). "ICC, al Natham al-Jadid lel-AlBashir, ICC, a New Weapon to the Regime of Al-Bashir", Arabic Newspaper, Sudani, Issue No. 951. Before the announcement of the arrest warrant by the Prosecutor of the ICC, Al-Bashir invited all political parties in the guest house and paid attention to their views, p. 1.
} 
peace, instead of violence between all peoples of Darfur. He accepted some demands of the rebels, such as the refund of those indigenous people whose possessions have been destroyed and looted by the janjaweed and government forces. He also asserted to negotiate with the JEM, which he had ruled out of any negotiations. ${ }^{425}$

\subsubsection{Prejudice against the Beja}

The fourth complaint by the Beja students is discrimination and prejudice by the Arabs in power against them. They argue that ethical teaching of Islam prevents discrimination, and so religion, Islam is free from this political discrimination in Sudan. Islam as a religion is not the reason for political instability. Politicians misuse Islam for their political benefit and discriminate against Muslims who are not Arabs. The result of that discrimination has brought the prevailing disunity, hatred and war between the indigenous Muslim Beja against Muslim Arabs within the Northern Sudan Region. ${ }^{426}$ Under discrimination, one of them argues: "We must know that, war against the Beja Muslims reminds us ... that it is not the first time in the Islamic history for some Arabs to pursue discrimination of non-Arab Muslims from the divine message of Islam for all ... nations. Muslim Arabs in Sudan reject deliberately the obligatory equality articulated in Islamic religion to all Muslims. They practice contrary norms of Islam, especially racism against converts of non-Arab origins to Islam, and not because they do not know the Quran; they know it, but lust of power and greedy for wealth blind them". ${ }^{427}$ Sudan's Presidential Advisor, Mansour Khalid argues that Arab racism in Islamic Sudan is traditionally inherent in the original racial discrimination towards faithful non-Arab Muslims. The Arabs in Sudan fail to comprehend the Prophet Muhammed's definition of an Arab. The Prophet warned the Arabs that: "you people, God is One and One Father, Arab is not Arab from an Arab father and mother, but the tongue, so whoever that speaks Arabic, then he is an Arab." 428

\footnotetext{
${ }^{425}$ Sudani (2008, July 24). “Al-Bashir fil Darfur”, “Al-Bashir in Darfur”, Arabic Newspaper, Al-Sudani, Issue No. 983 , pp. 1-2.

${ }^{26}$ Naima Mahjoub, Omdurman Ahlia University: “Application of Islam as a political entity, where the Beja suffer discrimination brings dis-integration among the Umma of the Northern Muslims. "If Islam was not used in this very discriminating way that I see here in politics, we would have been well off in the Northern Sudan". Rehab Jafer, University of Khartoum: "Discrimination of Arab Muslims to other non-Arab groups in the North of Sudan has caused opposition; instead of love, it has caused hatred, no reconciliation, rebellion, so we remain in a state of disorganised unity".

${ }^{427}$ Amira Munem, University of Khartoum.

${ }^{428}$ Khalid, Mansur (2007, April 6). "Al.Onsoria in Islam", "Racism in Islam”, Electronic Arabic Newspaper Sudanile, p. 4. www.sudan.net.
} 
Some Beja students claim that they usually experience racial prejudice within the institutions of Sudan, but this prejudice was inherited by the Arabs from the colonial British policy that categorised the Beja, as "aggressive and uncultured." ${ }^{429}$ According to one Beja; the Arabs in control of power in Khartoum follow the same derogatory prejudice that categorise "us as uncultured ethnic group." ${ }^{430}$ Many of Beja students present more arguments that Islam is an independent religion that unifies worshippers in faith, but has not successfully dropped racism within Islam. ${ }^{431}$ Another one states: "It is true, we are Muslims, but there is a difference between religion and race. Islam unites us as the people of one faith, but it is difficult for one like me to identify myself as an Arab, because I am a Muslim." ${ }^{432}$ One Beja concludes: "If a Beja person denounces Beja cultural identity, it would equally reflect a cultural suicide of eradicating cultural distinction". ${ }^{433}$ Holt and Daly observe that the five sub-ethnic divisions of the Beja express diversity in terms of cultural practices. The Hadendawa who reside at Tukar in the region of Gash have been categorised as the most aggressive and "uncultured savages". 434

This form of derogatory stratification of ethnic cultures into 'uncultured' and 'cultured' originated from the colonial British officials in Sudan and has entered into the social institutions of the Islamic North; however, not all British Administrators were involved in such categorisation. According to Deng, British Administrators in Sudan were divided over their observations of the Hadendawa. Some described them as uncultured, nomadic and savage and others viewed them differently. For instance, the Former British Governor T R H Owen expressed his great love towards Sudan and in particularly the culture of the Hadendawa. ${ }^{435}$

Applying social theory in analysing the divisive categories of British Administrators on the cultural identity of the Hadendawa, we must conclude that some of the administrators were affected by 'sociological imagination', during their interactions with the Hadendawa. In the view of Mills, when a person is exposed to an environment of alien cultures, social imagination helps to imagine the other group as distinct and its behaviour does not necessarily match with the privately

\footnotetext{
${ }^{429}$ Diana Saber, University of Khartoum.

${ }^{430}$ Mahmoud Al-Agebi, University of Khartoum.

${ }^{431}$ Mariam Omer, University of Khartoum.

${ }^{432}$ El-Kahir Usman, University of Juba.

${ }^{433}$ Salim Faisal, University of Juba: "Our Governor of the Red Sea state is a Beja, but he does not say it, nor does he behave as a Beja. In my opinion that is a denunciation of self identity which is a terrible suicide".

${ }^{434}$ Holt and Daly, op. cit., p. 8.

${ }^{435}$ Deng and Collins (1984), op. cit., p. 128.
} 
experienced cultural behaviours of one's own environment. ${ }^{436}$ Some of the British Administrators might have expected the Hadendawa to quickly adopt their British cultural experiences and that expectation prevented them from viewing the Hadendawa as they are and what they were in their social, cultural and political environment of the eastern Sudan.

\subsection{Territorial African pagans and slaves}

In Sudan, according to the Christian Animist students from the South, the term 'pagan' is a derogatory racial description of the heterogeneous African population residing in the contemporary South Sudan, whether Christian, Muslim or Animist. Historically, these 'pagans' face 'genocide', 'ethnic cleansing' and slavery in the name of Jihad. ${ }^{437}$ According to Gray, Arabs immigrated to Sudan and commenced to impose Islamic and Arab homogeneity throughout the country. The indigenous populations of the part known today as the Northern Sudan were receptive to the assimilation into the new identity. The current indigenous inhabitants of the South, however, continued to resist this assimilation to the present day. Gray concludes that after this, the rigid Islamic concept which divides the world into two categories, Dar al Islam that is the domain of peace and Dar-al Harb, the domain of pagans was applied against the mostly Christian and Animist indigenous groups who resisted assimilation to Islam and an Arab identity. ${ }^{438}$

\subsubsection{Ethnic composition of the pagans}

Pagan African Sudan is a composition of heterogeneous groups. Their total number is reckoned to be around 572 and scholars divide them into three groups, taking into consideration linguistic similarities and customs. The largest group is the Western Nilotic group that includes the Dinka who form $10 \%$ of the population of Sudan, the Nuer with 5\%, the Shilluk with 1\%, and the Anyuak, the Acholi, the Luwo, the Bor Balanda and the Pari who are smaller still. ${ }^{439}$ The second category is the Eastern Nilotic group, which is divided into two sub-categories. The first is the Bari speaking

\footnotetext{
${ }^{436}$ Mills, Robert (1989), p. 46.

${ }^{437}$ Akot Yel, a Dinka Animist Christian, South Sudan, University of Juba: "Since the foundation of Sudan, genocide was committed by the Arab Muslims in the name of Islam, until today, they killed us during the war, because we were Dinka, Nuer and Shilluk Africans, even among us, we have Christians, Muslims and believers of Animism, yet we are all pagans". "The Arab Muslims conducted ethnic cleansing with their Jihad against us from the very beginning until now. In the name of Islamic Jihad, Ja'aleen and Danagella excluded us from administrative institutions of Sudan by killing us, because we are pagans who worship beings. We experienced Jihad, because the Muslim Arabs think that we are pagans, because we have resisted assimilation to their religion".

${ }_{438}$ Gray, Richard (1961). A History of the Southern Sudan 1839-1889, Oxford: Oxford University Press, pp. 2-7.

${ }^{439}$ Voll and Sara, op. cit., pp. 8-13.
} 
ethnic groups, which encompass more than ten tiny minorities further fragmented into six subgroups. The Bari form $2 \%$ of the Sudanese. ${ }^{440}$ The third category is known as the Ubangi-speaking and Central Sudanic speaking group and it includes the Azande, the Muru, the Ndogo, the Sere, the Mundu, the Biri Balanda, the Madi and many others. ${ }^{441}$

The interviews with the students provide us with some additional names which are not recorded in this categorisation. They include the Burun, a community that speaks at least four different Western Nilotic languages and manifests different cultural identities. Bandala, however, belongs to the 'Ubangi-speaking group and Jurbeil, who know itself as Beli or Wulu belongs to the Central Sudanic group. ${ }^{442}$ The Kachepo of Boma in the Eastern Equatoria State remains unclassified in linguistic and cultural terms, yet it can be possibly categorised as Surmic. These 'pagans' are the pariah of Sudan from the point of view of the central government.

\subsection{2 'Unsaid' discrimination}

It is paradoxical that the incessant constructions of social systems in Sudan are metaphorically political and ambiguous towards national identity in Sudan. The metaphoric arguments neglect the inherent realities of Sudan's social and political structures of ethno-linguistic and religious diversity. These fundamental facts are often not debated at national political forums and, hence, they constantly recycle and divide the people of Sudan. Deng argues that the people of Sudan have 'hypocritical' attitudes that avoid addressing the political crisis of identity. This behaviour gradually stifles the need for addressing other issues and finding alternatives. Among these issues of national identity is the question of how to manage the combination of two identities, African and Arab. Also, no clear definition has been produced concerning the relationship between religion and state. Instead, the government fuses Islamic religion with the state and thus defines a national identity based on one religion. ${ }^{443}$

Some Christian and Animist students from the South blame the central government for having entrenched political and social institutions of Sudan into a system that discriminates the people of the South. This claim comes from the answers to the questionnaire question "Have you ever experienced any form of discrimination in any region of Sudan, if so, please explain?" The students

\footnotetext{
${ }^{440}$ Ibid.

${ }^{441}$ Wai, Dunstan, M (ed.) (1973). The Southern Sudan the Problem of National Integration, London: Frank Cass, pp. 910 .

${ }^{442}$ Bulletin (1984). "Rejaf Conference Language", Bulletin of the Oriental Studies, University of London, p. 2.

${ }^{443}$ Deng, Francis Mading (1989). Cry of the Owl, New York: Lillian Barber Press, p. 1.
} 
claim that discrimination is ostensibly covered up to sound brotherly, but in essence it amounts to the exclusion of the population of the South from participating in institutions of state. In the view of these students, four political issues in Sudan remain 'unsaid'. The first of these is the term Junubi (Southerner). If a Northern Arab Muslim calls an indigenous non-Muslim from the South 'Junubi', he does not refer to the literary meaning for the term as a person from the South. Its underlying intrinsic social meaning among Muslim Arabs is an exclusive racial category term that excludes the Southerners from the social institutions of Muslim Arabs in the North. Its hidden meanings include 'lost brother', (an identity of a person that has rejected Islam); slave, destitute, sordid awesome and an outcast from the umma. ${ }^{444}$

Second, the issue of incorrect writing of the non-Muslim names is intentionally made in official documents in order to urge the Africans to abandon their traditional names, so that they are assimilated into Arab names. One student states: "Muslim Arabs write our African names wrongly and when you complain, then they respond, isum ajami (non-Arab speaking name). Personally, I understand it is a symbolic reference of indirect discrimination which is 'unsaid' in our institutions, but we understand its denotation. It means change your name into an Arab Muslim, if you want the correct orthography of your name". ${ }^{445}$

The third one is the issue of systematic discrimination by the ruling power in treating its citizens in public institutions of Sudan. Experiences of some students concerning Sudan's political institutional setting indicate to them that it operates consistently, under the criterion of racial discrimination. It rejects the principle of equal treatment of 'African -Arab' identities within Sudan. The 'African' identity can be subjected to severe discrimination while Arab identity is favoured. This feeling is partly derived from the treatment of power in Khartoum to three Sudanese politicians. Answering the question "Have you ever experienced any form of discrimination in any region of Sudan?" one Dinka student says that he has not yet experienced any political

\footnotetext{
${ }^{444}$ Arkanjelo Wol, a Dinka, University of Bahr el-Ghazal: "When a Muslim Arab student calls me a Southerner I quickly come to conclusion that discrimination is in operation and interpret it as another way of calling me an Animist who rejects Islam". Kong Puok, a Nuer student at the University of Upper Nile concludes that "The Muslim Arabs think that we do not understand their derogatory term Southerner. When they call me so here, I disown it, because, it is another way of reminding you of being a slave. In the past, the economy of the Northern Sudan was built by the Southerners to mean those slaves from the South". Dut Lual, a Jur Col, University of Juba: "I dismiss the term Southerner, because the Arab Muslims use it as a good one, but behind it, it means a sordid, destitute and awesome and hungry person from the South". Sara Arkanjelo, a Dinka Christian, South Sudan: "A Southerner seems to be a term used by the Northern Muslim Arabs in public, but it has its hidden meaning which is a description of those who are out from the fold of the Umma".

${ }^{445}$ Anei Dheiu, a Dinka, University of Juba.
} 
discrimination based on colour in Sudan. Nevertheless, he refers to the case of Sadiq Al-Mahdi who has been detained by the police several times, but exempted from physical torture, while at the same time; Eliaba James Surur and Isaiah Kualeng Mabor have experienced torture in political detention cells in Khartoum. According to the Dinka student, the reason for the exemption is that Surur and Mabor are non-Muslims and non-Arabs and both come from the South. To him, “... the three men are equal Sudanese and great politicians, but in the eyes of the government security, they are not equal; Al-Mahdi is superior as an Arab and a Muslim, but what is strange; no one says this discrimination, except the victims understand it. Mabor says that an Islamic and Arab identity could explain the exemption of Al-Mahdi from torture and Surur gives the same explanation". 446

Sadiq Al-Mahdi is a former Premier of Sudan during the democratic period of multi- party pluralism from April 1986 until the military coup of 30 June 1989. During that time Eliaba James Surur was the Head of the Union of Sudan African Parties (USAP) a composition of seven parties mainly from the South and Nuba Mountains regions. Isaiah Kualeng Mabor was a member of this organisation and a Governor of Bahr el-Ghazal region in the South. In this way they are politicians of the same status and it is a duty of power in the state to treat them equally, either to exempt them from its system of torture or if there is any obligation to torture than it should torture them all, since, after the NIF took power, detention, torture and disappearance of the opposition figures became a consistent practice in the capital city of Khartoum. Lesch explains that the National Security Guards of the NIF confiscated the buildings of the 'Bar Association' and the former office of the Electorate Commission and turned them into prisons. These buildings became "ghost houses" 447 for the detention and torture of political dissidents. ${ }^{448}$

\subsubsection{1 'Thudan' and Sudan}

The fourth issue taken up by students is the territorial name of present Sudan, which the Nilotic ethnic groups, the Dinka, the Nuer, the Shilluk, the Anyuak and the Luwo known also as Jur-Col actually call 'Thudan'. This was addressed in the answers of some Nilotic students to the question, "How did the east, west, far north and centre become the Northern Sudan Region in exclusion of the South and what does the name of your region and Sudan mean in your native language and do you experience any difficulty in articulating it? First, a Dinka student declared: "I have a big

\footnotetext{
${ }^{446}$ Mathew Bak, a Dinka Christian Animist, Omdurman Ahlia University.

${ }^{447}$ Lesch, op. cit., p. 137.

448 Ibid.
} 
problem with the name Sudan. My mother is an illiterate and she resides in the displaced camp at Muwaealla, behind Omdurman city and she really lives in her own world, which she calls Thudan, instead of Sudan and to me a suitable new name is an expedient to extricate the Nilotics from the burden of S". ${ }^{449}$ Second, Another Dinka states "The Jieng people do not understand the Arabic constructed term, Sudan. We have no ' $\mathrm{S}$ ' in our linguistic setting of sounds, so some of us call it 'Thudan', for two reasons. First, to avoid Arabisation, because using "S" which we do not have promotes assimilation to Arabic. Second, we want the name to be changed to Thudan so that it fits to our tongues". ${ }^{450}$ Third, a Nuer argues: "For me as a Naath, Sudan was a name imposed on us by Arabs. Among us the Nilotics, there is no "S", but Arabs want to make us Arabs with their sounds, yet our native speakers refuse and call it "Thudan". ${ }^{451}$ Fourth, a Shilluk states: "A Collo man communicating with another Collo person pronounces Sudan as 'Thudan' and that is a general situation to the Nilotics, because we have no ' $\mathrm{S}$ '. Recently, we understand that the intention of bringing this other alphabet to our tongue was to make us Arabs". ${ }^{452}$ Anyuak student concludes: 'Sudan means in Arabic, 'Black' and the Arabs ... refuse to be translated into English to 'Black' and the reason is to assimilate us by adopting the notorious sound ' $\mathrm{S}$ ', which is missing among us, hence we say 'Thudan'", 453

In 1978, Francis Mading Deng published Africans of Two Worlds the Dinka in Afro-Arab Sudan. Deng wanted to illustrate that contemporary Sudan is composed of many ethnic groups, yet he took two identities, the African Dinka as 'Afro' living together with the Arabs as an example. ${ }^{454}$ His choice for the title; 'Two Worlds' acknowledges the presence of two contradictory linguistic cultural identities 'Sudan' and 'Thudan' in one territorial sovereign state. This observation of the existence of 'Two Worlds' has been neglected in studies, while it presents the problem of territorial identification among the largest indigenous populations of the Nilotic ethnic groups, the Dinka (Jieng), the Nuer (Naath), the Shilluk (Collo), the Anyuak and the Luwo in South Sudan. ${ }^{455}$ The author observes that socialising and discussing politics with the Nilotic students is very easy. Nevertheless, a listener will quickly observe their territorial identity in their use of the term

\footnotetext{
${ }^{449}$ Diing Malong, Christian Animist, University of Juba.

${ }^{450}$ Makur Mading, Christian Animist, University of Bahr el-Ghazal.

${ }^{451}$ Chol Machar, a Nuer Christian Animist, University of Upper Nile.

${ }^{452}$ K. Chan, University of Upper.

${ }^{453}$ A. Gum, University of Upper Nile

${ }^{454}$ Deng (1978), op. cit., p. 1.

${ }^{455}$ Rolandsen, p. 23.
} 
'Thudan'. These conflicting territorial identities remain "unsaid" in the political forums and academic intellectual debate of the country. Three interviewed Nilotic students were asked to provide the reasons for using the name 'Thudan', instead of Sudan. A Nuer student answered that 'it is just the absence of "S" sound among the Nilotics, but the Arabs put it in assuming that we shall become Arabs, if we speak their sound, ${ }^{456}$ For an Anyuak student, Sudan means in Arabic, Black and the Arabs here refuse to be translated into English to Black and the reason is to assimilate us by adopting the notorious sound of ' $\mathrm{S}$ ', which is missing at all among us and for this, we say 'Thudan'. ${ }^{457}$ Luwo student claims that his rejection of the name 'Sudan' and adoption of 'Thudan' is to avoid discrimination in colour, because, the term Sudan means 'Black' in Arabic. He explains: 'the name Sudan is a description of the Arabs to the people of the present land, Sudan. It means "Black" and that represents discrimination in colour'. 458

Answering to the question how do you want identity of Sudan to be defined in a national constitution, the Nuer student states "I have a problem with the name 'Sudan' and I want it to be changed in the national constitution to the Nilotic Republic. All people in Sudan are attached to the Nile, but why do you name the state in colour? Sudan originated from Arabic vocabulary Bilad alSudan to mean the land of the Blacks. We know ourselves that we are Blacks with other Blacks around the world and their states are not called Blacks." ${ }^{459}$

Sharkey argues that Sudan emerged as a result of Arabisation entailing the gradual spread of both Arab identity and the Arabic language. Members of the Arab elite developed national consciousness of Arab national identity and in the process the elite adapted the term 'Sudan' for a territory, which is derived from the Arabic word for 'blackness'. Nonetheless, the name carries its previously servile connotations of the native Black populations. ${ }^{460}$

The new demands of some students to change the name of the country from Sudan to the 'Nilotic Republic' or Thudan in order to escape what they perceive as a discrimination has some links with the theoretical view of setting race as a model for constructing territorial identities of nation-states. According to Miles, races do not naturally emerge as populations in social institutions. Instead,

\footnotetext{
${ }^{456}$ Machar Lul, Christian Animist, Omdurman Ahlia University.

${ }^{457}$ Bob A Anyuak, Christian, Omdurman Ahlia University.

${ }^{458}$ Dumo Kiir, Christian Animist, University of Bahr el-Ghazal.

459 James Liech, University of Juba.

${ }^{460}$ Sharkey, Heather J (2008, December 18). “Arab Identity and Ideology in Sudan: The Politics of Language, Ethnicity, and Race, African Affairs, the Royal African Society, Vol. 107, No. 426, p. 21.
} 
there are social reasons and conditions for some social groups to resort to this illusive discourse of race and apply it as a model of building national identities. ${ }^{461}$

Although most names of states in the world were accidental results of their histories. ${ }^{462}$ The situation of Sudan is unique taking into consideration the resistance of some citizens such as students to its adaptation as a territorial identity, this makes one admit that the reconstruction is controversial. A debate on a territorial identity sometimes leads to the change of its name into another territorial identity. For instance, the Democratic Republic of Congo is a new reconstructed territorial name for the former Zaire. ${ }^{463}$ One student argues that there are no nations whose territorial national identities have been constructed on the basis of colour. Most nations put into consideration the circumstances of their environment and derive the name of a territory from that environment. The student concludes that the indigenous popular inhabitants of Europe, France, Germany, Britain and others are mostly 'Whites' and their territorial nations are not called "Whites". 464

The student's view carries empirical truth that there is no contemporary European country calls 'White'. Certainly, the indigenous population of Finland is white in skin colour and its territorial nation state is not identified by the physical appearance of the plural colour, rather than the Finns. ${ }^{465}$ If identification was to be so, there would have been no difference between the territorial Sweden and Finland, because the native populations of these two countries are Whites in colour. ${ }^{466}$ Indeed, some of the European territorial names for states originated from territorial tribal names. ${ }^{467}$ According to Hobsbawm and Ranger, most of the European nations of the nineteenth century acquired their national identities through adaptation of some traditional surroundings. Practical

${ }^{461}$ Miles, Robert (1989). Racism, London: Routledge, p. 73.

462 See Haddon, Alfred (1934). History of Anthropology, London: Watts \& Co., Ethiopia originated from the Greek word for its native citizens, aithiopos to mean burnt appearance from aitho (burn) and opsis (appearance), p.6. See Zinn, Howard (rev. ed.) (2003). A People's History of the United States, New York: Association of School Librarians. The term America comes from the Italian explorer Amerigo Vespucci in French service, p. 34.

${ }^{463}$ Health, John Everett (2005). Concise Dictionary of the World Place-Names, Oxford: Oxford University Press, p.9. Democratic Republic of Congo is a former name for the state of Zaire.

${ }^{464}$ Abdullah Salim Sadiqq, a Muslim Nuba, Nuba Mountains, University of Juba.

${ }^{465}$ Gudykunst, William B (1995). Communication in Personal Relationships across Cultures, Thousands Oaks: CA Sage, p. 34.

466 Ibid.

${ }^{467}$ Kochmann, Karl (1994). Clock \& Watch Trade Index of European Origin, Concord: Antique Clocks Publisher, p. 3 , 5, 46. France is a tribal name for the Germanic Franks; while England comes from Angles, a tribe that resided there and German (Deutschland) is a name referring to its people. 
traditions of religious heritage, ethnic languages and customs were ideologically modified and forged as entities for establishing territorial identities of groups as distinctive nations from others. ${ }^{468}$ In regard to Sudan, what prompted the earliest decision-makers in power, during those days to suspend the environmental names and favour the foreign vocabulary term 'Sudan' is mysterious and it requires analysis in order to discover the underlying reasons behind it. The current population residing in modern Sudan used to have no unified territorial identity, but that does not mean there were no environmental names for their identities. There were names used by its indigenous people. First, the Nubians who resided in Upper Egypt identified their territory as Kush and the population was Nubians or Kushites. After their conversion from Animism to Christianity, they established Christian Kingdoms. ${ }^{469}$ For the Romans, this population was called the Nubians and the territory was Nubia. ${ }^{470}$ Second, the Nilotics (Dinka, Nuer, Shilluk, Anyuak and Luwo) who live along the Nile know it in their vocabularies until the present day as 'Kiir' and the colonialist British called them the Nilotics as a translation of Kiir. ${ }^{471}$ Studies of Mawut supported by archaeological excavation demonstrate that Khartoum the site where the capital city of modern Sudan is located was the Nilotics original area of settlement. ${ }^{472}$ For the Nilotics, the confluence of the Blue and White Niles is Khartoum and its meaning is synonymous among them. Some say it is called Kiirtoum, which is a composition of two words, Kiir and toum. The former refers to the river (Nile) and the latter refers to the confluence of the two rivers, White and Blue Niles. Some say it is a composition of two words, khar and toum. Khar refers to a branch of a river (Nile) and toum means the confluence of the same two rivers, thus the location became known Khartoum. ${ }^{473}$ Third, the territory of the Beja along the Red Sea was known as 'Hadarieba' and in the fourteenth century, the Black King, Amarah Dunqas established the Kingdom of Funj and its capital in Sinnar along the Blue Nile and the territory of this Kingdom extended from Old Dunqulah in the north to Kadugli in

\footnotetext{
${ }^{468}$ Hobsbawm, Eric John and Ranger, Terrence (eds.) (1983). The Invention of Traditions, Cambridge: Cambridge University Press, p. 12, 15, 47.

${ }^{469}$ Deng (1995), op. cit., p.38.

${ }^{470}$ Erlich, Haggi (2002). The Cross and the River Ethiopia, Egypt and the Nile, London: Lynne Rienner Publishers, p. 20.

${ }^{471}$ Fage, John Donnelly (1978). A History of Africa, New York: Alfred Knopf, p. 5.

${ }^{472}$ Mawut, Lazarus Leek (1983). Dinka Resistance to Condominium Rule 1902-1932, Khartoum: University of Khartoum Press, p. 25.

${ }^{473}$ Beswick, Stephanie F (2004). Sudan's Blood Memory, the Legacy of War Ethnicity, Slavery in Early South Sudan, New York: University of Rochester, pp. 15, xi
} 
the South. Under the influence of the wealthy Arab Muslim settlers in Kush, Dunqas embraced Islam and cooperated with Muslim Arabs and overthrew the Christian Kingdoms. ${ }^{474}$

After the destruction of the Nubian Christian Kingdoms, a new phase of history had to be set and that needed a regime that interprets its reconstruction. Sociologically, every regime in the world in power seeks an interpreter that construes its truth in different categories of political forums. ${ }^{475}$ According to Deng, the Kingdom of Funj, though its origin is obscure, historians generally believed to have been Black, but during the reconstruction of Sudan, Muslim Arab settlers in the territory became the virtual decision makers in this territory and Dunqas was a nominal leader. The territorial Kingdom was officially changed from Funj (Black) to al-Sultanate al-Zerga (Blue Kingdom). Deng concludes that the change was made, under the influence of the racial ideology of Muslim Arabs in North Sudan. This group interpreted that a free person could not be black, the colour of the Negro, the potential slave. ${ }^{476}$

First, historically, the name Sudan originated from the classical Arabic vocabulary, Bilad alSudan. It has a referential meaning, where Bilad refers to lands or homes and Al-Sudd means the Black populations residing in the area extending from the Nile to the Atlantic borders. ${ }^{477}$ In this way, the research argues that there were underlying mysteries behind the maintenance of the name Sudan, synonymous with the Black, an assumed symbolic identity for slavery. First, the virtual Muslim Arabs that interpreted the political power divided the territory into two; the land of the free and the land of un-free (slaves). The former refers to the Black Muslim inhabitants who had received their freedom and were identified as Zerga (Blues). The latter defined the population that lived in the territory, but not free, since they were not Zerga. Second, the interpreters of power, the Muslim Arabs might have hoped that their presence among the Blacks (slaves) and Zerga was a temporary one and had not thought of remaining as permanent citizens to be identified in the long course of time with the Black groups in the country as 'Sudanese'. The issue of families left behind in the arid Arabian Peninsula and Egypt was an adequate reason for them to live in hope of return to the homelands as all forms of connections were still strong and intact with their homelands. ${ }^{478}$ Third, the interpreters might have feared that an inclusive reconstruction of the territorial identity as

\footnotetext{
${ }^{474}$ O'Fahey, Rex Sean and Spaulding, Jay L (1974). Kingdoms of Sudan, London: Methuen \& Co. Ltd, p. 23.

${ }^{475}$ Foucault, Michel "Power Knowledge" in Colin Gordon (ed.) (1980). Power/Knowledge: Selected Interviews and Other Writings, New York: Pantheon Books, p. 131.

${ }^{476}$ Deng (1995), op. cit., p. 40.

${ }^{477}$ Lewis, Bernard (1990). Race and Slavery in the Middle East, Oxford: Oxford University Press, p. 50.

${ }^{478}$ Deng (1995), op. cit., p.40.
} 
Zerga would have set every territorial resident from the colour of black (slave) to the category of free men and women (Zerga). In Clarke's view, Muslim Arabs in Sudan dropped the business of ivory and gold and resorted to the trafficking in the Black populations as slaves, because the demands for slaves in the Arabian Peninsula and Egypt was increasing to a large scale. ${ }^{479}$

Recently, the descriptive identity, Sudan has been restored in political discussion. According to Deng, Some Muslim Arab scholars and statesmen from the North think there should be a better national territorial name, than Sudan. Some of them have proposed alternative names that might suit the real structure of a free Muslim Arab identity, than the identity that associates them with Negro Africans, the downtrodden of our planet. Among the proposed names include the original legacies of the historical civilisation of Old Kingdoms of Nubia, Kush and Funj . ${ }^{480}$

The intentions for the search of a new territorial name other than Sudan at present may differ; however, it not only emancipates Muslim Arabs, but also the Nilotics. The researcher observes that most educated Dinka students continue to acquire the transmitted sound of ' $S$ ' and occasionally some of them manage to articulate the territorial national identity as Sudan. This is not possible for the illiterate Nilotic community, instead the country is 'Thudan' and its population is the 'Thudaniith' to mean the Sudanese. Yet, the name Kush carries the sound 'S', but in the Nilotic orthography, '-sh' stands for ' $\mathrm{C}$,481 and Kush would appear Kuc. Generally, any possible revival of old names or any other constructed new name to substitute the name Sudan remedies the Nilotic population from 'Thudan' and Thudaniith otherwise, they will continue with their territorial identity of Thudan, instead of Sudan. Yule observes that people are not capable to articulate sounds that are not in their linguistic property. Each group has "unique properties" One of these properties is 'displacement'. It is an attempt of people to speak about things, which are totally missing at their immediate cultural environment. Displacement is an opposition to the linguistic property called cultural transmission, which is an acquisition of a language as a cultural property from social surroundings. ${ }^{483}$

479 Clarke, Peter (ed.) (1990). The World's Religions Islam, London: Routledge, p. 65.

${ }^{480}$ See Deng (1995), op. cit., p. 37 see Yule, George (1985). The Study of Language, London: Oxford University Press, p. 23.

${ }^{481}$ Nikkel (2001), op. cit., pp. 1-2.

${ }^{482}$ Yule, op. cit., p. 45.

${ }^{483}$ Ibid. 


\subsubsection{Promises of equality and federal system}

In the view of some students political developments in Sudan demonstrate that the issue of the relationship between state and religion as well as the sharing of power and wealth do not fall into the category of 'unsaid' ideological practices of power in state. They have been 'said' and negotiated in political conferences and alternative resolutions for them have been found and agreed. Yet the successive governments dominated by Muslim Arabs fail to respect such agreements by violating them and the crisis of national identity between the African and Arab identities continues. These claims by the students are expressed in answers to the question, how do you want national identity of different regions in Sudan to be defined in a national constitution, and under what system suits Sudan best and why you think so? A Dinka student argues that: "Every system under the control of the sons of our sisters, Muslim Arabs is bad; it applies classical marginalisation of the South in terms of equal development. In a political debate in Juba Conference for the issue of the relationship of the South with the North, British colonisers proposed that the South was undeveloped and was not necessary to be independent by then. When the Muslim Arabs heard that they reacted and shouted; no; no; we would develop it, but they fail to fulfil their promise. From that time until today, the South remains without roads, bridges, agricultural schemes, health centres and schools". ${ }^{484}$ The Conference in question was held on 12 June 1947 in Juba, a city in South Sudan. The British Civil Secretary in Sudan James W Robertson summoned the Chiefs from the South and some prominent figures among Muslim Arabs of the North to attend it. During the opening session, Robertson reiterated that the policy of British regarding the South is to act upon the facts that the people of the South are distinctly African and Negroid. Only political geography and economic situation combined them with the North. This situation required assurance from the political force of the North that the South will be developed in the future, so that the two territories become educationally and economically equal. ${ }^{485}$

This study argues that in Sudan power attracts the people of the South, during any political discussion that threatens the territorial unity and presents economic promises to attract the population of the South. The indigenous people of the South regard the introduction of

\footnotetext{
${ }^{484}$ Ahmed Surur, a Dinka Muslim, University of Juba states "When the British left in 1956, the Muslim Arabs defined the South as a part of the Northern Sudan and stated that they would develop it, but in practice, they assumed power and imposed their policy".

485 Juba Conference 12 June 1947 EP/SCR/1.A.5/1 Juba, 21 June, 1947, Deputy Governor of Bahr el-Ghazal/ Area, Wau p. 12.
} 
developmental projects in the South as something that would make them independent actors within their region than being sub-ordinates citizens. Beniah Yongo-Bure argues that, whenever the people of the South plan to break away from the North, the political North offers them small independent projects. ${ }^{486}$ For Dau Akol, a Southern Dinka Christian Animist, “... after the SPLM and NCP signed the Comprehensive Peace Agreement in 2005, Khartoum promised to make unity attractive through development. Currently, the NCP has forgotten its promise. At least we had expected it to revive our companies and projects of Kapoeta Cement Factory, Foundry, Fruit Processing Plant, Nzara Agriculture Production Corporation, Wau Fruit Canning Factory, Tonj Kenaf Project, Wau White Nile Brewery Project, Melut and Mangalla Sugar Cane. The resumption of those defunct companies would have made unity attractive for me. Today, unity is primarily unattractive an woman for me ..." ${ }^{487}$ On the issue of power distribution, a Nuer student argues: "During the decolonisation process, the Muslim Arabs agreed to offer us our own federal government in the South that would protect our cultural identity from assimilation to Arab and Islamic culture. Strangely enough, after the British left, they unanimously rejected the offer of the federal system to the South and set the policy of Arabising and Islamising us as an alternative." ${ }^{488}$ Johnson points out that, before the independence of Sudan, the political forces in the South demanded the provision of exceptional power based on a federal system as an alternative resolution to the re-unification of the North and South. They claimed that such a system would protect their traditional values of Christianity and Animism from assimilation to the Islamic and Arab culture. After a long discussion the Northern Muslim Arab politicians accepted this demand, but shortly after independence, they rejected its adoption in the South, under the claim that federation was the first step for the separation of the South from the North. ${ }^{489}$

\subsubsection{Status of women in Sudan}

The status of women in Sudan divides students into two factions, which appear in the answers to the question, "What are the fundamental duties of faithful ones in your religion and is there any division of roles in terms of gender?” A Nuba student argues: “... our African Islam places women

\footnotetext{
${ }^{486}$ Yongo-Bure, Beniah "Economic Reforms in South Sudan" in Martin Doornbos et al. (eds.) (1992). Beyond Conflicts in the Horn: The Prospect for Peace, Recovery \& Development in Ethiopia, Somalia, Eritrea \& Sudan, The Hague: Institute of Social Sciences, p. 166.

${ }^{487}$ Dau Akol, Dinka Christian Animist, University of Bahr el-Ghazal.

${ }^{488}$ Gai Deng, a Nuer Christian Animist, University of Upper Nile.

${ }^{489}$ Johnson (2003), op. cit, p. 34.
} 
on the same level with men, but the problem here is with our Arab Muslim fundamentalists. They... continue to apply the primitive tradition that had placed the women in an inferior category. In

Khartoum, Muslim fundamentalists have revived their traditional discrimination of women. ${ }^{490}$ Another student states: "In the Northern Sudan, women are segregated ... on the streets, in cafeterias, at universities, in hotels, in public transports, to the extent of forcing them to sit separately in buses, and when you ask about the reasons for this inequality, then, religion is the scapegoat to be the source of this inequality. ${ }^{491}$ One Nuba concludes that: "The government has failed to digest that Prophet Muhammad had freed the women, by prohibiting the discriminatory killing of female children. In Khartoum no one cares to interpret ... Quran and Sunna for our equality, except in Nuba Mountains, where we are all the same, no segregation, our Islam is connected with our traditions and customs, which reject discrimination against women". ${ }^{492}$ On the other hand, a Muslim Arab student answers the same question argues: "Sharia organises social setting of Muslims, where women know their statuses and the same to men and those are in our constitution in Sudan. Some Muslim women at our university ... fail to follow the obligations of Sharia by dressing immodest clothes and by rejecting scarves on their heads". 493

The absence of political vision among the political forces in power to address such religious and ethnic cultural differences as realities divides the Muslims in Sudan, but they have not seriously set an open political dialogue in order to find a solution for this reality. Nuba Muslim leader Yusuf Kuwa Makki provides an example of the divisive experiences which originate from conflicting identities between Muslim Africans versus Arab Muslim traditions. He states that, while he was still a student a discussion took place in the class over the subject of women's rights in Islam. In the view of Muslim Nuba students in the class, Muslim women deserve the same equal status with men in public institutions by contesting and voting in national elections, but Muslim Arab teacher opposed such views and reacted; "women's rights; why should they be given any rights?" ${ }^{494}$ In theory, culture is a source of discrimination against women. According to Marler, in the feminists' view, the transition from the cultural system of feudalism to industrial revolution has shifted a woman from being culturally limited as a "primary (re)producer of children and religious piety in

\footnotetext{
${ }^{490}$ Walid Hussen, University of Khartoum.

${ }^{491}$ Hamed Zuman, Omdurman Ahlia University.

492 Ahmed A, University of Juba.

${ }^{493}$ Saleh Ahmed, University of Khartoum.

${ }^{494}$ African News (2001, April). "Yusuf Kuwa Mekki, Life Is a School with Great Lessons", African News, Issue No., 61, pp. 1-2.
} 
the domestic or private sphere" to equal opportunities in the most public and private institutions with male in the West. ${ }^{495}$

This author argues that it is the culture which each group has adopted that constitutes their views on equality and inequality between women and men in Sudan. Some Muslim women in Sudan accuse the present government of promoting violence and discrimination against women. Amnesty International organised a conference on human rights in February 2005 and invited a Sudanese woman, Asma Taha to address the conference. Taha urges the Government of Sudan to "stop violence against the women". ${ }^{496}$ The legislature has contributed on the larger scale to the derogatory status of women in Sudan. Public Order Law (POL) of 1991 with article 153 limits women's dress. On 3 July 2009, Police of Public Order (PPO) entered into a popular decent restaurant in the centre of the capital city Khartoum and singled out thirteen women from the restaurant. The police accused them of having attired themselves in pants; which is a form of a dress the law defines as indecent and obscene for women to wear in public places. Out of the thirteen, ten were flogged forty lashes, fined and discharged after two days in police custody; meanwhile, Lubna Ahmed Hussien and two others rejected flagellation. Hussein argues: "I am not afraid of flogging .... It is about changing the law that discriminates us, it is un-Islamic". 497 The case of Lubna Hussien provoked the French President Nicolas Sarkozy and he invited her to come to France for protection. ${ }^{498}$ Legally, Lubna could not freely board a plane from Khartoum to Paris. The 'Nationality Act' of Sudan limits women's mobility. A woman is not free to cross the territorial boundaries of Sudan without the approval of her parents, a brother or a husband, if married. ${ }^{499}$ Despite this limitation, Lubna escaped to the Yemeni capital, Sana'a, while ostensibly attired in niqab, a large piece of fabric cloth that cloaks the body from head to toe with a mesh or a small patch of gauze to see out. Lubna explains: "They wanted to prevent me from leaving I resorted to the niqab and managed to leave. I requested documents to be able to travel, and this is the only means I found to be able to leave Sudan". ${ }^{500}$ Lubna announced in Paris her published book entitled

\footnotetext{
${ }^{495}$ Marler, Penny Long "Religious Change in the West: Watch the Women" in Aune, Kristine et al. (2008). Women and Religion in the West Challenging Secularization, Hampshire: Ashgate, p. 23.

${ }^{496}$ McWilliams, Mike (2005 March, 21-22). “Advocate to Spread Views Globally Asma Taha Fights for Women's Rights”, Iowa City Press Citizen, Pheasant Ridge Neighborhood Center, p. 1.

${ }^{497}$ Sudan Tribune (2009August). "Lubna Hussien Trial", Sudan Tribune English Newspaper, Vol. 3, Issue No. 78 , p. 1.

${ }^{498}$ AFP, (2009, August 23). "Sarkozy Sympathy to Hussein in Sudan”, Agence France Press www. afp.com/afpcom/en.

${ }^{499}$ Sudan (1994). "Sudan Country Study", Washington, DC: Department of the Army, p. 1, 18.

500 Sudanese woman (2009, November 23). "Sudanese Woman Praised for Fighting Pants Law", www. sudaneseonline.com.
} 
Forty Lashes for a Pair of Pants. French Foreign Minister, Bernard Kouchner in a joint Press Conference with her rejects the violations of all forms of rights, and specially the rights of women. He states: "We are all concerned by this (situation) because the subject of the violation of human rights, particularly the rights of women affects us all". 501

As this author is a participant observer to the status of women under this law in Sudan, a number of the government official men constantly issue directives urging female students and women in government offices, universities and public places to attire themselves according to what they always prescribe as 'an Islamic dress code'. In fact, these codes entail only wearing a veil or a scarf covering the head without legal provision defining clearly the acceptable dress that fit women, beyond the veil or scarf. Instead, the law grants the PPO unit virtual immunity from prosecution, even though on too many occasions, the unit applies uneven treatment on the woman accused of immodest dress, before she could reach a criminal court to face flogging.

\subsubsection{4 (In)compatibility of religions}

A Muslim Nuba student argues that: "All the universal religions have a common source. They come from God, the Creator of the universe and most of us as African Muslims, particularly in Nuba Mountains understand this reality and we have no religious conflicts. Animists, Christians and Muslims co-exist, but Arab Muslim fundamentalists of the National Congress reject this tolerance and accuse us ... as pagans in the region". 502

The claim that religious co-existence is interpreted as a promotion of pagan religions in Nuba Mountains represents a paradigm of racism in the public institutions of Sudan. It indicates that Islam in Sudan has not been regarded as a unifying principle. It involves racism, where some Muslims are defined as pagans due to their ethnic background. In response, Yusuf Kuwa Makki as a politician has sought a political dialogue in order to find alternative resolutions for religious compatibility in Sudan. He argues that the classification of the non-Arabs, whether Muslims, Christians or Animists as pagans in Nuba Mountains has affected his political attitudes and that dictated him to seek an alternative that might remedy the racial discrimination within the Islamic institution of North Sudan. He argues: "We want to retrieve the role of the indigenous religion of

\footnotetext{
${ }^{501}$ French Minister (2009, November 25). "French Foreign Minister Praises Courage of Sudan's Trouser Journalist", Sudan Tribune English Newspaper, http//www.sudantribune.com.

502 Tabelo Ibrahim, University of Khartoum.
} 
Animism in Sudan, but this choice contradicts with my faith as a Muslim, because I still feel I am a Muslim".503

In essence, such expression indicates the acknowledgement that being a Muslim is incompatible with Animism. Islam recognises only the believers of Christianity and Judaism as followers of the Book. ${ }^{504}$ So, that was a dilemma moment for Makki as a Muslim, he could not combine two practices which his own religion rejects. This situation pushed him to seek a further alternative resolution. Yet, there was no solution, beyond the experience of the Former President Julius Nyerere of Tanzania which exposes the practical compatibility of Animism and Christianity in African ritual worship. Nyerere's 'Let Us Run While They Walk' was an alternative. Makki says that the religious experience of Nyerere has taught him that Islam and Animism could be practiced compatibly as religions. Nyerere writes that when he was twelve years old he became a Christian and believed in Christianity. Still, he continued to believe in African religious rituals as he explains: "I became a Christian when I was twelve years old and I believe in Christianity. Still I believe that we Africans have our own rituals". 505

In fact Nyerere unveils his dualistic religious identity; although he identified himself as a Christian, he continued to participate in African Animistic religious rituals. He explains that one time he accepted one of these rites to be performed on him. As a young chap, he returned with his stepmother from the religious funeral of Animism with a goat handed to them by the relatives of his stepmother. On the way, he faced a difficulty in pulling the goat, as he was very young. This difficulty was relieved religiously as a certain African man performed an Animistic religious rite, which reconciled him with the goat. The rite was that the man took some hair from the head of Nyerere and snatched some hair from the goat and mixed them together, surprisingly the result was that the goat cooled down and followed Nyerere without resistance, until he arrived home. ${ }^{506}$

The performance of this African religious rite reveals the religious identity of Nyerere as he was both a Christian and a believer in Animism. The research calls a religious person who practices Christianity in compatible with Animism 'a Christian Animist'. The procedure of this worship suspends some Biblical obligations, which reject any performance that could be interpreted as

\footnotetext{
${ }^{503}$ Op t' Ende (2001), op. cit., p. 2.

${ }^{504}$ Holy Quran (Surra al-Maidh 5:48).

${ }^{505}$ William, Edgett Smith (ed.) (1971). We must Run while They Walk, New York: Random House, p. 35

${ }^{506}$ Nyerere, Julius Kabarage (1977). Ujamaa: Essays on Socialism, London: Oxford University Press, p. 18.
} 
irrelevant to the Christian teaching. ${ }^{507}$ Nyerere suspended some typical interpretations of the Bible and chose tolerance to both religions and internalised them as his religions. In contrast, Makki promulgates this way of beliefs exist in the Nuba Mountains, as kujur (Animistic religious rituals). The people of Nuba Mountains perform these rites in public and it is difficult for the audience to explain the relationship of their physical performances and the results they produce. For example, one time, a serious drought came and the Nuba Muslims and Animists had to inform the kujur to intervene. Those with these ritual powers performed their religious creed and indeed, a short time after their performances the rain started to drop down in abundance. ${ }^{508}$

Strict teaching of Christianity rejects any ritual performance not related to the tradition of the Church. The Holy Bible instructs Christians that: "You shall have no other god before Me; you shall not make for yourself a carved image or any likeness of anything that is in heaven and above or that is on the earth". ${ }^{509}$ In practice, some African Christians suspend certain interpretations of the Bible and choose tolerance to both religions, Animism and Christianity as fitting to their social environments. For Makki, such suspension of strict applications of Islam and Christianity exist in African beliefs among the Nuba people of Nuba Mountains, as kujur. ${ }^{510}$ The presence of Animistic beliefs among the Nuba might have motivated some Nuba students to support the creation of a constitutional system that contains this religious diversity as some of them argue: "If we take alone Islam as the source of legal code, then what would the country do with the Nuba". ${ }^{511}$ Another said: "In Nuba Mountains a person could be a Muslim or a Christian and continue to practice Animism". ${ }^{512}$ Some Muslims in Nuba Mountains argue and propose the possibilities of combining Animism with Christianity, Judaism and Islam. The logic behind this compatibility of the four religions is that 'religion is one'. 513

The concept of oneness of God is common to all three religions, Christianity, Judaism and Islam; however, divergences are found in the organisation of social lives. In response to the question do you think that inter-marriages can curtail regional diversity in Sudan, and if so, what marriage do

\footnotetext{
${ }^{507}$ Holy Bible (Exodus 20:3-4).

${ }^{508}$ Op t' Ende (2001), op.cit p. 2

${ }^{509}$ Holy Bible, (Exodus 20: 3-4).

${ }^{510}$ Op t' Ende, op. cit., p. 2.

${ }^{511}$ Usman Farej, University of Khartoum "We have our traditional religions which the Muslim Arabs distort as kujur, but any system that seeks tolerance, then they cannot be left out from constitutional codes".

${ }^{512}$ Ismael Abdul Mullah, University of Juba.

${ }^{513}$ Op t' Ende, op. cit., Yusuf Kuwa Makki”, p. 2. Yusuf argues that the African religious traditions of the ancient Kush and Meroe, before the arrival of Islam to Sudan and the recent Islamic Tiqali Kingdom should be put in constitution and taught in school; after all 'religion is one'.
} 
you prefer and explain why? Ali Abdel Muneim an Arab Muslim student responds: "Marriage in Islam is very important; a pious Muslim could marry everywhere, including heaven, if he dies in defence of Islam". 514 The discourse of marriage in heaven has been a dominant claim among senior figures of the Government of Sudan, under President Al-Bashir. According to Mahmoud, in Sudan, Muslim leaders of the NCP celebrate ceremonies of marriages in heaven on the ground. They do this, under the belief that the Muslim soldiers killed on the battlefields in the South died in defence of their religion, Islam. Thus, they are identified as martyrs in the name of religion, and are automatically married to houris (paradise virgin women). ${ }^{515}$

In contrast, this belief is in conflict with the view of Christian students. One of them states: "President Omer Hassan Al-Bashir claims that the dead Muslim students in the South, Nuba Mountains ... and other places, during the war have had their marriage in heaven. This deception motivated some of my Muslim friends to aggregate into the South to acquire women in heaven. In my Christian faith, social marriage ends on the earth. Therefore, we do not fight for sexual aims in heaven". ${ }^{516}$ Some Christians and Animists from the South accuse the present ruling party, the NCP of being in anti-religious co-existence. It encourages a derogatory characterisation of the nonMuslim religions in the country. This claim can be seen from their responses to the question: "How many festivals do you celebrate in your religion; where and how do you offer sacrifice and do you face restriction or limitation of worship in anywhere within Sudan?" One of them argues: "The national Congress Party is too Islamic and that blinds it to act as a ruling party to maintain different religions in harmony. It teaches its allies to see themselves as superiors in the way of their worship and for that they characterise the contrary worship of the people of the South as uncouth". 517 Another student adds that: "In Sudan, the National Congress of Al-Bashir fails to understand being an Animist Christian does not mean pagan. We tell them we are not pagans; we are Christian Animists, we profess Animism and Christianity compatibly". ${ }^{518}$ Many interviewed students from the South identified themselves as both 'Christian and Animist' and gave explanations concerning the compatibility of these religions. For instance some students argue "Christianity is a good religion; it accommodates somehow the Dinka traditions and Islam rejects all forms of our identity that is our customary way of life; ... we are very religious, but do not fit with Islam, which is

\footnotetext{
${ }^{514}$ Ali Abdel Muneim from Shaiqqyyia, University of Khartoum.

515 Suliman Mohamed, Suliman (1999), op. cit., p.3.

${ }^{516}$ Santino Dau, a Dinka Christian Animist, University of Juba.

${ }^{517}$ Gatwitch Bechok, a Nuer Christian Animist.

${ }^{518}$ Paul Ataidi, an Anyuak Christian Animist University of Juba.
} 
extremely external and un-free of Arab traditions and customs". ${ }^{519}$ Another concludes "Christianity allows me to attend the church's offerings as a Christian and simultaneously, I attend the offerings of Jieng Animism, as an Animist, therefore, I ... feel not displaced from my tradition, since I am both a Christian Animist". ${ }^{520}$ In the view of de Waal, the ruling Muslim political organisation of Sudan, NCP former NIF has no reconciling political strategy for ethnic pluralism. It has constituted a system at the national level, where Islamism became a hostage to Arab racism and ethnic politics. This racial attitude motivated some indigenous ethnic Muslim MPs from Darfur in 1988 to abandon the NIF claiming that the NIF is not free from the Arab tradition of racism. ${ }^{521}$

It is very common that scholars refuse to characterise the population of the South of Sudan either entirely as Christians or Animists. The usual and common religious descriptions are expressed simultaneously as 'Christians and Animists'. ${ }^{522}$ This expression is meant that the indigenous population residing in the South is composed of baptised Christians and followers of Animism. Such descriptive religious identity is partly true and partly untrue. Students' responses to the question: Your religious affiliation or identity $a$. Christian, b. Muslim, c. Animist d. Christian Animist e. Muslim Animist' f. Agnostic g. Any other, provide simultaneity. The Nilotic and some Nuba students argue that they practice Christianity and Islam compatibly with Animism in their worship. For this reason, the majority of them identify themselves as 'Christian Animist' and 'Muslim Animist'. 523

This religious compatibility obliges one to identify most of them in accordance to their given religious identity as 'Christian Animist', rather than 'Christians and Animists' and 'Muslim Animist'. The former defines a baptised Christian or a converted Animist to Islam. Yet, he or she practices Christianity or Islam compatibly with Animism and the latter identifies the baptised ones, the 'Christians' and the non-baptised ones are 'Animists'. Two scholars provide more plausible compatibility of religious structure in South Sudan and Nuba Mountains. First, Johnson argues that the civil violence in Sudan is described as a competition between the prophetic religions, Islam and Christianity. Under this description, the people of South Sudan are not projected as people with

\footnotetext{
519 Justin Juac, a Dinka, University of Bahr el-Ghazal.

${ }^{520}$ Juac Ater Mou, University of Juba.

521 de Waal (2004), p. 98.

${ }^{522}$ Hentoff, Nat (1996 August 20). "Here is the Proof, Mr. Farrakhan”, Village Voice, Vol. 41, Issue 34, p. 10. The Black people in the South of Sudan as Christian Animists.

${ }^{523}$ Kuc Deng, a Shilluk Christian Animist, University of Juba, "Christianity and Animism are very close, so I practice them side by side". Rabi Hussein, a Nuba Muslim Animist "I pray at the Mosque and I attend traditional rituals of my grandfather on our hills in Omdurein"
} 
their own coherent religions; instead anthropologists described them with "depressing regularity as 'Christian and Animists' or sometimes even 'Christian animists"'. ${ }^{524}$ Second, Ewald observes that in Nuba Mountains, some Muslims perform African traditional rituals to secure rains, good harvests, and traditional medicines for the Nuba people. The Islamic North, however, describes this form of religious performance as a pagan practice and believes it is necessary to convert this population to strict Islamic cultural identity, but the implementation of the conversion encounters the dilemmas between economic interest to own the non-Muslims as slaves and converting them to Islam. $^{525}$

\footnotetext{
${ }^{524}$ Johnson (2003), p. xvii.

${ }^{525}$ Ewald, Janet J (1990). Soldiers, Traders, and Slaves State Formation of Economic Transformation in the Greater Nile Valley 1700-1885, Wisconsin: University of Wisconsin Press, p. 15.
} 


\section{DILEMMA BETWEEN ISLAM AND WEALTH}

Some Muslim students blame the Christian and Animists of the South in resisting conversion of the 'pagan' population in the South and Nuba Mountains to Islam. For instance, Muhammad Al-Tom states: "The elite Christians in the South are responsible for the failure of Islam to convert the pagans in the South into an Islamic faith". ${ }^{526}$ Another argues: "The British imperialists prevented the Muslim Arabs to convert the pagans of the South and Nuba Mountains to join their brothers in Islam". 527

In contrast, Christian Animist students claim that, if Islam was introduced in an appropriate manner from the very beginning, the Animist population in the South would have embraced it as their religion, but slavery and looting of cattle and other atrocities stimulated them to reject Islamic faith. The students argue: "Our problem with Arab Muslims started, since the time of Muhammed Ahmed Al-Mahdi system of Mahdism, which was a regime that ... had legitimated the Muslim Arabs to enslave us and kill us. Mahdism classified the citizens into slaves and slavers and without the British who created a law that prevented them to enter the South we would have had all disappeared to different markets of the slave trade". ${ }^{528}$ Another student states: "Today the ruling party, NCP thinks that the religious and ethnic diversity is a sin; it is an infidel system and for that it dislikes British colonialism for maintaining it". ${ }^{529}$ Furthermore, one student concludes: "For us, we love British people ... their system of colonialism rejected later slavery and closed the South from Arab slavers. These Arabs were not for religion, Islam but were ... searching for wealth; thus they spoiled the world of peace by enslaving us and looting our cows". ${ }^{530}$ According to Ewald, Muhammad Ahmed, a Muslim faqih (Islamic cleric) promulgated himself to be the Mahdi, a divinely pious Islamic leader who would unite and purify the Muslims and convert the infidels as a preparation for the end of the world. In practice, this divine message turned out to be a total devastation of the non-Muslims Black communities in Nuba Mountains and beyond. Ewald

\footnotetext{
${ }^{526}$ Muhammad Al-Tom, University of Khartoum, Kababish, North Kordofan region.

${ }^{527}$ Halla Saeed, Muslim, University of Khartoum.

${ }^{528}$ Agoth Ater, a Dinka, University of Juba.

${ }^{529}$ Mayik Akol a Dinka, University of Juba.

${ }^{530}$ Ayen Kur, a Dinka Christian Animist, University of Juba.
} 
concludes that Al-Mahdi legitimated trafficking in civil populations in Nuba Mountains and South Sudan, where his Ansar (followers) were mostly free to loot and act in a theocratic way. ${ }^{531}$ Islam as a religion is defined in the Quran as an eternal path for peace. ${ }^{532}$ However, its contradictory propagation of its propagators that juxtaposed conversion, looting and killing of the Animist population of South Sudan and Nuba Mountains has constructed a collective derogatory vocabulary among the victims of looting and murder. The Dinka describe the time of Muslims' arrival to the South as 'the time when the world was spoiled'. The Ansar murdered the Animists, looted tools of their livelihood and at the same time testified that 'there is no God, but the One God and Muhammad is God's Messenger'. Two scholars write about these conflicting performances of Muslim Arabs in South Sudan. First, Deng says that he interviewed in 1973, some Dinka Chiefs who had experienced this situation, including Chief Makuei Bilkuei. This Chief in his nineties testified: "It was the Ansar (Mahdi missionary followers) who destroyed the country ... That is what is called the spoiling of the world ...Yes, (they) would come with camels, and donkeys and mules and guns ... That is how they killed people ... (They destroyed areas until they reached us here. They took the people and sold them ... They said, 'la Illa, ila Allah, Muhammad Rasul Allah (There is no God, but the One God and Muhammad is God's Messenger). That was the way they chanted they slaughtered and slaughtered and slaughtered". ${ }^{533}$ Second, Nikkel explains that the oral tradition of the Dinka recalls the time of harmony, when the world was at peace and mankind flourished with vast herds of cattle. To the Dinka, this state of affairs was irrevocably altered, when the Jellaba of Shaiqqiyyia, Danaqla and Ja'aleen Muslim Arabs of North Sudan penetrated their county of Bahr el-Ghazal and Upper Nile of South Sudan as people of Islam. However, they set them into slavery and looted of their cattle. Nikkel concludes that the Dinka describe that time of destruction in their oral narrative as "the time when the earth was spoiled." 534

There exists a grave contradiction between the idea of giving the new religion, Islam to the Animist population of the South and the looting of their cattle and imposition of slavery. Although slave trade fundamentally has little to do with Islam or any religion, beyond economic exploitation $^{535}$, Islam as a religion in Sudan was and is today a symbol of slave raiders to the Animists of the South. The population of the South intertwined Islam with the first and present

\footnotetext{
${ }^{531}$ Ewald, op. cit., p. 118-120.

${ }^{532}$ Holy Quran (114:6236).

${ }^{533}$ Deng (1995), op. cit., p. 75

${ }_{534}$ Nikkel, op. cit., pp. 50-55.

535 Jok, op. cit., p. 74.
} 
attitudes of Muslim Arabs in power towards them as the authentic nature of Islamic religion. Those attitudes have serious negative impacts on the Islamic religion in the South. Tow scholars show earlier and current Muslim approaches to the Christians and Animists of the South. First, according to Gray, traditional Islamic views in the North sanctioned enslavement of the converted Muslims and that contributed to the acceptance of the age-old slave raiding to the South to enslave the pagan people of the area. Slavers took slaves, married from these pagan tribes and established themselves as a ruling caste. Today, slavery has resulted in an embittered relationship between the Animists of the South and Arab Muslims from the North. The population of the South view Muslim Arabs as the cause of their long suffering and the hardships of their present life. ${ }^{536}$ Second, An'Naim argues that it is abhorrent for the current Islamic government, under Al-Bashir to continue sanctioning slavery today. The fact that slavery is permissible under Sharia does have serious practical consequences not only in perpetrating negative social attitudes toward the former slaves and segment of the population that used to be a source of slaves, but also in legitimizing forms of secret practices akin to slavery. In the Sudan, for example, images of slavery under Sharia and Islamic literature continue to support negative stereotypes of the Sudanese from the Southern and Western parts of the country, which were sources of slaves, until the late nineteenth century. Moreover, recent news reports indicate that Muslim tribesmen of the southern western Sudan feel justified in capturing non-Muslims from South Sudan and keeping them in secret slavery. ${ }^{537}$

In practice both past and present times, Muslim Arabs in Sudan have been in constant dilemma. Historically, few Muslim slave traders thought that it was significant to convert the pagan tribes in the South into the domain of Islam. The majority preferred the acquisition of wealth through slave trade and slavery of the pagan tribes to conversion, because, theoretically, Islam illegalises Muslims to own other Muslims as slaves. According to Deng, in the beginning, the Muslim Arabs in Sudan were faced by with a dilemma, between Islam as a religion and economy. Islam teaches Muslims to avoid enslaving other Muslims, while the economy of the ethnic Arab Muslims in Sudan and their Christian forerunners of the Nubian kingdoms were built on trafficking in Black slaves from South Sudan. For that reason, Muslim Arabs avoided the Islamisation of the Southern Sudanese Animists. ${ }^{538}$

\footnotetext{
${ }^{536}$ Gray, op. cit., p. 46.

${ }^{537}$ An'Naim, Abdullahi Ahmed (1990). Towards an Islamic Reformation: Civil Liberties, Human Rights and International Law, New York: Syracuse University Press, p. 175.

${ }^{538}$ Deng (1995), op. cit., p. 25.
} 
The illegalisation of Islam to the enslavement of a converted person into Islam is a controversial subject-matter in academic debate of national institutions in Africa. According to Lewis, some Black Muslim Africans from the oasis of Tuat, Mali submitted a petition to Muslim jurists seeking the reasons for wide spread enslavement of Muslim Africans in the area. The response to the petitioners was a lecture derived from the provisions of classical Islamic interpretation towards the legality of slavery in general. It was explained to them that all Muslims and infidels residing, under the protection of Muslim society are exempted from slavery; however, heathens who are captured in Jihad must be subjected to severe slavery. The social status of such a group does not change, even though they subsequently embraced Islam and became Muslims. ${ }^{539}$

In contemporary Sudan there are an enormous number of documented scientific references which unfold the presence of slavery in its national institutions. ${ }^{540}$ In Sudan it is possible for a Muslim Arab to enslave a Muslim African, but what are incomprehensible are the status of historical pagans captured through the Jihad from Nuba Mountains who embraced Islam, as well as the status of their children born and raised as Muslims. Ewald notes that at the past Black ethnic groups, the Nuba were Animists and the majority of them converted to Islam through the method of violence. Muslim Arab men from Kordofan viewed the area of the Nuba as a field for religious proselytisation. In practice, the interest in converting them has been in conflict with the interest of some Muslim Arabs to enslave them. Ewald concludes that currently, the Nuba converted from Animism to Islam still experience slavery under Muslim Arabs. ${ }^{541}$

The social relationship between the Muslim Nuba and Muslim Arabs demonstrates that, even though some Nuba became Muslims, a Nuba Muslim could still experience slavery. For instance, Mende Nazer from Nuba Mountains identifies herself as a Muslim. We cannot know how she became a Muslim between the two ways of conversion, forced to admit Islam through the Jihad and free optional conversion. She, however, tells her story in the book as a young girl, a Muslim Arab master put her into the live of slavery in 1990. She was redeemed from this type of servitude by the British organisation, 'Christian Solidarity'. Nazer is a co-author of the book Slave, the True Story of a Girl's Lost Childhood and Her Fight for Survival. The book is translated into Finnish and throughout the chapters, Nazer narrates, the circumstances of her capture, physical and

\footnotetext{
${ }^{539}$ Lewis, Bernard (1990). Race and Slavery in the Middle East, Oxford: Oxford University Press, pp. 56-7.

${ }^{540}$ See Idris, Amir Hassen (2001). Sudan's Civil War, Slavery, Race and Formational Identities, New York: The Edwin Mellen Press, pp. 12-13. Jok, Madut Jok (2002). War and Slavery in Sudan, Philadelphia: University of Pennsylvania, pp. 6, 63 .

${ }^{541}$ Ewald, op. cit., pp. 48, 56.
} 
psychological systematic mistreatments inflicted on her by a Muslim Arab slaver who used to call her "abid" (slave). ${ }^{542}$ Another question asked was: "How conversion from one religion to another religion in Sudan is conducted; do you encounter an obstruction on the process and have you ever felt that there has been an interference of your ethnic customs, cultures and traditions to your religion, if yes, please explain?" Some Muslim students who answered this question claim that Muslim Arabs in power endeavour to convert the inhabitants of Sudan into the fold of Islam in order to build the umma. However, this endeavour manifests contradictions by constructing opposing categories of strangers and non-strangers, and of enemies and non-enemies in one religion, Islam. The students present their claims as: "We the Fur, we thought that Islam has ... cut the racial category of Arabs and Africans and we are people of one faith, Islam. But the practices of the successive Arabs in power see us as foreigners in Islam. We are seen as a bunch of African Muslims used for making a political Muslim majority to threaten non-Muslim African minority in the South." 543 Another one states: "Islam is a good religion, since it creates brotherhood in faith, but activities of Muslim Arabs holding power in the country show to us that we are not their brothers in faith but big enemies of Darfur. They take us for political aims to make a big number of the population of the Muslims". ${ }^{544}$ Someone else, comments: "Most of us in Nuba Mountains know that Islam is a religion of God where we are all equal. This is contrary to the practice of the regime of al-Bashir. It divides us into good Arab Muslims in the North and the (sic) stranger Muslims in Nuba Mountains. Under this classification, we endured the Jihad of the government against our region in 1992". 545 Finally, a Beja student argues that in my home town, Port Sudan, when a Muslim Beja says he wants a high position in the Port, then he would be sent to work in a less privileged position and a Muslim Arab would take the highest position. This is not Islam which preaches justice and equality; it is a unique Islam of the Arabs in Khartoum. ${ }^{546}$ According to Bauman modernity regulates, and classifies circumstances. It has given us a society that organises itself and strives to regulate institutions, laws and moral codes and at the same time, it unfolds contradictions, since it classifies people into normal versus abnormal and barbarises other

\footnotetext{
542 See Nazer, Mende and Lewis, Damien (2004). Slave, the True Story of Girl's Lost Childhood and Her Fight for Survival, Helsinki: Otavan Kirjapaino Oy, pp. 12, 26, 46.

${ }_{543}$ Mahjoub Muhammad, Fur, University of Khartoum.

${ }^{544}$ Ali el-Nur, a Zagahwa, University of Juba.

${ }^{545}$ Musa Jalal, a Muslim Nuba, University of Juba.

${ }^{546}$ Khalid Muhammed, a Muslim Beja, University of Khartoum. Omer Hussien a Fur, University of Juba "A good position in every office in Darfur is always given to a Muslim Arab and, if a Muslim Fur, Zagahwa or Massaliet asks, nobody cares".
} 
civilisations. It dehumanises human beings of the other groups and makes them seem foreign and without reason. ${ }^{547}$

Islam in Sudan has become a source of forming political associations and building racial entities among the Muslims. Three scholars observe this dilemma among the Muslims of the Northern Sudan Region. First, Hassan notes that the pastoralist Arab tribes of the Habbaniyya, the Beni Hussain, the Zeidiyya, the Beni Halba, the Djawama, the Reizegat and the Mahariyya and many others, together with Muslim Jellaba (Arab merchants and Arab government officials) residing in Darfur converged together in the middle of 1990 and organised themselves into an exclusive organisation, Arab Congregation. The non-Arab ethnic groups in Darfur, the Fur, the Zagahwa, the Massaliet, the Meidoub, the Berti, the Tama, the Tunjur and others had organised themselves earlier in the middle of the 1960s, into a political body Darfur Development Front (DDF). ${ }^{548}$ Second, Iyob and Khadiagala observe that the Islamic slogan that was proclaimed in Northern Sudan was a source in building unified Sudan, but has now been diminished. The ruling Arab group in power has widened the ethnicisation of Islam, while the indigenous ethnic Darfurians experience discrimination. In this perspective, Afro-Muslims of Darfur have lost the feeling of being in the umma as they have found themselves excluded from the political Islamic sphere. Muslim Arabs in power stress Arabness against the Muslims that attempt to hold on their African roots leading to the current war between the janjaweed, an armed militia of Muslim Arabs, and the indigenous Muslims of Darfur rebels. Muslim non-Arab groups in Darfur have rejected what they call "Arab segregation" ${ }^{549}$ and commenced to repulse the janjaweed militarily. ${ }^{550}$

The ethnicisation of violence between the indigenous Muslim people of Darfur and the janjaweed who receive arms from the government symbolises institutionalised racism and such racial practices appear also within the institutions of the capital of Sudan, Khartoum. For instance, the faction of the Darfurian rebels, the SLM composed mostly of ethnic Zagahwa and few from other African tribes, under the leadership of Minni Arcua Minnawi signed a 'Peace Agreement' with the Government of Sudan in Abuja in May 2006. After this peace, Minnawi was appointed as a Senior Presidential Assistant of Sudan and the Head of the 'Transitional Governments of Darfur States' (TGOD). Minnawi lives in Khartoum with his guards who come mainly from Darfur. Some of these guards

\footnotetext{
${ }^{547}$ Bauman (1991), op. cit., p 14.

${ }^{548}$ Hassan (2007), op. cit., p. 21.

${ }^{549}$ Iyob and Khadiagala, op. cit., p. 136.

${ }^{550}$ Ibid.
} 
live in a rented house in Omdurman, the second largest city within the capital. On 24 March 2007, clashes occurred in Omdurman between a Zagahwa guard and an ethnic Muslim Arab resident of Omdurman. The police accused the guards of disorganisation and provided them an ultimatum to hand over some of their members for accountability, but the latter refused. ${ }^{551}$

In reaction, a force of armed Muslim Arab police with tanks attacked the residential house of some of the guards. Eight guards were killed and part of the house was devastated. Four guards were burnt to death inside a car. ${ }^{552}$ After this fatal incident Minnawi held a Press Conference and described the event as a pre-organised massacre by the ruling Muslim Arab party, the NCP, against the Muslims of non-Arab people emerging from Darfur. Minnawi argued "The house was for my guards and handicaps and I want to know the reason of massacre". ${ }^{53}$ The Police Deputy Chief, Muhammad Naguib el-Taib explained that the government had acted in that way because the Darfurians group refused to hand over a member involved in the earlier incident in Omdurman. ${ }^{554}$

The response by el-Taib who refused to lament the deaths and emphasised the legitimacy of the killing of the guards creates more suspicions towards the impartiality of the police. According to Collins, after the, NIF seized power in Sudan new recruitment standards were created for all national institutions, under the basis of religious Islamic orthodoxy. Muslims and non-Muslims in police who tended to disregard radical Islamic ideology were sacked in the name of what the NIF calls dismissal for the 'general interest' in the state. New officers mainly from those Muslim Arabs who supported strict Islamic system were installed. ${ }^{555}$

Tayyib Khamis, a spokesman for the eight killed men argued that the police attack was made in order to legitimate a declaration of war against the indigenous non-Arab people of Darfur and that

\footnotetext{
${ }^{551}$ Darfur Peace Agreement (2006, May). Darfur Peace Agreement, Abuja. The agreement articulates that soldiers of the SLA are accountable to their leaderships.

552 Sudani (2007, March 25). "Omdurman Tashad Istibaakaat Damyia bean el Shurtha wa el Harka Minawi, Omdurman Witnesses Clashes between the Police and the Movement of Minawi”, Arabic Newspaper, Sudani, No. 491, p. 1. The government of Sudan has killed ethnic Darfurians in Omdurman, where those killed included Abu Baker Ahmed, Hafez Ibrahim Muhammad Abdel Shafia, Al-Nur Adam Abdel Shafia and Abu Baker, known with the sure name Jangel, Muhammad Yacoub Hassan, A’amar Jabriel Bakheit, Sharief Wed Dernejig and Osman Ibrahim Suleiman.

${ }^{553}$ Shreq al-Awsat (2007, March 25). "Battle in Omdurman between the SLA and the Government Police", Shreq alAwsad English Newspaper Version No. 10335, p. 1.

${ }^{554}$ Sudani (2007, March 25). “Omdurman Tashad Istibaakaat Damyia bean el-Shurtha wa el-Harka Minnawi, Omdurman Witnesses Clashes between Police and Movement of Minnawi, Sudani, Arabic Newspaper No., 494 p. 1 ${ }^{555}$ Collins, Robert O (1999). "Africans, Arabs, and Islamists: From the Conference Tables to Battlefields in the Sudan, African Studies Review, the African Studies Association, Vol. 42, No., 2, p. 107.
} 
they were "ready to reply with the same method they have used", ${ }^{556}$ Subsequent events substantiated this threat. Three days after the Omdurman incident, the Zagahwa unleashed deadly assaults against some Arabised ethnic groups of Darfur that support Khartoum at the village of Abu Dangle in the province of Sheeriyyia in Darfur. The local acting Chieftain Abdullah Hassan Adam reported that Zagahwa forces loyal to Minni Arcua Minnawi kidnapped six men of Bergid ethnic group on 27 March 2007 and might have killed them as a vengeance to the killing of Zagahwa in Omdurman. 557

Why in Sudan is Islam emphasised in politics as an inclusive model for all the believers, and at the same time, some political actions seem to reflect ethnic race in social and political hierarchies among Muslims themselves? This question has been studied at the 'Institute of Peace Project' in the United States. David Little notes that while different ethnic groups in Sudan were converted from their traditional religion to Islam, yet this did not remove conflicts of national identity. What is precisely the connection between religion and ethnicity in nationalism in Sudan? ${ }^{558}$

Interviewed Muslim students provide conflicting reasons for the connection between Islam, ethnicity and nationalism. Some of them provide answers which are based on the Islamic religious ideological doctrine that views all Muslims as an umma, a nation in faith. One Muslim student explains that the Prophet Muhammad dysfunctionalized ethnic kinship and Muslims became all brothers and sisters in Islam. For this reason, Islam is the best system in Sudan. ${ }^{559}$ Nevertheless, in the view of a Nuba student: "The constructing Arab rulers in Sudan exclude the South and use Islam as a unifying factor for the rest of other regions for the purpose of building a majority that faces the Christian and Animists of the South". ${ }^{560}$ In the opinion of the student Adila Khadier this model of constructing the umma could be the best only, if the Arabs in power practice Islam in its authentic way that considers equality of all Muslims, irrespective of ethnic and race. ${ }^{561}$ For Muhammad Abel Wahab: “Arab Muslims use Islam in double standards. First, they are minority and it is ... Islam which they adopt to raise their number to the status of majority and in distribution

\footnotetext{
${ }^{556}$ Reuters (2007, March 26). "Sudan Police, Darfur Former Rebels Clash 10 Dead”, Reuters http://news.scotsman.com/latest.cfm?id=463512007.

557 Sudani (2007, March 30). "Al-Berged Yatahamuun Kawaat Tab'ba le Minnawi Beiktithaf Sita Afraad al-Berged”, “Al-Bergid Allege Minnawi Forces of Having Kidnapped Six Persons of Them”. Arabic Newspaper, Sudani, No., 491. p. 2.

${ }^{558}$ Little, David (Summer, 1995). "Belief, Ethnicity and Nationalism”, Nationalism and Ethnic Studies, Vol. 1 No. 2 , pp. 284-301.

${ }_{559}$ Hatim Muhammed, Ja'aleen, Omdurman Ahlia University.

${ }^{560}$ Hamza Suliman, University of Khartoum.

${ }^{561}$ Adila Khadier, a Muslim Zagahwa, University of Khartoum.
} 
of jobs, Islam is put aside and Arabs in power favour Arab race in all national organs". 562 According to these students religion is used in Sudan as a way to create a political majority group. Some statistics claim that the Arabs represent only $31 \%$ of the population of Sudan and $69 \%$ is African. ${ }^{563}$ On the other hand, the number of Muslims is estimated as $70 \%$ of the population whereas only 25\% is Animist and 5\% Christians. Most of the latter live in the South. ${ }^{564}$

These ethnic and religious terminologies of majority and minority play an influential role in the functions of public institutions in Sudan. According to Simone, Islam is used as a cement to build a Northern Muslim majority and it has been developed as an ideology that unifies the diverse ethnic groups in the North as Muslims. In this sense, the Christians and Animists residing in the South are a minority and therefore less influential in political decision-making. ${ }^{565}$ This perspective that considers religion as a means of constructing a majority transforms Islam in Sudan into an ideological religion, rather than a faithful religion. There is a difference between the faithful and ideological religion. According to Nandy, distribution of things among the believers makes a distinction between religion as a pure faith and religion as an ideology. When religion is held as a faith, it is located in the domain of everyday life, where every faithful person receives equal treatment from public institutions and serves them in turn. Other words, it is the whole body of believers who are involved without the distinction of majority and minority categories. Ideological religion establishes categories of racial discrimination among the believers. ${ }^{566}$

Distribution of wealth and power in Sudanese institutions shifts religion to the status of an ideology. Under this religious ideology, an equality based on the Islamic faith among the Muslims vanishes and an Islamic ideology based on ethnic Arab background supersedes. Two sources claim this form of structure in the institutions of the Islamic Sudan. First, Senior Presidential Advisor, Minni Minawai Arcua defines the NCP as "a racial organisation... and that would lead to the separation of the South from Northern Sudan". ${ }^{567}$ Second, an anonymous book The Black Book; Imbalance of Power in Sudan Seekers of Truth and Justice argues that excluding South Sudan

\footnotetext{
${ }^{562}$ Muhammad Abdel Wahab a Fur, University of Khartoum.

${ }^{563}$ Simone, op. cit., p. 198.

${ }^{564}$ Lesch, op. cit., p. 20.

565 Simone, op. cit., p. 198.

${ }^{566}$ Nandy, Ashis (1997). Creating Nationality the Ramjanmabhumi Movement and Fear of the Self, Oxford: Oxford University Press, p. 5.

${ }^{567}$ Sudan Nile (2010, January 7). "Minnawi Itifakyyia al Salam Darfur Peace Agreement”, Arabic electronic Newspaper, Sudanile, http//www.sudanile.com/index.php?option=com-content\&view=articleie\&id=9477:2010-01-0706-16-43\&catide=42:2008-05.
} 
which is in a state of war against the Islamic Arab North, all national resources are confined for the development of the northern Arab territory and only a small part of this development goes to the east and centre. The entire western region of Darfur has no single development project. Oil refineries in the west are all defined as national projects, but in practice Arabs from Khartoum control employments in these refineries. The local indigenous Muslims are confined to manual jobs while all higher positions at these refineries are given to the Arabs brought from the north. For instance, drivers and officers of the security personnel are selected from among people with Arab background. The selectors are themselves Arabs and favour their fellow Arabs barring non-Arab Muslims from owning wealth and power. ${ }^{568}$

In the opinion of a Nuba Muslim student, the structure that favours Arabs in dealings with other Muslims in Sudan has been a consistent political model of Sudan from its foundation to present day. The student argues: "The Arab culture sees the Black Muslims as slaves, because they associate religion, Islam to their Arab culture and behaviour. For this reason, the ruling Arab systems which have ruled Sudan, including the present one are unsuccessful, because their aristocratic and theocratic power that builds intertwines Islam with Arab culture. In their good minds, they view the African Muslims who are non-Arab Muslims as inferiors and assume themselves to be superior to the Muslim Africans". ${ }^{569}$ A Muslim Arab student from the Hassaniya of the Central Region of ElGezira does not regard the linking of Arab culture with religion as a manifestation of superiority over non-Arab Muslims in Sudan. For him, Quran was revealed in Arabic, therefore, Arabic is a holy language of the Quran and this justifies the national identity of Sudan to be defined in a national constitution as an Arab Islamic state. History of Islam justifies that Islam is linked with Arabic. Hence, there is no obstacle to connecting religion with Arabic constitutionally in the country. A Muslim understands that there is a connection between Islam and Arabic. Essential Quran was sent to mankind in Arabic; therefore, it is a holy and blessed tongue. ${ }^{570}$ This assertion is opposed by a Fur Muslim student who argues that a good system takes into consideration social structures as realities. In Sudan, social institutions are culturally diverse, but some Muslim Arabs connect Islam with Arab culture, under the claim that God gave Quran to the Prophet and ordered him to recite it in Arabic. He states: "It is true; the religion was delivered to the Prophet in Arabic,

\footnotetext{
${ }^{568}$ Seekers of Truth and Justice, op. cit., p. 5.

${ }_{570}$ Abdel Bagi Muhammed, University of Khartoum.

${ }^{570}$ Abu Hamza Jalil, University of Khartoum.
} 
but in my opinion, it was, because the Prophet Muhammad understood only Arabic and had nothing to do with the religion". 571

The association of Arab cultural identity with religion stirs a conflict between some Muslim Arab students and some Muslim African students. Some indigenous Muslim students from Darfur explained their rejection of the association of Islam with Arabic. They claimed that the first revelation of God's contacts with the Prophet Muhammad through the heavenly Messenger, Jabra'il was void with any instruction to the Prophet Muhammad to sanctify Arabic. ${ }^{572}$ For them, any language is appropriate for the Quran and has nothing to do with Arab as a race. ${ }^{573}$ Another one concludes: "If the Prophet Muhammad had been a Dinka man and God had chosen him to convey His message of redemption to mankind, he would have communicated in the Dinka language. The Holy Quran would have descended down in Dinka, which Muhammad would have understood, but these Arabs want to own the religion of God". 574

Furthermore, some Muslim Arabs at the University of Khartoum object this opinion that attempts to de-link Arabic from Islam in their responses to the question: how do you want national identity of the diverse regions to be defined in a national constitution of Sudan...? Some of them propose that any constitution in Sudan should take into account the Muslim majority and mention the special position of Arabic and Islam. ${ }^{575}$ One of them concludes: "Arabic has no comparison with other languages; it is a divine and special language that comes from a nation worthy to God, because the Prophet said, 'I am an Arab' without 'a' 'rabb' means Lord". 576

\subsection{Islamic-Arabic and skin colour}

Learning Arabic as a religious language has become a viable claim in Africa. For instance, Leblanc says some African Muslims are convinced that understanding Holy Quran in strict methodological

\footnotetext{
${ }^{571}$ Ahmed Gurun Darfur, University of Juba.

${ }^{572}$ Fatima al-Din Ahmed, a Fur, University of Khartoum states "The Prophet Muhammad did not say that take Arabic as a holy language, instead the Quran. "Arabic has no holy message to offer; it was just the language of the Arabian environment".

${ }^{573}$ Abdel Rahman Hassan, a Muslim Nuba, University of Khartoum states: “Any language is holy, so the Quran could be sent out in any language. African tongues articulate African languages, so the Quran could be in Fur, Massaliet, Dinka and Nuer languages".

${ }^{574}$ Awadia Khalil, a Nuba, University of Khartoum.

${ }^{575}$ Hashim Abdellah: "Everywhere in the world; nations take into consideration the majority. Muslim Arabs are the majority here, so a constitution must look into this structure". If we talk of democracy, then the Muslims are the majority, so a constitution must take into account this sense, rather than pleasing the minority Christians and pagans".

${ }^{576}$ Salim Muhammad, a Misseiriyyia Arab, Southern Darfur region, University of Juba.
} 
teaching requires Muslims to pay attention to Arabic as the original language of the Quran. ${ }^{577}$ This view of paying 'attention' to Arabic conforms to the argument of a Muslim student who states that: "An authentic Muslim must admit a constitution that embodies Arab culture. The Quran means read something written in Arabic neither in Nubia, Fur nor in Dinka tongues in Sudan. A Muslim who reads Quran in Arabic is transformed and assimilated into a new Islamic Arab race." 578 A Muslim from the Zagahwa ethnic group from Darfur presents his opposition to the linking of Islam with the Arab language. In his opinion, a Muslim comprehends the Quran as a derivative word from Arabic, recited or read. A Muslim is someone who submits himself to God and not to Arabic as a language. ${ }^{579}$ Another student Nimeiri Sabur argues that every religion is fed by its traditions; Islam is not special from other religions. It takes Arabic language as a source of divine message. ${ }^{580}$ Furthermore, Muhammed Sultan argues that Arabic is the only language which a Muslim can ultimately recite al-Fatiha. Reading it in other languages distorts its divine and sacred essence. ${ }^{581}$

The views of these students are emphasized here in order to establish the existing point of departure among the Muslims of Sudan. According to Lesch, Sadiq Al-Mahdi, Head of the Islamic sect, Ansaar and Former Premier of Sudan from the Umma Party insists on the association of Islam and Arab culture. For him, both Arab culture and Islam are dominant features of the Sudanese people, which provide a prestigious status for their nation-state, Sudan. ${ }^{582}$ One of the students provides an answer that reflects the position of Sadiq Al-Mahdi as he argues that Arabic and Islam are interconnected entities. Arabs came to Sudan with a civilised religion as a redemptive power to the former Black slaves and freed them. Now in Sudan each one is free and identified as 'Brown' in documents. Before, the Black people were not free in Sudan, but Arab Muslims freed them by changing their status into 'Brown'. Arabic is a tongue of a prestigious nation with the true faith. ${ }^{583}$

Generally, power in Sudan has constructed the colour of the Arab skin as 'green' and contextualised it as a colour of pride as opposed to the 'black' colour which it considers as a colour for slaves. Such racial category based on colour neglects the fact that most of those who claim Arab identity carry in their veins African blood and that Blacks living in the South have never been

\footnotetext{
${ }^{577}$ Leblanc, Marie Nathale (1999, October). "The Production of Islamic Identities through Knowledge Claims in Bouke Cote d'Iviore, African Affairs, the Journal of the Royal African Society, Vol. 98, No. 393, p. 485.

${ }^{578}$ Muhammad Dafala, a Halawain Arab, Omdurman Ahlia University.

${ }^{579}$ Walid Abdullah, Omdurman Ahlia University.

${ }^{580}$ Nimeiri Sabur, Omdurman Ahlia University.

${ }^{581}$ Kababish Arab, Northern Kordofan, University of Khartoum.

${ }^{582}$ Lesch, op. cit., p. 55.

${ }^{583}$ Imad Salim a Shukuriyyia, University of Khartoum.
} 
slaves. Francis Mading Deng wrote at the foreword of the book War and Faith in Sudan that the Northern Sudan Arabs call their colour as 'green' to express a pride and 'blue' as a polite version of their black colour, which is constructed to represent the identity of a slave. The Arabs use it as a result of suffering with an inferiority complex. Yet, they forget that their veins contain blood from the black people since many of them are children of Black women. ${ }^{584}$

\subsection{Brown and black skin colours}

Questionnaires and public discussions with students provide a continuity of conflicting definitions of identity in Sudan. A Muslim student argues that general observation of the people in Sudan gives an image that we are all the population is black. The physical features of the most people appear black, so there are no pure Arabs here as they are in the Arabian Peninsula. ${ }^{585}$

The issue of the colour 'black' is problematic in Sudan. Some students say that their physical identity of being 'blacks' cannot be used in the national institutions of the state. For instance, an official document for the establishment of nationality provides a space where an applicant is requested to describe the colour of his or her face. An applicant that chooses to describe it as 'black' is considered to deviate from the system and to make an incorrect identification. One student explains that: "I had wanted to get a passport to travel with my sister to Egypt. I found a question that urges the applicant to describe the face, so I wrote 'black'. It was not accepted, so in my passport, my face is described as brown". ${ }^{586}$ Salwa Osman explains that "One time, I filled out the application for the passport, after I got admitted to the University of Khartoum. I described my face as 'black'; the police lady in control rejected it and wrote her own description that I was brown". 587 Another student concludes that it is incumbent upon a police officer in charge of the forms of nationality to remove the 'black' description and insert asmer (brown). ${ }^{588}$

Thus, brown colour appears to be a colour in national documents for the skin colour. As another student states: "If you describe yourself in our national state's document as 'black', the police would refuse and insert a preferred colour, 'brown'. So in Sudan, we are all 'Browns' rather than 'Black' people". ${ }^{89}$ In this sense, every 'Black' person is conceptually characterised as 'Brown'.

\footnotetext{
${ }^{584}$ Meyer, op. cit., p. xi.

${ }^{585}$ Saleem Azhari, University of Khartoum, Nuba Mountains.

${ }^{586}$ Kuot Atem Dhal, a Dinka, University of Juba.

${ }^{587}$ Gada Osman, a Nuba Muslim, University of Khartoum.

${ }^{588}$ Amel Yel Akol, a Dinka, University of Juba.

${ }^{589}$ Mayen Mamier, a Dinka, University of Juba.
} 
This is reflected in the students' answers to the research question that states: "Have you ever experienced any form of discrimination in any region of Sudan, if so, please explain?" Most Black Christians, Muslims and Animists complain about the rejection of their real colour in the official documents of the state. For example, a Dinka Christian Animist gives a testimony of her experience with the National Interior Ministry that offers documents of nationality and passports. She states: "When I got admitted to the university I wanted to travel ... I went to fill the form at the National Interior Ministry in Khartoum. During the filling of the form, I found a blank space, which demanded the description of the face. I wrote there the colour of my face, 'black', but the police in charge urged me to change it to brown. I refused, but she cancelled the 'black' and wrote 'brown' there. ${ }^{590}$ When the author asked to explain what she thought about the action of the police the student responded: "These Arab Muslims they practice prejudice against the black colour. It was for this reason; the police woman thought that she ... had acted in a good faith. It was a removal of what they wrongly assume ... Islam had freed us from paganism and slavery, so we are all equally 'brown'. In their concept here in Sudan; a free person is not 'black', even though she or he looks 'black", 591

The obligatory insertion of the 'brown' colour, instead of the 'black' colour in official documents indicates that power in Sudan seeks to construct identities in a way that suits its own purposes at the expense of the interest of the applicants. This practice in the Ministry of the Interior contradicts the view of the President Al-Bashir. According to him, "We are all Africans and we are all Blacks; our current conflicts and problems in Sudan are caused by the colonial powers American, Israeli and British. This alliance wants to come back to re-dominate the region". ${ }^{592}$ In reaction to the President's speech, a Dinka university student responded "For every Black soul in Sudan, we better have Israel, American and British as our colonisers. We are told to choose, just like you chose". 593

The definition made by the President in the international media to call the Sudanese people inclusively 'Blacks' could be interpreted in two ways. Perhaps he wanted to influence public opinion of the Black Muslim African Americans as he states "I was using the address to call on the

\footnotetext{
${ }^{590}$ Akon Wol Chol, Southern Sudan, University of Juba.

591 Akon Wol Chol.

${ }^{592}$ Satellite Live on the National Television of Sudan on Saturday 24.2.2007. President of Sudan, Field Marshal Omer Hassan Al-Bashir Addresses the Muslim African Americans, Nation of Islam under Louis Farrakhan in Detroit, USA from Khartoum.

${ }^{593}$ K. Thuc, University of Juba.
} 
mass media and American public to learn the truth about my country." ${ }^{, 594}$ Second, the President might have wanted to express his physical appearance in comparison to the Black Muslim African Americans, who are often lighter than he is Akbar Muhammad, a representative of the American Islamic organisation Nation of Islam pointed at him during the interview declaring "he is darker than me". ${ }^{595}$ Simone says that some of the Islamic movements in Sudan, including the NIF have reached to the conclusion that the establishment of national coherency could be achieved by intensifying assimilations of the Christians and Animists population in the South into the Islamic culture. ${ }^{596}$

${ }^{594}$ Satellite Live on the National Television of Sudan on Saturday 24.2.2007. President of Sudan, Field Marshal Omer Hassan el-Bashir addresses the Muslim African Americans, Nation of Islam under Louis Farrakhan in Detroit, USA from Khartoum.

595 Ibid.

${ }^{596}$ Simone, op. cit., p. 110. 


\section{ASSIMILATION}

Most Christian Animist students from the South believe that there is no suitable constitution in Sudan which would be a convergent body representing all the heterogeneous Muslim Arabs with the Christians and the Animists of the South. They argue that British colonisers and Muslim Arabs overshadowed this extreme and diverse heterogeneity of religions and customs between the two populations and arbitrary made them as one territorial nation. ${ }^{597}$ Some explain that during the colonial period Great Britain separated the South from the North, because of the opposing religious cultures. The past separation was a significant precedent that no constitution could bind them together. ${ }^{598}$ Muslim Arabs of the North want the state to be Islamic and Arabic constitutionally, while the Christians and the Animists from the South want the criminal and civil penal codes in the country to be derived from Christian secular laws and African customs. ${ }^{599}$

The students' claim of the past territorial separation is a fact of history. For twenty-five years, from 1922 until June 1947, British colonisers ruled the current Sudan officially as two different territories. In 1926, two British colonial officials in Sudan, Civil Secretary Harold A. McMichael and the Secretary of Finance, Sir George Schuster acknowledged the existence of wide cultural differences and introduced measures to the British Government to administer the population of the South independently. The intention was to groom the South towards its culturally similar zones of East Africa, particularly Uganda and British East Africa (modern Kenya). At that time, the Northern political institutions such as the Graduate Congress and Advisory Council of the Northern Sudan operated in the North independently in exclusion of the people of the South. ${ }^{600}$

The reunification of the Anglo-Egyptian Condominium of Sudan did not take into account the conflicting cultures of the two territories. Instead, it was made in accordance to the interests of Muslim Arabs of the North in coordination with the British Civil Secretary, James W Robertson.

\footnotetext{
${ }^{597}$ Lual Deng Ayom, a Dinka Christian Animist, Bahr el-Ghazal University. "People of the South and North were brought together by Chance".

${ }^{598}$ Dut Mou, a Jur Christian Animist, University of Bahr el-Ghazal: "British administrators knew that we had two different religions and ethnic identities. The North is Arabised and Muslim and the South is African and Christian Animist. And for this, they first set us apart and later reconnected the territories as one. So, there is no constitution that could make these contradictory people to be one".

${ }^{599}$ John Manut, a Christian Animist: "We the people of the South ask for the secular constitution to be adopted in Sudan". Turabi Hamda, a Muslim Arab, University of Khartoum: "We in the Islamic North need an Islamic constitution in Sudan".

${ }^{600}$ Simone, op. cit., p. 47.
} 
According to Johnson the re-unification was influenced by Ismael Al-Azhari, a leading Muslim Arab nationalist at that time. During the arrangements made for the de-colonisation of Sudan, the British Administration set up a system called Legislative Assembly in the North as a step for a post independence national assembly in exclusion of the South. In 1946, al-Azhari raised the question of the South at the political meeting of the Graduate Congress. According to him, the South was an economic backbone for the North and there was a need to re-attach it to the Northern territory. He made a motion raising this issue to the British Administrators in charge of Sudan. ${ }^{601}$ One year later, Sir James W Robertson British Civil Secretary for Sudan organised a conference under his Chairmanship from 12-13 June 1947 in the town of Juba, South Sudan. The representation in this conference was not proportional in terms of number and educational backgrounds. Seventeen men including clergies, administrators, a police sergeant and ten illiterate traditional Chiefs represented the Christians and the Animists of the South. And five men, some of them with advanced educational degrees represented the Muslim Arab North. ${ }^{602}$ The agenda for the conference presented to these representatives was whether they consider the South to be essentially one with the North or whether it should remain an independent sovereign territory. ${ }^{603}$

The Chiefs were illiterate. ${ }^{604}$ Yet, they were capable of communicating their views about their culture over this question. During the colonial period, the role of the African Chiefs was not limited to the traditional institutions, but also extended to include political institutions. They played roles of settling issues falling within their indigenous national structures and influencing political issues in the colonial government. ${ }^{605}$ For Robertson, it was important to fulfil the social discourse "nothing about us without us." ${ }^{606}$ Thus, he invited the Southern Sudan's Chiefs to the conference as decisionmakers to provide their views on the issue of the two territorial identities. The Chiefs represented the will of their communities. Yet, the representatives of the Islamic Arab North and Robertson

\footnotetext{
${ }^{601}$ Johnson (2003), op. cit., pp. 24-25.

${ }^{602}$ Said, op. cit., p. 46. Chiefs: Cier Rehan, Giir Thiik Riny, Hassan Fertak, Ukuma Bazin, James Tambura, Lolik Lado, Lappanya, Tete and Lueth Ajak, and the literates Sergeant Major Police, Majok Philomon Majok, Fr. Guido Akou, Administrator Clement Mboro, Pastor Andrea Apaya, Edward Adhok, Both Diu and Ciricio Iro. Intellectuals from the North, Habib Abdulla (PhD), Judge Mohammad Saleh Al-Shingethi, Ibrahim Al-Badri, Sheikh Surur Mohamed Ramli, Hassen Ahmed Osman, Kayangi Ababa.

${ }^{603}$ Juba Conference (1947 June 12-13) EP/SCR/1.A.5/1 Juba, 21 June 1947, Deputy Governor, Bahr el Ghazal/ Area, Wau, p. 12.

${ }^{604}$ Said, op. cit., p. 46. Chiefs were mostly well informed about Sudan culture and politics, even though they were illiterates.

${ }^{605}$ Fallers, LIoyd A (1973). Inequality Social Stratification Reconsidered, Chicago: The University of Chicago Press, p. 38.

${ }^{606}$ Steinberg, Donald (2007, December 14). "A Seat at the Table: the Role of Displaced Persons in Peace Talks and Rebuilding", a Paper Presented at the US, Institute of Peace, Washington DC, p. 2.
} 
disdained their concerns and views over the proposed bill on the re-unification. Consider the statements of three Chiefs. First, Chief Cier Rehan from Northern Gogrial of Tuic Dinka rejected the re-unification. He argued that the South was distinct culturally as Christian and Animist and the North was Islamic and Arabised and according to him, this cultural contradiction impeded reunification. ${ }^{607}$ Second, Chief Hassan Fertak, from the Kerish ethnic group of Raja at Western Bahr el-Ghazal, who was himself a Muslim, ${ }^{608}$ states "The tribes of the North have much more common culture, Islam and they could be one, but we in the South have our different culture which is not common with them, so there is no basis for becoming one". 609 Third, Chief Ukuma Bazin presented the question: "What are the guarantees for the safeguard of our customs; if the population of the South were to re-unite with the people of Muslim Arabs of the North as one people?" 610

Practically, these principal concerns and worries of the Chiefs towards the re-unification were totally ignored. On the second day of the conference, Robertson summed up the discussions by reading out instructively the resolutions of the re-unification of the territories. According to him, the people of South Sudan wanted a unified Sudan with the people of the North and to participate in the proposed Legislative Assembly in Khartoum. Also, the people of the South were not sufficiently advanced to participate immediately in such assembly. Therefore, it was important to hasten the establishment and development of Local Government in the South. Finally, the Southerners should at first attend the Legislative Assembly only as observers. ${ }^{611}$

The research theme of this study is not to research on the history of Sudan, yet history becomes important, because it is a continuity of the past and present. Thus, the views of Christian, Muslim and Animist students towards the historical amalgamated conflicting cultural identities of present Sudan are of the great significance. Their suggestions and thoughts as citizens and future leaders of the country contribute in addressing this long conflict of identity. Conflicting observations in regard to the definition of identity in Sudan can be found in students' answers to the question: "How do you want national identity of these regions to be defined in a national constitution of Sudan and under what system suits Sudan best and why do you think so?" Some Muslim Arab students urge

\footnotetext{
${ }^{607}$ Juba Conference (1947 June 12-13), EP/SCR/1.A.5/1 Juba, 21 June 1947, Deputy Governor, Bahr el Ghazal/ Area, Wau, p. 12.

${ }^{608}$ Said, op. cit., p. 46. Chief Hassan Fertak, a Muslim from the Western Bahr el-Ghazal.

${ }^{609}$ Juba Conference (1947 June 12-13), EP/SCR/1.A.5/1 Juba, 21 June 1947, Deputy Governor, Bahr el Ghazal/ Area, Wau, p. 12.

${ }^{610}$ Ibid.

${ }^{611}$ Op. cit., p. 13.
} 
the application of Sharia in all public institutions of Sudan as the will of the majority. They argue that: "We are the majority in population as Arabised Muslims and it is an important issue for the political masses in the country to consider it in a national constitution. Our identity as the majority is embedded in Islamic and Arabic culture." ${ }^{612}$ Another states: "God in the Holy Quran instructs the Muslims that those who do not judge in accordance to Sharia as God given law, then, they are infidels, oppressors and corrupts (Surra Maida 44-45, 47)". 613 It would be a challenging step for any Muslim political leader to undermine such views and produce a constitution that reflects secularism. ${ }^{614}$ According to one Arab Muslim student, Islam is the only religion which provides a chance of homogenising heterogeneous cultural identities peacefully into "a faithful Muslims nation without problems, but enemies of Islam refuse to give it a chance". 615

On the other side, some students identify themselves as Muslims and yet, they reject the application of a constitution that derives its civil and criminal codes from Sharia, where hudud is applied with punishments like amputation of the limbs for a theft. One of them states: "I am in particular for the constitutional system that is empty of religious Islamic laws, because it is capable to sustain the religious diversity of Sudan." 616 Another Muslim in support to this view argues that: “In Muslim's Sudan, hospitals inflict bodily harm leading to the handicap of the Sudanese citizens. In these hospitals, medical doctors chop limbs of citizens and in turn, the amputated citizens become unwanted handicaps. This practice is contrary to the neighbouring Muslim majority country of Egypt. In Cairo, the capital city of Egypt, human limbs could encounter tragic accidents leading to their fracture on public traffics, yet hospitals receive them for treatment". 617

The author observes that Sharia is not widely embraced among the interviewed students except for the fear of reaction of the radical Islamic Government with allegations of apostasy that may victimise any opponent to its application. Several medical students claim that the majority of surgeons amputate human limbs, because they are forced to do so by the authorities, but they abhor the nature of this practice, since it contradicts their moral ethic of the medical profession in treating

\footnotetext{
${ }^{612}$ Saeed Ahmed Mohammad, a Ja'aleen Muslim Arab, University of Khartoum.

${ }^{613}$ Ali Muhammad Wed Fadil, Shoukri Arab, University of Khartoum.

${ }^{614}$ Habib Abdullah Ibrahim, Rezeigat of Southern Darfur Arab, Omdurman Ahlia University: "Islam cannot to be abandoned by any Muslim politician and forced the Muslims into a wild constitution of secular customs".

${ }^{615}$ Ibrahim Sid Ahmed, Omdurman Ahlia University..

${ }^{616}$ Aziza Hashim a Mahas of Nubia, University of Khartoum. Aisha Haruon, a Muslim Fur says: "secularism helps in maintenance of individualism in a united Sudan".

${ }^{617}$ M Ahmed, a Muslim Hawazama Arab, University of Khartoum.
} 
human beings. ${ }^{618}$ According to An'Naim, in Sudan Sharia is defined constitutionally as a divine law and such definition prohibits all attempts to criticise or discuss it in a way of offering alternative legal views to it. Power in the state charges its critics with apostasy, which is a crime punishable by death, under section (126) of 1991, Penal Code of Sudan. ${ }^{619}$

Some Muslim students who call for Sharia to remain a source of legislation constantly threaten the opposition students who call for the resumption of the non-Islamic constitution as murtadeen (apostates). They argue that any constitution that ignores the majority Muslim Arab interest in Sudan must be declared as a constitution of murtadeen. ${ }^{620}$ The rejection of Sharia by various opposition forces is equally an invitation of Jihad to fight them as apostates. ${ }^{621}$ Some Muslim students state: "Islamic constitution makes us close to God" 622 , because "Sharia is a derivative law from the Quran". 623

Such conflicting political views between the majority Muslim Arabs, or Arabised Muslims, and the assumed minority of the apostate Muslims and non-Muslims in the South becomes an obstruction in reaching a consensus on the unified constitutional legal code. The contradictory religions, customs and cultures make it difficult to forge an inclusive constitution that would be acceptable to the people of different faiths and cultures in Sudan. In the social view, power and wealth in a state determines the constitutional identity of a people in a country. It is the interest group in control of power and wealth in national institutions that has the upper hand in dictating the terms of national identity. Its wealth is an instrumental tool that protects its power and both are used for the construction of political aims. ${ }^{624}$ According to Lesch, ethnic Muslim Arabs in Sudan have monopolised power and wealth in all organs of public institutions of the state. In this way, their ethnic and cultural dimensions become the derivative sources for determining the operations of the institutions in the country. ${ }^{625}$

In the opinions of some Muslim students from Darfur: "Muslim Arab politicians in the North exercise a policy of exclusion of South Sudan from the rest of the regions, since the foundation of

\footnotetext{
${ }^{618}$ Saleh Muhammad, University of Khartoum, Awadia Silman, University of Khartoum, Muhammad Khdir.

${ }^{619}$ An'Naim, Abdullahi Ahmed (Summer 203). "Re-affirming Secularism for Islamic Societies", New Perspective Quarterly, Vol. 7, p. 1-2.

${ }^{620}$ Maburouk Ahmed, a Muslim Hawazama, University of Khartoum.

${ }^{621}$ Najela Saleh, Shaiqqiyyia Arab Muslim, University of Khartoum.

${ }^{622}$ Munem Samir Ali, a Muslim Hawawir Arab, University of Khartoum.

${ }^{623}$ Sadiq Yasar, a Ja'alei Muslim Arab, University of Khartoum.

${ }^{624}$ Robertson, Ian (1987) ( $3^{\text {rd }}$ ed.). Sociology, New York: Worth Publishers, p. 269.

${ }^{625}$ Lesch, op. cit., p. 47.
} 
their ethnic religious and political movement, the Graduate Congress." ${ }^{626}$; "This elite group defines our national identity constitutionally as Islamic and Arabic." 627 "We are not Arabs, but some of us are African Muslims, African Animists, African traditionalists and African Christians." 628 "When we say, Sudan is composed of different religions, cultures and customs, Muslim Arabs in control of power and wealth use these means to dictate Arabism on the non-Arabs in the country." ${ }^{629}$

These opinions of the students return us to the history of Sudan prior to its independence; in 1938, the intelligentsia from the North formed a Graduate Congress an association composed exclusively of Muslim Arabs. In 1942, this association raised the issue of nationalism of the people of Sudan to determine their territorial national identity. The group drafted a memo addressed and submitted to the British Civil Secretary Sir Douglas Newbold. In response, Newbold defined the memo as an act of an individual interest group that did not represent the whole country. During that time, Muslim Arabs were divided over the issue of independence without participation of the people of South Sudan. Ismail al-Azhari who became later the Prime Minister headed the group that demanded the annexation of Sudan to Egypt to become one territorial nation. His opinion received support from the Islamic religious sectarian group, al-Khatimyyia of Ali al-Mirghani. Some within the Congress opposed this opinion and sought support from Sayyid Abdel Rahman al-Mahdi who headed the Ansar Islamic sect in Sudan. ${ }^{630}$

Those responded and interviewed students, Muslims, Christians and Animists who identify themselves as non-Arabs claim that these political and Muslim sectarian associations inherited power and continued to pursue the policy of assimilation of the diverse cultures to the Islamic Arab culture. The students argue as: "Whenever I read the history of Sudan, I see it as dirty and misleading. It has been based on the assimilation of the non-Muslims and the non-Arabs to become Muslim Arabs in all walks of life." ${ }^{631}$ Since, the time of independence, two Muslim sectarian political parties, the Umma and the DUP have been striving to assimilate us to be Muslims and at the same time Arabs." 632 "These parties want the diverse cultures of the people in Sudan to be

\footnotetext{
${ }^{626}$ Abdel Naser Muhammad, a Fur, University of Khartoum.

${ }^{627}$ Salwa Zubeir Taj El-Din a Zagahwa, University of Khartoum.

${ }^{628}$ Saeed Zuheir, a Fur, University of Khartoum.

${ }^{629}$ Naji Hamed, a Massaliet, Omdurman Ahlia University states: "The Muslim Arabs control wealth and power and the non-Arabs are faced by poverty which makes them become submissive to the Arab Islamic identity in Sudan, but it is not really discussed openly".

${ }^{630}$ Johnson (2003), op. cit., p. 23.

${ }^{631}$ Muna Suleiman Muhammad, a Muslim Fur, Omdurman Ahlia University.

${ }^{632}$ Nahed Abdel Aziz, a Muslim Nuba, University of Khartoum.
} 
Islamic and Arabic throughout the time." 633 "Our representatives from the South rejected that constitution and we continue to reject it, until today." ${ }^{634}$ One Christian concludes: "People of the South want a pluralistic constitution; if not the solution is the separation of the Christian Animists of the South from the Islamic North and we become an independent neighbouring states, the Islamic North and Christian and Animist South." 635

Historically, the conflict of ideologies between the adherents of ethnic territorial national pluralism, who call for a secular constitution and the adherents of ethnic territorial nationalism, who advocate the Islamic law, Sharia dates back to September 1958. At that time, a panel of National Constitution Commission was formed ${ }^{636}$ Three members represented the South and forty-three the North. During their discussions, race and religion divided the commission. The forty-three Muslims drafted a constitution that defined Sudan as an Islamic Arab nation-state and recommended the adoption of that definition in the state's national constitution. Three members from the South interpreted the draft as a democratic Islamic ideological assimilation. They accused the Muslims of having legislated assimilation of ethnic and religious minorities and urged the adoption of a secular constitution. Yet, the majority finalised the draft of a constitution in its defined form Islamic and Arabic and presented it to the Parliament. During the parliamentarian debate, forty MPs representing the Christians and the Animists of the South withdrew from the session in protest of the majority attempt to impose a constitution that constituted Sharia a source of legal provisions and Arabic an official language in national institutions of the state. ${ }^{637}$

Critics describe a democratic majority system that disregards minorities' rights within a territorial state as tyrannical. Under such a democratic majority, protection of minorities' rights as distinctive groups is jeopardised. Cunningham explains in some democratic institutions, the majority may exert its interest at the expense of the minority on the provisional conception of democracy. Such a

\footnotetext{
${ }^{633}$ Adeng Mel, a Dinka Christian Animist, University of Juba.

${ }^{634}$ Rebecca Nyanluak, a Christian Dinka Animist, University of Upper Nile.

${ }^{635}$ Agoth Majut, a Dinka Christian Animist, University of Juba.

${ }^{636}$ Lesch, op. cit., p. 37.

${ }^{637}$ Lesch, op. cit., Muslim Arabs sectarian parties of the Umma and Khatimyyia of the DUP united in 1958 and constituted a constitution that considered Sharia, the source of laws and Arabic as the only language of work in the state. The non-Muslims of the South mainly Animists and Christians rejected the constitution and walked out from the parliament. During their absence, the Muslim Arabs as the majority continued to secure the adoption of such laws in the constitution, until the coup erupted and obstructed the implementation.
} 
democratic approach is 'tyranny', since the majority neglects the rights of minorities and legitimates assimilation in the democratic circumstances. ${ }^{638}$

Sociologists have no uniformity in defining assimilation. Steinberg defines it as a total obliteration of ethnic diversity in social structures for the purpose of establishing superficial uniformity of ethnic identity within a territory. Its adherents use it systematically to eradicate the existing differences that distinguish minorities as unique and to substitute such differences with the culture of the dominant ethnic group. ${ }^{639}$ This definition conforms to the form of assimilation that some of the students claim to be operating within the institutions of Sudan. For instance, a Dinka Christian Animist argues: "Muslim Arab politicians in Sudan ... try to constitute a constitution that assimilates us; it is an assimilation that takes away every cultural practices of the Dinka. It takes away our religion and imposes their religion. A practice that looks so deeply strange, since it takes way and only takes. It is difficult for me when I think of it to find a word describing it; it is anomia. All in all, it takes away everything of our cultural environment and transforms us to an Islamic identity. It is really an anomia; however, it kills its resisters to its trend of assimilation." ${ }^{640}$ The term anomia which the student uses in describing the measures taken in transforming the nonMuslims to the Islamic identity in Sudan is of great significance for the analysis of the assimilation in Sudan. It provides us with an insight to the way ideological assimilation works. Its application to the non-Muslims in social and political institutions eradicates all unique cultural religious and ethnic characteristics and sometimes; it turns to violence to the extent of killing it resisters. Second, in order to have a comprehensive knowledge of the term, we must resort to its linguistic meaning. The word anomia refers to a difficulty that a person faces in finding the correct word to describe a specific situation of event. ${ }^{641}$

Taking into consideration the origin of the term in association to the student view towards assimilation in Sudan, then the anomia assimilation is defined as a difficulty that faces an intended person for assimilation to find a word that can describe the measures taken by power in state in eradicating diversity and imposing uniformity of cultures in Sudan. In other words, its application in public institutions creates a difficulty in the mind of an affected person to find a word describing its consequences, because its effects look bizarre, freakish and incongruous to his mental and cultural

\footnotetext{
${ }^{638}$ Cunningham, Frank (2002). Theories of Democracy a Critical Introduction, London: Routledge, p. 15.

${ }^{639}$ Steinberg, op. cit., p. 47.

${ }^{640}$ Thon Yuot, University of Juba.

${ }^{641}$ Yule, op. cit., p. 130.
} 
vocabulary. Since, it totally eradicates differences and inserts uniformity by elevating the intended unique culture among other cultures through different methods, including legal ones and the use of violence.

The political institutions of contemporary Sudan show that some ruling democratic multi-parties have been introducing assimilating measures for suppressing minority ethnic cultures. The procedures have been aimed at eradicating certain groups as distinct people in a clandestine way. They have sent military forces disguised as civilians to kill those opposed to the objectives of assimilation. The intended victims of assimilation have resorted to seeking the means of resisting eradication and continue to perform their cultural habits. Two scholars observe this kind of assimilation; first, Nor Adam says that under the democratic pluralism of Sadiq Al-Mahdi, before June 1989, observers were dissatisfied with the presence of insecurity among the emigrants from minority ethnic groups from South Sudan and Darfur within the boundaries of the Northern Sudan. For instance, in 1989 a massacre of some Christians and Animists from the Shilluk ethnic group took place in the presence of security forces in the town of Jabellein along the White Nile region of the Northern Sudan. Anor Adam concludes that some Human Rights Agencies suspect that some security men masqueraded as ordinary Arab civilians and participated in the massacre of the Shilluk. ${ }^{642}$ Second, Cheadole and Prendergast say that the massacre of the African Dinka in 1987 at the town of Dhein by the Muslim Arabs of Reizegat was followed by the massacre of the African Shilluk under the democratic regime of Sadiq Al-Mahdi. Both political massacres send a signal of insecurity to the Black African populations within the territory of Sudan. At least some indigenous ethnic groups from Darfur took note and remained vigilant to defend their villages which had been under constant attacks from the nomadic Arab Muslims in the region while the democratic regime of Sadiq Al-Mahdi failed to protect them. ${ }^{643}$

\subsection{Anomia assimilation}

A majority of the interviewed students claim that all the systems of autocratic, aristocratic, theocratic and democratic regimes which have ruled Sudan have applied a political pattern of assimilation that intends to aggressively eradicate the uniqueness of the Christians and the Animists

\footnotetext{
${ }^{642}$ Nor Adam, Baballa Haroun (1999). "Ethnic Composition, Economic Pattern and Armed Conflicts in Darfur", the Sudanese Human Rights Organization, the Sudanese Human Rights Quarterly, Issue No. 8, p. 19.

${ }^{643}$ Cheadole, Don and Prendergast, John (2007). Not on Our Watch: The Mission to End Genocide in Darfur and Beyond, Washington: Hyperion Books, pp. 58-59.
} 
of South Sudan. ${ }^{644}$ Such a form of political assimilation characterises the successive systems of power in Sudan as, according to one student, a group that is 'detrimental to the wellbeing' of the people of Sudan in their different social structures". 645

Description of the successive leaders in control of power in Sudan as 'detrimental' for the 'wellbeing' towards the citizens requires some sociological analysis. This description of Sudanese leaders puts the Sudanese society in a political situation of no 'wellbeing' in sociological theory. Harris defines society as a composition of a group of people sharing a common habitat and usually depending on one another for their "survival and wellbeing". ${ }^{646}$ The claimed treatment of the Government of Sudan to its citizens justifies that there has been no Sudanese society that depended on the survival and wellbeing of social and cultural categories, rather than, the anomia assimilation. For instance, the Students give testimonies of the current application of anomia assimilation by the present ruling government NCP, under President Al-Bashir. According to them, the system recruits the paramilitary organisation, PDF and entrusts it to fight the rebels, but in practice it targets those who resist the process of Islamisation and Arabisation of the state. ${ }^{647}$ During its operations, the PDF has deliberately attacked the Muslim, the Christian and the Animist civil population in South Sudan, Nuba Mountains and Ingessana Hills, because of their resistance to mashurua el-hathari (the project

\footnotetext{
${ }^{644}$ Lul Agany, a Dinka Christian Animist at University of Upper Nile argues “... for a century, we have been under assimilation from the autocratic, theocratic and democratic regimes who ruled Sudan, until today". Thwal Luak, a Nuer Christian Animist argues: "Whenever, we refuse Islamisation and Arabisation; we face Jihad in the South". Achan Dheiu, a Dinka Christian Animist, University of Juba states: "Democratic regimes intend to make us Muslims and when our generation refuses, then the Muslim Arabs start ethnic cleansing and genocide. They believe that we are pagans; therefore, we deserve murder and a murderer receives a reward from the Heaven of the Muslims' God".

${ }^{645}$ Adut Deng, a Dinka Christian Animist, University of Bahr el-Ghazal argues: "Different bad systems of theocratic Muslim Arab rulers in Sudan make Sudan looks in humane. The Muslim Arab leaders are very clumsy, insulting and disrespectful group to the wellbeing of the Sudanese as a society". Munsur Muhammed Yusuf, a Zagahwa Muslim, University of Juba argues "... our wellbeing as a society is supposed to be observed by our rulers. Muslim Arabs in power divide social institutions into good Arab Muslims and bad African Muslims with Christians and Animists of the South".

${ }^{646}$ Harris, Marvin (1987). Cultural Anthropology, New York: Harper \& Row, p.7.

${ }^{647}$ Mursal Osman, a Nuba Muslim, University of Juba said President Omer Hassan el-Bashir recruited militia, popular Defence Force. This body is entirely composed of Muslim fundamentalists who want everyone to bow down as a Muslim.
} 
of civilisation). ${ }^{648}$ It is an Islamic project that intends to convert the territorial citizens of Sudan to Islamic fundamentalism and kill those who attempt to resist it. ${ }^{649}$

It has become visible that mashurua el-hathari and the PDF are inter-independent organisations, where mashurua el-hathari is an Islamic ideology that aims to assimilate Sudan's cultures into an Islamic one. And at the same time, the PDF is a militia organisation that implements the defined objective of the mashurua el-hathari of anomia assimilation. These allegations of students that mashurua el-hathari kills those resisting it have been confirmed by some Human Rights institutions and the Sudanese media. For example, the Sudanese Human Rights Organisation (SHRO) reports that the NCP with its militia the PDF pursue extra-judicial killings against those who resist mashurua el-hathari in Sudan. During the 1990s, the government recruited the PDF militia under General Tom el-Nur to hunt for the Dinka in the largest Dinka city of Wau in South Sudan. Many Dinka civilians, including Luka Ngor, Director General for Forestry Department were murdered by the militia in an open place and the government did not react. Government soldiers applied the same policy of killing the Dinka on 14 June 1998, when fourteen Special Guards of the Governor of the Northern Bahr el-Ghazal State, Kuwac Makuei, a Dinka, were collected and taken to the shared garrison of the army and the PDF at Mathiang, two kilometres from the capital city of the state, Aweil. The SHRO concludes that all fourteen were shot by an intelligence officer, Abdel Basit in charge of the promotion of the mashurua el-hathari. ${ }^{650}$

The leaders of Sudan constantly emphasise in the public media and political rallies the two terms, mashurua el-hathari and the PDF. First, Nafi Ali Nafi, Presidential Assistant, Deputy to the Chairman of the NCP and Head of the Political Mobilisation in the party threatens the international community as follows: "The price of our relationship and cooperation with the international family over the issue of Sudan's identity cannot be compromised at the expense of Sharia. We are not

\footnotetext{
${ }^{648}$ Rabah Abdel Rahaman, a Muslim Nuba, University of Juba states: "Popular Defence Force is a notorious militia. It has committed genocide against the moderate Muslims, Christians and Animists who reject the civil orientation of Islamism in Sudan". Eisa Adam Muhammed, University of Khartoum argues: "Popular Defence Force is an organisation that has deliberately committed crimes against humanity in our territories of South Sudan, Ingessana and Nuba Mountains".

${ }^{649}$ Mustafa Muhammad Adam, a Zagahwa, University of Khartoum states: "Christians and Animists of the South and Nuba Mountains were killed by the militia, PDF. The victims are killed, because they resist mashurua el-hathari. Now, they have turned to kill the moderate African Muslims in Darfur".

${ }^{650}$ Human Rights (1999). "Human Rights Situation in Sudan, Extra-Judicial Killings", the Sudanese Human Rights Organisation, the Sudanese Human Rights Quarterly an Ad hoc Publication, Issue No., 8, pp. 46-47. The detained Dinka and latter killed in Aweil included, Majok Amol Amol; Joseph Garang Dut; John Garang Bol; Santo Mawein Manon; James Malek Manon; Peter Deng Dut; James Akol Mawein; Peter Puol Kuol; Sabit Lual Kuol; Pol Ngong Deng; Marko Mawein Deng; Garang Kwac Do; Mawein Dau Jong; Kur; and Jal Ajal Deng Gai.
} 
stupid, not illusionists, nor dreamers, and we do not ask reconciliation and relationship from any one; we will defend mashurua el-hathari by all means". ${ }^{651}$ At another rally, Nafi threatened the SPLM after its temporary withdrawal from the Government of National Unity (GONU) in November 2007 saying that: "It is an illusion to the SPLM to think that democracy means the change of the skin of the National Salvation Revolution. Our policy is behind our slogan no god except God of Muhammed; the Messenger of God that is the intrinsic cell of the mashurua elhathari", 652

Second, addressing a mass rally in the second largest city in Sudan, Wed Medeni Stadium, during his political disagreement with the SPLM over the implementation of the 'Comprehensive Peace Agreement', President Al-Bashir threatened that: 'Now, we order the PDF, the legitimate son of the people to open their camps and gather Muslim Holy Warriors not to fight, but to be ready for war". 653

Whenever there is political resistance to the territorial Islamic and Arab assimilation from the Christians and the Animists of the South, the successive Governments of Sudan have preferred to resume war as a means of addressing assimilation. The result of this has caused a massive death toll of the civilian population in the South. Malwal observes that it has become an apparent policy to Muslim Arab northern governments to treat every Christian and Animist of the South as a rebel, whether or not he is a soldier. ${ }^{654}$ Treating every Animist and Christian Dinka as a rebel is a typical paradigm of anomia assimilation based on the inclusive killing of the territorial residents as enemies. Richard Williamson, a Presidential Special Peace Envoy of President George W Bush to Sudan reported on the fate of the Christians and the Animists of Abyei area between the borders of the South and the North in an informal session of the UN Security Council. Williamson said that on 16 May 2008, Sudanese army Brigade 31 attacked the Dinka Ngok Christians and Animists town of Abyei in South Sudan. During the attack, the soldiers committed a deliberate and brutal killing of an

\footnotetext{
${ }^{651}$ Ray Aam, (2008, April 24). “Nafi Ali Nafi: Sanedafa Mashurua el-Hathari be kul wasael, Nafi Ali Nafi: We will Defend the Project of Islamic Orientation by All Means”, Arabic Newspaper Ray Aam, Issue No. 9810, p. 1. www.http://.rayaam. net.

${ }^{652}$ Ray Aam (2007, October 16), "Nafi Ali Nafi Yakathib al-Jamaheer fil Gatharef, Nafi Ali Nafi Addresses People in Gadaref”, Ray Aam Arabic Newspaper, Khartoum, p. 3. www.http://.rayaam. net.

${ }^{653}$ Shreq al-Awast (2007, November 18). "Sudan's President Orders Paramilitary Forces Mobilisation, Rejects Abyei Report", Shreq al-Awast English Version, Issue No. 10582.

${ }^{654}$ Malwal, Bona (1981). People and Power in Sudan: The Struggle for Stability, London: Ithaca, p.96.
} 
unspecified number of the Dinka civilian population. Their residential homes were burnt to ash and looting took place. ${ }^{655}$

Some students claim that there has been no regime in Sudan free from oppression of the people of the South, neither autocratic nor democratic. Students provide historical instances. First, in August 1955, the departing British Governor-General of Sudan, Sir Alexander Knox Helm tried to persuade the Southern Corps that had mutinied in Torit town in order to resist assimilation into Arab Muslim culture to surrender to the Northern Arab forces. ${ }^{656}$ When some agreed to surrender, the government under Ismail al-Azhari a Muslim Arab ordered its troops to massacre them. ${ }^{657}$ Second, during the reign of General Ibrahim Abboud, military planes were used to bombard non-combatant civilians of the South in their villages; meanwhile the locations of the rebels were in the caves of mountains and not villages. Civilians were massacred in the towns of Yei and Juba of the Southern Sudan. ${ }^{658}$

The tenure of Abboud was a critical time for the Christians and the Animists of the South. The military regime emboldened its Muslim cohorts to embargo diversity of cultures and to extradite Christian missionaries from the South. The indigenous territorial peoples were put at the brink of cultural extinction as citizens in Sudan. According to Lesch, Abboud introduces measures for assimilation, under the model of Islamisation and Arabisation. He argues that the unity of the country must be based on eradication of Christianity as an alien religion brought by the Christian missionaries to the South. In May 1962, the government instituted a bill, the Missionary Societies Act, which forced the Chiefs of Azande and Toposa to convert into Islam together with their people. Friday was substituted for Sunday as the resting day. Mosques and Muslim schools were allowed to be erected in different locations in the South, in opposition to chapels and churches. ${ }^{659}$

Students provide more examples of anomia assimilation concerning the second democratic rule in Sudan from 1965, under Muhammad Ahmed Mahjoub of the Umma party. During that regime the Christians and the Animists of the South experienced tragic events they have still not forgotten. On

\footnotetext{
${ }^{655}$ UN (2008, June 18). "Highlights of the Noon Briefing by Michele Montas, Spokesperson for the Secretary General Ban Ki-Moon, UN Headquarters", New York, p. 1

${ }^{656}$ Abker Ibrahim, a Muslim Zagahwa, University of Juba stated: "A former British Governor intervened in the battle between the Northern Muslim Arab soldiers and the Southern Christian Animist rebels to put down their arms and join the North".

${ }^{657}$ Anur Idris, a Zagahwa, University of Juba: "Some of the Southern soldiers who surrendered with hope to be forgiven as priory agreed were massacred by the democratic Premier Ismael Al-Azhari".

${ }^{658}$ Mariam Tom, a Nuba Muslim, University of Khartoum argues: "History of Sudan is not good; during Abboud from 1958-1964, the autocratic regime exerted its efforts to Arabised and Islamised the population of the South. When it had become clear that they were not submissive, planes were applied to kill them".

${ }^{659}$ Lesch, op. cit., 38.
} 
8 July 1965, the government soldiers reduced to rubble some three thousand grass thatched houses and "massacred in cold blood" more than one thousand men, women and children in Juba the capital of South Sudan. ${ }^{660}$ Three days later soldiers "murdered" seventy-six persons in Wau capital city of the Greater Bahr el-Ghazal at a Dinka wedding party. ${ }^{661}$ In August the army attacked the Shilluk village of Warajwok, a few kilometres south of Malakal, where one hundred and eighty seven "Collo people were massacred in cold blood". ${ }^{662}$ More tragic events occurred at the village of Arini, near the town of Akobo, where forty-five Nuer men were massacred and left to be eaten by the vultures. ${ }^{663}$

The third term of the democratic multiparty system in 1986-1989, under Sadiq Al-Mahdi of the Umma Party was a disastrous time for the Christians and the Animists. A democratically elected government did not observe the values of democracy towards the people of the South. In broad day light in the town of Dhein, the Dinka were massacred by a conspiracy between the police and the Reizegat Muslim Arabs. ${ }^{664}$ The claims of the students have been documented. According to Deng, the power system in Sudan has been in the hands of the Northern Muslim Arabs and after the rebellion of the South in 1955 against their domination, they reacted by brutalising the rebels and the civilian population alike. Civilians' urban, rural centres and villages in three provinces of Equatoria, Bahr el-Ghazal and Upper in the South were incinerated. ${ }^{665}$

It appears that 'anomia assimilation' has developed into its worst stage, under the current system of monolithic ideology of Islamic fundamentalism of President Al-Bashir. The application of Jihad in fighting Muslims, Christians and Animists people of the South, Nuba Mountains and Ingessana Hills as group resistant to the system of Islamic fundamentalism aggravates anomia assimilation in those regions. Yet, even radical ideologies based on war cannot rely solely on violence. They resort also to negotiation in order to reach a political settlement with the dissidents. Two views support this claim. First, in his pastoral letter on 17 November 2000, the Sudanese Catholic Bishop of ElObeid Diocese, Macram Max Gassis revealed the catastrophic situation that Jihad has caused to the people of South Sudan, Nuba Mountains and Ingessana Hill. He stated: "Nothing seemingly penetrates the indifference to Jihad in Sudan. Under Jihad of the National Islamic Front of Al-

\footnotetext{
${ }^{660}$ Mayar Akol, a Dinka Christian Animist, University of Juba.

${ }^{661}$ Ayuel Ajuet, a Dinka Christian Animist, University of Juba.

${ }^{662}$ David Majwok, a Collo Christian Animist, University of Upper Nile.

${ }^{663}$ Paul Riek Gath, a Nuer Christian Animist, University of Juba.

${ }^{664}$ Ahmed Sadiq Hashim, a Fur Muslim, Omdurman Ahlia University.

${ }^{665}$ Deng (1995), op. cit., pp. 142-3.
} 
Bashir, hundreds of young girls ... have been abducted and made to be concubines to Jihadists. Under Jihad, houses of the civilians in Nuba Mountains have been bombarded leaving the dead and maimed people spread everywhere. Under Jihad, the people of Bahr el-Ghazal are rounded up in their villages and sold into slavery. Under Jihad, starvation of the Christians, the Animists and moderate Muslims of Nuba Mountains, Ingessana Hill and South Sudan have been planned as a weapon of war". 666

Second, a Nuba student claims: "When Omer Hassan Al-Bashir seized power with the intent to promote his 'Islamic fundamentalism', he first wanted to kill all pagans in the South, Ingessana Hills and Nuba Mountains. He did kill many of them with his Jihadists, the PDF militia, yet he could not ... finish them all. Hence, he dropped his conservative Islamic trend and reasoned with the Muslims, the Animists and Christians of these regions and that brought the Naivasha Peace Agreement in 2005". 667

An analysis to the imposition of 'anomia' assimilation by political demagoguery in the national institutions of Sudan projects all democratic, theocratic and autocratic systems in Sudan into a series new political dimension. It stimulates other classes within the institutions of state to perform a practice that reflects a lust to power. Virtually, the practice encourages military juntas to capture power and transform the existing democratic systems based on pluralism into unilateral ones based on the method of aggressive dictatorship that exerts political efforts to eradicate religious pluralism. El-Affendi observes that the conflict between the Christians and Animists of the South as advocates of the democratic pluralism and the Muslim political forces of the North as advocates of the Islamic law has led to the capture of a democratic power. The first instance of this occurred in November, 1958 when Major General Ibrahim Abboud seized the democratic elected government of the Prime Minister, Abdullah Khalil Bik of the Umma Party. El-Affendi concludes that Abboud became an aggressive dictator and closed institutions which were un-Islamic in the Christian South and its military forces killed resisters. ${ }^{668}$

Imposition of 'anomia' assimilation also revives ethnic and racial cultural identity, rather than, a religious cultural uniformity based on Islam. In other words, its application makes African Muslims of the Nuba Mountains, Darfur and Beja of the eastern Sudan drop the Islamic culture that unifies

\footnotetext{
${ }^{666}$ Macram Max Gassis (2000, November 17). "Suffering of the People in Sudan” Pastoral Letter, pp. 1-2.

${ }^{667}$ Shiraz Ahmed, a Muslim, Omdurman Ahlia University.

${ }^{668}$ El-Affendi (1990), op. cit., p. 373.
} 
them with Muslim Arabs of the North. These African Muslims from the marginal zones of Sudan unite with the African Christians and Animists of the South and resist 'anomia' assimilation. ${ }^{669}$

To explain these views of Muslim students from these regions one must compare them with the views of the Christians and the Animists from the South and Nuba Mountains. This matter has been dealt in the research question that asks: how do you want the identity of Sudan to be defined in a national constitution and why do you think so. A Nuba Muslim student claims that "We the Nuba become one with the Christians and the Animists of the South, when Muslim Arabs call for the application of Sharia constitutionally in Sudan. We are Africans as those Christians and Animists are also Africans. Sharia does not leave any room for our African traditions to co-exist with Islam, so we stand together in resisting it" ${ }^{670}$ For a Beja student "It is true that we can come together as umma in faith, because we are Muslims, yet we the Beja in general ... have our unique cultures which Muslim Arabs intend to wipe away, so we unite with other indigenous Africans in the west, centre and South Sudan to resist Islamisation and Arabisation of the state constitutionally". ${ }^{671}$ And a Fur Muslim from Darfur argues that: "The so-called North Sudan of Muslim Arabs versus South Sudan of the Christians and Animists is a construct of colonialism. The dominant Muslim Arab political parties at the centre of Sudan exploited that exclusion of the Christians and the Animists at the South. Muslim Arabs in power 'cheated' the indigenous people in Nuba Mountains, Darfur, Ingessana Hill and Beja at the east by propagating ... that the people of the South are pagans and Trojans of the Christian West, which wants to extirpate Islam and Arabs in Sudan and separated us. ${ }^{672}$ One Muslim student concludes: "It was, under this deceptive political propaganda that the illusive political North collectively fought the South for almost half a century. In essence, our ... problem is not the so-called the pagans of the South, but it is a total lack of constitutional political objective that could sustain political aspirations for the territorial citizens". ${ }^{673}$ On the other hand, Christian Animist students present their claims as: "Historical building of national institutions in Sudan reflects one culture of 'Islamism' and 'Arabism', and the application of this culture within these institutions divides the state into two entities, the African Christian-Animists from the South

\footnotetext{
${ }^{669}$ Lesch, op. cit., p. 37. During the discussion for the constitution of 1958, the dominant political parties of Umma and the DUP urged the application of Sharia, but the African Christian Animists from the South united with the indigenous Muslims of Darfur, Beja and Nuba and pressed for the decentralisation of the system, under diverse laws.

${ }^{670}$ Tareq Khdier, University of Khartoum.

${ }^{671}$ Mohammad Surur, University of Khartoum.

${ }^{672}$ Samira Al-.Nur, University of Juba.

${ }^{673}$ Zubeda Abdullah, a Nuba Muslim, University of Khartoum. Khalid Mubarek, a Muslim Hadendawa, University of Khartoum. Nadia Karim, a Muslim Fur, Darfur.
} 
and the indigenous Muslims people of Darfur, Nuba Mountains, Ingessana Hill and Beja in opposition to the Muslim Arabs." ${ }^{674}$ Another student claims: "The division between us as Christian, Muslims and Animist Africans in resisting oppressive forces of Muslim Arabs is rooted in our hearts and it makes it very difficult to select any constitutional systems that may suit ... Sudan, including democratic or militarily constitutional secularism". ${ }^{675}$ One student concludes: "We have tried all those systems and none of them has been observed by ... Muslim Arabs in power. Instead, power ... promotes an Islamic religious sectarian constitution in National Parliament, under the basis of being Muslim majority at the expanse of Christian and Animist minorities. At this circumstance, our indigenous African Muslims from the west and the east stand with us in resisting Arabism and ideological Islamism". 676

The problem of constructing a national identity places Sudan in a state of continuous political instability. Only a stable and a compromising constitutional system accepted by all the diverse religious faiths could restore the lost trust between the marginal people in the South, Darfur, Beja and Nuba Mountains and the Centre. Hassan observes that the problem between the Muslim North and the Christians and Animists of the South is a difficult task that prevents a unified constitution. Some Sudanese hope that political unity will prevail; however, the presence of the radical organisation, NCP of Al-Bashir in power makes it impossible to achieve one constitution for the Sudanese nation. ${ }^{677}$ Responses of some students to the research questionnaires provide us with different alternative views to the political crisis of national identity in Sudan. Some claim that there is no constitution that could unite the diverse citizens of the South with Muslim Arabs at present and in the future. ${ }^{678}$ Often, Muslim Arabs deceive people in conferences and refuse to implement the agreed constitutional issues. Respect for the identity of the minorities' ethnic and religious background is a remote hope in a united Sudan. ${ }^{679}$ One Dinka student concludes that: "Many of us hate lies and this makes the territorial Sudan as a sovereignty composed of contradictory societies. Most of Muslim Arab leaders at the North are 'liars' and most of the political forces of the

\footnotetext{
${ }^{674}$ Both Riek, University of Juba.

${ }^{675}$ Awel Atak Akol, a Dinka, Bahr el-Ghazal University.

${ }^{676}$ Santino Abel, a Dinka Christian Animist, University of Juba.

${ }^{677}$ Hassan (2007), op. cit., pp. 56-57.

${ }^{678}$ Sadiq Nazeir Osman, a Shaiqqiyyia Muslim, Omdurman Ahlia University states: "We are Muslims and we need Sharia. The South is Christians with majority of Animists who want non-Islamic laws, so we have no common denominator for a unified constitution".

${ }^{679}$ Daud Muhammad el-Naeim, Danaqla, Omdurman Ahlia University argues: "There is no a Muslim Arab leader that is ready to respect diversity of Sudan racially, religiously and ethnically. It is only a hope for the people; so that the country remains united as one Sudan. The imposition of one religious culture and one race threatens unity of Sudan".
} 
Christians and the Animists in the South are principled in telling political truth and maintenance of political promises. ${ }^{680}$

The division this student makes of the political institutions of Sudan into the categories of 'liars' and truth tellers perhaps gives an impression of racial religious egoism and 'ethnocentrism'. ${ }^{681}$ Still, it is a political characterisation derived and theorised from various political developments between the two conflicting populations of the territorial South and the North. Let us take two instances; first, the Minister of Religious Affairs in Sudan, Islaam Ahmed Al-Bashir delivered a speech to the audience in a conference of religious dialogue and co-existence organised in Beirut, Lebanon in 2003. Al-Bashir emphasised in his speech that as a Muslim, his government promotes religious tolerance. Surprisingly, the Sudanese Christian leaders in the conference room responded to his speech that "We had many talks and promises before and nothing had been implemented on the ground to alleviate our suffering in the South". ${ }^{62}$ Second, during the first political negotiations between the Chiefs from the South and the politicians from the North in the 'Juba Conference' in June 1947, Chief Cier Rehan suspected Muslim Arab politicians of the North and said that the Muslims would lie to them, if the two territories, the South and the North were to reunite. Cier stated "The people of the South are distinct culturally from the people of the North; if we join the North, would Muslim Arab politicians listen to our words as representatives of the people of the South?" ${ }^{683}$ Mohammad Saleh Shangethei, a Northern Muslim politician replied: "they would listen". ${ }^{684}$

The recent history of Sudan; however, indicates that Muslim Arabs in power have refused to listen to the successive political representatives of the South and Darfur. The promise of listening has proven to be a ploy to make time pass. Such behaviour builds political mistrust between the population of the South and the Islamic Arab Muslims in power in the North. We have two examples of such mistrust. First, Minni Minawai Arcua, Senior Presidential Assistant and Chairman of the Darfur SLM accuses the Islamic Northern government in power of lie. Minni states: "The

\footnotetext{
${ }^{680}$ Akot Kuol, University of Khartoum states: "Many of us hate lies. Many Muslim Arabs are oriented to be liars. This is not the situation to the Christians and the Animists of the South. We tell truth and keep our political promises".

${ }^{681}$ Robertson, Ian (1987), op.cit, p 290. Most ethnic groups tend to display ethnocentrism, which is a tendency that a group applies to judge cultures of others by the standards of their own.

${ }^{682}$ Middle East (Spring 2003) "Sudanese Muslims, Christians Discuss "Co-Living and Culture of Peace" an Arab Working Group on Muslim-Christian Dialogue Contributes Its Perspective, Middle East Council of Churches , News Report, Vol. 15, No.,1., p. 3

${ }^{683}$ Juba Conference, op.cit., pp. 12-13

${ }^{684}$ Ibid.
} 
Islamic National Congress is a lying organisation... with racial intentions, even in administering the state. ${ }^{685}$ Second, according to Deng, the Dinka Chief Makuei Bilkuei accused the former President Nimeiri of deception and argued: "We the Chiefs what ... we hate is deception. The Arab said; You South, let us unite. If you accept, what they say, then ... open one eye and close the other one. Leave the other one to speak with the Arab. Nimeiri said to us that the country is one, that the black people have been given their own house. Tomorrow we will meet in the field; when we have borne our children in our small huts, but do not accept the breast." ${ }^{686}$ Deng concluded that what the Chief meant by 'breast' was that the Southern Christian Animists are allured and deceived with superficial pleasures. If a woman allows you to touch her breast, then, she can allow you to proceed further. Tomorrow she could go and claim before a court that she had been violated. Holding the breast of the Arab is thus very dangerous. It is a deception to the Christian Animists of the South and will lead into Arabisation and Islamisation by deception. ${ }^{67}$

\subsubsection{Addis Ababa Agreement}

The people of the South originally rebelled against the domination of the Islamic North in August 1955. Later the rebels operated under the political organisation, 'South Sudan Liberation Movement', SSLM. In 1970, Joseph Lagu became the head of this organisation and its military wing known as Anya Nya. A year before, in May 1969, Ja'afer Muhammad Nimeiri, a Major in the National Army of Sudan had seized power from a democratic elected government becoming the president of the state. Nimeiri sought a political settlement between the South and the North under the mediation of the Pan African Council of Churches and he began discussions with the SSLM in May 1971. Additional private discussions were held in Addis Ababa in November, and from them developed full-scale political negotiations in February 1972. In March 1973, the agreement was ratified giving the South 'Regional Government' with its independent executive body the 'High Executive Council'. In 1983, the President reversed his course and withdrew this autonomy by redividing the South into three regions. Daly concludes that the re-division of the South was widely

\footnotetext{
${ }^{685}$ Minni Minnawi (2010, January 22). “Kabir Musahede al-raiz al-Sudani : Amual al-manaheen liamaar Darfur Tazahab lil-Daaya al-Intikhabii lil-Mutamer al-Watoni, the Presidential Senior Advisor: to the President of Sudan: Fund of the sponsors to the Rehabilitation of Darfur Goes to the election Propaganda for the National Congress, Electronic Arabic Newspaper, Sudanile htt//www. Sudanile.com/index.php?options=comcontent\&review=article\&id=10051:2010-01-22-07-34-31\&catid=42:2008-05-19-17-16-29\&Itemid=60

${ }^{686}$ Deng (1978), op.cit, p. 179.

${ }^{687}$ Ibid.
} 
rejected by the Nilotics in Bahr el-Ghazal and Upper Nile former provinces and consequently the war was revived on 15 May $1983 .{ }^{688}$

Some Muslim students argue that the Christians and pagans of South Sudan rebuke both democratic and autocratic rule in Sudan. Under all these systems, the Northern Muslim Arab rulers have signed agreements with the South and say that after a short time: "The pagan Dinka with their brother Nuer would withdraw from these agreements". ${ }^{689}$ For instance, after Major Ja'afer Muhammad Nimeiri took power in May 1969 he appeared as a good 'apostle' to them and eventually gave them 'Self Autonomous Government' in the Addis Ababa Agreement. Still, in the end, the Dinka and Nuer again mobilised themselves and went back into the jungles to start a new rebellion. ${ }^{690}$ On the contrary, Christian Animist students argue that all the systems in Sudan fail to function, because Muslim Arabs remain in power. The reason for this is that they have systematised Islam as the salvation religion for all people, irrespective of individual beliefs. ${ }^{691}$ Nimeiri succeeded to earn the trust of the people of the South and thus they supported him. The reason for their support was his initiative to separate religion from the state. One student states: "The (sic) Addis-Ababa Agreement made him to be accepted in ... home, the South, but later he jumped away and crossed to those carrying the flag of Islamic religious fundamentalism and described this agreement that it was neither the Quran nor the Bible and took it away". ${ }^{692}$ Another one said after that: "Nimeiri imposed Sharia on the Christians and the Animists in order to create his dream of assimilating them into Islam. ${ }^{693}$ Finally, one student concludes: "Because of dismantle of the Addis Ababa Accord, the war resumed in 1983, between us and them". 694

Why indeed, President Nimeiri dropped Addis Ababa Agreement? In the opinions of some Muslim students, Nimeiri had to dismantle this agreement in order to attract the resisting Muslim sectarian political parties of the Islamic ideology into his political camp. ${ }^{695}$ Careful analysis,

\footnotetext{
${ }^{688}$ Daly (1986), op.cit., p. 23

${ }^{689}$ Saleh Maher, Muslim, Shaiqqiyyia, University of Khartoum, None of the systems such as democracy, autocratic, theocratic and military regimes are not respected by the Christians and pagans of the South. The Islamic North signs agreements with them, yet "the pagan Dinka with their brother Nuer" could drop the political covenants and walk into bush in an open day and shoot institutions.

${ }^{690}$ Mawai Taleh, the people of the South do not understand, Nimeiri was the best man for them. He was their "apostle who created for them after Addis Ababa Agreement a Self Government Rule".

${ }^{691}$ Manyel Madol, University of Juba

${ }^{692}$ Mapier Dut Mar, a Nuer Christian Animist, Upper Nile University

${ }^{693}$ Anei Lul Akol, a Nuer Christian Animist at University of Juba

${ }^{694}$ Kuol Deng Anei, a Dinka Christian Animist

${ }^{695}$ Mustapha Magdi Awad, a Muslim Ja'ali at University of Khartoum, Nimeiri concealed Addis Ababa Accord with the South, because he wanted to acquire a support from the Muslim Arabs of the North.
} 
however, of Sudan's politics under Nimeiri shows that the President promoted very contradictory policies towards the Christians and Animists of the South. First, his courageous political initiative to ratify peace with the SSLM in 1973 had attracted the people of the South to his political ideological camp. On the other hand, his unilateral withdrawal of the terms of the agreement culminating in the re-division of the South into three small regions against the regional system defined in the agreement caused political mistrust in the South and led to the resumption of violence in May 1983.

\subsubsection{Nimeiri's multiple conflicts}

The majority of all Muslim students, Christians and Animists view the democratic pluralistic rule as 'the best' system and superior to the theocratic or autocratic ones, but it depends on who is applying it. ${ }^{696}$ The Southern Christian and Animist students claim that the Islamic sectarian religious political parties in Sudan have manifested contradictions in their political approach to the citizens of Sudan. They have advocated the method of democratic pluralism and at the same time, they have contradicted themselves by rejecting its respect to religious and ethnic diversity. For them, it meant the eradication of heterogeneous ethnic and religious minorities and substitution of assimilation to the Islamic-Arab norms of the majority within a unified Sudan. ${ }^{697}$ This approach is entirely stripped of the democratic pluralism as practiced in the Western institutions. ${ }^{698}$ One student concludes that: "The South needs a special treatment that excludes it from the Islamic and Arabic assimilation, but ... Muslim sectarian and secularist democratic forces in the North cheat us and have done so for about fifty years with democratic pluralism that intends to absorb everyone to their Islamic and Arab culture". ${ }^{699}$ Warburg explains that before the independence of Sudan, the Northern Muslim Arabs of the Islamic religious sectarians and the secularists unanimously offered a federal system to the people of the South who wanted it for the preservation of their non-Islamic cultures. This agreement was dropped after independence and the traditional sectarian Muslim leaders of the Khatimyyia and the Ansar agreed to aim at an Islamic constitution as one of their most significant goals. Warburg concludes that the initiative was a reference to the rapid Arabisation and

\footnotetext{
${ }^{696}$ Sarah el-Tom Muhammad, University of Khartoum: "Different systems have been used in Sudan, but "in my opinion, democratic pluralism out of autocratic and theocratic is the best one. Democratic pluralism is better than theocratic, autocratic, but some leaders distort the obligatory values of democratic pluralism of respect to human rights".

${ }^{697}$ John Deng, University of Upper Nile

${ }^{698}$ Awad el-Khatim Hosham, a Nuba University of Khartoum: "Democracy in the Western block stands for pluralism in cultures, but ours is sripped of its values".

${ }^{699}$ Nyanut Ayuel Akol, a Dinka, University of Upper Nile.
} 
Islamisation of the people in the South, which they believed would lead to a Sudan united in cultural identity. ${ }^{700}$

When Nimeiri seized power from these sectarian religious multi-parties, he rejected assimilation and articulated firmly that the unity of Sudan must be preserved on practical social objectives that recognise the cultural differences between the ethnic Muslim Arabs in the North and the African Christians and Animists in the South under the system of 'Sudanese Socialist Union' (SSU). He promoted an ideology of building a socialist society and endorsed laws that preserved respect to the Muslims, the Christians and the Animists as equal citizens constitutionally in Sudan. ${ }^{701}$ Nevertheless, Johnson maintains that Nimeiri later changed his views. After the discovery of oil in the territory of the Christians and Animists in the South in 1980, he introduced a new demarcation that annexed the oil regions to the territory of the Muslim Arab North. This initiative built a new territorial conflict of 'theirs' and 'ours' as demonstrated by the population of the South, which interpreted the new demarcation as a way to capture their natural resources and staged serious demonstrations, which were violently opposed to it. ${ }^{702}$

\subsubsection{The search for the status group}

Students from different ethnic Muslim groups give arguments concerning the imposition of Sharia by Nimeiri and Al-Basher's maintenance of it. Some argue that President Al-Bashir is ideologically unstable. For instance, he overthrew the democratic power and described the civil political violence as a war between the 'socialist pagans' of the South and the faithful Muslims striving to establish Sharia as the law of the land. ${ }^{703}$ And at the same time, he vows to sustain all forms of political, economic and cultural relationships with the Chinese. The culture and economic operations of the government of the People's Republic of China are entirely oriented towards socialist ideology, which does not include the significance of any religion in cultural politics. ${ }^{704}$ In reference to African Rights, President Al-Bashir gathered Islamic clerics in el-Obeid, capital city of the Northern Kordofan on 27 April 1992. In that gathering, the clerics with Al-Bashir defined the violence in Sudan as a religious war between the infidel pagans and Christians of the South supported by the

\footnotetext{
${ }^{700}$ Warburg, Gabriel (1978). Islam, Nationalism in a Traditional Society: The Case of Sudan, London: Frank Cass, p. 140 .

701 Alier, op. cit., pp. 43- 51.

702 Johnson (2003), op. cit., op. cit., p. 46.

${ }^{703}$ Adam Wad Fadol, Fur, University of Khartoum.

${ }^{704}$ Hatim Awad, a Muslim Shaiqqyyia, University of Khartoum.
} 
apostate Muslims of the Nuba Mountains. The resolution of the conference confirmed that the violence was a religious war and must be conducted in religious terms in order to defend Islam and Al-Bashir was announced as Amir el-Mumeneen (the pious leader of the Islamic believers). Under such a religious definition, Al-Bashir immediately declared Jihad against the guerrilla organisation of the SPLM and SPLA in Southern Sudan, Ingessana Hill and the Nuba Mountains. ${ }^{705}$

In contrast, some students claim that Nimeiri overlooked the importance of Sharia in the Muslim community. ${ }^{706}$ "When this soldier came to power; he started to extirpate the powerful will of the Muslims to adopt Sharia for their lives, but we ... forced him to adopt it, because he was left alone without political support from different political forums". ${ }^{707}$ Some claim that Nimeiri, however, imposed Sharia, because, he wanted to appease Muslim sectarian political parties and not due to a personal interest in this law. ${ }^{708} \mathrm{He}$ had lost political backing from his own party, the Communists, and hence needed the support of a new political group. ${ }^{709}$ Two scholars outline the unstable political ideologies of Nimeiri of as un-Islamic and Islamic. First, Johnson maintains that Nimeiri seized power and presented his ideological and political identity as a socialist and a secularist. This ideological definition separated religion from state and banned political institutions that based their politics on the Islamic religion. Under this ideology, the secular communist party, Muslim secularists in the North and the Christian and Animist parties of the South were sufficiently satisfied with the system and joined the cabinet. The official speeches and media disclosures were entirely empty of religious intonation and the cabinet was composed entirely of secularist ministers. ${ }^{710}$ Second, Lesch says that Nimeiri lost the political backing of the Sudanese Communist Party in 1971, and was left with a huge support from the population of the South which he gained, after the signing of peace agreement with the Southern revolutionaries in Addis-Ababa in 1973. Yet, some influential political forces from the South deserted him claiming that the President frustrated them with his unstable political performances, especially, his imposed plan of digging the Jonglei Canal

\footnotetext{
705 African Rights (1995). Facing Genocide: the Nuba of Sudan, London: African Rights Publication, p. 287.

${ }^{706}$ Muhammadeen Taha, a Shaiqqyyia Muslim, Omdurman Ahlia University.

707 Tom Ali Muhammad argues: "Nimeiri took power as a soldier and applied his power to the destruction of the need of the Muslim majority to adopt Sharia as a law. At the end, we forced him to adopt it, because he was politically left alone".

${ }^{708}$ Swaad Tom Salaheen, a Fur: "Nimeiri's application of Sharia was not of his belief, but was a political aim to attract his political dissidents, Ansar and Khatimyyia sectarian parties into his autocratic military system".

${ }^{709}$ Nur Al-Huda Muhammad: "When Nimeiri came to power, he was backed by his political comrades, the Communists". Majid Saeed: "In 1973, Nimeiri disagreed with the Communists and assassinated their leaders. So, he had to impose the will of the sectarian Muslim parties who asked for the adoption of Sharia and became the law now in Sudan".

${ }^{710}$ Johnson (2003), op. cit., p. 36.
} 
along the Nile to drain water from the swamps of the White Nile and his attempt to annex the productive Southern oil areas to the Northern territorial zone of the Islamic Arab North. ${ }^{711}$

Multiple and contradictory political actions by Nimeiri and Al-Bashir with different political forces characterise them as metamorphosis Presidents. Their actions can only be analysed by adopting a social theory. In the social view, society is structured on conflicting groups that contain a 'status group'. It is a composition of individuals that share a common culture, such as their style of life, profession and specific prestige in social, political and cultural categories within a certain territory. ${ }^{712}$ Recently, Al-Bashir has dismissed his earlier definition of the government waging a religious war between the pagans in association with the Christians in support of the apostate Muslims. Addressing the annual Coptic (Christian Egyptians) religious occasion organised in the Coptic Club of Khartoum on 12 September 2008, Al-Bashir declared that the former violence between the SPLA and the government forces was not a religious war between the Muslims on one side fighting the pagans the Christians and the apostates at the other side. It was merely a political violence based on the scarcity of economic resources and the wrangle over power sharing. ${ }^{713}$

It is likely Al-Bashir rejected the religious connection of the war, because, he was seeking the support of the 'status group' the Coptic community in Sudan at the ballot box. On 9 January 2005, Al-Bashir signed the CPA with the former rebels, the SPLM. Article 1.6 paragraph 1.6.2.11 of this agreement states: "Every citizens shall have the right and the opportunity, without distinction and unreasonable restrictions, to vote and to be elected at a genuine periodic elections, which shall be by universal and equal suffrage and shall be held by secret ballot, guaranteeing the free will of the electors". ${ }^{714}$ The same situation applies to Nimeiri. He was eventually left without powerful political forces to rally behind his ideological system of "socialism". ${ }^{715}$ Hence, he resorted to the religious laws in order to find a new status group. Durkheim says that religion provides a vital function in maintaining the social system as a whole. It originated from social interaction, rather than, a supernatural one. For this reason, common practices of religious rituals create deep solidarity of a society. For example, the religious rituals of Christmas, funerals, baptism, Ramadan

\footnotetext{
${ }^{711}$ Lesch, op. cit., p. 46.

${ }^{712}$ Morris, Brain (1987). Anthropological Studies of Religion and Introductory Text, London: Cambridge University Press, p. 79.

${ }^{713}$ Ray Aam (2008, September 12). "Al-Bashir: Sudan lem ya-Shad Saraen Diniaen awau Irkia. Al-Bashir: Sudan Has not Witnessed neither Religious Violence nor Genocide”, Arabic Newspaper, Ray Aam, Issue No. 9876, p. 1.

${ }^{714}$ Comprehensive Peace (2005, January 9). Comprehensive Peace Agreement between the Government of Sudan and the SPLM/A Kenya Nairobi.

${ }^{715}$ Lesch, op. cit., p. 46.
} 
(Islamic holy month of fasting) and the Sabbath and other religious occasions remind a society of its common group membership. ${ }^{716}$

During the time of political crises in Sudan, Nimeiri began to regularly attend the Islamic religious rituals. ${ }^{717}$ The new move of Nimeiri can be interpreted as a way to remind Muslims that he was of their 'status group' and that he needed them. According to Khalid, some leading 'Muslim Brotherhood' figures from the banned Islamic political party ICF took Nimeiri to visit the Chieftain of the Sufi order, namely Awad Al- Jiid Muhammad Ahmed. During their meeting at the rite, Awad Al-Jiid communicated to Nimeiri that he had "a telepathic communication" 718 with the Prophet Muhammed, and in that communication; the Prophet told him that President Nimeiri would apply Sharia in institutions of Sudan. ${ }^{719}$

The statement of Awad Al-Jiid to the President Nimeiri that mentioned Sharia is a conditional reference for accepting him to the Sufi religious order. It required him to re-consider his ideological belief in secular socialism. ${ }^{720}$ After this meeting, members of the ICF, including their Head, Hassan Abdullah Turabi were appointed to the cabinet. Some concerned supporters complained how the Islamists could join this government, which had destroyed their Islamic and Arab ideology in Sudan. Turabi answered that his political association had decided to collaborate with the President, in order to reform the institutions within ${ }^{721}$

\subsubsection{Religious fundamentalism}

Although, the term 'fundamentalism' originated from an old language, Latin as fundamentum meaning base ${ }^{722}$, it has characterised contemporary sociological and political scholarship of the Western institutions ${ }^{723}$, most Muslim and Christian students interviewed reject the association of

\footnotetext{
${ }^{716}$ Durkheim, Emile (1895). Rules of Sociological Method in George E. Catlin (ed.) Sarah A. Solova and john H. Mueller (trans.) (1964). Major Works of Emile Durkheim, New York; Free Press, p. 79.

${ }^{717}$ Lesch, op.cit., 243.

${ }^{718}$ Khalid, Mansour (1987). The Government They Deserve: The Role of the Elite in Sudan's Political Evolution, New York: Kegan Paul International, pp. 277-279.

${ }^{719}$ Ibid.

${ }^{720}$ Warburg (2003), op. cit., pp. 121-122.

${ }^{721}$ Lesch, op. cit., p. 52.

${ }^{722}$ Heywood, Andrew (2003). Political Ideologies, an Introduction ( $3^{\text {rd }}$ ed.), Hampshire: Palgrave Macmillan, p. 292.

${ }^{723}$ See Antuon, Richard T. and Hegland, Mary Elaine (eds.) (1987). Religious Resurgence. Contemporary Cases in Islam, Christianity, and Judaism, Syracuse: Syracuse University Press. See Hawley, John Stratton (ed.) (1994). Fundamentalism and Gender, New York: Oxford University Press. See Boschen, Timothy L and Charlottesville VA (2006). "Shame and Guilt in Religious Fundamentalism" http//www.jmm.aaa.net.au/articles/14422
} 
their religions with this term. Muslim students argue that religious fundamentalism originated from Christianity and that it continues to reflect itself in it, but does not affect Islam. ${ }^{724}$

In turn, the Christian Animist students reject this view and argue that religious 'fundamentalism' is deeply rooted in Islamic Sudan. ${ }^{725}$ They claim that, during the war in the South the government inculcated 'Islamic fundamentalism' into the multitude of Jihadists, the PDF. The members of this Islamic organisation were given homilies at the Islamic religious centres claiming that: "If any one of them kills a Christian, a Muslim or an Animist at the side of their enemy, the SPLA then the killer would certainly enter into heaven, where he would marry hurris (heavenly virgins) and ... the killed opponent would get to hell. And if he was killed by a Muslim, a Christian or an Animist at the side of the SPLA, then his sins on the earth were forgiven in heaven and he would marry in heaven to virgin angels". ${ }^{726}$ One student concludes that in this sense: "We have no place in heaven in all ways and such egoistic religious exegesis of Islamic scriptures represents fundamentalism in religion". ${ }^{727}$ According to Salih, the Government of Sudan, under President Al-Bashir has reconstructed the concept of Jihad towards what it calls iris al-shaheed (wedding of the martyrs). This form of religious reconstruction stimulates members of the government militia, PDF to avoid marriage with the women living with them in Sudan. The women of the earth hurr al-dunia (dark eyed virgins of the earth), and they hope to marry in Paradise huur al-jinna (dark eyed virgin of the Paradise). Salih concludes that the government agents instructed the families of the militia to treat the death of their loved ones in the Jihad with jubilation, and should not mourn, since death is iris al-shaheed, the wedding of the martyrs, which should be celebrated also on earth as in heaven. ${ }^{728}$

These dichotomies between the views of some of the Muslim students with some of the Christian and Animist students call for tracing the origin of religious fundamentalism. Each side claims that the other practices religious 'fundamentalism' as an ideology. The claim of the Muslim students that religious 'fundamentalism' is inherent in the Christian religion is unequivocal. Historically,

\footnotetext{
${ }^{724}$ Asharef Muhammad Suliman, a Ja'alei, University of Khartoum: "Religious fundamentalism does not exist in Islam. It is in Christianity". Sharif Silman Mohammed, a Shaiqqiyyia, University of Khartoum: "The way the Christians conduct their worship reflects the continuity of fundamentalism in their religion". Zeriba Ahmed Mohammad, Hawazama, University of Juba: "Islam is free from fundamentalism. Christians are the fundamentalists".

${ }^{725}$ Ring Cier, a Dinka, University of Juba: "Islam is a religion, but Sharia proves its fundamentalism”.

${ }^{726}$ Kur Alieu Yel, a Dinka, Omdurman Ahlia University.

${ }^{727}$ Abel Majok, a Dinka, University of Upper Nile: "Islamic fundamentalism in Sudan leaves no space for us. During the war, Muslim fundamentalists killed us and claimed that we had no space on the earth and heaven and the killers got in".

${ }^{728}$ Salih, M. A. Mohamed "Political Narratives and Identity Formation in Post 1989 Sudan, in Mohamed A. Mohamed Salih and John Markakis (Eds.) (1989) Ethnic and the State in Eastern Africa, Uppsala: Nordiska Afrikan Institutet p. 76.
} 
modern fundamentalism dates back to the nineteenth-century conservative Christians who rejected the proposition of Darwin's evolutionary theory that dismissed supernatural creation. For the fundamentalists, God alone was the Creator of all living beings whereas the Darwinists insisted that life evolved through evolution. ${ }^{729}$ This conflict of ideological theories has continued between the adherents of creationism and evolutionism. ${ }^{730}$

The Creationist view is not in conflict with traditional Islam, which also does not recognise evolution. Instead, many verses in Holy Quran refer to God as the ultimate Creator of the universe. ${ }^{731}$ God is identified as the Organiser of the existing order in the world ${ }^{732}$. The term 'fundamentalism' surfaced in the academic discussion, during the early twentieth-century with the call by the conservative Christians to preserve the fundamentals of their faith. For them, it was a question of contextual beliefs, not a political manifesto to change society and its laws. ${ }^{733}$

Contemporary 'Islamic fundamentalism' is a political ideological discourse that intends to revive strict Islamic traditions of the past and encode them into constitutional systems of states for the territorial citizens. ${ }^{734}$ In this sense, its adherents became known in public institutions of the state as 'Muslim fundamentalists', a group that strives to transform the state through the Islamic cultural identity and rejects the adoption of pluralistic ethnic territorial nationalism. Their aim is the establishment of a 'just' Islamic 'order'. According to Kelsay, Islamic fundamentalism was a reaction to secular rule in Muslim countries. ${ }^{735}$ This discourse conforms to the statements of some interviewed Muslim students. Their values focus mainly on Sharia and the Sunna. They say "We are Muslims and we must revive our Sunna and Quran of our religion in our political

\footnotetext{
${ }^{729}$ Moore, James "The Creationist Cosmos of Protestant Fundamentalism” in Martin E Marty and R Scott Appleby (eds.) (1993). Fundamentalism and the Society Declaiming the Sciences, the Family, and Education, Chicago: the University of Chicago Press. The conservative Christians refer the creationists to the Holy Bible "In the beginning God created the heaven and the earth" (Genesis 1).

${ }^{730}$ Beeman, William O (2001) "Fundamentalism Origins. Fighting the Good Fight: Fundamentalism and Religious Revival” in J MacClancy (ed.) Anthropology for the Real World, Chicago: University of Chicago Press p. 12.

${ }^{731}$ Holy Quran: "He it is who hath created for you all that is on earth" (Surra 2:29).

${ }^{732}$ Holy Quran: "Are you the harder to create, or is the heaven that He built? He raised the height thereof and ordered it; and He has made dark the night thereof, and he brought forth the morn thereof. He spread out the earth" (surra 79: 2730).

${ }^{733}$ Moore, op.cit., p. 45.

734 Obeyesekere, Gananath, "Buddhism, Nationhood, and cultural Identity: A Question of Fundamentals" in Marty Martin E and R Scott Appleby (eds.) (1995). The Fundamentalism Project Volume Five, Chicago: University of Chicago Press, p. 231. The Iranian Muslims' Revolution took power in 1978- 1979 and urged the Muslim nations to revived strict Islamic law in political institutions of states. It constituted a constitution of the Islamic state based in its entirety on the laws derived from the Sharia.

${ }^{735}$ Kelsay, John (2003), op. cit., p. 3
} 
institutions". 736 "In the Islamic institutions, Sharia guides the life of every Muslim and we need its application as a law in Sudan". ${ }^{737}$ In that sense, another one states: "Citizens of Sudan would only be good ones, when they revive the sanctity of Sharia as the guiding order of Sudanese society". 738

The complete revival of the contents of the Quran and Sunna into the modern diversity of Sudan is what Yusuf Kuwa Makki, a Muslim Nuba politician and a former Governor of the SPLM in Nuba Mountains defines as "Islamic fundamentalism". ${ }^{739}$ Makki argues that he was about to adopt it to himself, during his primary school time. ${ }^{740}$ Such a definition by a Sudanese Muslim politician ${ }^{741}$ is very significant for the concept of 'Islamic fundamentalism'. For Makki, religion is divisive and it leads to the breaking down of all social, political and cultural continuity based on tolerance in his home region, the Nuba Mountains. He acknowledges that ethnic and religious composition of the Nuba Mountains is very heterogeneous. It is comprised of Muslims, Christians and Animists and to maintain this diversity is to suspend religion from politics. The Nuba intellectuals organised a conference in Khartoum and pointed out that religion was a very divisive entity and endorsed a resolution that separated it from politics. A secular association, the Komolo, was formed among the Nuba. This organisation was defined as a political movement for the youth of the Nuba, irrespective of faith and moral conscience. ${ }^{742}$

Nonetheless, this research argues that the separation of religion from the constitution of a state does not prevent individual persons from developing 'Islamic fundamentalism'; as Makki states: “I was passionate in my religious classes and the faith in general and would have registered the identity of Islamic fundamentalism" ${ }^{743}$ This statement highlights for us the basis to define a Muslim fundamentalist as an Islamic believer that refuses to suspend the received individual religious homilies and apply them in their basic form without sifting or refining them to suit political, cultural and social institutions.

The practice of Islamic fundamentalism as an ideology that strives to impose Islamic customs and scriptures on public institutions has been in operation in its strict terms, under the current

\footnotetext{
${ }^{736}$ Aza Ali Sheeb, a Ja'alei, University of Khartoum.

${ }^{737}$ Sabah Mohammad, a Shaiqqiyyia, Omdurman Ahlia University.

${ }^{738}$ Tajani Al-Gurshi Muhammed, a Danagella, University of Khartoum.

${ }^{739}$ African News Interviews, op. cit., Yusuf Kuwa Makki, a Muslim political scholar and Governor of the former rebellion military organisation, SPLA with its political wing, SPLM, says: "When I was in the primary school I was almost sliding to Islamic fundamentalism”, p. 1.

${ }^{740}$ Yusuf Kuwa Speaks at the interview with Op't Ende (2001), op. cit., p. 4.

${ }^{741}$ Meyer, op .cit., p. 68.

${ }^{742}$ Yusuf Kuwa Speaks to Op’t Ende (2001), op. cit., p. 4.

${ }^{743}$ Yusuf Kuwa, African News op.cit, p. 3.
} 
Government of President Al-Bashir. For instance, Muhammad Abas Muhammad Saeed, Minister for Engineering Affairs in the Upper Nile State, South Sudan, instructs the staff of his Ministry that includes Christians, Muslims and Animists by stating: "Any written paper or application in the State of Upper Nile must carry the Islamic tradition of introduction: 'In the name of God the Merciful, the Compassionate'. Any applicant's document without that introduction would be invalid". ${ }^{744}$

Muhammad as a Muslim is unprepared to suspend some religious obligations, but in opposition to the 'moderates'. 745

In Makki's view, moderate Muslims are dominant among the indigenous people of the Nuba Mountains region. Nuba Animists, Muslims and Christians consider traditional beliefs of ' $k u j u r$ ', forms of African religious rituals as important parts of their religious life. Animists, Christians and Muslims of the Nuba perform them in open spaces. Christians and Muslims who are not party to these beliefs do not take part in them, but watch them without interrupting or banning them. ${ }^{746}$ The question, "Is religion important and what is your concept about the world in accordance to your religion, does it allow space for other religion(s), if so, please explain?" One Muslim student answered it by noting that: "I see the world as a composition of unexplainable powers and this shows that God is in every religion" ${ }^{747}$ This view conforms to the opinion of two Indian Islamic scholars, Shah Waliyullah and Maulana Abul Kalam Azad. According to Aziz, both scholars declare that God has unified the religions in Quran at the verse that states: "And We have revealed to thee the Book with the truth, verifying that which is before it of the Book and a guardian over it" (Quran 5: 48). Aziz concludes that these scholars describe this Quran verse as a reference to the unity of universal religions. Individual religious communities may differ in accordance to the laws of worship, but their essence as religions is one. ${ }^{748}$

\subsubsection{Imposition of Sharia}

Answers to the question, what are the fundamental duties of the faithful ones in your religion and is there any division of roles in terms of gender makes some Muslim students to attach Sharia as one of the Islamic objectives for a Muslim in social, political institutions as they present their views as:

\footnotetext{
${ }^{744}$ Ray Aam (2004 December 2). "Wazir Shuhoon Handessia fil Ali al-Nil" "Engineering Affairs Minister in Upper Nile Muhammad Abas Muhammad Saeed Speaks”, Arabic Newspaper, Ray Aam, p. 2.

${ }^{745}$ Ingpen, Robert and Wilkinson, Philip (1994). A Celebration of Customs and Rituals of the World, Surrey: Dragon's World Ltd, pp. 6-7.

${ }^{746}$ Yusuf Kuwa Makki at interview by Op t' Ende 2001 p. 4.

${ }^{747}$ Yuosif Ismail Adam, Fur, University of Khartoum.

${ }^{748}$ Aziz, Zahid (2007). Islam Peace and Tolerance, Middlesex Ahmadiyya Anjuman Lahore Publications, p. 15-7.
} 
"It is not enough for the Muslims in Sudan to articulate ... that we are the Muslim majority. It is true that we are majority, but we should ... be committed all to the higher law that is Sharia and codify it into territorial constitutions. ${ }^{749}$ Another continues "Because, religion, Islam obligates its faithful Muslims to apply a just system". ${ }^{750}$ And in the opinion of another, "There is no any other just order in social structures in Sunni interpretation, than the Sharia as Quran requires". ${ }^{751}$ One student concludes; therefore, Sharia must be the source of our constitution". ${ }^{752}$

The majority of Muslims in Sudan belong to the Sunni Islamic order. ${ }^{753}$ For this reason, we could assume that the student might be from Sunni as his answer to the same question carries some similar religious statements such as: "In Sudan, many of us are Sunni Muslims and we must ... apply in our lives the dictation of God that states: 'show us the straight path the path of those whom you have favoured, not the path of those who earn your wrath nor of those who go astray'. The Sunni associate Sharia with al-figh (jurist prudence), in regard to this verse. And it is an obligatory call of God to apply the 'just judgment' and there is no law which is just beyond the Sharia". ${ }^{754}$

These similar invocations for the application of Sharia with reference to the term 'just' define the religious identity of the two students above as Sunnis. It was this verse which the former President, Nimeiri considered on 8 of September 1983 and issued a decree that elevated Islam above other religions in Sudan as the source of criminal and civil laws in Sudan. The decree defined Sharia to "be the sole guiding force behind the law of the Sudan" and judges at different courts throughout the country were instructed to apply the sets of the new Islamic legal code. ${ }^{755}$

One Muslim student interprets the application of Sharia by Nimeiri in his own way and argues: "It is a duty of a faithful Muslim to observe and implement Sharia in daily life, but Nimeiri was an atheist and hypocrite and for this, he had failed to apply Sharia in the right way and now, an Islamic constitution is applied in its authentic procedure and this is what we want, we the Muslims of Sudan". ${ }^{756}$ This claim of the Kababish Muslim student that dismisses the method of Nimeiri of

\footnotetext{
${ }_{749}^{749}$ Maha Nimeiri, Danagella, Omdurman Ahlia University.

${ }^{750}$ Babker Al-Nahar, Ja'alei, University of Khartoum.

${ }^{751}$ Abu Gasim Muhammed, Ja'alei University of Khartoum.

${ }^{752}$ Musa Muhammad Hashim, Ta'asha, University of Khartoum.

${ }^{753}$ Warburg, p. 26.

${ }^{754}$ Anor Hassib Allah, a Misseiriyyia Arab, University of Khartoum.

${ }^{755}$ Fluehr-Lobban, Carolyn (1985). Islamic Law and Society in the Sudan, London: Frank Cass, p. 280.

${ }^{756}$ Nuwal Husseni Abdullah, a Muslim Arab Northern Kordofan state from Kababish Arab.
} 
applying Sharia in Sudan needs to be scrutinised. How Sharia could be applied correctly and why does he think that Nimeiri was an 'atheist'?

First, Sharia is a divine system that regulates the method of worship, performance of rite and conduct of Muslims. ${ }^{757}$ Yes, there is no uniformity of its application. Muslims in different countries follow different schools of Sharia. For instance, the former Ottoman states in the Middle East adhere today to the school of Hanafi doctrine. Abu Hanafi was the founder of this legal sect and theorised ray (opinion) and istihsän (jurist preference) as main method of applying Sharia in the courts. This is not applicable to the Muslim countries of North Africa, where the Maliki School of Sharia operates. Malik Ibn Anas adopted the practical Islamic religious relationships that existed among the earliest Muslim community at Medinna. He considered these religious precepts as genuine sources of Islamic precedent and referential ones of Sunna. The Hanbali School of Sharia is adopted in Saudi Arabia and was founded by Ahmed Ibn Hannibal. This school observes Hadith (acts and sayings of the prophet) and Islamic traditions as the basic sources, on which the Sharia relies. Malaysia and Indonesia practice the doctrine of Shafi'i. The founder of this school was Muhammad Ibn Idris al-Shafi'i. He systematised some Islamic theories which reflect similarities with the Maliki School and legalised them. ${ }^{758}$ What unifies these schools is Holy Quran, but they differ in methodology and theoretical legal process. ${ }^{759}$

Therefore, the presence of five schools with their different methodological approaches disqualifies the claim of the student that Nimeiri had applied Sharia incorrectly. It would have been better, if there was a unified method of Sharia, but since each school follows its methodology and theories, then it would be a misleading for any Muslim in Sudan to blame Nimeiri over the methodological application. An-Na'im observes that the application of Sharia law in the judiciary of Sudan carries serious contradictions, since there is so much diversity of opinion among Islamic schools of thoughts and scholars. Hence, its enactment of its principles as legal laws is only based on the selection of some opinions over others, thereby denying believers the freedom of choice among equally legitimate competing opinions. Moreover, there is neither a paradigm of precedent

\footnotetext{
${ }^{757}$ Lunde, Paul (2002). Islam, Faith, Culture History, London: Dorling Kindersley Limited, p. 23.

${ }^{758}$ Brown, Daniel (2004). A New Introduction to Islam, Oxford: Blackwell Publishing Ltd, pp. 120-121.

${ }^{759}$ Leblanc, p. 485.
} 
of an Islamic state to be followed, nor such state practically viable today with exception of the Prophet in Medinna as to be useful and adopted today. ${ }^{760}$

The second issue is the description of Nimeiri as an 'atheist'. This was not uncommon allegation, taking into consideration his common life within the social structures of Sudan. The private life of Nimeiri included experiences that contradicted Islamic religious obligatory norms. Lesch reiterates that, after Nimeiri's imposition of Sharia, some Sudanese were astonished, and mostly his ministers who used to drink with him suspected his religiosity. They accused him of having advocated an Islamic hard line and stopped them from consumption of alcohol as an alternative to his doctor's advice to cease drinking, after the operation on his heart. In response to this allegation, Nimeiri denied and gave two reasons for the imposition of Sharia. First, in his opinion, the country was backward economically and Sharia would change the people from bad Sudanese in deeds to virtuous Sudanese Muslims. According to him, good Muslims would only look after consolidation and solidification of socio-economy without practicing bad activities such as drinking. Second, Sharia would create a unified national identity of the Sudanese as followers of the Islamic cultural way. $^{761}$

\subsubsection{Religious Puritanism and economies}

According to some Muslim students, Sharia is a divine legal source that opens economic prosperity for an Islamic nation. ${ }^{762}$ One of them concludes that: "The economic success of Christians, especially the Calvinist sect in Western Europe was a result of their commitment to their religion, Christianity and its culture. For this reason, Nimeiri imposed ... Sharia to the national institutions of Sudan, so that God could help him in improving the economy of the country". 763

In fact, President Nimeiri thought that the application of Sharia would improve socio-economic and insure prosperity and success in his local economy. According to Lesch, President Nimeiri argued that immoral bad deeds of the people of Sudan had caused failure in achieving economic success; hence, the implementation of the strict religious laws derived from Sharia would revive economic success. ${ }^{764}$ The teaching literature of the Calvinist Protestant theory attributes the success

\footnotetext{
${ }^{760}$ An’Naim, Abdullahi Ahmed (Summer 2003). "Re-affirming Secularism for Islamic Society", New Perspective Quarterly, pp. 1, 11.

${ }^{761}$ Lesch op.cit., p. 54

${ }^{762}$ Ibrahim Abdulla Ali, University of Khartoum, Al-Nur al-Sadiq, University of Khartoum.

${ }^{763}$ Ahmed al-Taj, a Shaiqqyyia, University of Khartoum.

${ }^{764}$ Lesch, Ann Mosley (1998) The Sudan Contested National Identities, Oxford: James Currey, p. 54
} 
of the capitalists in the Western European societies to the religious Christian 'Puritanism' of Calvinists. This religious movement carries out its religious and ideological ethic that is based on regular conscientious work. The Puritans unanimously believe that God has predestined them, either salvation to heaven or hell as damnation and nothing they could do to change the predetermined destiny only a minority would enter into heaven. Hence, it is incumbent upon the believers to refrain from hedonism and commit themselves to religious practices which represent the glorification of God. Under this teaching, the Calvinists avoid spending profit on pleasures, rather than investments. The Calvinists interpret the economic prosperity in the Western European institutions as a symbolic success of the world. In their conceptual belief, such success represents them as the chosen faithful group to enter into paradise. ${ }^{765}$

The claim of the Muslim student that Nimeiri imposed Sharia as a result of imitating the European Christians was flawed for three reasons. The European traditional commercial method was not entirely based on Puritans' economic conservative view; it involved irreligious practices of pirates and other haphazard methods of acquiring wealth. Second, European merchants have been effectively involved in disposing of their money in expensive centres of social recreations consuming alcohol and other foods and drinks. ${ }^{766}$

Third, the economic procedures of the capitalist West do not conform to the economic procedures of Islamic states, where laws are derived from the Sharia. The regulated economic mechanism of the Islamic systems shows the economic discrepancies in their economic policy structure. In reference to An'Naim, Pakistan, Sudan and Iran apply Sharia in their economic regulations, thus, their economic organs refrain from adopting interest in commercial dealings. ${ }^{767}$ Commercial transactions of the Sharia reject interest in its institutional economic system ${ }^{768}$, while interest is the objective of the capitalist Western European entrepreneurs in all their economic institutions. ${ }^{769}$

In the view of some Muslim students, Nimeiri acted abruptly without sufficient economic means for applying Sharia. ${ }^{770}$ Islamic states need to secure appropriate economic sufficiency, where each person owns some economic income and a work place within the institutions of the state. ${ }^{771}$

\footnotetext{
${ }^{765}$ Weber, Max (1958). The Protestant Ethic and Spirit of Capitalism, New York, Scribner's p. 236

${ }^{766}$ Weber, Max (1963) .The Sociology of Religion, Boston: Beacon Press, p. 179

${ }^{767}$ An-Na'im, Abdullahi Ahmed (1992). Human Rights in Cross Cultural Perspective, Quest for Consensus, Philadelphia: University of Pennsylvania, p. 34

${ }^{768}$ Lesch, op. cit., p. 56.

${ }^{769}$ Weber (1958), op. cit., p. 170.

${ }^{770}$ Asma Eiz al-Din, el-Gezira Musalimiyyia, Omdurman Ahlia University.

${ }^{771}$ Mariam Hassen Rajeb, Hawazama, University of Juba.
} 
According to Simone, theoretically, Sharia forbids black markets and currency speculation and hoarding; however, he states that the members of the NIF party that applied this Sharia "have grown through these very practices, merchants who finance the NIF are highly dependent on the second market". ${ }^{772}$ Simone concludes that, after the introduction of Sharia, crime increased, as drug dealers and alcohol brewing became major sources of economic income and survival. ${ }^{773}$

The research argues that President Nimeiri has not heeded the practical situation of Sudan that qualifies it to the category of Sharia. A state without the 'means of some change is also without the means' that constitutes the revival of religious and cultural conservative. ${ }^{774}$ According to An'Naim, Sharia obliges an authority of an Islamic state to ensure social and economic standards for its citizens as a prerequisite for its strict application ${ }^{775}$. Nimeiri ignored this prerequisite; meanwhile, the socio-economy of Sudan, during that time had deteriorated to the extreme. The Gross Domestic Product (GDP) had shrunk to 3.6 percent with heavy accumulation of foreign debt, devalued Sudanese pound currency, high prices of food items and gasoline for the people of Sudan. ${ }^{776}$

This situation stimulates us to argue that the prevailing economic shortage, during those days implied having no means for the adoption of Islamic religious orthodoxy in such poor economic and social institutions. If absolutely necessary, the economic prosperity would have been first improved prior to the imposition of Sharia and followed by institutionalisation of Islamic religious orthodoxy with the aim to build a conservative society, in the due course of time. Yet it should exclude hudud, since it amounts to torture, cruel, inhuman and degrading treatment and punishment. ${ }^{777}$ Acting contrary to this theory and imposing the adoption of Sharia without an economic change in the prosperity of the people in Sudan and observation of human rights has caused resistance, even from the leader of the Islamic religious and ethnic Arabs. According to Daly, during the imposition of the Sharia in national institutions of Sudan, the head of the Islamic religious sect, Ansar, Sadiq AlMahdi reacted and argued "how could there be an amputation for a poor man forced by the

\footnotetext{
${ }^{772}$ Simone, op. cit., p. 33.

${ }^{773}$ Ibid.

774 Rochon, Thomas (1998). Culture Moves, London: Princeton University Press, p. 3.

775 An-Naim (992), op. cit., p. 34.

${ }^{776}$ Lesch, op. cit., p. 53.

${ }^{777}$ International Covenant on Civil and Political Rights Adopted and opened for signature, ratification and accession by General Assembly resolution 2200A (XX1) of 16 December 1966, entry into force 23 March 1976, in accordance with Article 49. Article 7 of this convention states: "No one shall be subjected to torture or cruel, inhuman or degrading treatment or punishment"
} 
circumstance to steal and feed his own family". ${ }^{778}$ Daly concludes that Al- Mahdi did not reject its essence as a law, but because of the prevailing political and economic impoverishment in the environment of Sudan. ${ }^{779}$

Yet, the study disagrees with Sadiq al-Mahdi on his promotion of the application of Sharia, if the economic situation improves in Sudan without denouncing the hudud penalty. A faithful Muslim negotiates with God to eliminate a culture that is not suitable for human nature. God is a living One that listens and heeds attentively to the petitions and concerns of the faithful people and evaluates them and offers a 'gradable' law to the nature of human being. According to Horrie and Chippindale, God instructed the Prophet Muhammad from heaven through Musa to promulgate to the followers of Islam that prayer must be conducted fifty times a day. Muhammad realised that fifty sessions per day devoted for prayer was too much for the culture of human nature. The Prophet introduced negotiation with God through Musa explaining the burden of prayer fifty times per day to the faithful Muslims. In the end, God was receptive to the concerns of the Prophet and allowed him to inform the Muslims to pray five times a day, instead of fifty times. ${ }^{780}$ In the view of the Sudanese Lawyer, Ali Mahmoud Hassanien, hudud, (flogging and amputation of human cross limbs) in Sudan amounts to torture, because, by definition, torture, "includes severe pain or psychological suffering". 781

\subsubsection{Arguments on the hudud punishment}

Students express their views and opinions over the introduction of the Sharia in Sudan at different responses to the question: "What are the duties of faithful ones in your religion and the roles of women?" Some Muslim students say that it is their duty as faithful Muslims to establish a just Islamic society that could only be achieved by applying the Sharia ${ }^{782}$. One of them concludes that: "Application of Sharia is a must in order to fight all forms of corruption on the land". ${ }^{783}$ Islamic law states that "The only reward of those who make war upon God and His Messenger and strive, after

\footnotetext{
${ }^{778}$ Daly (1986), op. cit., p. 148.

${ }^{779}$ Ibid.

${ }^{780}$ Horrie, Chris and Chippindale, Peter (1997). What Is Islam a Comprehensive Introductory, London: Virgin books, p. 1.

${ }^{781}$ Hassanien, Ali Mahmoud (2006, May). General Comments on Proposed Interim Constitution of Sudan, Mahawir, Journal for the Sudanese Studies, Issue No. 13, p. 34.

${ }^{782}$ Madina Abdel Baqi, Misseiriyyia Omdurman Ahlia University, a good Muslim adheres to the Sharia. This is why it is a duty of every Muslim to apply the (sic) Sharia to build a just family. It is our public duty to apply Sharia, as a process of grooming a good society.

${ }^{783}$ Sumia Ali Mohammad, University of Khartoum.
} 
corruption in the land will be killed or crucified, or have their hands and feet on alternate sides cut off'. 784

Fighting 'all forms of corruption' in the universe in an Islamic way, include detention, flogging and amputation of human cross limbs in Sudan. In reaction to this kind of system, a 'Christian Animist' student argues: "Nimeiri introduced a system that hunts for people to fill the prisons with those who are conscious of themselves, but the current regime allege them of having drunk beverages and makes them ... hostages, under the detention within its dirty cells". ${ }^{785}$ According to Lesch, detention and hudud that includes the amputation of human limbs and flogging of people escalated in Sudan, after the adoption of the Sharia in the judiciary. Public police are armed and instructed to move from house to a house in search of alcohol. A large number of men are whipped every day in different courts of Khartoum, under the accusation of having drunk liquor. The public prison is filled every day as, during the first days of its introduction, two young men were amputated and an adulterous was hung and a thief was killed. ${ }^{786}$

A 'Christian Animist' student describes this phenomenon as 'a choke' and argues that: "Sharia, a law that prevents freedom to take alcohol raises serious questions on the control of our cultural characters and the insertion of such a legal system that chops the limbs of the non-Muslims equally with the Muslims. I was choked and had to leave immediately Khartoum ... after I saw the amputated Sudanese citizens and remained in the areas, under the control of the SPLA and SPLM" ${ }^{787}$

The adoption of the Sharia in national institutions of Sudan might have stimulated a large number of the Christians and the Animists from the South to join the rebellion, SPLM and SPLA. According to Liben, the Southern Christian, William Ochan Ajjugo from Juba, capital city of South Sudan says that the people of the South were shocked, after the imposition of the Sharia: “... soon I began seeing the results people with arms and legs cut off for violating the Sharia; I was dissatisfied that Khartoum was a land of killers and I went to the South, where the forces of the SPLA operated". 788

\footnotetext{
${ }^{784}$ Holy Quran (Surra 5:33).

${ }^{785}$ B K, a Dinka Christian Animist, University of Juba.

${ }^{786}$ Lesch, op. cit., 55.

${ }^{787}$ Emanuel Gai, a Dinka, University of Bahr el-Ghazal.

${ }^{788}$ Liben, Paul H (1995, August-September). "Murder in Sudan", First Things, Vol. 55, p. 42-44, htt://www.leaderu.com/ftissues/ft9508/liben.html.
} 
After the imposition of the Sharia, John Garang with his political and military organisations, SPLM and SPLA escalated the fighting against the Nimeiri system that applied hudud. At this time, Garang became a charismatic popular leader with his determining visionary goals among the Christians, Animists and marginal Muslims at the peripheries. Some students of Muslims, and Animists of South Sudan, Nuba Mountains and Ingessana Hill claim that: "After the imposition of ... Sharia, there was no hope for our religions and cultures, under severe hudud penalties. We the African marginalised Christians, Muslims and Animists majority in the South, Nuba Mountains and Ingessana Hill thought only of John Garang as an alternative to Nimeiri regime". ${ }^{789}$ Another said "Garang rejects the eradication of our cultures and represents a radically different vision against Nimeiri by defining off diametrically the status quo of Islamic hudud. He captures ... our hearts and our minds and became our public saviour from the imposed vision of monolithic, religious intolerance of Islamising and Arabising us and killing us with harsh hudud". ${ }^{790}$ Further, another one added: "Because of Garang, Nimeiri failed to create an exclusive political Islamic nation based on suppressing Christianity and Animism and inserting the law that chops people. ${ }^{791}$ Akot Kuot concludes that Nimeiri considered the followers of these religions as his major dissidents and removing them might relieve him in turn, these followers would embrace Islam or become second class citizens in their own natural land. ${ }^{792}$ According to Sidhamed and Ehteshami, the radical Islamists in Sudan have desperately encoded the Sharia, under the claim of establishing a just social order in the country. This form of law in Sudan applies hudud, an Islamic penalty that settles different forms of crimes. Under hudud in Sudan, cross limbs of thieves are amputated, women proven guilty of adultery are flogged, including all men and women found guilty of drinking alcohol and beverages must also experience flagellation in a criminal court of the Sharia. While the married women confirmed of having committed adultery are penalised by stoning them to death. ${ }^{793}$ Currently, this law is still being applied in the jurisdiction of the political North of Sudan. One question that asks: "What are practices in your religion regarded as indecent or immoral, in which a

\footnotetext{
${ }^{789}$ Lul Juk, a Nuer Christian Animist, University of Upper Nile: "Nimeiri imposed Sharia and there were no more traditions and cultures of Africa in Nuba Mountains and Ingessana Hills, but John Garang was our hope".

${ }^{790}$ Akoc Mamier, a Dinka, Juba University: "Nimeiri wanted to wipe away our cultures and imposed Islam on us, but Garang placed a radical line against his Islam".

${ }^{791}$ Madut Deng Ater, a Dinka, University Bahr el-Ghazal: "Nimeiri wanted to suppress Christianity and Animism and put Islam on us, but Garang rescued us".

${ }^{792}$ Akot Kuot Mel, a Dinka, University of Juba "Nimeiri saw the people of the South as a collective threat to his regime, so he chose to Islamise them and killed those who rejected it and the rest would remain as second- class citizens.

${ }^{793}$ Sidahmed, Abdel Salam and Ehteshami, Anourshiravan (eds.) (1996). Islamic Fundamentalism, Oxford: Westview Press., p. 179.
} 
violator must be sentenced and do you think such practices are manifested at your university campus and any other place in Sudan?" One Muslim student at University of Khartoum rejects the penalty of hudud, under the circumstance that: "It is an uncivilised law that ... contravenes the regulation of the world civilisation. For me, the best system that suits our country is secular democratic pluralism". ${ }^{794}$ Another concludes: "Sharia builds an abnormal society by cutting their hands and their legs. We have an abnormal boy, Mohammad Hassan Hamdan in Darfur. He was not ... born abnormal, but the current regime of Omer Hassan Al-Bashir in power amputated his right hand and left foot in 2003, when he was sixteen years old. Hamdan has become a burden on us now. So, Sharia should be abolished and go for all, since it abnormalises the citizens". ${ }^{795}$ Amnesty International, and the Sudanese Human Rights Agency based in the United Kingdom (UK) Sudan Victims of Torture Group (SVTG) released an urgent appeal on 23 January 2001, urging the Government of Sudan to suspend the amputation of Ibrahim Gumai, Omer Salim, Salih Omer, Abakar Jalab and Dafa Alla Mowloudi from the indigenous ethnic groups of Darfur. On Thursday 25 January and Saturday 27 January 2001, the right hands and the left legs of these five men were amputated. ${ }^{796}$ In 2003, the Sharia court in Nyala, a town in Southern Darfur convicted four men from the indigenous ethnic group of Darfur after being alleged of highway armed robbery at the town of Dhein, south of Nyala. Their right hands and left legs were amputated. ${ }^{797}$

The amputation of limbs is a routine and consistent practice as the author visits these victims of amputation, but what is not answered is the sordid situation of the victims as power in state does not offer alternative measures to alleviate the hardship of life they experience as handicaps. Some Dinka Christian-Animists describe the hudud penalty that amputates the human limbs as abnormal law as one argues: "Under Sharia, my Christian relative, Deng Ngot Riny was about to experience abnormal punishment of amputation to his ... limbs in Port Sudan ${ }^{798}$. Another concludes: “This

\footnotetext{
${ }^{794}$ M A, University of Khartoum.

${ }^{795}$ S A A, a Zagahwa, University of Khartoum.

${ }^{796}$ Amnesty International and SVTG (2001, February 23). "Medical Letter Writing Action, Fear of Amputation for 19 Men, Sudan, AI Index: AFR 54/005/2001Distrib: PG/SC http:www.asiapacific.amnesty.org/library/Index/ENGAFR540052001?open\&ofENG-2AF.

${ }^{797}$ Akhbar al-Youm (2004, April). "Araba men Nheb al-Musalla Yawajahhoon al-Hokim bel Gatha Athahom fil Goreb al-Sudan Darfur", p. 2, Arabic Newspaper, Akhbar al-Youm: "Four Armed Robbers Face Amputation in Sudan's Western Darfur". http://www.arabic-radio.tv/newspapers/sudan/akhbaralyoum.htm.

${ }^{798}$ Thuc T Giir, University of Juba.
} 
abnormal practice is the way the Muslim Arabs in power think they could convert us to Islam ... a religious law that transforms us to become abnormal ones is not ours". 799

The description of Sharia as an 'abnormal' law creates more controversies among the students. For instance, a Muslim student from Shukuriya Arab at University of Khartoum does not embrace this description and argues: "Sharia is a God's law; it should be applied without any hesitation and complaint in Sudan". ${ }^{800}$ A Christian Animist from the 'Collo' ethnic group opposes the generalisation of Sharia to include the non-Muslims and argues: "If different 'democratic', 'theocratic' and 'autocratic military' systems that have been in power in Sudan were to take Sharia as the law for the Muslims, it would have been better". On the contrary, another concludes: "The Muslim successive systems control laws of the non-Muslims in the country. They ... strive to constitute Sharia to include the Animists and Christians and in this way ... customs and traditions as sources of our laws are neglected". ${ }^{801}$ Preis argues in protest over the control of social and political leaders to cultures of other people and use their cultures as the measures for addressing social and cultural issues of others. In her view, the rights of people cannot be circumscribed by the standards of a single culture. They should not be dictated by the aspirations of any culture of a single people. ${ }^{802}$

In the opinion of Fur and Nuba Muslim students at University of Khartoum the rights of people should not be measured, under the standard of a single culture. A Fur student notes: "The nonMuslims like the people of the South living in the North should be treated in accordance with their customs as the constitution dictates". ${ }^{803}$ For a Nuba student: "In Sudan, the constitution speaks alone and power in Khartoum speaks differently, but we shall force the power to respect the diversity stipulated in the national constitution. ${ }^{804}$

This writer has noted that non-Muslims are sentenced to flogging by the courts, because of having drunk alcohol and that is a violation of their customary rights encoded in the constitution. It seems customs are not practical within the territorial North of Sharia. Some of the victims of Sharia in

\footnotetext{
${ }^{799}$ Malueth Lueth Mou, a Dinka, Omdurman Ahlia University.

${ }^{800}$ Mohammed Abdel Halim, University of Khartoum

${ }^{801}$ Ajak Muwad, University of Juba.

${ }^{802}$ Preis, Ann-Belinda S (1996, May). "Human Rights as Cultural Practice: An Anthropological Critique", Human Rights Quarterly, Vol. 18, No. 2, p. 286.

${ }^{803}$ Muhammed Al- Haj, a Fur, University of Khartoum.

${ }^{804}$ Shoukri Hussien, a Nuba Muslim, University of Khartoum: “There is no system in Sudan which respects the constitution. We make constitutions which detail the way forward, but our capital city Khartoum interprets them in their favour of assimilation to Muslim Arab culture".
} 
Sudan came from different customs and cultures which would have been used as standard measures for their punishments, but Sharia does not allow. The 'Penal Code' of 1991, article 146 states "Anyone having sex outside marriage shall be punished with execution by stoning." 805 This legal code is applied in Northern Sudan jurisdiction; however, it does not exempt non-Muslims. For instance, in 2004, this single culture of Sharia was imposed on the Dinka woman, Alakor Lual Deng in the town of Nahud in the western Sudan. The court found her guilty of adultery and sentenced her to be stoned to death. After torturous move from human rights organisation, the High Court of Justice upheld her appeal and quashed the sentence in June $2004{ }^{806}$

According to the Dinka students, this penalty is contrary to their customary law that settles cases related to adultery. The questionnaire question, "What is a practice regarded as sinful, indecent or immoral in which a violator must be sentenced, what you think of it and how to deal with believers of other religions violating the same practice in Sudan? A Dinka student at Omdurman Ahlia University answers it as, in Dinka religious customs, rituals are performed in accordance to the nature of a situation which requires a sacrifice. For example, aci khor (adulteress) needs a traditional divine priest to purify her in a religious ceremony, since she is a married woman. It is believed that a married woman that has undergone sexual practice outside apart from her husband has committed a serious act that entails guilt and shame and above all, is a sin. This sin requires reconciliation with God by purifying her spiritually, before she resumes sexual relationship with her legal husband. In addition, the adulterer man pays eight cows to a husband of adulteress. ${ }^{807}$ One Muslim student, however, argues that Sharia comes from an old culture and needs to be revised in order to meet the technical world. In Sharia courts, it is claimed that adultery must be proved by four men who must witness two opposite sexes engaged in sexual intercourse. Our common sense teaches us that it is impossible to witness adultery in the contemporary world of cultural technology, because modern houses of today are not easily accessed like the primitive houses of the medieval ages, where four outsiders could witness adultery. ${ }^{808}$ Another Muslim concludes: "Legislation of Sharia puts the institutions of Sudan on the right dimension of assimilation". ${ }^{809}$

\footnotetext{
${ }^{805}$ Sudan Penal (1991). Sudan Penal Code.

${ }^{806}$ Amnesty International (2005). "What Hope for the Future? Civilians in Urgent Need of Protection", Amnesty International AI Index: AFR54/ 164/ 2004, p. 1.

${ }^{807}$ K K M, Omdurman Ahlia University.

${ }^{808}$ M H Omdurman Ahlia University.

${ }^{809}$ Mohamed Al-Naeem, University of Khartoum.
} 


\subsection{Gradable assimilation}

Some Muslim students at University of Khartoum from Nuba Mountains present their opinions on the best system that fits the religious diversity in Sudan. The first student argues: 'for me, the best system that suits our country is a secular constitution that constructs a gradable assimilation, ${ }^{810}$ Another one defines the 'gradable assimilation' as 'it is a form of an assimilation that does not remove fully the existing religious and ethnic diversity. ${ }^{811}$ One student concludes that the adoption of the 'gradable assimilation' makes it possible for the ethnic Muslim Africans, Animist Africans and Christian Africans to live together in the country with the Muslim Arabs and Christians, where each takes the gradable culture of another'. ${ }^{812}$

The opinions of Muslim students who favour secular system, instead of the Islamic system to be adopted in national institutions of Sudan as a suitable model, because it does not fully assimilate; instead, it allows 'gradable assimilation' urge the search for further definition of assimilation. According to Yinger, assimilation is a process of reducing boundaries that occur, when members of two or more societies, ethnic groups, or smaller social groups interact in political, social and cultural spaces. ${ }^{813}$ In studies of antonyms or opposites, something gradable is referred to as a comparison of identical entity. For instance, the opposite of a long thing is not necessarily something short; it could be medium. ${ }^{814}$ This logical comparison forces the author to acquiesce to the students' claims that secular constitution builds 'a gradable assimilation'. In this way, a gradable assimilation can be defined as a kind of an assimilation that endeavours to reduce cultural boundaries without the imposition of a strict political initiative that eradicates diversity; instead, it creates likeness of cultures and it is not necessary to completely transform them to the dominant culture of majority. In another words, it is an assimilation that seeks gradable methods not necessarily a complete removal of differences between the interacting groups of different cultures, but a typical reproduction of likeness.

The laws inherited from colonialism conformed to the cultural diversity of religious and ethnic structures were constituted and applied in a method that was gradable; however, the imposition of Sharia in national institutions of Sudan has removed the gradable method. According to Hale, the

\footnotetext{
${ }^{810}$ Abdulla Salah.

${ }^{811}$ Wamimma Al-Tom.

${ }^{812}$ Muna Mugtar Ahmed.

${ }^{813}$ Yinger, op. cit., p. 38.

${ }^{814}$ Fromkin, Victoria and Rodman, Robert (1993). An Introduction to Language (5 ${ }^{\text {th }}$ ed.), Philadelphia: Harcourt Brace College Publishers., p.132.
} 
British had two forms of law in Sudan: first, the secular laws dealing inclusively with civil cases and individual non-Muslims and consenting Muslims; secondly, there were courts of the Sharia which settled personal cases for Muslims and consenting non-Muslims. Under the Sharia, secular laws are dysfunctional. ${ }^{815}$

\subsubsection{Language}

The issue of an official language in national institutions in Sudan is controversial among the students of the higher education in Sudan. Instances of this controversy begin as: "I am a Fur; I want my cultural identity to be connected with my language. The successive governments in Sudan control the flow of other tongues to be in national institutions constitutionally". ${ }^{816}$ Other states: "We try to revive the Nubian language, but leaders are Arabs, so they adopt Arabic as an official language in our schools and prevent speaking in the Mahas language". ${ }^{817}$ Another student argues: "Those whose their languages are rejected in national institutions and struggle to revive them are derogatorily described by Muslim Arab leaders as the 'lost brothers"" ${ }^{818}$ One student concludes: "The reason for the description of those who speak in their languages as 'lost brothers' is to control these languages to accelerate assimilation to Arab identity. With all these political initiatives of the control, the indigenous Africans of Darfur, Nuba Mountains, Ingessana Hill and Beja are not fully assimilated. We still express our arts and music in our languages .... We live with Arabs, yet we remain different in classical music. ${ }^{819}$ According to Sharkey at the decolonisation of Sudan, the Arab Muslim nationalists turned ta'rib (Arabisation) into an official state policy that sought to propagate Arabic quickly throughout a territory where scores of different languages were spoken. ${ }^{820}$

This author argues that social interactions of social group in national institutions or between neighbours creates a new culture perhaps not instituted or imposed politically, but functions within the intensity of language cultural contacts. In this sense, a gradable assimilation based on each cultural language expression in performances of music and arts may be reflected from another cultural performance of a neighbour social society and when that functions within different

\footnotetext{
${ }^{815}$ Hale, Sondra (1997). Gender Politics in Sudan, Islamism, Socialism, and the State, Boulder: Westview Press, a Division of HarperCollins Publishers, Inc., p. 137.

${ }^{816}$ Seisi Gasim Adam, University of Juba.

${ }^{817}$ A A H, University of Khartoum.

${ }^{818}$ Ali Sabor, University of Khartoum.

${ }^{819}$ Gira Adam, a Nuba Muslim at University of Juba.

${ }^{820}$ Sharkey, Heather J. (2008, December 18). "Arab Identity and Ideology in Sudan: The Politics of Language, Ethnicity, and Race, African Affairs, the Royal African Society, Vol. 107, No. 426, p. 21.
} 
language community, then such a society lives in a political environment of 'gradable assimilation' of languages. At this moment a state could promote them in their respected institutions, while the widely spoken language(s) at the status of advanced science could be agreed politically and taken as a language of instruction in national institutions without prejudice to other remaining languages. According to Daly, during British colonialism, Secretary for Education and Health, J G Mathew organised a conference called the 'Rejaf Language Conference' in April 1928 at the village Rejaf in the former provincial territory, Mangalla in the Southern Sudan. ${ }^{821}$

The issues for the discussion at the conference were, first, the drawing up of a classified list of languages among the ethnic groups of the South and second, to conduct deliberations, whether it was possible to open up boundaries of some ethnic languages to be adopted for educational curriculum and if so, what languages deserved to be selected among the languages of the various ethnic groups in the South without prejudice to the other languages of the cultural minorities? ${ }^{822} \mathrm{~A}$ third goal was to discuss and propose a unified system of orthography in the South, while fourth, they were to make proposals for co-operation in the production of text books and the adoption of a skeleton grammar, reading books and primers for general use. The delegates selected six languages, under the category that they were widely spoken by the majority and suitable for development and the rest would remain as potential ones within different communities to be developed. The chosen languages were: the Dinka, Nuer, Shilluk, Azande, Bari and Latuko. ${ }^{823}$ These languages were applied to the beginners of primary schools, along with English at other extensive levels of learning. The languages maintained possible reciprocity with each other without conflict. ${ }^{824}$

The turning point of the conflict based on language identity in Sudan came after the shifting of power in Sudan to eradicate this 'gradable assimilation' that emerged, after the imposition of structural change of educational curriculum in the South. Reference to Lesch, the educational system in accordance to the Rejaf linguistic conference of 1928 allowed the South to operate in its local languages and English. During the preparation for independence, the ruling Muslim Arabs at the transitional tenure eradicated these languages from the curriculum of education in the South.

\footnotetext{
${ }^{821}$ Daly, Martin W (1986). Empire on the Nile: The Angelo Egyptian Sudan 1899-1934, Cambridge: Cambridge University Press, p. 171.

${ }^{822}$ See the Report of the Conference (1928). "Report of the Rejaf Language Conference", Sudan Government Wellington House, Buckingham Gates, S W 1, Education Department, Khartoum, and International Institute of African Languages and Cultures, 22, Craven Street, London, WC 2, pp. 3-5.

823 Ibid.

${ }^{824}$ Northey, W Brook and Morris, C J (1929). Report of the Rejaf Language Conference, 1928, Bulletin of the School of Oriental and African Studies, Vol. 5, pp. 2-3.
} 
The reason for this plan was to create a unified educational system, under the control of the state. In the South the subsidised missionary schools came under scrutiny. A report in 1954 by an 'International Commission on Secondary Education' had advocated the transfer of the missionary schools to government control and replacement of English and other languages with Arabic as the only language of instruction. Such a policy was insensitive to the traditional African people of the South who unanimously rejected it. In 1957, the government proclaimed its decision to nationalise the system of education into Arabic in all the schools within the territorial state. Forceful measures were taken with the aggressive policies to impose Arabisation of education, instead of the languages of the South and English. Lesch concludes that six intermediate Islamic institutes were opened in the South and Christian missionaries were barred from opening any more schools. ${ }^{825}$ Muhlhäusler observes that power sometimes introduces some measures of control to the use of some ethnic minority languages in a state. It could label them in a derogatory way as useless and lacking appropriate syntactic structures and eliminate them from the academic curriculum through legal measures. $^{826}$

The approach of power that favours Arabic above local languages including English as the only language of education in Sudan contradicts the thoughts of the subordinate people of the South. These people hold their ethnic languages as worthy of maintenance in educational curriculum. English for them is more appreciated than Arabic claiming that is disconnected from Arab culture. These sentiments are reflected in the statements of the majority students who argue that it is not necessary to adopt the Arabic language for the operation of institutions. ${ }^{827}$ English and all other African languages could constitutionally co-exist with it. ${ }^{828}$ One of them concludes that 'unfortunately', those Muslim Arabs in power regard Arabic as 'their blessed language and the rest are the languages of the pagan tongues' ${ }^{829}$ Idris observes that the successive rulers of Muslim Arabs in Sudan describe Arab identity as flexible in uniting the people of Sudan. They swiftly articulate this model by generalising the definition of an Arab identity. For them an Arab national is referred to as any one that communicates in Arabic and adopts an Arab name. Idris concludes that

\footnotetext{
${ }^{825}$ Lesch, op. cit., p.34.

${ }^{826}$ Muhlhäusler, Peter (1986). Pidginand Creol Linguistics, Oxford, Basil Blackwell, p. 22.

${ }^{827}$ Akuei Lual Ater, a Dinka, University of Bahr el-Ghazal.

${ }^{828}$ Emilo Lwang, a "Collo" ethnic group, University of Upper Nile.

${ }^{829}$ Padeit Awang, a "Collo", University of Upper Nile.
} 
Muslim Arabs think that such adoption provides an open culture of unifying mechanism for the simple national identity, Arab, than an African one. ${ }^{830}$

The imposition of a language or any cultural identity beyond 'gradable assimilation' to another unique culturally group creates a new general evaluation to such a system. Those affected evaluate it and seek alternatives in many ways, including violence against the state. We have an instance of this claim in Sudan, where English has been the language of instruction at the University of Khartoum. Abruptly, the structural shift of the state for inserting Arab identity based on Arabising institutions included this university into the scale of changing the system into Arabic that is intertwined with religious classes to the non-Muslims. This shift has caused some Christians and Animists of the South to drop out from Universities in Sudan. Some of the affected group chose to march into the bush and became members of the SPLA fighting against the central government. Kane explains that young Christian men and women of the South Sudan became disadvantaged, after the introduction of the Sharia in Sudan at learning higher institutions, including University of Khartoum, where the Faculty of Law imposed new measures that forced non-Muslims to study Sharia in Arabic. This situation dissatisfied the Christians and the Animists of the South and moved to the organisation revolutionary movement, the SPLA. Aleu Akechchak Jok, a Catholic Christian from the largest ethnic group in the South, the Dinka was among the group affected by the Arabisation at the University of Khartoum. Aleu argues: "Me as a Christian how do I become a Sharia student studying in Arabic". 831

The African Christian Animist people of the South prefer English, rather than Arabic, while both languages are aliens to them. According to Collins and Deng, the Christian Animist population in Southern Sudan regarded the British colonisers, during their first interaction as other invaders who would undoubtly attempt to suppress their independence and exploit their human and natural resources. For the first twenty-five years of British rule in Southern Sudan the district officials spoke English or an African language, rather than Arabic and closely identified themselves with the people they ruled. They trekked throughout the countryside visiting Chiefs and villages and attended the religious and social occasions. This was in contrast to their relations with Muslim Arabs in Northern Sudan. The African people of the South resist Islamic Arabic culture, because of their experiences with the Al-Mahdi slave trade, slavery and booty. Collins and Deng conclude

\footnotetext{
${ }^{830}$ Idris, op. cit., p. 28.

${ }^{831}$ Kane, Gregory p (1998, September- October). "Slavery in the Sudan”, Headway, Vol. 10, Issue 8, p. 24.
} 
those practices have severely traumatised the indigenous population of the South and they disliked whatever was relevant to Islam and the Arab. ${ }^{832}$

\subsubsection{Marriage}

Intermarriage is one of the models of assimilation that causes disappearance of physical distinctiveness of individuals. ${ }^{833}$ There are different forms of marriages, but two types of marriages dominate in the social institutions of Sudan. First, exogamy is an institution of marriage from outside of a group member category. ${ }^{834}$ The second one is endogamy the opposite of the former; it limits marriage within the category of an in-group, and hence; it is also called in-marriage and it is practiced by both matrilineal and patrilineal societies. ${ }^{835}$

In social structures, each group of these marriages categorises its social practices as the best. The exogamous group defines the endogamous as easily tempted members towards their relatives and describes such form of marriage as incest, which is a restriction or strongly prohibition of sexual relationship with a kin. On the other hand, the endogamous group claims that exogamous marriage smuggles the wealth out from the institutional circles of relatives from an in-group to an outgroup. $^{836}$

The Head of the Islamists in Sudan, Turabi sees intermarriage between Muslim Arabs of the North and the African Animists and the Christians of the South as a possible model that could accelerate assimilation to Arab and Islamic identity in the country. Turabi claims that such exogamous marriage practice could not succeed, because of the colonial power of Great Britain that separated the South from the North. According to El-Affendi, the leader of the Islamists in Sudan, Hassan Abdullah Turabi argues that without the forced separation, the Southern ethnic groups would have disappeared through intermarriage and the gradual diffusion of Arabic and Islam would over take them. ${ }^{837}$

\footnotetext{
${ }^{832}$ Collins, Robert O and Deng, Francis Mading (eds.) (1984). The British in the Sudan 1898-1956, Stanford: Stanford University, pp. 12-13, 124-5.

${ }^{833}$ Simpson, George and Yinger, Milton J (1985). Racial and Cultural Minorities: An Analysis of Prejudice and Discrimination $\left(5^{\text {th }}\right.$ ed.), New York: Plenum, p. 57.

${ }^{834}$ Keesing, Roger M and Strathern, Andrew J (1998). Cultural Anthropology a Contemporary Perspective (3 ${ }^{\text {rd }}$ ed.), New York: Harcourt Brace \& Company, p. 190.

${ }_{835}$ Bourdieu, Pierre (1977). A Theory and Practice, London: Cambridge University p. 34.

${ }^{836}$ Murdock, George (1949). Social Structure, New York: Macmillan, 86.

${ }^{837}$ El Affendi (1990), op. cit., p. 372.
} 
The theory of intermarriages between the 'pagan' Africans of the South and the Muslim Arabs at the North as a political aim to assimilate the 'pagans' to an Islamic and Arab identity in Sudan might be possible; however, it encounters certain social impediments between Muslim Arabs of the Northern Sudan and the indigenous Christians and Animists of the Southern region. First, some Muslim Arabs defy exogamous marriage in their central and dominant social structures. A boy or a girl at the stage of puberty is oriented towards a kin as his/her cohabitate spouse in the future. This form of social custom is contrary to the African Christians and Animists in the South. These groups observe incest and their boys and girls adhere to the exogamous marriages.

This observation is derived from the answers of some Arab and African students to the question, "Do you think cross marriages can curtail regional diversity in Sudan and if so, what marriage do you prefer and explain why?" One example comes from a Muslim Arab student who states: "I am still single and have already chosen endogamous marriage .... I will marry my relative, on the basis of love and my cultural orientation I received from my family. My culture oriented me to observe endogamous marriage ... and it is good for us to marry a relative, because it has so many more advantages than exogamous". ${ }^{838}$ In contrast, a Dinka student states: "I prefer an exogamous marriage for the reason that endogamous is awful; it is incest. I will marry a non-relative provided that he is a Dinka". ${ }^{839}$ According to Deng, the issue of incest gives the freedom to African descents to marry from outside, but the Arab Muslims and the Arabised ones of Sudan marry among their relative group that could be related in blood as kin. ${ }^{840}$

The few above instances show that intermarriage of Muslim Arabs with the indigenous Africans is flawed. For instance, the Nilotic ethnic groups with their cultural 'conservative' ways do not limit their males to remain in a constant resistance to intermarriages. A Nilotic male could cross the territorial ethnic border and marry from another ethnic group or anywhere in the world. This crossing system of males is not equally encouraged to the extent the females. The Nilotic girls live under the orientation that the cow is a dignified symbol to be married with. It elucidates to the spouses the mysterious intrinsic cultural commitment to one another. It is the ultimate emblem of identity which cannot be taken away from an owner by any other issue, than the extreme one such as a concrete love for a certain woman. From this perspective, the majority of them resist marriage

\footnotetext{
${ }^{838}$ Muhammed Abdel Kalid, a Shaiqqiyyia Arab Muslim at University of Khartoum.

${ }^{839}$ Aluel Majok a Dinka Christian Animist girl at University of Khartoum.

${ }^{840}$ Deng, Francis Mading (1970). Tradition and Modernization: A Challenge for Law among the Dinka, New Haven: Yale University Press, p. 289; See also Deng, Francis Mading (1980) Dinka Cosmology, London: Ithaca, p. 57.
} 
from the outside, especially to Arab Muslims. A Dinka girl who is married outside is conscious of social derogatory attachments to her social identity. The Dinka people will describe her possibly as a common lady, as easily going to the Muslim Arabs and above all, a 'public girl'. Dinka student girls explain this situation as: "I prefer exogamous marriage, and I will marry a non-relative for the reason that endogamous is ... an awesome culture. We are customarily exogamous. Yet, I feel as a Dinka to be married with cows. Without them, then I have no clear image of pride as a truly married Dinka woman". ${ }^{841}$ Another one says: "In our extreme cultural norms, a Dinka woman from a decent family and respected one cannot go to be married with an Arab, even if, he buys thousands of cows for the realisation of that marriage. The issue is not ... cattle, but dignity not to become partly assimilated into an Arab culture. If she does so, then, she is culturally dead. She would be everything representing a bad face to the Dinka". ${ }^{842}$ One girl concludes: "It cannot ... happen to me to be married with an Arab; I seriously respect my culture and adhere to it as my identity and of course, it is important for a spouse to marry you with cows: It expresses the intrinsic beauty of his commitment to love, since he loves his cows than everything except marriage can remove them from him. Yet, I shall marry a Dinka, because he understands this cultural commitment". ${ }^{843}$ Deng questions whether exogamous marriages could be possible between the Dinka and the Arabs to the Chiefs of the Dinka in Upper Nile and Bahr el-Ghazal regions of South Sudan. Chief Makuei Bilkuei from Ruweng of Western Upper Nile region replied: "It will be difficult for the Dinka to give their daughters to the non-Dinka". ${ }^{844}$, but Chol Adija from Abyei took a conservative line and described the Dinka girls who were married to the Arabs as 'prostitutes' and asked 'Have you seen any decent girl, a daughter of a gentleman, marrying an Arab?" 845

The assertions of the Dinka elder with power of decision-making ${ }^{846}$ that it would be 'difficult' for the Dinka to allow their daughters to marry outside the Dinka may carry some racial concepts. ${ }^{847}$ However, 'difficult' could also be explained in the sense that the Dinka identity is based on cattle. It is under this concept of identity which dictates them to pay a dowry in the form of cows and bulls.

\footnotetext{
${ }^{841}$ Nyanut Deng, Christian Animist, University of Juba.

${ }^{842}$ Awien A. University of Juba.

${ }^{843}$ Sarah Ayam, a Shilluk, Christian Animist, University of Upper Nile.

${ }^{844}$ Deng (1978), op. cit., p. 43.

${ }^{845}$ Ibid.

${ }^{846}$ Fallers, LIoyd A (1973). Inequality Social Stratification Reconsidered, Chicago: The University of Chicago Press, p. 38. In Africa Chiefs are the decision-makers in political and social institutions.

${ }^{847}$ Omi, Michael and Winant, Howard (eds.) (1994). Racial Formation in the United States from 1960s to 1990s $\left(2^{\text {nd }}\right.$ ed.), London: Routledge, p. 45. Races are built in institutions.
} 
It is not easy for an alien to secure the number of required cows as payment in order to marry a Dinka girl. To marry a Dinka girl one must be prepared to answer many demands for cattle from the extended relatives of a girl. Their demand is mostly an expression of this cultural pride over their collective right on a daughter assumed as 'our daughter'. An expected marriage of a Dinka gentleman must be above one hundred cows and beyond. According to Deng, marriage from the Dinka ethnic group by other ethnic identities is impeded by the expensiveness of the payment of a dowry in the form of cows as a unique expression of indebted right to a girl that is regarded as "our girl". Dinka concludes that among the Dinka, a single woman costs not less than one hundred and fifty cows. ${ }^{848}$

Second, the term 'difficult' may also mean that the Dinka as members of the Nilotic ethnic groups are difficult to be assimilated to any an outside culture through marriage. Experience proves that they are not adaptable to change of their culture. A Dinka Christian- Animist girl states: "For me to marry a non-Dinka is a total displacement of my whole ... identity. My language is my identity, when my mother speaks in Dinka proverbs I understand which one is for social justice and which one is for prayer and which one is for our economy. It does not cross my mind to marry a nonDinka that would lead me off the track of my customs; leave alone an Arab Muslim". 849

We must extract two issues from the resistance of this Dinka female student to establish marriage relationship with a non-Dinka for analysis. First, her resistance is based on the intertwined validity of the Dinka language to the maintenance of her traditional customs. Her language makes her closer to the religious world; it brings her closer to understand and interpret what is 'just' and wrong in reference to the traditions of the Dinka institutions. The same language teaches her perseverance through some social difficulties, until success is achieved. Second, her statement gives an impression of the conservative line that she will not marry a non-Dinka; if she did so it would carry her away from her linguistic community, where she understands its proverbs. Two scholars who have studied the Dinka have noted the presence of such expressions as those of the Dinka girl in the Dinka traditions. First, according to Nikkel, the Dinka use their rich language in different forms of proverbs to express different issues to maintain traditional perseverance to social hardship and refrain from stealing and running away from a defined enemy. One instance is that the Dinka say

\footnotetext{
${ }^{848}$ Deng (1978), op. cit., p. 202.

${ }^{849}$ N K K, University of Juba.
} 
Nhialic agur abik to mean "God is grinding fine flour; what remains is the sifting". ${ }^{850}$ This traditional proverb is applied to invite the group, during war, famine, or any form of unbearable suffering. When it appears to the Dinka people that the land of Nhialic (God) who brings blessing and hardship is brutally crushing his people, even then, the wisdom of God is at work. It is grinding the excellent flour for the satisfaction of the people. ${ }^{851}$ Second, Deng says that the Nilotics, especially two ethnic groups, the Dinka and Nuer are very conservative and resistant to change. Many anthropological and sociological scholars observe this phenomenon and describe them as proud, and belief in their value system mainly derives from their religions and customs. Deng concludes that this social system has remained as a defensive weapon against linguistic cultural interference from the Muslim Arabs. ${ }^{852}$

Third, theoretically, violence creates negative sentiment to a social community. Such sentiment places social barriers between communities. ${ }^{853}$ The existing long violence between 'Christian Animists' in the South and Muslim Arabs in the North disqualifies the claim that intermarriage could successfully occur between these groups. Domestic 'slavery', racism and ethnic violence, based on the slogan of religion between Arab Muslim identities and the African Christian and Animists has negative impacts on social relations between the young men and women. ${ }^{854}$ Observations of this researcher of the relationships of students at different campuses reveal the presence of social borders which cannot be easily crossed at the moment, unless the state introduces a change of attitudes. In public, every Christian girl walks with a Christian Animist and the same phenomenon is seen among the Muslim Arab girls. They mostly appear with Muslim Arabs on different campuses and not with Christians or Animists of the South. It seems that a racial hatred has been created by the sentiment of conflict; a Nuer student at University of Juba states: "I can't marry a Muslim Arab in Sudan; why would you marry the daughter of a foe?"855

This student's assertion does not conform to the opinion of one of the leading political Muslim figure in Sudan. Recently, the policy of assimilation based on marriage has shifted from the political propaganda of assimilating the Christians and the Animists through the marriage to their daughters to an exogamous free choice of marriage that is not limited only to the ethnic groups of

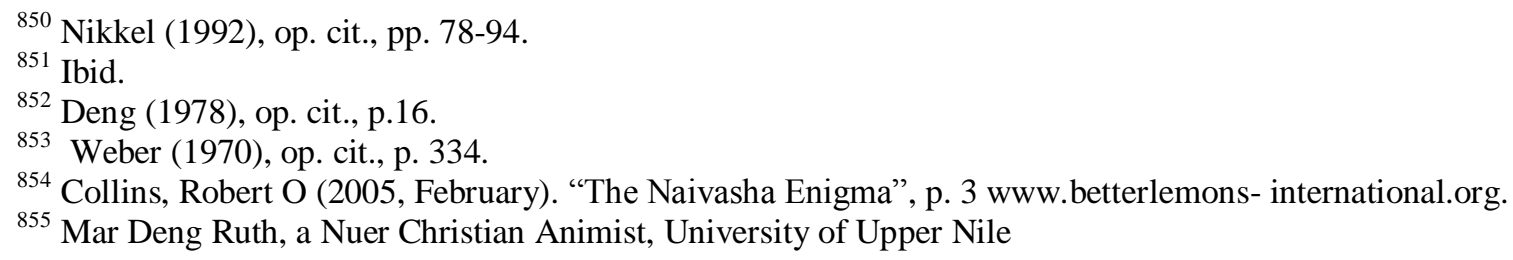


the South for the purpose of assimilation to Islamic and Arab cultural identity. Hassan Abdullah Turabi issues at different political forums fatwaat (Islamic legal edicts) which invite Muslims to disregard the limitation in marriage. For him, it is legal for a Christian and a Jew to get into a social relation leading to a marriage with a Muslim female. ${ }^{856}$ In contemporary Sudan, Muslims and Christians have already engaged in intermarriages in an official way. Residents of the city of Gadaref followed an open marriage ceremony of a Muslim girl to a Christian man. Witnesses to occasion were extremely amazed. The open ceremony was conducted following some traditional Muslim customs of the Northern Sudan. ${ }^{857}$

Observers interpret this marriage as the beginning of the implementation of exogamous legal marriages of a Christian to a Muslim woman conforming to the religious edicts of Turabi. This Muslim leader invites Christians to avoid shying away from establishing intimate social relationships with the Muslim women for marriage. And in order to attract the young Christians to the intermarriage, the organisers made the wedding to be celebrated for many hours in two locations. The first was celebrated at the main Church of the city. After the end of the matrimony service from this church, a second service was held at the bride's home. ${ }^{858}$ The participants and the others passing by have witnessed the social marriage of two opposing religions in Sudan and reported that the girl expressed strong happiness towards having married a Christian. She explained to have a full conviction with the whole idea and defends her decision to marry a non-Muslim as a response to Turabi's verdict to marry a Christian. The marriage, however, divided the family of the bride, some supported the right of a woman to be married to a Christian, but other relatives of the girl were reported to be furious about the choice of their girl to marry a non-Muslim. ${ }^{859}$ In the Islamic religious view, it is reported in Khartoum daily Arabic Newspaper that a certain Sheikh forbids such marriage. Abdul Fatah Iddriss, a professor of comparative Fiqh (Islamic jurisprudence) in the faculty of Sharia at Al-Azhar University dismisses the marriage. He asserts that the marriage of a Muslim woman to a non-Muslim is haram (not allowed) in accordance with Sharia text. Iddriss

\footnotetext{
${ }^{856}$ Shreq al-Awsat (2007, July 2). "Turabi Ysamah al-Zwaj bean Bit Muslima wa Nassari, Turabi Continues to Permit Marriage between a Christian and a Muslim Woman", Arabic Newspaper, Shreq al-Awsat, Vol. 1078, p. 1.

${ }^{857}$ Shreq al-Awsat (2006, February). "Fita Sudania Muslima tatazoj min Massiahe wa testanid le fatwa al Turabi. Sudanese Muslim Girl Marries from a Christian in Accordance to Turabi Edict”, Arabic Newspaper Shreq al-Awsat, No. 10037, p. 2.

${ }^{858}$ Ray Al-Aam (2006, February). "Al-Zuaj in Gadaref been al-Bit al-Mslima and Nasari”, "Marriage in Gadaref between the Muslim Girl and Christian”, Arabic News-paper, Ray-Al-Aam, p. 3 www.Ray aam.net.

${ }^{859}$ Shreq al-Awsat (2006, February). "Fita Sudania Muslima tatazoj min Massiahe wa testanid le fatwa al Turabi". Sudanese Muslim Girl Marries from a Christian in Accordance to Turabi Edict, Arabic Newspaper Shreq al-Awsat, No. 10037, p. 2.
} 
gives his rejection to the intermarriage with a proof. He argues that God states in the Holy Quran: "and do not sleep with infidels, until they believe". 860

The occasion of the intermarriage between a Christian man and a Muslim woman within the territorial jurisdiction of the Northern Sudan, where the Sharia is applied is a turning point in religious relationships and may lead to the highest status of religious tolerance. This phenomenon challenges the religious borders, under the laws which the student describes as follows: "Legislature body makes dubious racial laws that remove freedom of individual girls and boys to create intimate relationships that may lead to marriage and to making a family. It is really a pity and a point of our dislike of the ... regime of President Al-Bashir that places itself above us and decides for us the directions to take on issues falling within the boundaries of individuals". ${ }^{861}$ A girl from Misseiryyia Arab of Southern Kordofan at University of Khartoum argues: "I am a single girl and will marry a non-Muslim, if he wants to marry me, especially my neighbours, the Dinka from Abyei. It is a choice for the legislative powers of Sudan to choose between setting religion aside and allowing the choice of marriage to individuals' satisfaction to each other. Otherwise, we ... will resist these laws in different ways in our political ideologies in Sudan". 862

The organised phenomena of assimilation models, which intend to assimilate the minority Christians and Animists in the south to an orthodox Islamic-Arab culture in Sudan leads to violence. According to Mushanga, in Sudan the dispossessed group adopts violence for the amelioration of their cultural, political and economic conditions. ${ }^{863}$

\footnotetext{
${ }^{860}$ Ray Al-Aam (2006, February). "Al-Zuaj in Gadaref been al-Bit al-Mslima and Nasari. Marriage in Gadaref between the Muslim Girl and the Christian Man”, Arabic News-paper, Ray-Al-Aam, www.Ray aam.net.

${ }^{861} \mathrm{~S}$ Adel A Muslim Arab, Shaiqqiyyia, University of Khartoum

${ }^{862}$ Makkaha Eisa, University of Khartoum.

${ }^{863}$ Mushanga, Timbamanyamwene (ed.) (2004). Criminology in Africa ( $1^{\text {st }}$ ed.), Kampala: Fountain Publishers, p. i.
} 


\section{VIOLENCE OF IDEOLOGIES}

Risto Marjomaa asks why has war been pursued and why does it crucially continue to persist at present to haunt our societies around the world $?^{864}$ Generally, what engenders detrimental violence to break out among people in political and social institutions is not uniform. Every political and cultural institution has its different ideological discourses of violence. For Clausewitz "war is a continuation of politics by other means". ${ }^{865}$ And others claim that "violence is a midwife of history". ${ }^{866}$ It is an instrument which oppressed and exploited classes adopt in confronting an oppressive and exploiting class of power. Thus, the oppressed and exploited classes apply it to rectify such a situation through change, but a unique "change that comes through the barrel of a gun". 867

The students interviewed for this study think that there are ideological complexities which cause the long and repetitive civil wars in Sudan. ${ }^{868}$ Such opinions can be found in answers to the question "Do you think the exclusion of the South has a link with the past civil wars between the South and the North, and if you think so, what about the current violence within the North as in Darfur, how do you evaluate it?" Some students argue that: "The civil war of the indigenous African Muslims, Christians, and Animists from Darfur, Nuba Mountains, Ingessana Hills and Beja against the ruling elite Muslim Arabs in power is caused by political and economic marginalisation, under the autocratic military system that marginalises us although we represent majority". ${ }^{869}$ Another one states: "The elite Muslim Arabs in power practice political marginalisation in distribution of wealth and power. So, we have a war between the marginalised African majority groups as one body against the marginalising Arab Muslim minority in power". ${ }^{870}$ On the other hand, other Muslim Arab students argue that: "Sharing of power and wealth in Sudan equally with other regions which

\footnotetext{
${ }^{864}$ Marjomaa, Risto (1998). War on the Savannah the Military Collapse of the Sokoto Caliphate under the Invasion of the British Empire 1897-1903, Helsinki: the Finnish Academy of Science and Letters, p. 9.

${ }^{865}$ Clausewitz, Karl von (1968). On War, Harmonthsworth: Penguin, p. 32.

${ }^{866}$ Robertson, Ian (1987), op. cit., p. 519. For Karl Max, war is "a midwife" of human history that addresses the relationship between the oppressed and the oppressor.

${ }^{867} \mathrm{Ibid}$, the Communist leader, Mao Tse-tung a change of a system requires a gun against the enemy, p. 519.

${ }^{868}$ Sidhamed, Abdel Salam (1997). Politics and Islam in Contemporary Sudan, Surrey: Curzon Press, p. 15. Burr, J Millard and Collins, Robert O (1995). Requiem for the Sudan War Drought and Disaster Relief on the Nile, SanFrancisco: Westview Press, p. 127. Woodward, Peter (1990). Sudan, 1898-1989 the Unstable State, London: Lester Crook Academic Publishing, p. 53.

${ }^{869}$ Najwa Hashim Mugtar, a Muslim Beja, University of Khartoum.

${ }^{870}$ Seisi Debbi Adam, a Muslim Fur, University of Juba.
} 
claim marginalisation was not possible, since the foundation of Sudan as a state. Institution building commenced in the northern Sudan and the remaining regions embraced enormous illiteracy. Ergo, 'illiterates' could not hold power in national institutions". ${ }^{871}$ One of them concludes that: 'The socalled 'marginalised regions have no wealth which they produce from their lands and the Arabs refuse them the development of their areas". 872

The issue of locally produced wealth in Sudan was defined in the Sudan Constitution of 1973. The constitution said that the revenues of natural resources from the South would accrue to the Southern Government". ${ }^{873}$ In 1979, the American company Chevron discovered oil in Western Upper Nile Province, specifically the area of Bentiu in South Sudan. President Nimeiri with Attorney General, Hassan Abdulla Al-Turabi stepped in to establish new re-demarcation of borders between the South and the North. The oil areas annexed to the North, however, had to be withdrawn, after a series of demonstrations in resistance to it and the total refusal of the Southern Regional General Assembly as well as Abel Alier, President of the South to acknowledge the new borders. ${ }^{874}$

These conflicting political discourses between those who claim that their regions have undergone a series of marginalisations in terms of economic development and power-sharing and those who reject the claim have shifted to the category of an ideological defined discourse of 'the marginalised' identities in opposition to the 'marginalising' Muslim Arabs in Sudan. It has become a national identity for the majority of students in the South, Darfur, Nuba Mountains, Ingessana Hills and Beja. These groups identify themselves as "the marginalised majority". 875

From this perspective, there is an ideological identity called the 'marginalised' which surfaced from the economic and power sharing circumstances within Sudan. Yet, political disputes are not only based on economic and power dimensions in Sudan. Even though the students from the South

\footnotetext{
${ }^{871}$ Mohammad Hasan Abas, Muslim Arabs, a Ja’alei Muslim, Omdurman Ahlia University.

${ }^{872}$ Mohammad Bin Abdullah, a Shoukuri Muslim, University of Khartoum: "The so called marginalised regions do not contribute something from their regions to the national wealth of the state. How would they expect the wealth of the north be taken to them?: "We have not seen something being produced from Darfur, Nuba Mountains and the Muslim Arabs refuse it for their development".

${ }^{873}$ Constitution of the Republic of Sudan Entered into Force August 1973.

${ }^{874}$ Ibid.

${ }^{875}$ Hend Abdella Adam, a Muslim Fur, University of Khartoum: "We the marginalised ... from the South, the Beja, Darfur, Ingessana and Nuba Mountains have defined the better constitution in Sudan. The marginalised power from Darfur, South Sudan, Beja and Nuba Mountains is emerging. We will win the democratic elections one time and put a good system in Sudan. "The Beja are Muslims, yet we identify ourselves now with the marginalised from the South, west and the far north".
} 
claim a unified political identity known as 'marginalised' with the other regions. ${ }^{876}$ The majority of them also argue that religion and ethnicity are the cardinal conflicting criteria responsible for the instability of political Sudan. ${ }^{877}$

The Addis Agreement created in the South a 'Regional Self Government' (RSG) which was incorporated into the Permanent Constitution of Sudan. That constitution acknowledged the dualistic presence of Arab and African identities in Sudan, respected Islam, Christianity and Animism and prohibited discrimination on the basis of religion, race, gender and language. ${ }^{878}$ Christian and Animist students of the South claim that these provisions have never been observed. Muslim Arabs in power have introduced many political initiatives in violation of this 'Permanent Constitution'. For example, President Nimeiri violated the constitution by dividing the South in 1983 into small regions, which led to the resumption of war in $1983 .{ }^{879}$ On the other hand, some Muslim Arab students argue that the constitution was a 'pagan' one, since; it disregarded Islam in its provisions ${ }^{880}$., under the pretence that Islamic law discriminated against the non-Muslims. There is no discrimination in Islam', since the Sharia preserves the prevailing ethnic and religious diversity in Sudan, by protecting individual non-Muslim minority rights. ${ }^{881}$ According to another student, constitutions which are void of Islam mainly promote paganism. ${ }^{882}$ One of them concludes that the Christians and pagans in the South have a conspiracy to eradicate Islam from political and social structures of Sudan. ${ }^{883}$

It is very common among many Muslim Arab students to label the people of the South as the 'pagans' and the people of the other regions as religious Muslims. In this sense, Muslim Arab

\footnotetext{
${ }^{876}$ Dut Ngor Atak, a Dinka Christian Animist, University of Juba: "It is not only the people of the South and Nuba Mountains who are marginalised. Darfur and Beja regions are included in this class".

${ }^{877}$ Kiir Mangong, a Dinka Christian Animist, University of Juba: "Muslim Arabs are oppressors against an African identity. They want to make us become Muslim-Arabs through the constitution. I like all the constitutions, except the constitution of Islamisation and Arabisation".

${ }^{878}$ Lesch, op. cit., p. 47.

${ }^{879}$ Elia Padiet, a Collo at University of Juba "many constitutions in Sudan have been violated by the Muslims in power. Nimeiri violated the constitution of 1973 and called it was not a Quran or a Bible". Peter Mel, a Dinka at University of Bahr el-Ghazal "Nimeiri divided the South into three regions in 1983 and that was a violation of the Permanent Constitution".

${ }^{880}$ Al-Jaeli Muhammad, a Shaiqqiyyia Muslim, Omdurman Ahlia University: "The Constitution of 1973 was the worst constitution. It made us all appeared as pagans". Linda Hussein, a Kababish, Omdurman Ahlia University: "Un-Islamic constitution of Nimeiri of 1973 was made under the claim to avoid discrimination. Sharia protects the rights of nonMuslims and promotes ethnic diversity".

${ }^{881}$ Nemaat Mustafa, Ja'aleen at University of Khartoum.

${ }^{882}$ Zeinab Badr el-Din Ali, a Shaiqqiyyia, University of Juba: "Any constitution which does not consider Sharia is intended for the promotion of paganism".

${ }^{883}$ Mudiha Abdulla Mohammad, a Misseiriyyia, University of Khartoum: "Christians and pagans in the South unite with the enemies of Islam to remove Sharia from the constitution. Our social life is based on this law".
} 
students assume that the problem of addressing national identity constitutionally is not a problematic issue to the other regions, where Islam is a religion of the majority, except for the pagan South. This view is not accepted by some students from the South. For instance, one of them argues: "We the Christian Animists in the South and traditional African Muslims in Nuba Mountains, Ingessana Hills and Darfur know those Arab Muslims in power do not respect any constitution. We the marginalised from these regions want to promote our African way of practicing Islam and Christianity in the national constitution". ${ }^{884}$ Another one states: "We want a secular constitution. We cannot accept ... to be dragged into the extreme religious practices of fundamentalism. We have no fundamentalism in our traditional practice of religion. Muslim Arabs want to assimilate us and that was the reason our leader Dr. John Garang rejected the Addis-Ababa Agreement. The agreement was made to deceive the Christians and the Animists of the South to put down their guns and to annihilate our African identity with Islamic fundamentalism", 885

John Garang De Mabior who was a founder of the guerrilla political organisation, SPLM with its military branch SPLA in 1983 was interview in the Sudanese magazine, Heritage. Garang himself explains his rejection of the terms of the Addis Ababa Agreement, because its basic terms were first to absorb the Anya Nya (military wing of the rebels) into the National Army. Second, it was to integrate it after absorption and third to destroy it. So, the main aim was to achieve a cheap victory over the Anya Nya forces which fought the war. In brief, the concrete basis for the agreement was to disarm the Anya Nya combatants that had proved formidable in the battlefield through peace. Garang concludes that all the other coding; vis-à-vis the Regional Self-Government Act, the ministerial posts and all things connected with the local autonomy were only peripheral, the main objective was to pull out the arms from the Anya Nya and finally neutralise it and destroy it. ${ }^{886}$

Political relationships of President Nimeiri with the Autonomous Government of the Christian and Animist South justify Garang's claim. Later he published the legality of the agreement and dismissed the elected members of the regional assembly in Juba, the capital city of the South in 1983. The terms of the agreement articulated that the South was to maintain its special status of an autonomous system of a government, six thousand of the Anya Nya soldiers would be absorbed to the national army and stationed in the South. In 1983, Nimeiri decreed the re-division of the South

\footnotetext{
${ }^{884}$ Justin Bol, University of Juba.

${ }^{885}$ Atem Chol Athuei, a Dinka, University of Juba.

${ }^{886}$ Heritage, op. cit., pp. 4-5.
} 
into three regions. This division came after he had applied the policy of "rule and divide" 887 among the political forces of the South. The majority of the people from Equatoria province supported the re-division on the basis that the Dinka dominated the region. Fearing the reaction of the majority of the Christian-Animists to the re-division, Nimeiri ordered the transfer of the former Anya Nya soldiers from the Southern zones to the North. On 15 May 1983, 'Colonel 'Dr' John Garang, a Christian from the Dinka rebelled with some former Anya Nya armed forces in Bor, South Sudan. Garang formed the SPLA and the SPLM on the ideological vision of building "New Sudan". 888

\subsection{New Sudan}

Janis observes that in some cases of group decision-making, individual loyalty to a group prevents members from raising controversial and uncomfortable questions. The members become concerned about the maintenance of group harmony at critical times, especially, when a difficult issue related to their values and culture emerges. The group ceases from criticising its leader(s) and looks primarily to the issue(s) affecting them. This collective decision is called 'groupthink', a descriptive approach of a group, either to ignore a situation or propose alternative resolutions to the threatening problem. ${ }^{889}$

Observations and answers by the Christian and the Animist students offer a clear example of such 'groupthink'. The students support their political leaders on the issues of their territorial identity, the South as well as in defence of their Animistic religions mixed with Christianity. They claim that one time, the Nilotic ethnic groups had to drop their differences, after they realised that Nimeiri wanted to disperse the Anya Nya soldiers, by transferring them to the North as a plan of implementing his decree of re-dividing the South into small regions. They unanimously felt that they were vulnerable to the system that strived to destroy their territorial unity. This public solidarity motivated the majority of them to support their political leaders that interpreted the fragmentation of the South from one entity into three regions as a serious marginalisation in decision-making on the issue that concerned their territorial destiny. Political activists dropped their differences and coordinated with the former Anya Nya soldiers secretly to confront the Nimeiri system with violence. The students explain their 'groupthink' as a Nuer student states: 'Our brothers, Jiang (Dinka) fight with us sometimes on the issues of individual interest ..., but we could

\footnotetext{
${ }^{887}$ Kebbede, op.cit, pp. 19-20.

888 Ibid.

${ }^{889}$ Janis, Irving (1972). Victims of Groupthink, Boston: Houghton Mifflin, p. 147.
} 
simply merge together when there is a threat to our public existence and our religion. When Nimeiri tried to destroy our army, the Anya Nya, in order to re-divide the South into three regions, we the Nilotics were very quick to know the mystery behind it and opposed the re-division". ${ }^{890}$ Second, a Dinka states: "Sometimes, we the Nilotics, Jiang, Nuer, Collo, Anyuak and Luwo come into political confrontation leading to human casualties, but the question of our territory and religious practices of our traditions ... bring us together against the Muslim Arabs". 891

A Shilluk student claims: "During the Regional Autonomous Government in Juba, the Nilotics had some disagreements among themselves, but we dropped them, when Nimeiri wanted to eradicate our culture and we took guns to fight him as members of the SPLM and SPLA, since 1983". ${ }^{892}$ Another one claims: "When Joseph Lagu from the Amadi ethnic group of the Eastern Equatoria ... became the Vice President of Sudan and planned with Nimeiri to re-divide the South, the majority of the Nilotic ethnic groups represented in the Regional Assembly in Juba dropped their differences and decisively voted against the proposed re-division of the South" ${ }^{893}$ Another notes: "After the re-division of the South, disparate armed resistance and popular uprising from different areas of the Nilotics of Abyei, Bentiu, Aweil, Rumbek and Nasir started. On 15 May 1983, the former Anya Nya soldiers mostly composed of the Nilotics at the small town, Bor in the South rebelled against the system of Nimeiri ${ }^{894}$. One of them concludes: "Colonel John Garang de Mabior was clandestinely the head of the rebellion and his junior assistant, Major Kerbino Kuanyin Bol implemented the rebellion, before Garang could arrive from Khartoum. The Christian-Animist soldiers stationed in their thousands at the zones of Pachalla, Pibor and other garrisons in the South responded and followed Garang to the bush forming the SPLA and the SPLM. ${ }^{895}$

In the bush, the SPLM commenced to organise itself and produced a political document, manifesto, in which it defined the aims of the rebellion. The manifesto calls for the establishment of 'New Sudan', which is a national political framework that reshapes Sudan towards equality, democracy, freedom and progress to all essential ingredients of Sudan's diverse society for its stability, under a genuine democratic pluralism. The SPLM articulated that the identification of

\footnotetext{
${ }^{890}$ Chol Deng, University of Upper Nile.

${ }^{891}$ Wek Madut Deng, University of Bahr el-Ghazal.

${ }^{892}$ Adiang Kur, a Shilluk, University of Upper Nile.

${ }^{893}$ Joseph Akol, Omdurman Ahlia University.

${ }^{894}$ Akec Duer, University of Bahr el-Ghazal.

${ }^{895}$ Kebbede, op. cit., p. 16.
} 
these defined aims was based on a transformative process taking into consideration the positive elements of 'Old Sudan' and inserting them into the challenges that will face Sudan as a state. ${ }^{896}$

\subsubsection{The Birth of the SPLM and SPLA}

Social theory maintains that organisations need leaders with virtue of some unique qualities of consistency and capability to influence the behaviours of others. There are two types of leadership: first, instrumental leadership and second expressive leadership. The former refers to a leader organising a group in pursuit of certain goals. Such a leader poses courses of action and influences the members to follow him or her. The latter type is referred to as a creative leader that strives to maintain harmony and solidarity among the members. She or he keeps morale high and tries to minimise conflicts among the group. ${ }^{897}$

Some of the Christian Animist students reiterate that, before Garang could build the SPLM and the SPLA, there was already in existence a Southern Sudan revolutionary organisation composed of some former Anya Nya members calling itself Anya Nya II. ${ }^{898}$ This organisation was disorganised and lacked charismatic leadership quality. ${ }^{899}$ Garang emerged as both an instrumental and expressive leader and objected those to who wanted the movement to be called 'Anya Nya II' insisting on the nationalist slogan based on the liberation of Sudan rather than the South alone. This was the birth of his revolutionary organisations, the SPLA and the SPLM. ${ }^{900}$ Garang's adoption of the slogan of liberating Sudan caused a dis-comfort among some Northern Sudanese Muslim Arab students. For instance, one student states the question as: "liberation of Sudan from whom?"901 The Nuba Muslim student at University of Khartoum provides the answer as: "The Northern Sudanese

\footnotetext{
${ }^{896}$ Manifesto of the Sudan People's Liberation Movement, 2008, April, p. 24.

${ }^{897}$ Slater, Philip (1955). Role Differentiation in Small Groups, New York: Knofp, p.76.

${ }^{898}$ John Mou Thuc, a Dinka, University of Bahr el-Ghazal: "When Dr John and others rebelled in Bor, there were already Anya Nya soldiers in Ethiopia”.

${ }^{899}$ Mary Awal, a Dinka, University of Juba: "When those of Dr John Garang, Kerbino Kuanynin, our current president, Salva Kiir Mayardit defected from the army there was a disorganised body composed of the Anya Nya at the border of Ethiopia which Garang organised and turned it into the SPLM and SPLA".

${ }^{900}$ Khalid Mustafa, a Muslim Nuba, University of Khartoum: "John Garang was an instrument of the new body, the SPLA and SPLM. He got some difficulties to convince the former rebels, the Anya Nya to accept the liberation of other marginalised regions in Sudan from the domination of Muslim Arabs in power". Ahmed Saad, a Fur, University of Khartoum: "Some Fur people were convinced of the expressive political statements of John Garang. He was consistent with the programme of liberating the marginal regions such as Darfur, Nuba Mountains and Beja from the Arab Muslims domination, thus Yahiya Bolad joined the Movement". Dor Chol, a Dinka, University of Juba: "Garang persuaded the Anya Nya to drop their concept of liberating the South under the name of Anya Nya Two".

${ }^{901}$ Ahmed Hashim, a Shaiqqiyyia Arab Muslim, University of Omdurman Ahlia: "What is strange in the Garang's organisation is the name itself, Sudan People's Liberation Movement and Army. I am not sure, a Liberation of Sudan from whom?
} 
Muslim Arabs dominated power and defined the national identity of the country as Islamic Arab. This is the definition which John Garang wants us ... to be liberated from it, but Muslim Arabs ask the question; "liberation from whom?" 902

A philosophical method of persuasion to acquire reputed wisdom divides the discussion into two preoccupations. The first is questions and answers and the second is definitions. ${ }^{903}$ Garang meets those Muslim Arabs of Northern Sudan that dispute his slogan for liberation with a reverse question "Do not ask me of liberation from whom, but liberation from what." 904 He argued that the minority Muslim Arabs use the Islamic religion as a tool of homogenising the heterogeneous Africans of other regions. This political initiative seeks to bring the combined five regions of the Northern Sudan into one body built on a religion and race. Such formation defined racially and religiously as 'the Northern Sudan of Muslim Arabs'. According to Garang, this method marginalises the majority Africans, under the minority Muslim Arabs. He concludes that the percentage of Arabs in Sudan in the first census after was a mere $31 \%$, while Africans formed $61 \%$ and $8 \%$ were mostly West Africans stranded in Sudan, during their way or returning from Islamic pilgrimage in Mecca. ${ }^{905}$

Two months after the formation of the SPLM and the SPLA, Garang issued a manifesto for his organisation in July 1983 expounding his objectives. In this manifesto, the territorial national identity of Sudan is defined as multi-religious and multi-cultured. It presents the adoption of as an alternative resolution to the maintenance of this diversity within a united 'New Sudan'. The manifesto asserts that an ethnic pluralist constitution based on the territorial diversity of the country would protect the minorities and provide equal opportunities in sharing power and wealth as well as equal legal rights. ${ }^{906}$ In the view of Graham, the marginalisation of a state to minorities causes communal riots with the possibility that fresh disturbances could constantly break out. All these factors inevitably could pave the way for popular minorities to secede from a sovereign state. Graham concludes that the commitment to the conceptual idea of building a secular diverse nationstate provides a political space for minorities in a territory of religious diversity. ${ }^{907}$

\footnotetext{
902 Thuria Ahmed, University of Juba.

${ }^{903}$ Scott-Kakures, Dion et al. (1993). History of Philosophy Why, New York: Harper Perennial, p. 18. Socrates, an Ancient Greek philosopher applies two preoccupations in his discussions, first, preoccupation with questions and answers and second with definitions.

${ }^{904}$ Garang, John de Mabior "Problem of Sudan" in Mansur Khalid (ed.) (1996) John Garang Speaks, New York: Kegan Paul International, p.8.

905 Ibid.

${ }^{906}$ Manifesto of the SPLM/A July 1983.

${ }^{907}$ Graham, Bruce (1990). Hindu Nationalism and Indian Politics, Cambridge: Cambridge University Press, pp. 8-9.
} 
Some students from the South argue that they rally behind the revolution, SPLM and SPLA, under the ideology of 'New Sudan', because Garang's approach to the war assured them what they were fighting to obtain. The primary target was the liberation of the South. ${ }^{908}$ However, Garang pursued the war in tactical strategies in what he calls "transfer of war to the enemy, but the ultimate objective was always the liberation of Southern Sudan". ${ }^{909}$ Garang never deviated from his essential aim of fighting for the liberation of the South against the successive governments in Khartoum. The aim in Garang's political vocabulary can only be understood through his military addresses to his soldiers. His vision of liberating the whole Sudan was to engage 'the enemy' in a wider sense, but he knew in operation what he had wanted to liberate first. He demanded the bigger cake in order to receive an alternative as a hidden target. First, addressing his recruits at their graduation camp in Bongo in Ethiopia on 7 March 1985, Garang told the following apocryphal stories. First, he told the story of a well-known gluttonous man in Bahr el-Ghazal, South Sudan called Col Moung. One day, he came out from his homeland of Western Gogrial County, and found a large number of hunters skinning an elephant. He abruptly paused and told the hunters: 'Please, listen, after you have finished the skinning of the prey, I want all of its meat with offal; I have a very serious hunger'. The hunters knew Col is a very greedy well known man who meant what he said and unanimously reacted to him: 'Coldit (Big Col) say something reasonable. We have been hunting this animal, since the morning and now you want all of it? You better ask for a thigh'. 'If I were to ask for a thigh, you would not have given it to me. Therefore, since you have now granted me a thigh, I am contented with it', Coldit replied. Similarly, Garang concluded that South Sudan is like that beast. Ask for the whole Sudan and at the end you would receive a thigh (Southern South). ${ }^{910}$

Second at the same place, Bongo on 14 April 1985, Garang gave a speech to the other graduates that said 'Among you, there are those who question the principle of fighting for the liberation of the whole Sudan. This is because you think that we should liberate South Sudan without the political North. For me when 'I was in school, I was not good at geography, therefore, I do not know precisely the geographical borders between the North and the South those who know the borders

\footnotetext{
${ }^{908}$ Dhal Akot Rec, a Christian Animist, University of Juba: "We rallied behind the revolution in the name of 'New Sudan', because Garang had assured us what we were fighting for: Garang taught us the philosophy of 'New Sudan as a way of fighting our enemy and knew how to get the South".

909 Nhial Duany, a Nuer Christian Animist, Upper Nile states "Garang was very intelligent. He uses political slogan of 'New Sudan' in order to transfer the war to the enemy. Without that, the Muslim Arabs would have used our African brothers in Nuba Mountains, Ingessana and Darfur to fight us. But each has known his rights from these regions now and we will get away with our South".

${ }^{910}$ Garang, John de Mabior Narratives on 7 March 1985.
} 
should fight and when they have reached the complete liberation of the bound border that they think of as the South, then stop there. The South by then is believed to have been liberated. 'Me, who does not know the borders between the South and the North, I will continue to fight and if I look behind and see nobody was following me, then I would definitely come back and join the liberated and independent South Sudan". 911

In the view of Johnson, there were two compelling reasons which made Garang name his organisation as a liberation movement for the whole Sudan. First, he wanted to recruit the indigenous African marginalised majority from the west of Sudan, the Nuba, the Darfurians in Darfur, Ingessana Hills at Southern Blue Nile and the Beja of the eastern Sudan to equally fight the centre. These regions, in his view are part of the 'Closed District' laws of 1922 and 1925. The British colonialist system regarded these regions as African areas and Garang had wanted to revive that in the minds of these people. He constructed his ideological term that combined these groups as the 'indigenous marginalised majority'. Second, Garang was faced by the political circumstances that the regime of Ethiopia had no interest to provide logistical support to a separatist organisation, while itself fighting the Eritrean separatists. The primary objective of Ethiopia by then was to topple the government of Nimeiri that supported the Eritrea separatists. ${ }^{912}$

\subsubsection{Response of the Nuba}

Nuba Muslim and Christian students say that the Nuba people were quick to respond to the call of Garang. They began to identify themselves as the 'marginalised'. The question; how did other regions become Northern Sudan to the exclusion of the South? A Nuba student at University of Khartoum answers it as: "The South became a separate region, under the Muslim Arab ideology of adopting Islam as a model of religious uniformity. And the Nuba had to accept it, since Islam is a very important religion in their lives. Later, it turned out to be a method of marginalising the peripheries, including the Nuba". ${ }^{913}$ Another Nuba student claims: "Marginalisation of the Nuba in economic and power distribution makes it easy for the Arabs to assimilate us, because, 'a marginal person relies ... on a wealthy person". ${ }^{914}$ According to Doornbos et al., power in Sudan leaves some of its citizens without equal development opportunities in their regional sovereignties. It is a

\footnotetext{
${ }^{911}$ Garang, John Mabior Narratives on 14 April 1985 April.

912 Johnson (2003), op. cit., p. 62.

${ }_{913}$ Ahmed Adel Tom, a Muslim, Omdurman Ahlia University.

${ }^{914}$ Abdel Munem Kuku, a Muslim, University of Juba.
} 
phenomenon that transforms their identities as independent actors within their regions, but mere sub-ordinate people without decisions over the state's public issues within their respective regions in the country and such practice attracts the marginal areas to rebel against the centre. ${ }^{915}$

In 1986, the SPLM and SPLA attracted some Nuba to its ideological guerrilla activities and many of them marched to the training camps in western Ethiopia. In the following year, during the rainy season, the first battalion, Volcano of the SPLA guerrilla entered the Nuba Mountains, under Commander Abdel Aziz Adam al Hilu. This commander came intentionally to organise a largescale recruitment among the Nuba and reiterate the ideological discourses of the SPLM and SPLA in the region. ${ }^{916}$ A large Number of the Nuba young men volunteered to join the guerrilla movement as one student explains: "After our understanding of the political ideology of the 'marginalised ones', our comrades moved and registered to join the training as soldiers of the SPLA. ${ }^{917}$ In May 1987, Commander Yusuf Kuwa Makki, a Nuba politician came to the Nuba Mountains and the first military confrontation between the Nuba battalion of the SPLA and the army of the government took place in June at Rimla, an area to the south of Tira Limon district. There were further engagements in Um Dorein and Um Dulu, but the main purpose of the incursions was to mobilise the recruits at Achiron Mountains to volunteer for the SPLA. Small scouting groups were sent throughout the southern and eastern Nuba Mountains. In January 1989, a combined six battalions called 'New Kush Division', under the command of the same Yusuf Kuwa Makki, again entered the Nuba Mountains region and attacked the government forces at different places in the region. Makki promulgated to the Nuba that: "We the Nuba have tried politics with the Muslim Arabs and their unstable political ideologies starting from Mahdism, Sudanese Socialist Union and Islamism, but nothing is for the Nuba, therefore join the SPLA and SPLM. It is the revolution of the marginalised majority". 918

\subsection{The Sudanese Socialist Union and the shift to Islamism}

The research question how do you want the identity of Sudan to be defined in a national constitution and why do you think so? Some Muslim students answered this question as: "Most people in Sudan have lost trust in the current politicians. The legislature always fails to create a permanent

\footnotetext{
915 Doornbos, Martin et al., op. cit., p. 166.

${ }_{916}$ African Rights, op. cit., p.66.

${ }^{917}$ Ibrahim O, a Nuba Muslim, Omdurman Ahlia University.

${ }^{918}$ African Rights, op. cit., p. 66.
} 
constitution for the people of Sudan". ${ }^{919}$ One student notes: "President Nimeiri did well at first, but proved to be an unstable political soldier in his political ideologies. He captured ... a democratically elected government, under the Islamic sectarian party of 'Mahdism' in 1969 and constructed his single political party, the 'Sudanese Socialist Union' (SSU) to operate in Sudan. ${ }^{920}$ Another student concludes: Under the SSU, the Sudanese people were oriented to 'shout' on the public streets; 'Our Union, Communal, and Freedom'. Gradually, the President shifted us ... from these beautiful slogans, after fourteen years in power to Sharia and forced us to learn a new slogan to shout; 'there is no god, but God and Muhammad is His Messenger".,921

After having taken power in 1969, Nimeiri had lost the religious aspect of his ideological discourse. The Sudanese citizens were taught to sing the socialist ideological national anthem 'Our Union; Communal; Freedom'. ${ }^{922}$ The shift from this to the slogan of Nimeiri's late years 'There is no god, but God and Muhammad is His Messenger' marks the change from the revolutionary ideology based on 'socialism, 923 to the adoption of the extreme religious Islamic ideology, which included forced conversion of the citizens in Sudan. The opposition forces rebuked Nimeiri not for having adopted the Islamic religious slogan, but for having eradicated legally the freedom of religion in Sudan. For instance, the Head of the Muslim sectarian reformist group, the Republican Mahmoud Muhammad Taha was bitterly opposed to the imposition of Sharia as the only legal source in the national criminal and civil judiciaries. Taha argues that the teaching of Islam states "propagate the path of your Lord in wisdom and peaceful advice and argue with them in a kind manner. Your Lord is more knowledgeable of those who astray from His path and $\mathrm{He}$ is more knowledgeable of the guided one", ${ }^{924}$ In reaction, Nimeiri accused Taha of apostasy and assassinated him. de Waal argues that President Nimeiri accused Mahmoud Muhammad Taha an Islamic theologian of the Republicans reformist movement of apostasy. de Waal concludes that,

\footnotetext{
${ }^{919}$ Ibrahim Ahmed Saleh, a Mahas, University of Khartoum: "For me, politicians of Sudan are corrupted; no one is ready to make a permanent and national constitution for all the people. Each presents an objecting constitution to the image of others. Ahmed Ja'fer, a Danagella: "A good constitution comes, when there is a will from the politicians to maintain transparency in democracy, but our politicians are badly corrupted".

${ }_{920}$ Dafala Muhamed, Danaqqla Muslim, Omdurman Ahlia University.

${ }^{921}$ Suleiman Keddir, Omdurman Ahlia University.

${ }^{922}$ Sylvester, Anthony (1977). Sudan under Nimeiri, London: Bodley Head, p. 23.

${ }^{923}$ Ibid.

924 Taha, Mahmoud Mohamed (1987). The Second Message of Islam (Trans.), Abdullahi Ahmed An’Naim, New York: Syracuse University Press, p.131.
} 
under that "an infamous act of fundamentalist barbarity", Nimeiri killed Taha in the Sharia court on 18 January $1985 .{ }^{925}$

For the Christian and Animist students the Sharia displays the Church of Christ as a community which violates the Islamic order that prevents all forms of alcoholic beverages. Under the Sharia, the traditional way of Christian worship is quickly interpreted as a legalisation of alcohol consumption in the Churches of Sudan. ${ }^{926}$ According to Lesch, after the imposition of Sharia, Christian Churches in Sudan argued that the Sharia eliminated freedom of worship. An Italian Catholic priest was accused of having kept communion wine in the parish of St. Joseph in Khartoum. He was flogged in public court known as the 'Court of Complete Justice'. Episcopal, Presbyterian, Evangelical, Catholic Churches and representatives from the staff of Sudan Council of Churches (SCC) established a dialogue with Nimeiri. They wrote a petition document, where they cautioned him to review the application of Sharia. The Church leaders complained that its inclusive application had affected their rights as Christian citizens and placed them at the category of 'second-class citizens. In conclusion, they urged the President to revive the pluralist secular laws that had respected religious equality among the citizens of Sudan. ${ }^{927}$ On the other hand, not only the Christian and Animist students reject the imposition of Sharia in Sudan, but the majority of Muslim students also do not accept it without public debate on the matter. For instance, some Muslim students argue: "You can't apply in the modern world a law that chops of the limbs of those who steal". ${ }^{928}$ Another one claims: "A thief does not steal, for the sake of stealing; the state does not offer opportunities for him to access food, so I ... don't support the adoption of Sharia, because it cuts their limbs". ${ }^{929}$ One student concludes: "In Sudan poor people sleep without food and can be tempted ... to sneak into the pockets of others, but the Sharia amputates them, so what is the use of it?" ${ }^{930}$ According to Burr, most of civil servants in Sudanese institutions opposed Nimeiri's new directives and tried to unseat him from power through mass demonstrations. On 27 March 1984,

\footnotetext{
${ }^{925}$ de Waal (2004), op. cit., p. 81.

${ }^{926}$ Ker Dim Akol, a Dinka Christian Animist, University of Juba: "Islamic constitution treats our Christian Church as a centre of an alcoholic group and beats us". Tier Ngor, a Dinka Christian Animist, University of Juba: "The Islamic constitution projects us to the level of second-class citizens, where the Church and traditions are uprooted"..

${ }^{927}$ Lesch, op. cit., p. 55.

${ }^{928}$ Y A Hawazama, University of Khartoum.

${ }^{929}$ M H D Shaiqqiyyia, University of Khartoum.

${ }^{930}$ A O M Ja'alei, Omdurman Ahlia University.
} 
three thousand medical doctors submitted their resignation in protest of unethical amputation of limbs to poor people in the country dominated by poverty. ${ }^{931}$

The amputation of human limbs within the judiciary system of Sudan divides the Islamic law, the Sharia at two categories. First, its adherents consider it as a worthy law that regulates the citizens of Sudan into the categories that abnormalise a healthy person into the new category of handicap by amputating the limbs, while they are un-sick, but healthy. In contrast, those who object its adoption in the Sudan political environment see it as a worthless law inserted into the public institutions in an organised legal order and they strive to resist its application in the country's judiciary system. Its adoption, however, in the judiciary makes them categorise such a judiciary as a system that regulates laws and moral codes towards 'abnormality' of human limbs in the social institutions of Sudan. According to Lesch, after the rejection of doctors to the amputation of limbs, Nimeiri dissolved the 'Union of the Doctors' jailed many of them and closed down University of Khartoum, where serious massive demonstrations were taking place. He finally imposed emergency law on 29 April 1985. At the same time, the SPLM intensified its rejection to Sharia and overrun some army garrisons. Nimeiri tried to obtain military support from the USA in order to crush the rebellion, under John Garang. He approached the USA with the ideological clarification that tried to project the political violence between him and the Southern insurgents as was a war between the capitalist religious believers versus the Southern Communist atheists supported by Ethiopia. Some US officials from the State Department were not satisfied by this claim and acknowledged that the war was not ideologically instigated by Ethiopia. ${ }^{932}$.

\subsubsection{Nimeiri's disagreement with the Islamists}

Some Muslim students present their views on the Islamic system in Sudan as one of them states: "Islamists in Sudan are political opportunists in our social structures. There is no anyone among them who applies Islam as it is in the Quran and that makes them change their visions. At last, we fail to produce a unified constitution that protects individuals." 933 another notes "At difficult political turmoil, Nimeiri resorted to Turabi to use his defunct Islamic Charter Front (ICF)

\footnotetext{
${ }^{931}$ Burr and Collins, op. cite., p. 17.

${ }^{932}$ Johnson (2002), op. cit., p. 66.

${ }^{933}$ S A M Muslim Nuba, Omdurman Ahlia University.
} 
movement, but Turabi subordinated the SSU and wanted to apply his Islamic extremism and that led to his detention with other members of his ICF". ${ }^{934}$

Students continue: "Nimeiri was an opportunist soldier". He brought Turabi, the Islamic ideologue of the ICF into his system, SSU to support him". 935 "When Nimeiri realised that his political party, the SSU could not co-exist together with the ideology of Islamic fundamentalism, he resorted to crush the ICF which was an organisation that collaborated with him to impose ... Sharia by detaining their leader Hassan Abdullah Turabi. This Islamic ideologue advocates the Islamic constitution, where Sharia is the source of everything without any reference to SSU". 936 One of the students concludes that: 'Nimeiri was an 'opportunist soldier' he detained Turabi in order to restore political trust from the moderate Muslim majority in the North as well as the pagans from the South, but this new method was too late to rescue him". 937

Analysis to the instability of Nimeiri ideology unfolds that a political demagogue can exploit political circumstances with the expectation that may solidify his political power to remain intact; however, that is not possible always, due to the parallel visions of political ideologies. According to Lesch, on 25 September 1984, Turabi organised with his members of the ICF the first anniversary of the Sharia adoption in Sudan. He collected his Islamists and marched on the streets of the capital city, Khartoum with the slogans that projected the ICF as an independent body from the SSU, but standing only in support of the implementation of the Sharia in Sudan. In reaction, Nimeiri declared that his organisation, the SSU was the only legitimate party. He defined his identity in confrontation of Turabi as a "fighting imam" facing Turabi a "scholarly imam" plotting to replace him from power. ${ }^{938}$

On 10-11 March 1985, Nimeiri alleged the Islamists of having attacked the secularists and the Christian and Animist Students from the South at the University of Khartoum and arrested more than one hundred of them, including Turabi. In the South, the SPLA and SPLM were advancing against his installations of power and had forced the American company, Chevron to suspend its oil operation in the South as well as the French company that was digging the Jonglei Canal. At that time, Sudanese formed political alliance to oust Nimeiri from power. ${ }^{939}$

\footnotetext{
${ }^{934}$ Ahmed Z. Muslim, University of Khartoum.

${ }^{935}$, Sakina Ja'afer, a Shaiqqyyia, Omdurman Ahlia University.

${ }^{936}$ Nahd Ahmed, Muslim Nuba, University of Khartoum.

${ }^{937}$ Muddathir Ali, Shaiqqiyyia, University of Khartoum

${ }^{938}$ Lesch, op. cit., p. 57.

${ }^{939}$ Hale, Sondra, op. cit., p. 191-192.
} 


\subsubsection{National Alliance for National Salvation}

After the execution of Mahmoud Muhammed Taha, under the allegation of being an apostate, Sudanese professionals at different institutions were furious about that political killing in the name of Islam and formed a new association on the very day, under the name National Alliance for National Salvation (NANS). The aim of that association was focused on the removal of Nimeiri from power through civil disobedience in all public institutions of Sudan. ${ }^{940}$

The alliance in Khartoum established contacts with some Sudanese professional workers in the Gulf Arab countries and the SPLM. Later the SPLM and the other Islamic sectarian Northern political parties, Umma, DUP, secular Sudanese Communist Party (SCP) and other members of the NANS organised a political meeting in London. The meeting discussed what form of a constitution would be adopted, if Nimeiri was overthrown. The participants agreed unanimously on a written charter that called for the retrieval of the provisional constitution of independence in January1956, which allows political and religious freedom of expression in public media, beliefs, independent judiciary and maintenance of order and rule of law. It also called for the restoration of the democratic system based on pluralism ${ }^{941}$

In the opinions of some Christian and Animist students, the application of the Sharia provoked the popular uprising. It was a revolution of those who were seriously dissatisfied with the application of that law in the state. The TMC turned down the hope of the people and acted in favour of the NIF by avoiding its cancellation. ${ }^{942}$ One of them concludes that "The TMC captured the revolution of the victims of Sharia who had wanted it to be rescinded, but the army generals who exploited the situation were not members of NANS. So, they decided not to drop Sharia". ${ }^{943}$

The claim of students that if the generals were members of NANS, they would have abrogated the Sharia is flawed. First, the charter which the SPLM ratified with the political North hung on superficial terms of democratic pluralism without reference to the underlying complex values of a democratic system. For instance, the charter refrained from addressing the issue of interlaced Islamic-Arab identity in opposition to the Christian and Animist secular identity. These two contesting definitions of Sudan's identity are basically responsible for the current instability of the

\footnotetext{
${ }^{940}$ Simone, op. cit., p. 46.

${ }^{941}$ Salih, Kamal Osman (1990, June). "The Sudan, 1958-9: The Fading Democracy, the Journal of Modern African Studies, Vol. 28, No., 2, p. 199.

${ }_{942}$ Mathok Amet, a Dinka Christian Animist, Omdurman Ahlia University.

${ }^{943}$ Sabah Muhammed, a Nuba, University of Khartoum.
} 
country. The London charter reaffirmed the necessity of the resumption of the democratic multiparty system of pluralism with its accompanying values of freedom of worship and expression, but there was no reference to the place of Sharia in the charter. Second, the composition of the TMC embodied representatives of the Southern Christians and Animists. Among the fifteen senior generals that composed the TMC, two of them that included Fabian Agamlong Guem and James Loro were both Christians from the South. ${ }^{944}$ The two Christians remained unconcerned about the inequality that Sharia created among the people of Sudan. According to Sumbeiywo, the dominant Christian organisation, the SPLM calls for the complete legislation of the secular constitution, instead of Sharia in order to permit freedom of worship equally to all citizens of Sudan. ${ }^{945}$ Third, the NANS was an unholy alliance, since its composition embodied Sadiq Al-Mahdi, the Head of the Umma party. Sadiq rejected the adoption of the Sharia, when he was out of power and refused to revoke it, when he came back to power in 1986, until the current President Al-Bashir unseated him from power. ${ }^{946}$

The role of Sadiq Al-Mahdi towards the conflicting systems of the secular law and the Sharia remains a controversy among students of Sudan. In regard to the question "How do you want a national identity of these regions to be defined in a national constitution of Sudan and under what system suits Sudan best and why do you think so?" Some students claim that democratic pluralism is the 'best' system, but its application in Sudan always reflects family democratic dynasty, where Sadiq never comes up with anything new except for the building of Islamic Arab culture in Sudan. ${ }^{947}$ One student states "Democracy is the best system, but those who apply it mostly come from the ... corrupted families that exploited the people of Sudan in many ways including religion, Islam to equip themselves with wealth. These political groups come from families that have (sic) practiced illegal means to access wealth from the citizens of Sudan. ${ }^{948}$ One Muslim student concludes that families whose grandfathers have practiced injustice, including slavery against their own citizens are not supposed to lead the nation, but our ignorance and poverty blinded the Islamic North and brought back Sadiq Al-Mahdi to power in April 1986. ${ }^{949}$

\footnotetext{
${ }^{944}$ Lesch, op. cit., p. 63.

${ }^{945}$ Sumbeiywo, Lazaro (2006). The Mediator General Lazaro Sumbeiywo and the Southern Sudan Peace Process, Nairobi, Kenway Publications, p. 37.

${ }^{946}$ Lesch, op. cit., pp. 55, 80.

${ }^{947}$ Samia Awad, a Fur, University of Juba.

${ }_{948}$ Madina Hamed, Shaiqqiyyia, Omdurman Ahlia University.

949 Thon Malual a Dinka, University of Upper Nile states "In civilised world of the West, families of those whose fathers committed crimes against their nations are not seen as worthy to lead. In Sudan always, Sadiq is back in power
} 
Al-Mahdi is the grandson of Abdul Rahman Al-Mahdi who resisted the British attempt to set the Animist slaves from the South free. ${ }^{950}$ However, the claim of rejecting some elite in assuming power, because of unethical means of wealth in the Third World is a very remote goal to be reached in Sudan. It can happen in the Western institutions, where history of politicians and sources of their wealth are kept in memory from one generation and transmitted diachronically to another generation. Mann observes that in some true democratic systems in the West, some social and political groups trace the history of contesting candidates for power. Children of dictators, totalitarians, theocratic and despotic systems experience rejection from people in taking power in nation-states. $^{951}$

The interest of some students in removing Al-Mahdi from politics, because of being from the family alleged of slavery in the Black Animists from the South is not the major concern today. The primary concern is the political role the Prime Minister, Al-Mahdi played towards the drafting of a Permanent Constitution of Sudan, when he resumed power from 1986 and onward. One Christian Animist student explains: "We had expected Al-Mahdi would come to power and restore the equality of the citizens before the law, regretfully, instead he developed Islamic fundamentalism, during his tenure as a Premier in power. ${ }^{952}$ Another Muslim student states: "Sadiq as a Premier totally refused to restore the rights of the African traditionalists and Christians ... to live as equal citizens with the Muslims, under a secular constitution by rejecting the earliest political attempts of the SPLM to nullify Sharia." 953 Further, another student claims that: "Al-Mahdi declared that the Muslim majority has a right to apply Sharia, if they want it and the minority of the Animists and the Christians must accept the choice of the majority and live with it. ${ }^{954}$ A Nuba Muslim student at University of Khartoum concludes: "There is no Muslim Arab in power in Sudan that can make a constitution that revokes Islamic law, unless the SPLM dictates such a leader to act".955

Dictation of political terms came in 1989, when the SPLM, under Garang met in Ethiopia with the leader of the DUP, Muhammed Osman el-Mirghani and reached a consensus of 'freezing' the Sharia in their historic document the 'Sudanese Peace Initiative' (SPI) signed in Addis Ababa in October 1989. In Khartoum, Umma, SCP, National Party (NP) of the Nuba and the Southern parties

by the Northern Muslims without consideration of the bad history of his grandfather who adopted enslavement to get wealth".

${ }^{950}$ See Idris, op. cit., p. 54.

${ }^{951}$ Mann, Nicholas (1993). Atlas of Renaissance, London: Cassell Villiers House, p. 23.

952 Thomas Mou, a Dinka, University of Bahr el-Ghazal.

${ }^{953}$ Kuol Kong, University of Upper Nile.

${ }^{954}$ Sumbeiywo, op. cit., p. 69.

${ }^{955}$ Madina Hamed Kutum, University of Khartoum 
accepted the SPI contents and were scheduled to endorse it in the NCA. In reaction, the NIF, under Turabi instructed its cells in the army to abort the voting. Brigadier Al-Bashir seized power on 30 June 1989, in a bloodless coup d'état only twenty-four hours, before the Members of the NCA could vote on the 'freezing' of the Sharia and revived the 'Islamic fundamentalism' system. He called his coup the Revolution of National Salvation (RNS). ${ }^{956}$

Two hypotheses can provide for us the nature of the Sudan's Armed Forces (SAF) and the nature of the 'Islamic fundamentalism' in accessing power. First, the emergence of 'Islamic fundamentalism' through the might of the SAF suggests the dominance or the influence of officers of the Muslim fundamentalists in the SAF. There is no logic that soldiers in national barracks could acquiesce to the coup that disrupted the democratic legislature with the intent to insert Islamic ideology, if it was not under the control of Muslim fundamentalists. This hypothesis directs us to scrutinise the structure of the 'Revolutionary Command Council' (RCC) that was headed by the Brigadier Al-Bashir and his first objective of the coup over the National Television of Sudan (NTS). In fact, the members of the RCC were fifteen and three of them were Christians from the South and the rest were Muslims. One of them, Colonel Martin Macuie Malual Arop explained over the NTS that: "Our revolution is entirely disconnected from Islamic fundamentalism; the fifteen of us represent the national characters of the SAF with complete aim to save the people of Sudan from the dysfunctional institutions of sectarian democracy and corruption. If it proves later that there is an Islamic religious ideology in the revolution that aims to transform our national identity into the Islamic image, then some of us would immediately quit'. 957

Quitting of his own free will was hardly difficult for Martin. On 11 March 1992, Colonel Martin was discharged from the RCC. Subsequently, in October 1993, the 'Council of Forty' (CF) members composed of the NIF officers and its civilian technocrats chaired by Turabi worked in secret to dissolve the RCC and accommodated its Islamic adherents in sovereign positions. ${ }^{958} \mathrm{Al}-$ Bashir, however, concealed his aims of the coup in a communiqué aired out 30 June 1989. According to Jamal, Al-Bashir centred his revolutionary objectives on the first day of his revolutionary communiqué on the national media. He claimed that the objective of the coup was to

\footnotetext{
${ }^{956}$ Warburg (2003), op. cit., p. 206.

${ }^{957}$ Interview on the Sudan National Television with Martin Macuie Malual Arop, a member of the Revolutionary Command Council on 13.3. 1991.

${ }^{958}$ Lesch, op. cit., pp. 115-116.
} 
eradicate the 'corrupt' system of democracy and revive unity among the people of Sudan. ${ }^{959}$ In contrast, Alex de Waal argues that the NIF soldiers captured power and supported a consistent economic corruption with businessmen in national institutions. The public assets of the state were plundered through privatisation. Promotions were based on personal qualities and connections and not on an objective qualification process. de Waal concludes that the regime became unpopular and people started to ask, why a corrupt system tried to teach them virtue and social morals. ${ }^{960}$

Approximately, two years after of the revolution, Al-Bashir commenced to unfold his revolutionary identity and aim contrary to the statement that was spread in the public media in his first communiqué. According to Voll, Al-Bashir explained: "We upheld the Islamic trend from the beginning. An Islamic organisation was created in the Armed Forces ..., since 1971. When the revolution began in June 1989 ... the leadership of the NIF met and decided ... to join the authorities. We needed a number of their cadres ... We are trying to apply the Islamic texts gradually and intend to establish an Islamic state in Sudan ... We have programme for comprehensive daw'a (religious propaganda) as a new civilisation project". ${ }^{961}$

President Al-Bashir provides us with a comprehensive explanation on how Muslim fundamentalists propagate their aim to build an 'Islamic stat'. First, a single person or a few of them can infiltrate the border of a certain institution; however, since the penetrated institution might not embrace the ideology, then he conceals the aim and the identity, until a certain degree of transformation to Islamic identity in the penetrated institutions is reached. At this phase, the fog of the mysterious identity and the aim are both removed and the task of implementation officially begins. Generally, the synopsis of this practice resembles a tick, a small insect that penetrates the skin of an animal and absorbs blood within. ${ }^{962}$ Second, an ideological Muslim cloaks his Islamic ideology in an irrelevant subject-matter such as 'corruption' in order to cause nostalgia in the audience for an institution, while working gradually within those public institutions to emasculate them and embed the hidden ideological aim. Third, an Islamist ideologue is an antagonist of the democratic pluralistic system, where the majority outweighs minority ideology. At this stage, he

\footnotetext{
959 Jamal, Abbashar (1991, September). "Funding Fundamentalism: The Political Economy of an Islamist State", Middle East Report, Vol. 172, p. 15.

${ }^{960}$ de Waal (2004), op. cit., p. 85, 95.

${ }^{961}$ Voll, John O (ed.) (1991) Sudan: State and Society in Crisis, Bloomington: Indiana University Press p. 59.

${ }^{962}$ Vanderhoofforschner, Karen (2003). Everything You Need to Know about the Lyme Disease and Other Tick-Borne Disorders ( $2^{\text {nd }}$ ed.), New Jersey: John Wiley \& Sons Inc. p. 2, 5, 18.
} 
captures a democratic majority system through a mighty army or violence as a means to impose his vision of transforming national institutions towards an Islamic state.

According to Rifat, Muslim fundamentalists claim that the establishment of the Islamic state does not require a majority; it is a work of minority believers. Islam as a religion of God does not gain victory through majority, since its historical experiences show that a small number of believers routed the majority with the permission of God to execute His divine order that focuses only on the foundation of an Islamic society ruled by Sharia. ${ }^{963}$

The experience of a state that applies Sharia radically into national institutions constructs citizens into social classes in terms of religions, where non-Muslims become second-class citizens. Such people falling into the second category of citizenship experience political marginalisation, even, if the Islamic legislature has legislated laws that protect their uniqueness. Those legal laws remain in the constitution and cannot open up equal opportunities for all citizens within an Islamic state. According to Hemmasi and Provok, the Iranian Revolution of 'Islamic fundamentalism' seized power in 1979 and produced a constitution that relies on the sources derived from the Quran. This constitution recognises the non-Muslim Iranian minority, but in practice, this minority occupies the status of second-class citizens residing, under the protection of the Muslims' sovereignty. Today; the Iranian Jews endure all forms of power and wealth marginalisation. They cannot access employment opportunities as equal citizens with the Muslims and as a result, they engage themselves in petty jobs and professions. ${ }^{964}$.

\subsection{Ideology of the civilisation project}

According to social theory, a ruling group that adopts a racial ideology within the territory of a state may transform it into a set of beliefs to justify the rejection of the status quo with the minority in order to legitimate its interest. ${ }^{965}$ Some students including Muslims, Christians and Animists claim that radical Islam would have not succeeded in Sudan in 1989, under the democratic system of pluralism. Turabi observed that the existing political democracy was a barrier to the transformation

\footnotetext{
${ }^{963}$ Rifat, Sid Ahmed (1989). Munathat Al-Islamia el-Zaej fil Sabaeennaat, Arabic, The Islamic Anger Organisations of Seventies, Cairo: Madbuli, pp. 137, 146-147.

${ }^{964}$ Hemmasi, Mohammad and Provok, Carolyn V. (2002). "Demographic Changes in Iran's Officially Recognized Religious Minority Population since the Islamic Revolution”, African and Asian Studies, Vol. 1 No. 2, p. 63.

${ }^{965}$ Robertson (1981), op. cit., p. 289.
} 
of Sudan to an Islamic nation-state. ${ }^{966}$ According to Sidhamed and Ehteshami, Turabi introduced his ideological discourse of building an Islamic state to Sudan's national army, which collaborated with him and seized power from the democratically elected government. Having gained power, he commenced to transform all social, political and cultural institutions of the state to radical Islamic fundamentalism, where the Sharia became the source of law for every single activity of the citizens. Turabi claims that the state is not nationalistic, because the ultimate allegiance is owed to God, and to the community of Islamic believers. This allegiance of the state to God negates the concept of its territorial sovereignty. It is subject to the higher norms of the Sharia as a 'civilising project' representing the Will of God among Muslim believers. Sidahmed and Ehteshami conclude that, during that time, every institution was stocked with the members of his organisation, the NIF to delist any group resisting the trend of the tawajha el-hathari (civilising orientation project) equally known as the 'civilisation project' based on Arabism and Islamism in Sudan. ${ }^{967}$

For Turabi, Sudan has no territorial sovereignty, since nationalism has only two purposes: First, God and second, a community of Muslim believers residing in the territory. According to Petterson, by 1994, Turabi had invited extremist Islamic organisations of Al-Qaeda, Hezbollah of Lebanon, the Palestinian organisations of the Islamic Jihad and the Islamic Resistance Movement (HAMAS), Islamic, Jama'at Al-Islamiyya of Egypt, and others from Eritrea and Algeria to come to Sudan and built their institutions. ${ }^{968}$ If the aim of the invitation to these Islamic organisations is related to the definition of Islamic nationalism, then what was the purpose of inviting Ilich Ramirez Sanhez, known as Carlos the Jackal, a non-Muslim originally from Venezuela convicted for several murders including, three men at the Organisation for Petroleum Exporting Countries (OPEC) in Vienna 1975? The Government of France wanted Carlos for the alleged crime of terrorism, committed in its territory. ${ }^{969}$ For some students, Turabi faced difficulties in his methods of implementing this ideology on the multi-cultural and religious society of Sudan. This claim is widely expressed in the answer to the question, how do you want the identity of Sudan to be defined in a national constitution? Christians, Animists and also some Muslim students provide many reasons of their

\footnotetext{
${ }^{966}$ Wadia Ahmed Awad, Beja (Hadendawa), University of Khartoum "Under democratic debate, Sharia would have not been passed in the parliament. So, Turabi resorted to the army and took power to legalise Sharia".

${ }^{967}$ Sidahmed, Abdel Salam and Ehteshami, Anourshiravan (eds.) (1996). Islamic Fundamentalism, Oxford: West view Press, p. 193.

968 de Waal (2004), p. 97, 106.

${ }^{969}$ Petterson, Donald (2003). Inside Sudan Political Islam, Conflict and Catastrophe Revised and Updated, Oxford: West view, pp. 117, 113.
} 
rejection of the foundation of an Islamic state in Sudan, such as: "I want the identity of Sudan to be defined in a public constitution as a diversified pluralistic one; such a constitution respects my religions as a Dinka." ${ }^{970}$ According to other students Turabi rejected such a constitution and legitimated discrimination by imposing Sharia in order to force the non-Muslims to become Muslims constitutionally. ${ }^{971}$ One of them concludes: "Those of Turabi never wanted the existing religious diversity. Hence, they legitimated Islamisation of the non-Muslims in the country in an Islamic-classical approach that legalizes the use of force in conversion. ${ }^{972}$

\subsubsection{De jure discrimination in Sudan}

Sociologically, de jure discrimination is referred to as legalised discrimination encoded in the national laws of a state. ${ }^{973}$ In general, Christian and Animist students in Khartoum argue that the current government, under President Al-Bashir discriminates against non-Muslims. The exiting legal system continuously applies an Islamic constitution that rejects the equality of a Muslim with an Animist or a Christian in Sudan. It allows a non-Muslim to change his religion to Islam, but not a Muslim to convert to another religion. In this sense, Christians and Animists have no equal value or status or identity in Sudan. ${ }^{974}$

Some students argue as: "I hate an Islamic constitution. Imagine, when Al-Bashir took power and applied his monolithic Islamisation, some Christians and Animists were converted into Islamic faith ... and we had no complaints against their conversion. But when some Muslims in Omdurman were converted to Christianity, they were accused of apostasy. ${ }^{975}$ But in the view of another Muslim: "Apostasy must be applied, since our country is an Islamic state." ${ }^{, 976}$ In reaction to the apostasy another student argues: In Sudan, a Muslim is prevented legally not to convert to Christianity or Animism. This shows my religion is not protected by the state as an equal citizen with a Muslim". ${ }^{977}$ Others continue to claim: "Islamic constitution of Al-Bashir eradicates me from the territory as a citizen, because it claims that I am residing within the Muslim state under its

\footnotetext{
${ }^{970}$ Alie Ater, a Christian Animist, University of Juba.

${ }^{971}$ Mohammad Mohammad Adam, Zagahwa, University of Khartoum "Before, Turabi rejected a diversified constitution in Khartoum, but I like it, because, it preserves individuality in cultures".

${ }_{972}$ Al-Nur Hamed, Nuba Muslim at Omdurman Ahlia University.

${ }^{973}$ Robertson (1981), op.cit., p. 295.

974 Athur Mathiang, a Dinka, University of Juba.

975 Anthoney Akol, a Dinka Christian Animist, University of upper Nile.

${ }^{976}$ Al-Saleh Ibrahim, University of Khartoum.

977 Alor Baget Deng, a Dinka at University of Juba.
} 
protection, so I am a mere second class citizen under its protection." ${ }^{978}$ Finally, an Animist Dinka complains: "I as a Jieng Animist, under ... religious constitution of Islam, Christians and Jews are the dhimmis who would live in the claimed Muslims territory of Sudan, because the moral due of Islam protects them. Yet, we are not equal citizens with the rest of Muslims. For the Animists like me, we are the outlaws, since we are not within the category of dhimmis". ${ }^{979}$

In fact, Article 139 (b) of 1998 Sudan's constitution states: "All individuals have freedom of conscience and religion". ${ }^{980}$ Ye according to Amnesty International reports, some provisions within the Sudanese law constitute discrimination against non-Muslims in the country. The Criminal Act of 1991 permits the non-Muslims to convert to Islam, but not vice-versa. This act defines a Muslim that changes religion as an "apostate", which is a crime a punishable by death in Sudanese criminal courts. $^{981}$

The permission for conversion to non-Muslims, but not Muslims establishes two dimensions. First, the law discriminates against the Muslims by prohibiting them to practice what is allowed to the non-Muslims. Second, it accelerates the assimilation of the Animists and the Christians in Sudan to Islam as the aim of the Government of Sudan. Human Rights Watch (HRW) reports that the Government of Sudan, under the NC of Al-Bashir has laid down conditions with the aim to assimilate the heterogeneous composition of religions and ethnicities to its version of Arabism and Islamism. Its legislature legitimates the Sharia to be the only free law in the regions of North Sudan. Under that law, there is no freedom for a Muslim to change to other existing religions in the country. For example, the Nuba school teacher, Mekki Kuku, who denounced Islam and converted to Christianity, was to be tried for apostasy, an allegation that leads to the death penalty in the Northern Sudan. ${ }^{982}$ De jure discrimination emerges also through the constitutional adoption of Jihad as an obligation of the citizens of Sudan. A Nuba Muslim student at University of Khartoum states: "The National Islamic Front, NIF, under Turabi with his old friend President Omer Hassan Al-Bashir in power introduced exclusively an Islamic system that kills the Muslims in Sudan, since 1989, until the present day". ${ }^{983}$ Another student argues: "By then, we thought the system adopted

\footnotetext{
${ }^{978}$ Mar Kwal, a Nuer Christian Animist, University of Upper Nile.

${ }^{979}$ Bak Dhal, University of Juba.

${ }^{980}$ Constitution of Sudan (1998). Constitution of the Republic of the Sudan Entered into Force July 1998, p. 25.

${ }^{981}$ Human Rights Watch (1999). New Islamic Penal Code Violates Basic Human Rights, 4/91, 15, pp., 3.300/1.95.

${ }^{982}$ Human Rights (1998). HRW Background Paper on the 1998 Famine in Bahr el-Ghazal, Sudan http://www.hrw.org/campigns/sudan98/sudfam.htm.

${ }^{983}$ Ja'afer Sadiq.
} 
Jihad to kill the non-Muslims at the South, Nuba Mountains and Ingessana Hill, but it turned out that we the Nuba Muslims were ... excluded from the conference, where Jihad was discussed and declared in El-Obeid city. The mystery of excluding us from the conference became clear later in Nuba Mountains, when Jihad was applied against us in the region, irrespective of our being Muslims". ${ }^{984}$ Article (4) of the Constitution of 1998 binds every Sudanese citizen to join Jihad as it states: "Defence of the motherland is an honour and Jihad is a duty". 985

The constitution of 1998 revived and legitimated the Islamic term 'Jihad' and defined it as an obligation to the people of Sudan without a reference to the status of the non-Muslims. The African Rights reports that the last Jihad in Sudan was officially organised and inaugurated in the capital city of Northern Kordofan State, el-Obeid in 1992. According to the resolutions of the conference attended exclusively by Muslim Arab members, the Muslim Nuba people and the 'Christian Animists' were defined to be in opposition to the government, being supporters of the SPLM and as such were 'apostates'. Under this definition, it was concluded that a Jihad would be adopted as a legitimate religious approach in assaulting the opposition, the SPLA forces within Sudan. ${ }^{986}$

In essence, Jihad is a Muslim religious term for the internal religious struggle for purity as well as external defence of religion. Today, it has become excuse to kill political opponents. ${ }^{987}$ Some Muslim students maintain that Muslim 'fundamentalists' of Sudan of NC of Al-Bashir have rejected a constitutional system that would allow the people of Sudan live as equal citizens before the law. The government constantly adopts a discriminatory religious Islamic orthodoxy appealing to the minds of the Muslims to fight a war against the Christians, Muslims and Animists of the South, under the Jihad. One student states: "During the war, Al-Bashir system entirely deceived the Muslim fundamentalists that the aim was to solidify an Islamic system in Sudan. For this reason, it rejected a pluralistic constitution that preserves the rights of all citizens". 988 Another argues: "My own observations proved that the aim was to appeal to the minds of those Muslims to assist his regime that was threatened by the Christians and Animists of the South". ${ }^{989}$ Finally, another notes: "Al-Bashir adopts the radical Islamism of Jihad, because, he wants Muslims to see that Islam is

\footnotetext{
${ }^{984}$ Al- Nasser Hassen, University of Juba.

${ }^{985}$ Constitution of Sudan (1998), op. cit., p. 23.

${ }^{986}$ African Rights (1995), op. cit., p. 289.

${ }^{987}$ Kelsay, John (1993). Islam and War a Study in Comparative Ethics, Westminster: John Knox Press. Today, Muslim leaders advocate jihad as a means to launch war against non-Muslims and Muslims that hold different opinions in political structures, p. 11.

988 Adelaan Muhammed, Shaiqqiyyia, Omdurman Ahlia University.

${ }^{989}$ Saburi Amir, Fur, University of Juba.
} 
under a threat from Christians and pagans. For me, Christians and Animists could be sustained peacefully, if a non-Islamic constitution operates in Sudan". 990

The process of taking the name of religion, Islam into war is an exploitation of this religion. First, it sanctifies the political violence to religious one between the Muslims and the Christians in Sudan and in essence, there is no God inviting the Christians to kill the Muslims neither there is a God urging the Muslims to kill the Christians in Sudan. Instead, political warlords masquerade as religious figures, before God and make people kill themselves in the name of God as if there were direct telephone communications between them and God. This ideological discrimination transforms religion into the property of a political leader. It is religion that is used to line up warriors to fight the political dissidents. Addressing the seminar organised by Haram Strategic Studies in Cairo, Egypt, Nafi Ali Nafi, Presidential Assistant and Deputy President of the ruling party, the NC states: "Islam has been the target of its enemies in Sudan, but we are for God service and we have Jihadists to defend it from those elements." 991

\subsubsection{Organisation of Jihad and conflict of imams}

Some Muslim students from Nuba Mountains argue that 'Muslims, Christians and Animists in Nuba Mountains have developed collective political consciousness as the indigenous people of the land. This public consciousness helps them to resist the political dominance of what they called Jellaba or Muslim Arab traders and Administrators. In their views, the Jellaba in Nuba Mountains exert their wealth to divide the fabric relationship that existed among the Nuba people by placing religious borders between them. They claim that the Jellaba tell the Nuba Muslims to keep away from the Nasari (Christian) or Nasareen (Christians) and the Animists in Sudan, but they reject this division and have effectively participated in the war against the Jellaba exploitation of the people in the name of the Islamic religion.

Students' arguments begin as: "In the Nuba Mountains, we know that the Jellaba use their wealth to divide us into categories of the Nassari Nuba, Muslim Nuba and Animist Nuba, but we do not want these categories, after all, we are all Nuba". ${ }^{992}$ However, another one asserts that: "We the Nuba are well aware of 'divide and rule' in the name of Muslim Nuba and Christian Nuba. This

\footnotetext{
${ }^{990}$ Ashref Hussien Ali, a Fur, University of Khartoum. Adelaan Muhammed, Shaiqqiyyia, Omdurman Ahlia University. ${ }^{991}$ Sudani (2008 September, 6). "Nafi Ali Nafi fil Misser, Nafi Ali Nafi in Egypt", Arabic Newspaper, Sudani, Issue No. 961, p. 1.

992 Helam Osman, Omdurman Ahlia University.
} 
clear understanding made us join the SPLM, since the time of its inception." $" 993$ Yet another adds "Our union is very strong, we emphasis only our political identity, the Nuba, whether you are a Muslim, Christian or Animist, it does not matter among us. This is why we registered as the marginalised Africans with the SPLM. ${ }^{994}$ But another Nuba comments: "In reaction to this choice the Jellaba under Al-Bashir was angry and accused us of apostasy, because of our unity with the SPLM. For them, SPLM is an organisation of pagans who intend to wipe away Islam and the Arabs from Sudan. That is not true; our SPLM is composed of peace-loving people as our late leader Dr. John Garang loved all the people of Sudan from Halfa in the far north to Numuli in the south. It was for this reason we ... became members of the SPLM". ${ }^{995}$ Finally, one Nuba concludes: "W joined the SPLA/M to claim our rights from the Jellaba and under Al-Bashir, they reacted and defined us as a group against Islam and sent us their Mujahedeen (Islamic holy warriors) to kill our parents, sisters and brothers in the Nuba Mountains". ${ }^{996}$ The students continue to claim that in reaction to this unity: "The Jellaba from the capital city, Khartoum reject our political unity as the 'marginalised Africans majority' and define our unity as a deviation from the Islamic religious inspiration. ${ }^{997}$ Under this definition, another Nuba states: "our mothers, fathers, brothers and sisters in the jurisdiction of the SPLM were declared apostates". 998 One student concludes that "What is very strange; the imams that declared Jihad were Muslim Jellaba from the government side. We the Nuba ... have our pious and devoted imams. If it was true, that our religion, Islam was under threat, then why was the selection of imams based on race (Jellaba), instead of us all as Muslims.

Something suspicious was there and not the religion, Islam". 999

A UN Rapporteur investigating human rights and the Jihad, Gasper Biro compiled a report on the methods the imams adopted in support of the government against the opposition. The most striking part of the Biro report was the deliberate religionisation of the war. The government discussed the war with six Arab Muslim imams. Biro concludes that the Muslim religious discussants evaluated the development of the violence in the country and agreed to define it as a war between the

\footnotetext{
${ }^{993}$ Nassera Ibrahim, University of Juba.

${ }^{994} \mathrm{~T}$ A University of Juba.

${ }^{995}$ Zubeir Hashim, a Nuba, University of Juba

${ }^{996}$ Anur Mohammed, Nuba University of Juba.

${ }^{997}$ Fahima Muhmmad Hashim, University of Khartoum.

${ }^{998}$ Muhasen Ahmed al-Thou, Omdurman Ahlia University.

${ }^{999}$ Hager Abdullah Hamed, Omdurman Ahlia University.
} 
Southern infidels supported by the apostate Muslims against the Islamic government. ${ }^{1000}$ Six sheikhs or imams wrote and signed the fatwa that reads "The rebels in the south Kordofan and Southern Sudan started their rebellion against the state ... and declared war against the Muslims. Their main aims are killing the Muslims, desecrating mosques, burning and defiling the Quran, and raping Muslim women. In doing so, they are encouraged by the enemies of Islam and Muslims. These foes are the Zionists, the Christians and the arrogant people who provide them with provisions and arms. Therefore, an insurgent who was previously a Muslim is now an apostate; and a non-Muslim is a non-believer standing as a bulwark against the spread of Islam. And Islam has granted the freedom of killing both of them". ${ }^{1001}$

Theoretically, Jihad requires an imam to name for the mujahedeen an Amir, (an Islamic organiser of the mujahedeen) to lead them in battle. ${ }^{1002}$ According to African Rights, the conference that was held in el-Obeid promulgated President Al- Bashir to be the imam of mujahedeen and in turn, AlBashir appointed Husseni, Governor of Kordofan to be Amir of mujahedeen. He also announced each from the Muslim Arab sectional leaders that attended the conference as Amirs at their different domains. ${ }^{1003}$ In answering the question: What is an indecent or immoral practice in the teaching of your religion and how does your religion punish violators? One Muslim student describes Jihad that was declared against the Muslims and Christians in Sudan as 'a serious sin'. He states: "you cannot declare Jihad against other faithful Muslims and Christians. Those who do so for their political mobilisation commit a serious sin in the name of God". ${ }^{1004}$

Jihad was thus used by the Arab Muslims to launch attacks against other Muslims, but non-Arabs in the Nuba Mountains as well as the non-Muslims of South Sudan. In reaction to the declaration of Jihad, the imams and Muslim scholars from the Nuba Mountains dismissed the fatwa that was issued against them from el-Obeid and defined it as an illegitimate Islamic verdict. One of them, Sheikh Ismael Suleiman Al-Nur, imam of Eri mosque argues that: "The enemy has no religion; it burns our mosques and Quran and even, hunts for the imams to kill them. We have heard the version of the Muslim Arab government of Sudan that claims we are helping the kuffar (infidels) and therefore, we too are kuffar ... I have a message for Turabi. I would like to remind him of Surat

${ }^{1000}$ UN Special Rapporteur (1995). Biro: the imams or sheikhs: Musa Abdel Majid; Muhammad Saleh Abdel Bagi; El Qurashi Muhammad el Nur; Nayer Ahmed al Habib; Ismail Abdullah Said Abdullah and Mushawer Juma Sahel, p. 12. ${ }^{1001}$ Ibid.

${ }^{1002}$ Lunde, op. cit., p. 23.

1003 African Rights, op. cit., p. 289.

${ }^{1004}$ Nagela Adam, University of Juba. 
al-Baqrra, where God says: 'He who kills another Muslim intentionally will have everlasting hell'. We are not kuffar, we are faithful Muslims and this Jihad is for stealing, looting and killing discriminately innocent people in Sudan". ${ }^{1005}$.

\subsubsection{Effects of Jihad on civil society}

A great number of Muslim Nuba students from Nuba Mountains and Christian Animist students from the South claim that they have witnessed the role of the government forces, during the time of Jihad."1006 One Nuba describes the application of Jihad as: "It was a disastrous phenomenon that has left terrible and negative effects of relationships between the Nuba Muslims and Jellaba Muslims in Sudan general and Nuba Mountains in particular". ${ }^{1007}$ According to de Waal, the intent of Jihad was to clear off the Nuba Mountains of the Nuba people. Deadly squads were sent to the Nuba community leaders in their villages, while Military Intelligence (MI) arrested the intellectuals of the Nuba in the towns making them to disappear. Khalid Abdel Karim al-Husseini, a younger brother of the governor who had served as security intelligence at the office of the governor and later defected to London in 1993, presents many accusations against the Government of Sudan. Khalid says that, during his terms of active duty, the government collected the intellectuals and the professionals of the Nuba to ensure that the Nuba had no one to speak for them. Contacts to the outside world were sealed off, so that no one would know what was happening to the Nuba people. In 1995, the government evicted many Nuba from their villages to avoid direct international scrutiny of the situation. ${ }^{1008}$

According to the Nuba Muslim students, during the Jihad, the government forces defined many civilian areas as 'villages of apostates' and reduced them to rumble. Their mosques were categorised as being profaned and were incinerated. These areas include Kuada, Kodi, Kucama, Kumu, Toror and Um Derdin, Fama in the Shatt Damam area, Kwololo, Um Muzaria, Hajar elDabib and Lagawa, where Mujahedeen of Arabs massacred ninety-eight Nuba people. ${ }^{1009}$ According to African Rights, during the Jihad against the Nuba, the Mujahedeen launched assaults

\footnotetext{
1005 African Rights, op. cit., pp. 288-289.

${ }^{1006}$ Amdan Idris, a Nuba Muslim, University of Juba: "During Jihad, Muslim Jellaba attacked Nuba villages, killed the inhabitants under allegation that they were supporting the SPLA and their possessions were looted".

1007 Jamila Hussien, University of Juba.

1008 de Waal (2006), op. cit., p. 2.

${ }^{1009}$ Mawai Kuku Jalal, Omdurman Ahlia University: "During the declaration of Jihad against the Nuba, our homes, such as Kuada, Kodi, Kucama and Kumu were classified as villages of apostates and were burnt. Jihad was a disaster to the Nuba villages of Toror, Um Derdin, Fama in the Shatt Damam, Kwololo, Um Muzaria, and Hajar el-Dabib. In one day, 98 people were killed in Lagawa".
} 
on the most populated villages of the Nuba and annihilated them and took cattle and other properties as booty. ${ }^{1010}$

For the Christian and Animist students, Jihad was a scourge to their villages. Jihadists with the government soldiers used to come out from their different garrisons in the South to attack villages and kill people, loot cattle and burn houses. ${ }^{1011}$ According to the Sudanese Human Rights reports, an unknown number of people were killed in ten villages of the African 'Christian Animists' in eastern Upper Nile of the Southern Sudan. The scourge of the attack was, under the category of Jihad. Fifty-nine dead bodies were found in those burnt villages, including the Pastor, Jacob Manyel who was burnt to death. ${ }^{1012}$

Looking at Jihad in relation to the nature of its practice makes one to describe it as a scorchedearth strategy, since it was extensively carried out throughout the areas of the South. For instance, the areas of the Dinka in Gogrial, Abyei and Northern Bahr el-Ghazal of Aweil counties were targeted on the ground by the Mujahedeen, while aerial bombardments targeted the villagers and cattle. Sudanese Human Rights reports that the Sudanese government bombed the Dinka villages, while the army of Mujahedeen cleared the ground of its civilians. Aerial bombardment had become an everyday experience. Listening to the sound of the flying aircraft, the Dinka would easily differentiate reconnaissance planes from the fighter bombs or a relief transport aircraft. They prepared ditches around their safe havens in their jungles and swamps of the Nile to protect their families from air raids. Sudanese Human Rights concludes that on 15 May 2000, the Sudanese government authorised the aerial dropping of relief aid at the village of Akak; however, on 16 May the Sudanese Air Force bombarded Akak using an Antinov bomber. The Antinov dropped bombs killing unknown number of people. ${ }^{1013}$

In addition, aerial bombardments devastated the Dinka villages at the border areas between the North and the South. These badly depopulated areas included the vast counties of the Dinka around Abyei, Gok Machar and Aweil, where unknown number of children, adult women, men and cattle were killed and some taken for slavery in the North of Sudan. ${ }^{1014}$

\footnotetext{
${ }^{1010}$ African Rights, op. cit., p. 37.

${ }^{1011}$ Awatik Deng Majak, a Dinka Christian Animist, University of Juba states "I saw bad things during the war between the SPLA forces and the Mujahedeen of Omer al-Bashir. Inhabitants of our areas, Rum Aker, Achiro and Nyamlell were attacked indiscriminately. We lost many men, women and children, when Jihad was declared against the land. Houses were burnt after being looted".

${ }^{1012}$ Human Rights Watch (2000). World Report Entry, http://www.hrw.org/hrw/pubweb/webcat-93.htm

${ }^{1013}$ Sudan Human Rights (2000), op. cit., p. 11.

${ }^{1014}$ Jok, op. cit., pp. 6-10.
} 
The majority of the Muslim Arab students refrain from providing responses related to the issue of Jihad; however, one of the Muslim students provides an answer to the question that states "What is a practice in your religion regarded as sinful, indecent or immoral in which a violator is sentenced, what you think of it and how to deal with believers of other religions violating the same practice in Sudan? One student argues that: "There are no practices which I can really grade here as sins within our campus, beyond the Jihad of Al-Bashir and Turabi against the people of the South and Nuba Mountains. In my view, there is no Jihad that kills children, old women, old men and animals". 1015

Some moderate Muslims' politicians in dialogue with the Christian leaders agreed on the definition of the conflict in Sudan as political and economic violence and not a religious war. The ruling 'Muslim fundamentalists', however, insisted and characterised it as an Islamic one, where the inclusive Muslims are invited to participate in the war to launch Jihad against the opposition composed of Muslims, Christians and Animists fighting against the government of Sudan. During the conference of the religious dialogue between the Muslims and Christians that was held in Beirut, capital city of Lebanon, the Christian Pastors accused the 'Muslims fundamentalists' of having shifted the civil violence based on socio-economic dispute to a religious war between the inclusive Christians on one side fighting the Muslims in Sudan. Such a definition legitimated the Mujahedeen to launch extensive violence against the civil population in the South without discrimination of who were rebels and who were mere civilians. In its resolutions, the conference rejected the adoption of the religious tones in war and defined the violence of Sudan as economic. $^{1016}$

The primary concern today is that the application of Jihad and its method in South Sudan has created a new view among the Christians and the Muslims of the South concerning Islam as a religion that seeks to eradicate the people of South Sudan. For example, a Dinka Muslim student argues: "When Muslim Arabs entered into my homeland, Abyei in the South Sudan with the message 'God is the Most Great', we thought the call was a religious prayer of love, dedication for human salvation and people attended the prayers. After the declaration of Jihad against us, this call has changed in Abyei County. When a Muslim Dinka in Abyei heard the voice 'God is the Most

1015 Omer Abdul Majid, a Ja'alei, Omdurman Ahlia University.

${ }^{1016}$ Middle East (Spring 2003), op. cit., p. 2. 
Great', everyone knew that death had haunted them. The Dinka would know that the Mujahedeen have come with the voice of death and ran in astray to ... different directions for sanctuary". ${ }^{1017}$

This perspective of war in Sudan, under the slogan of Jihad has also created a new cultural anxiety and uncertainty between the Muslim Arabs at the North and the heterogeneous African Christians, Muslims and Animists residing in the South. According to Gudykunst, Anxiety is a feeling of discomfort that emerges, when people from different cultures meet each other in their institutions. Uncertainty is referred to the perceived unpredictability that results from this interaction. ${ }^{1018}$ In Escape from Slavery, the True Story of My Ten Years in Captivity and My Journey to Freedom, Bok and Tivan tell of the tragic uncertainty of Dinka ethnic group life in general after their interactions with the Muslim Arabs. Bok reiterates that his mother sent him to sell eggs and peanuts at a bustling market near his home village in the Southern Sudan. There Muslim Arab Jihadists burst into the market place. They were armed with rifles and long knives and saw them immediately busy with the murder of the Dinka men and women. When, people ask him, he explains: "I saw the dead Dinka men lying all over the marketplace. I saw more dead bodies than I could count-without heads, others looking as if they had just decided to lie down in the dust and go to sleep. I had never felt such terror confusion, and helplessness before or since in my life". 1019

Christian and Animist students testify that, after the declaration of Jihad, they had always experienced attacks, killings and displacements from their villages and moved to towns seeking protection from human rights agencies. Yet, in the towns they also frequently experienced discrimination, sometimes with lethal consequences. ${ }^{1020}$

\subsubsection{De facto discrimination}

As a term of social sciences, de facto discrimination refers to informal discrimination entrenched in social customs against a specific group. ${ }^{1021}$ Many Muslims students claim that the present government in Sudan advocates different procedures in dealing with the Internally Displaced Persons (IDPs) of Christians and Animists from the South, Muslims from Darfur and Nuba

\footnotetext{
${ }^{1017}$ Hassen Deng Kuol, University of Juba.

${ }^{1018}$ Gudykunst, William B (1995). Communication in Personal Relationships across Cultures, Thousands Oaks: CA Sage, p. 246.

${ }^{1019}$ Bok, Francis and Tivnan, Edward (2003). Escape from Slavery, the True Story of My Ten Years in Captivity and My Journey to Freedom, New York: St Martin's Press, p. 5-6.

${ }^{1020}$ Manuer Atak, University of Juba, Ater Mawien, Bahr el-Ghazal University.

${ }^{1021}$ Robertson (1981), op. cit., p. 295.
} 
Mountains in internal social structures of different cities, where they congregate to evade organised government assaults by militias on their villages. One student explains this situation as: "I see 'sinners' in the structure of power in Khartoum. The government forces attack the indigenous African Christians, Muslims and Animists in their areas in Ingessana Hills, Darfur, South Sudan and Nuba Mountains". ${ }^{1022}$ Another adds "And those who escaped from these ... organised and discriminatory assaults moved into exodus to some big cities, under the control of the government expecting the international humanitarian organisations to protect them. When some of them are rehabilitated by some humanitarian agencies as IDPs, the Arab Muslims in power stir their Arabs in social structures at these areas to submit petitions to the government accusing them of having practiced customs oppose to the Islamic teaching., 1023 A Muslim Fur notes that: "When the accusation is made, then the government acts by denying the IDPs equal access to water, schools and healthcare in their places. They expose them to become victims of abuse and humiliation by transferring them into a desolate desert and occasionally massacre them in those camps". ${ }^{1024}$ On the other hand, a Christian Animist student argues that: "Proportionally, prevention of services from the IDPs is a lesser issue and the greater one is the 'conspiracy' within the customary institutions of the Muslim Arabs. Every system under them applies 'conspiracy' that causes the death of a large number of people from the Christians and Animists of South Sudan. In Sudan, it is possible for the non-Muslim Arab people to die in a customary organised approach within the social institutions of our own country". 1025

The displacement of Christians and indigenous civilian Muslims from the South, Nuba Mountains and Darfur is primarily due to the widespread of violence, under Jihad. ${ }^{1026}$ Yet, the IDPs experience serious de facto discrimination also from successive governments. The former democratic government led by Sadiq Al-Mahdi and the present government both have created for them wretched and sordid conditions by subjecting them to massacre, abuse, humiliation and mockery against them within public institutions. First, Sanderson observes that the democratically elected government of Sadiq Al-Mahdi and dislodged by Al-Bashir in military coup in June 1989,

\footnotetext{
${ }^{1022}$ Imtisal Ahmed Mohammad, a Nuba Muslim, University of Juba.

${ }^{1023}$ Nafisa Adam Seisi, a Muslim Fur, University of Khartoum.

${ }^{1024}$ Ali Mohammad Ali, Muslim Fur, Omdurman Ahlia University.

${ }^{1025}$ Alier Bol, a Dinka Christian Animist, University of Juba: "Every system in Sudan is corrupted by the Muslim Arabs political attitudes to citizens. Under democracy, you find them making a conspiracy. Instead of enjoying their schools, hospitals and clean water, they kill us".

${ }^{1026}$ Iyob and Khadiagala, op. cit., p. 134.
} 
disregarded the values of humanity by adopting discrimination within national institutions against the Dinka ethnic Christians and Animists of the South. The regime recruited and armed the militia of Arabs; known as muraheleen masquerading to fight the insurgents the SPLA. In practice, the muraheleen attacked the Dinka civilians at their villages accusing them of being supporters of the insurgents. Such practice has caused the displacement of men, women and children of the Dinka who moved to the city of Dhein, Southern Darfur. Thousands of the Dinka and women were 'massacred' in March 1987, apparently in an operation planned and organised by the government organisations. ${ }^{1027}$ Second, in 1994, the UN report accused the Government of Sudan, under President Al-Bashir of pursuing an undocumented pattern of discrimination in the public institutions of the state against the Christians and Animists from the South. Their movements were restricted, places of worship bulldozed, and they were even deprived food. According to the report, such methods evicted the IDPs from their camps and forced them to the desert. ${ }^{1028}$ Francis Deng witnessed their conditions and described that they were most appalling. The IDPs resided in squatter urban areas, where they endured hardships as the government deprived them of shelter and food leave alone access to education, health and political rights. ${ }^{1029}$

Little has changed after this, the UN Humanitarian Coordinator; Ameerah Haq reported that the government forces attacked the IDPs in the Kalma camp, at the suburb of Nyala capital city of the Southern Darfur State on 25 August 2008, accusing them of misconduct. Sixty heavily armed military vehicles entered the camp that hosts more than 80,000 IDPs. Terrified IDPs reacted and armed themselves with sticks, knives and machetes, but the government forces set about shooting at them and their straw huts putting them a blaze. Such actions severely threaten the safety and security of civilians who have a right to protection, under International Humanitarian Law. Haq concluded that the UN urge for restraint and call for the immediate establishment of a humanitarian corridor, so that the injured might be evacuated. ${ }^{1030}$ Such acts of de facto discrimination produce new identities based on racial definitions among the people as it can be seen from the students of the South. The majority of them claim that they have experienced unjustified discrimination from

\footnotetext{
${ }^{1027}$ Anderson, G Norman (1993). Sudan in Crisis, the Failure of Democracy, Gainesville: University Press of Florida, pp. 28-29.

${ }^{1028}$ UN Special Rapporteur Report (1994). "Implementation of the Declaration on the Implementation of All Forms of Intolerance and Discrimination Based on Religion and Belief”, Commission on Human Rights, Dis. General E/CN.4/ 1994, p. 24.

${ }^{1029}$ Deng, Francis Mading (1994). "Stop the carnage", Brooking Review, Vol. 12 No. 1, p. 8.

${ }^{1030}$ United Nations (2008 August, 26). "Statement of the United Nations Humanitarian Coordinator, Ameerah Haq on Kalma Camp", http://www.un.org/News/ossg/hilities/hilities_arch_view.asp?HighID=1145.
} 
the Northern Muslim Arabs in control of power and wealth and that such treatment has built a history of politically shared experiences of hardship and discrimination among them transforming them into a unified new political identity of the "the marginalised majority". ${ }^{1031}$ According to Idris, political marginalisation and discrimination against the peripheral African groups by the successive governments have caused the heterogeneous populations from the South to unite and claim nationalism. Idris believes that in due course, their nationalism will lead to the achievement of an independent nation-state from the Muslim Arabs of North Sudan, where they can revive their cultural values banned by the Northern Sudan institutions. ${ }^{1032}$

\subsubsection{Ideological Islam versus an Ordinary Islam}

One question in the questionnaire used in this research asks: "How many festivals do you celebrate in your religion; where and how do you offer sacrifice and do you face restriction or limitation of worship in anywhere in Sudan?" This question elicited controversial responses from the students. Some Muslim students claim that: "Islam has given clear method of worship to God as they are found in Holy Quran and Sunna. Diversity in religion is a wrong path; a Muslim must acknowledge only God and His Messenger and nothing more or less than this holy recognition". ${ }^{1033}$ Another student offers a serious rejection to religious diversity and states: "It is necessary for our Muslim politicians in the country to address religious diversity seriously and remove away pagans' practices among us". ${ }^{1034}$ A third one claims that: "It is worthy for a Muslim to please God and not to promote pagan beliefs disguised as diversity in cultures". ${ }^{1035}$ One Muslim concludes: "There is a need to close off diversity in religions and cultures in our Islamic territory of Sudan". 1036

The conclusions of these Muslim students about the religious diversity in Sudan have not offered alternative solution to the state on how to address the existing and dominant reality of religious and

\footnotetext{
${ }^{1031}$ Amal Nur Al-Din Mohammad, a Muslim Nuba, Omdurman Ahlia University: "We have a shared problem that is unjustified mistreatment and discrimination of us by Arabs, because we are African Muslims, Christians and Animists from Darfur, Nuba Mountains and Ingessana. Our shared hardships of lives and discriminations form all the Arab Muslims systems in Sudan made us to be one with those in the South, Nuba Mountains and Ingessana. We consider it as our nationalism of the marginalised majority."

${ }^{1032}$ Idris, op. cit., p. 24.

1033 Al-Nahar Ali Mohammad, Juhayinna Arab of El-Gezira, University of Khartoum from.

1034 Jadwa Mohammad, a Muslim, a Ja’alei Muslim University of Khartoum.

${ }^{1035}$ Majid Abdullah Ahmed, a Shaiqqiyyia, Omdurman Ahlia University.

${ }^{1036}$ Hamza Ali Hassen, a Muslim, University of Khartoum.
} 
cultural diversity. ${ }^{1037}$ Instead, it appears that they support a policy of eradicating diversity and substituting a homogenised Muslim population. On the other hand, the majority from the Muslim students supports the presence of Animism and Christianity as legitimate religions in Sudan and rejects the concept of eradicating them. This appears in the questionnaire question: "How conversion from one religion to another religion in Sudan is conducted; do you encounter an obstruction on the process and have you ever felt that there has been an interference of your ethnic customs, cultures and traditions to your religion, if yes, please explain?" These students present their arguments claiming that: "Muslims of Sudan never knew Islam. Some became Muslims in a popular way or on the virtue of their parents, who might have been influenced by Islam mixed with politics and Arab culture. Such believers transform Islam into political ideology and at that phase, the religion deviates from its authentic category of faith, where we take it as a private issue into ideological religion". ${ }^{1038}$ Another one states: "If the Islamic government in power wants peace in Sudan, it must accommodate religious and ethnic diversity in the state, including free worship of the Christians and the Animists". ${ }^{1039}$ One student noted: "In Holy Quran, God dictates respect to diversity as states 'O mankind, surely We have created you from a male and a female, and made you nations and tribes that you know each other". ${ }^{1040}$ Finally, an open-minded student says: "In our university, I have some friends from Christians and Animists, yet, I worship God in the way He dictates to respect diversity and Nassari (Christian) worships his God and we live together in Sudan". 1041

The moderate Muslim students provide an alternative resolution that could be interpreted as religious tolerance towards people of different religious cultures to live together and exercise their different methods of worship. Constitutionally, there are two sources of law in Sudan, the Sharia for the Muslims and customs for the Christians and the Animists. For instance, Article (6) of the Interim Constitution of 2005, states: "The state shall respect the religious rights to: (a) worship or assemble in connection with any religion or belief and establish and maintains places for these purposes". 1042

\footnotetext{
${ }^{1037}$ Simone, op. cit., the socio-political structure of Sudan qualifies it at international media as an intersection of religious, ethnic and culture diversity. This form of the structure stimulates "Western academics" to consider Sudan as a state that cannot to maintain functional political coherency, p. 24.

${ }^{1038}$ Eisa Adam, Hawazama, University of Juba.

1039 Aziza Ali Babker, a Nuba, University of Khartoum.

${ }^{1040}$ Al-Taib Muhammed, a Zagahwa, University of Khartoum.

${ }^{1041}$ Sada A. Shaiqqiyyia, Omdurman Ahlia University.

${ }^{1042}$ Constitution (2005). Interim Constitution of the Republic of Sudan Entered into Force, 6 July 2005.
} 


\subsubsection{Suppression of libation}

The questionnaire included a question that states: "How many festivals do you celebrate in your religion; where and how do you offer sacrifice and do you face restriction or limitation of worship in anywhere in Sudan?" A Dinka Christian Animist explains how religious ritual libation is conducted among the Dinka and Nuer. He describes: "Libation is one of the oldest religious customary ritual performances among us. It is a duty of the Dinka women to produce a sort of drink called mou (alcohol) manufactured from milled sorghum flour blended with water and cooked to the stage of becoming ... semi soft and solid. This substance is mixed with water and traditional yeast made of sorghum and left to spend sufficient time to transform itself into alcohol. At this phase, it is sifted and its water is entirely transformed into a chemical liquid known traditionally mou. This liquid substance aggregates the Dinka people to come together and share it as food and libation to the souls of the other world. Those who drink take it as food and libation, while those who do not drink participate in it as a libation. Mou with its meaning of libation is not allowed ... in Khartoum constitutionally. Women who produce this kind of associated religious drink are detained and punished in the jurisdiction of the Northern Sudan". ${ }^{1043}$

The sharing of mou transforms it into the status of religious rite, because, it revives the moments of communion relationship between the departed souls to the next world and the individual relatives that might be drinking or not drinking, but attending, listening and watching the drinking ceremony. It reminds them of the continuity of relationships between the past souls and the present people on the earth as perceived community. The Islamic North, however, interprets the rite as illegal consumption of liquor and detains its producers, the women. Amnesty International reports that one of the houses of a Christian family at the suburb town, Haj Yusuf in Khartoum, where majority of the IDPs from the South reside was assaulted by the government police force, because the Dinka family in that house was alleged to have produced alcohol and drunk it. Amnesty concludes that the attack contradicts the legal penal code of Sudan, where article 78 (2) articulates that the act of the non-Muslim drinking as opposed to the dealing in alcohol is punishable, if it is in public places or it causes annoyance to others. ${ }^{1044}$

The detention of Christians and Animists, because of alcohol may depend on the interpretation of the customary laws, but the constitution of Sudan that was in effect when Amnesty reported the

\footnotetext{
1043 Kon Deng, University of Bahr el-Ghazal.

${ }^{1044}$ Amnesty International (2003, July). "Empty Promises, Human Rights Violations in Government Controlled Areas, Amnesty International, AI Index: AFR54/036/2003.
} 
incident of this detention permits the laws related to religious customs. Article 139 (a) of the Constitution of 1998 states: "Sharia, then consensus of the people expressed through referendum, the constitution and customs are the sources of law". This is very plain, unless there is an interference of parallel interpretations; otherwise, the constitution allows the customs as the sources of laws for non-Muslims, but the reality is different. Often, when a group of Animists conducts religious rituals of libation, the security of the state considers the act as a consumption of alcohol; however, alcohol is not prevented constitutionally to the non-Muslims. Article (16) of the same constitution enumerates that the state will seek by laws and directive policies to purge society from ... the consumption of alcohol by Muslims. ${ }^{1045}$

At this stage, the exclusion of the Christians and the Animists from the Islamic laws which illegalise consumption of alcoholic beverages is defined and legalised. The consumption of mou as a customary liquor associated to the religious rites of the Dinka and Nuer in locations, where Muslims also live conforms to the first religious tolerance between the Muslims and the Christians. Its rejection is totally irrelevant to the prophet Muhammad tolerance towards the religious worship of other faiths. According to Aziz, Prophet Muhammad has taught tolerance to Muslims towards other religions before, one year of his death, he illustrated a concrete example of freedom in religions, when a large delegation of Christians from Najran, near Yemen visited him, under the guidance of their religious clerics. The reason for their visit was to discuss the existing differences between two faithful doctrines of Islam and Christianity. The host accommodated the visiting Christians in the rooms which were attached to the mosque. Later, the faithful Christians enquired from the host, the prophet a place to assemble for Christian religious offerings and rites. In turn, the prophet directed them to perform their rituals in the mosque adjacent to their rooms. ${ }^{1046}$

The example of the Prophet to his host marks Islam as a private faith that tolerates religious rituals of a diverse religious society. According to de Waal, it is of great significance to distinguish 'popular Islam' and ideological Islam. The two are antithesis as the former appreciates a phenomenon of peaceful diversity, where Islam is regarded as a private faith and the latter takes Islamism as an inclusive ideological faith. This ideological Islam has been in political domination in Sudan and its adherents control power and sponsor their organisations and agencies in social structures in order to build an assumed utopian Muslim society based on the Sharia. de Waal

${ }^{1045}$ Constitution (1998), op. cit., p. 156.

1046 Aziz, p. 15. 
concludes that the consequences of the implementation of this aim in national institutions are suppression of cultural pluralism in the country. ${ }^{1047}$

\subsubsection{What is wrong with Islam?}

For some students, suppression of cultural diversity in the name of a religion is described as a 'wrong' practice that leads the Muslim away from the right teaching of Islam that considers tolerance towards other religions, since Islam states: "There is no compulsion in religion". ${ }^{1048}$ According to Ansari, the development of what looks like homogenous Islamic fundamentalism operating effectively today globally for the revival of a monolithic Islam has reinforced popular perception in the Western World of what appears to be "wrong with Islam". ${ }^{1049}$ Nevertheless, this writer argues that something is 'wrong' with people and not Islam as a religion. In Sudan, the author has witnessed that Muslims, Christians and Animists are not allowed to sell food during Ramadan, a fasting month of Muslims. In answer to the questionnaire question that asks: "Is religion important and what is your concept about the world in accordance to your religion, does it allow space for other religion(s), if so, please explain?" The majority of Christian, Animist and Muslim students argue that religion is a private business of individuals and allege the Government of Sudan of having constituted laws that fight religious diversity. The students believe as there is a need for political forces to constitute a constitution that promotes religious diversity in Northern Sudan ${ }^{1050}$ rather than formulating an Islamic law in a way that fits Muslim Arab culture at the expense of the African Muslims, Christians and African traditionalist cultures. ${ }^{1051}$ Religion is a private belief of individuals; however, it does not function in that way in the Northern Sudan. During Ramadan, the government police detain people that sell food for non-Muslims in Northern Sudan, including Khartoum, our capital city of all citizens that include Christians, Muslims and Animists. One student concludes that these Islamic laws are not changed, until today, but operational. $^{1052}$

\footnotetext{
1047 de Waal (2004), op. cit., pp. 4, 12.

1048 Osman Atia, a Beja, University of Khartoum, Mahamoon Ali, a Mahas, University of Khartoum.

1049 Ansari, Sara (1992). Sufi Saints and State Power: The Pirs of Sinds, Cambridge: Cambridge University Press, p. 372.

${ }^{1050}$ A M, a Muslim Nuba, University of Juba.

${ }^{1051}$ Makur Dongrin, a Dinka Christian Animist at University of Juba.

${ }^{1052}$ Malual Makur, a Dinka Christian Animist, University of Juba argues "In Cairo, religion is a private business and in Sudan it is a state business. In Khartoum, capital city of all faiths police arrest people being found selling food during the Muslim fasting time of Ramadan, but in Cairo, you can eat anywhere".
} 
Constitutional Court Act of Sudan Chapter six (6) Article (24) states: "Owners of restaurants and cafeterias and everyone selling food or drink must not sell during the day during Ramadan". ${ }^{053}$ Those who violate this constitutional provision are detained and punished before criminal courts. Amnesty International reports that the application of the Sharia in Sudan places the women at a disadvantage. In the towns of Northern Sudan, women hold responsibilities in the majority of households. Men might be in the national service of army, dead or to be absent searching for agricultural work far away from the cities. This situation obliges women to organise some cooperatives to sell peanuts, tea and food, but the policemen arrest them and charge them and they can be sentenced to heavy financial fines or imprisonment. ${ }^{1054}$

Some Muslim students from the North claim that laws are made in Sudan to promote religious intolerance: "Muslim Parliamentary Members in Sudan reject the enactment of one constitutional law that promotes diversity". 1055 "Laws are only enacted to serve the interest of religious intolerance. It is intolerance which brought the existing hatred between the Muslim Arabs versus the African Muslims, Christians and Animists in Sudan". ${ }^{1056}$ Another one states: "It is this religious mis-representation that caused the last war between the Christians and the Animists of the South against the Muslims in power. This kind of legal initiative has developed and created political and social hatred between the Muslim Arabs at one hand against the Christians Animists from the South". ${ }^{1057}$ A liberal-minded student concludes: "I always tell my Muslim colleagues that it is wise for us, Muslims, Christians and Animists to introduce a new chapter of religious relationship, on the basis of tolerance, because that approach will help each one of us to understand the traditions of the opposites". ${ }^{1058}$ According to Ingpen and Wilkinson, to know the cultures, traditions and customs of our neighbours or to cross borders into other states helps us to be more tolerant. The UN defines tolerance as a total recognition and appreciation of others as they are. It requires an active ability to listen and appreciate others. All in all, it is a sound foundation for political, civil and social institutions. Tolerance is the centre of building universal world peace. ${ }^{1059}$

\footnotetext{
${ }^{1053}$ Constitutional Court Act of Sudan 1998 and Revised in 2005.

${ }_{1054}$ Amnesty International (2003, July), op. cit., p. 1.

${ }_{1055}$ Adel Abdel Rahaman, a Muslim Hawawir, University of Juba.

${ }^{1056}$ Sadia Hashim, a Muslim Beja, Omdurman Ahlia University.

${ }^{1057}$ Hamed Ibrahim Mohammad, a Muslim Shaiqqiyyia, University of Khartoum.

${ }^{1058}$ Muna Yasar, a Muslim Mahas, University of Khartoum.

${ }^{1059}$ Ingpen, Robert and Wilkinson, Philip (1994). A Celebration of Customs and Rituals of the World, Surrey: Dragon's World Ltd, p. 7.
} 
Prevalence of religious 'hatred' in social structures of Sudan is easily shifted to the level of igniting violence, a violence that causes human tragedy and dire situation for food and safety. ${ }^{1060}$ In this regard, the existence of conflicts emerging from religious intolerance, power and wealth sharing in Sudan dictates political leaders to introduce political alternatives in addressing them.

\subsection{Search for conflict resolutions}

The absence of an acceptable constitutional system for the citizens of Sudan breeds violence. Therefore the question "What system suits Sudan best and how do you want national identity........ to be defined in a national constitution of Sudan and why you think so?" is an essential one in the research questionnaire. The answers reflect the students' different opinions, in regard to the construction of national identity in Sudan constitutionally. Their opinions could contribute in building a unified constitution, where every citizen and every culture is represented. One of the students argues that: "Sharia is a law from heaven. It organises our social and political life as Muslims and would be difficult for the SPLM to establish the New Sudan that rejects this law in Khartoum, unless it applies that in the territory of the South". 1061

Some relevant views to the promotion of the Sharia come from the answers to the questionnaire question that states: "What are practices in your religion regarded as indecent or immoral, in which a violator must be sentenced and do you think such practices are manifested at your university campus and any other place in Sudan?" Some students who have answered this question argue that: "Currently, after the CPA of 2005, 'the New Sudan' is on the process in the South. Women in the South dress in immodest mini-skirts. So, the North and the South are two totally different worlds in terms of culture, because, our women in the North dress in modest clothes in order to show their Islamic identity as good Muslims". ${ }^{1062}$ Another student remarks: "We have a solution to the conflict of cultural identity in Sudan. 'New Sudan' is an evil system and thus, those who want it, let them go to the South and make their own country of secularism, where a Muslim rejects injunctions of the Quran. I hate to watch women of the, so called New Sudan walking around here at our campus without scarves at their heads, including Khartoum, the city of Islam" ${ }^{1063}$ Finally, another echoes these sentiments and states: "For us Muslims, scarf is a traditional dress received from the modest

\footnotetext{
${ }^{1060}$ Meyer, op. cit., p. 99. The situation of refugees in the UN camp at Lokichokio between South Sudan and northern Kenya is inhabited by the most skeleton refugees' children because of hunger.

1061 Ahmed Nur al-Daeim, University of Khartoum.

1062 Hassan Hamadi Khader, Omdurman Ahlia University.

1063 Anor Saeed, University of Khartoum.
} 
women of the Prophet Muhammed. So any pious Muslim woman takes it on her head to show a respect to Muslims. It is important for a Muslim woman to conceal her body, which the secularists of the 'New Sudan' dislike. Let them go ... and build their independent state". ${ }^{1064}$

In contrast, other Muslims who answered the questionnaire question: What are the duties of the faithful in your religion and the roles of women argue: "Let me be very clear, we in the 'New Sudan', if the National Congress Party does not want a secular state, then we in Nuba Mountains would join the South. I love freedom that does not discriminate. Sharia discriminates against nonMuslims and women, so why do we live here ${ }^{1065 \text { " }}$ One Muslim concludes that: "Anyone in Sudan who needs a permanent constitution for all people, whether Muslim Arabs, Muslim Africans, Christian and Animist Africans must apply the model of John Garang of the 'New Sudan'. This political ideology of Garang creates for the people of Sudan a better constitutional system that is based on democratic pluralism, where Christianity, Islam and Animism are set apart from the state's national constitution."1066

The system that Garang advocated is based on the dialectical concept of the 'New Sudan' vision. It is structured in phases, which he called 'Modalities for the Solution' of the conflict of identity in Sudan. Garang considered these modalities as conflict resolutions for war between the SPLM and the Government of Sudan. ${ }^{1067}$ The first of these modalities is the structure of the state, Sudan, under the name 'New Sudan'. Garang defined New Sudan as a democratic transformed Sudan attractive to all citizens. The basis of this attractiveness is the separation of the state from religion. According to him, a constitutional system, where laws are derived from any religion eradicates freedom, equality, liberty and respect of fundamental human rights of citizens. For him, taking religion into a constitutional system removes the operation of these fundamental values which are the basis for a democratic society. ${ }^{1068}$

Furthermore, addressing the audience on 20 March 2002, at the Carter Center, Atlanta, Georgia in the United States, Garang said that the long negotiations of the SPLM and the present government disprove the feasibility of the 'New Sudan' model. Therefore, the SPLM negotiated to achieve

\footnotetext{
${ }^{1064}$ Idris Mohammad, University of Khartoum.

${ }^{1065}$ Kamal Omer, Nuba, University of Juba

${ }^{1066}$ Nhial Kur Akol, A Dinka Christian Animist, University of Bahr el-Ghazal.

${ }^{1067}$ Iyob and Khadiagala, op.cit., During the period of 2000-2005, the seasonal veteran of many wars and failed peace agreements had held out the hope that with the debunking of the old racial geographic divides that had been inherited from the Old Sudan they would be wiped away by the introduction of the New Sudan of equality in the signed Comprehensive Peace Agreement in 2005 between the Government and SPLM, p. 169.

${ }^{1068}$ Position Paper of the SPLM in Peace Negotiation in Nairobi, Kenya 1994, p. 4
} 
model two, the 'Sudanese Commonality' based on a confederate system. The SPLM resorted to this model, because the Islamic North insisted that the Sharia must not be separated from politics, but accepted the exemption of the South. However, the experiences of the exemption of the South from the Sharia in legal procedures have proven to be flawed. The Christians and Animists still remain victims of the Sharia to the extent of Christian women being stoned. It is under this extreme disagreement over religious identity which made the SPLM to another shift, in order to negotiate over the building of two states: a Northern state, under the Sharia and another state of South Sudan, under secularism. Citizens should be allowed to vote, during a transitional period between two models, either the first model of 'New Sudan' or the model of confederation, but not the current model of an "Islamic Arabic Sudan"1069 and not even the model based on the indigenous "African Secular Sudan', because, it also lacks political consensus. Therefore, the only viable alternative resolution is the model of two separate states. This happens, after the end of the agreed tenure of a transitional period, where the people of the South would vote for self-determination between unity and separation of the two territories. ${ }^{1070}$

Responses of some students, Muslims, Christians and Animists in Sudan to the questionnaire strongly demonstrate that war in Sudan has been fought between the adherents of ethnic territorial national pluralism in opposition to the adherents of ethnic territorial nationalism. The former call for the adoption of a diverse constitutional system that reflects inclusive cultures in the territory and the latter calls for the adoption of the specific identity based on Islamic and Arab culture. These two schools have widened their lines of disagreement and that threatens the territorial integrity of Sudan. The Christian Animist students argue that "In Sudan, we the indigenous African Animists, Muslims and Christians in the Southern territory, Nuba Mountains, Ingessana and Darfur have been the subjects of abuse and oppression in our home. Today, we have ... united, under the slogan of 'New Sudan' which is free from religious and Arabic slogans that divide us". ${ }^{1071}$ On the other hand, some Muslim students at the University of Khartoum and other universities with ethnic Arab

\footnotetext{
${ }^{1069}$ Garang, John (2002, March). "Modalities for Peace in Sudan”. A political paper presented by Garang to the audience at Carter Center in Atlanta USA on 20 March 2002.

${ }^{1070}$ Ibid.

${ }^{1071}$ Mathinag Kon, a Dinka Christian Animist, University of Bahr el-Ghazal; Najwa Abdella, a Nuba Muslim, University of Khartoum; Sarah Abdu Mahmoud, a Fur Muslim, University of Khartoum;
} 
background maintain that the concept of 'New Sudan' is a complete attempt to remove their Islamic religion and Arabic identity from Sudan. ${ }^{1072}$

These contradictory statements, even though they come as individual opinions give an impression of the existing political relationships between the Christians and Animists of the South in unity with the indigenous Muslims of Darfur, Nuba Mountains and Ingessana. The people of the South feel wrath towards the Muslim Arabs in power. The presence of such wrath will probably lead to the separation of the two religious identities in a referendum of self-determination in early January 2011 or such a situation will change and the Christians and Animists in the South vote for the maintenance of unity. According to Collins, no amount of rhetoric can overcome the fact that today overwhelming numbers of Southern Sudanese are open to speak out as separatists. This is no surprise after the slavery, discrimination and racism that they have severely endured at the hands of the Northern Muslim Arabs in power. Since independence, too many promises have been broken and millions have been killed or driven from their homes. The people of the South are still often despised. Collins concludes that it is time the two million unwanted Southern Sudanese Christians and Animists milling around Khartoum leave and go to their independent home, South Sudan after the referendum of 2011 and under international supervision. ${ }^{1073}$

Self-determination for the people of the South was not initially an easy political decision, during the successive peace negotiations. Political negotiations were shifted under the auspices of a regional organisation, known as Inter-Governmental Authority for Drought and Development (IGADD), after the collapse of political talks between the warring parties in Abuja I and II from 26 April to 18 May 1993. The IGADD is a regional organisation composed of the Eastern African countries of Kenya, Eritrea, Uganda, Djibouti, Ethiopia and Sudan. ${ }^{1074}$ On 7 September 1993, the IGADD established a 'Peace Committee' and charged it as a mediating body between the SPLM and the Government of Sudan. During political negotiations between these two parties, the head of the government delegation, Ghazi Saleh el-Din el-Atabani, announced at a press conference held in Nairobi, Kenya that the issue of self-determination had no legal or political basis and the state of Sudan would continue to be ruled by the Sharia. On the other hand, the SPLM at its press

\footnotetext{
${ }^{1072}$ Faisal Ali, a Shaiqqiyyia Muslim, University of Khartoum; Alawia Khalid, a Muslim Ja'alei ,University of Khartoum; Muhammad el-Khatim Abdullah, a Shoukuri, University of Khartoum; Khalid Ahmed, a Kababish, University of Juba; Zenib Ali Muhammed, a Muslim Shaiqqiyyia, Omdurman Ahlia University; Sumia Ali Al-Nur, a Muslim Reizegat, University of Khartoum.

${ }^{1073}$ Collins (2005), op. cit., p. 1.

${ }^{1074}$ Lesch, op. cit., pp. 174, 179.
} 
conference reiterated the importance of separating state and religion and the right of selfdetermination to the people of South Sudan to choose between unity with and separation from the North, under the international supervision of the United Nations. ${ }^{1075}$

Those two press conferences demonstrated the crucial political differences over the issue of selfdetermination and separation of religion from the state. In the view of one student: "No one can ... negotiate with Muslim fundamentalists; it is either you defeat them at the frontline of war or they annihilate you. Defeating them on the battlefields of war is a medicine that forces them to the table in peaceful negotiation. If you are weak militarily, then you are finished" ${ }^{1076}$ A lack of progress at different forums of peace negotiations between July 18-30 and 6-7 September 1994 was caused by the rejection of the Government of Sudan to concede pluralism of cultures and its insistence that the Sharia would not be rescinded. Ghazi Saleh el-Din el-Atabani, the head of the government delegation and a State Minister at the Presidential Office presumed at another press conference in Nairobi that an Islamic Empire would have eventually been established in Africa, if it had not been hindered by European colonialism. As colonialism had now been defeated the Government of Sudan wished to continue the injunction of Islam not in South Sudan alone, but beyond. ${ }^{1077} \mathrm{He}$ also declared that the intention of the government delegation in Nairobi was not to negotiate on Sharia and self-determination. These two entities could not be negotiated on a political table. ${ }^{1078}$

This statement from the head of a peace delegation shows that political settlement was by then stagnant, since negotiations over two central issues, separation of state from religion and selfdetermination could not be approached. The matter could only be settled by the use of force. A Nuba Muslim student from Nuba Mountains states: "The Islamists reject a pluralistic constitution in order to get away with Sudan as an Arab Islamic state, but we are not Arabs and our former leader Dr John Garang taught them some ... lessons on the battlefield and that forced them to the table to negotiated in good faith. It was under the bullet of a gun from Garang which fractured them and accepted the provision of self -determination to the people of the South and 'popular consultation' to the Nuba which is also self-determination". 1079

\footnotetext{
1075 Mayo, David N (1994). "IGAAD Meditation Role in the Sudanese Conflict Reaches a Dead End Will the UN Security Council Take over from Them? The Sudan Newsletter, University of Pennsylvania, African Studies Center, Vol. 4, No. 3, pp. 1-2.

${ }^{1076}$ Ayuel Kon Bol, a Dinka Christian Animist, University of Juba.

${ }^{1077}$ Mayo, op. cit., pp.1- 2.

1078 Ibid.

1079 Ali Mahmoud, a Muslim, University of Juba.
} 
There was nothing left for the peace negotiations of the IGAAD Ministerial Committee after the refusal of the government to negotiate over the Sharia and a provision of self determination to the Christians and Animists of the South as the SPLM was not prepared to give up these conditions. John Garang described the fall of the peace negotiations as a "Zero Interim Period". ${ }^{1080}$ A Dinka Christian Animist student argues that: “Omer Al-Bashir as a Muslim Arab imposes constitutional Sharia on us and when we say no, then he puts a good number of guns at our chests, and when we looked around for the reaction of our friends and brothers in faith, there was no one, except the United States of America, Norway, Great Britain and Italy. These are our brothers; they have ... fulfilled the Jieng wise proverb that says: 'God makes me sick in order to know my brother'. These countries supported the people of the South by the time we were faced by the threat of forced Islamisation and Arabisation in Sudan."1081

Public opinion among the students from the South, Nuba Mountains and Darfur tends to praise the United States and its government. Amina Adam Ahmed from Darfur states: “The USA provides us humanitarian shelter; without the USA, we would have ... perished under Al-Basher's guns". ${ }^{1082}$ It is $t$ be noted that the humanitarian involvement of the USA in support of the people of Southern Sudan has established a sense of 'brotherhood' among many Christians and Animist in the South. It dates back to 1989, when US Congressman Mickey Leland from Texas visited the Southern Sudanese refugees in western Ethiopia. The visit ended up in a tragic accident, when his plane crashed killing him along with fifteen others. ${ }^{1083}$ Second, during the peace talks the Government of the United States instructed its Ambassador to Nairobi, Melissa Wells to follow them closely at the forum of IGAAD. ${ }^{1084}$

Despite the praise from some students, among the majority of Muslim Arab students, the United States is not favoured. A student at University of Khartoum argues: "John Garang had wanted a constitutional system that makes us become secularists in order to surrender us to the USA. During the war ... the National Democratic Alliance, NDA betrayed the message of our religion. The Muslim political parties within NDA cooperated with the enemy of the people, the USA and John Garang with his dangerous philosophy of 'New Sudan' and they accepted the provision of self-

\footnotetext{
${ }^{1080}$ Sumbeiywo, op. cit., p. 36.

${ }^{1081}$ Deng Dac Atem, a Christian Animist, University of Juba.

${ }^{1082}$ Amina Adam Ahmed, a Muslim Fur, University of Khartoum.

${ }^{1083}$ Mayo (1994), op. cit., p. 1.

${ }^{1084}$ Ibid.
} 
determination to the South. To me, that unity was treason; the USA with its International Zionist Movement will consider the South as a base to destroy the Islamic propaganda in Africa."1085

The National Democratic Alliance (NDA) composed of fifteen political associations which forged an alliance, after the military government under Al-Bashir seized power in 1989. The NDA allied with the SPLM and accepted the separation of state from religion. In June 1995, the NDA announced in Asmara, the capital of Eritrea, a document called 'Declaration of Principles' (DOP), according to which, unity with the South must be made through allowing the people of the South to exercise the right to self-determination. ${ }^{1086}$ In October 2002 George W Bush, the President of the United States, signed the document called 'Sudanese Peace Act', which pressed the warring parties, the Government of Sudan and the SPLM to adhere to the principle of peaceful negotiations. ${ }^{1087}$ In 2002, the Government of Sudan finally accepted the provision of self- determination to the Christians and Animists of South Sudan, during peace negotiations at the town of Machakos, Kenya held from 18 June to 20 July 2002. The document of the agreement came to be known as the Machakos Protocol. ${ }^{1088}$

\subsubsection{Self-determination and popular consultations}

Generally, self-determination emerges as a political objective for a minority that feels that they have been exposed to injustice by the governing group of a sovereign state. In international politics, this term gained credence after the First World War, when the victorious great powers asserted that ethnic nationals that lived in multiethnic Ottoman, Austro-Hungarian, and Russian Empires should be allowed to determine their political destiny. In practical terms, the right to self-determination was nevertheless denied to the defeated nations, such as Germans living in territories annexed by the winners, and especially to all non-European peoples living in the colonies. ${ }^{1089}$

Peace negotiations between the Government of Sudan and the SPLM led to the ratification of peace on 9 January 2005 in Nairobi, under a document called 'Comprehensive Peace Agreement',

\footnotetext{
${ }^{1085}$ Mohammed Munem, Shaiqqiyyia at University of Khartoum.

${ }^{1086}$ Sumbeiywo op.cit p. National Democratic Alliance include by then, Umma Party, Democratic Unionist Party, Sudan People's Liberation Movement, General Council of the Trade Unions and Federations, Legitimate Command of the Sudanese Armed Forces, Beja Congress, Sudan Alliance Forces, Federal Democratic Alliance, Free Lions Association, The Arab Baath Socialist Party, Independent National Figures, Representatives of the Liberated Areas, Union of the Sudan African parties, USAP, Sudanese National Party 36.

${ }^{1087}$ Sudan Peace (2002, October). Sudan Peace Act, p. 1-3.

1088 Comprehensive Peace Agreement (2005, January 9). Naivasha Nairobi, Kenya.

1089 An’Naim (1999), op. cit., pp. 199-223.
} 
CPA. ${ }^{1090}$ Its terms include article 2.5, which allows the right of self-determination for the people of South Sudan to be exercised in an internationally supervised referendum organised jointly by the Government of Sudan and the SPLM/A after six years of transitional period. The people of the South are to vote either to maintain the present form of a unified Sudanese state or to separate the South from the North to form a new independent state. ${ }^{1091}$ Article 3 of the CPA grants to the Nuba Mountains and Ingessana (Southern Blue Nile) less right called 'Popular Consultations' rather than self-determination. Paragraph 3.3 of this article stipulates that the legislature of the two States shall each establish a Parliamentary Assessment of Evaluation Commission to assess and evaluate the implementation of the agreement in each State. The two Commissions shall submit their reports to the legislature of the two States by the fourth year of the signing of the CPA. ${ }^{1092}$

The issues at stake in the vote are vast, but certain main provisions can be highlighted. Chapter three of the CPA deals with the 'Sharing of Wealth'. Article three paragraphs 5.6 articulates that, after payments to the Oil Revenue Stabilisation Account and to the oil producing states and regions, fifty per cent of the remaining net revenue derived from the oil producing wells in Southern Sudan shall be allocated to the Government of Southern Sudan (GOSS) at the beginning of the Pre-Interim Period. The remaining fifty per cent goes to the National Government and to the other States at the centre, west, east and far north which are called the Northern territory of Sudan. ${ }^{1093}$

There are factors in the views of the Animist and Christian students from the South which may prompt the indigenous groups in South Sudan to opt for the secession, rather than, unity, yet there is no certainty, since students' views do not necessarily represent the native people of the South. The answers of the Christian Animists to the question, What system suits Sudan best and how do you want national identity to be defined in a national constitution of Sudan and why you think so imply that these students would not desire the co-existence with the North, because of the $50 \%$ of oil revenues which the North currently takes from them and goes without a corresponding economic contribution to the South. Students argue that the South has no economic advantage to maintain its current social and political links to the North. Atong Riak Akon Riak, a Dinka Christian Animist student at the University of Khartoum states: "The unity of Sudan should not be maintained at the

\footnotetext{
${ }^{1090}$ Comprehensive Peace Agreement between the Government of the Republic of the Sudan and the Sudan People's Liberation Movement/Sudan People’s Liberation Army, Nairobi, Kenya 9 January, 2005.

${ }^{1091}$ Comprehensive Peace Agreement, "Machakos Protocol” Signed at Machakos, Kenya on 20th July, 2002 p. 8.

${ }^{1092}$ Comprehensive Peace Agreement between the Government of the Republic of the Sudan and the Sudan People's Liberation Movement/Sudan People's Liberation Army, Nairobi, Kenya 9 January, 2005, p. 74.

${ }^{1093}$ Comprehensive Peace Agreement, “Wealth Sharing” Signed at Naivasha, Kenya on 7 January 2004, p. 54.
} 
expense of the South. We produce oil in our land and Comprehensive Peace Agreement compels us to give fifty percent of it to our enemies. Who benefits from this unity, we must end this method of strengthening the enemy of the people by voting for independence". ${ }^{1094}$ For Galvin and Cooper, social exchange theory suggests that, human beings desire social, economic and political relationships that benefit each party. They value relationships in which rewards are greater than costs and logically, the theory cannot suggest that human beings desire relationships in which the cost outweighs the reward. ${ }^{1095}$

\subsubsection{Attractive unity}

Article 3.2, sub-paragraphs 2.4.2 of the CPA dictate the "Government of National Unity, (GONU) in Sudan to improve institutions and arrangements created, under the agreement in order to make the unity of Sudan attractive to the Christian and Animists of the South". ${ }^{1096}$ The responding Christian and Animist students from the Southern territories unanimously indicate to vote for a separation, because of what some of them call 'dissatisfactions'. They argue that: "There are so many ... political dissatisfactions and we will vote for separation, because of the long bad terms of political, cultural and social relationships between us and the Muslim Arabs in power. Our relationships have been entirely based on discrimination that enslaved and Islamised us. Since the foundation of Sudan, Muslim Arabs at the North held power and arrogantly categorised us in the South to the social category of second-class citizens in our own land. Separation removes all these political inequities ... of Muslim Arabs against us". ${ }^{1097}$ The students continue to say: "The claim at the CPA that unity must be made 'attractive' is nothing. Nothing at all can heal the wounds of racial discrimination for more than one hundred years of slavery". ${ }^{1098}$ One of them concludes: "Who wants to tolerate the harsh rules of the Sharia; I for one, I will vote for the separation and leave them to chop their own limbs with their Sharia". 1099

The claim of racial discrimination between the ruling Islamic North and the 'marginalised' South is one factor threatening the maintenance of the territorial sovereignty of Sudan in 2011.

\footnotetext{
${ }^{1094}$ Atong Riak Akon Riak, a Christian Animist, University of Khartoum.

${ }^{1095}$ Galvin, Kathleen M and Cooper, Pamela J (2003). Making Connections Readings in Relational Communication, Los Angeles: Roxbury Publishing Company, p. 20.

1096 The Machakos Protocol Signed at Machakos, Kenya on $20^{\text {th }}$ July, 2002, p. 8.

${ }^{1097}$ Lam Mel Deng, a Dinka Christian Animist, University of Juba.

1098 Ajok Donato, a Christian Animist, University of Juba.

${ }^{1099}$ Meir Makur, a Dinka Christian Animist, University of Juba, David Arab, a Shilluk Christian Animist, University of Upper Nile.
} 
Addressing a mass rally during an anniversary celebration in Rumbek, the capital city of Lakes State, South Sudan for the foundation of the SPLM and the SPLA, the founder and former head of these organisations, John Garang proclaimed that the challenge now for the Government of Sudan is to make unity attractive to the people of the South Sudan in order for them to vote for unity during the referendum in 2011. If unity is not made attractive, why would any Southerner vote himself or herself to be a second class citizen? Garang concluded that: ... if Sudan does not sufficiently and fundamentally change, why anybody should vote to become a servant, instead of being a master in his or her own independent house". 1100

Additionally, the current President of South Sudan, Salva Kiir Mayardit echoes the same rhetoric on certain occasions. For instance, addressing the Christian worshippers at the cathedral of the Catholic Church in Juba, Mayardit stated: "When you reach your ballot boxes the choice is yours; if you want to vote for unity, so that you become second-class citizens in your own country that is your choice. If you want to vote for independence, so that you are a free person in your independent state that will be your own choice and we will respect the choice of the people". ${ }^{1101}$

'Independence' is a new legal term of Mayardit, rather than 'secession' which is the term used in Part (A) of the Comprehensive Peace Agreement, under the title Agreed Principles. Article (2) with its subheading of 2.5 states "At the end of the six (6) year Interim Period there shall be an internationally monitored referendum, organized jointly by the GoS and the SPLM/A, for the people of South Sudan to: confirm the unity of the Sudan by voting to adopt the system of government established, under the Peace Agreement; or to vote for secession". ${ }^{1102}$ What has influenced Mayardit to suspend the use of 'secession' and adopt 'independence in national forums? According to Rolandsen, Sudan is a colonial construct, where there is little binding the territorial populations of the country together with exception of the shared history of the Condominium rule of the Egyptian and the British. The post-colonial system, however, left these territories unchanged and prescribed handing over power to the political and economic elite of Muslim Arabs in the capital city Khartoum. Under this circumstance, the populations in the peripheries of South Sudan, Nuba Mountains, Darfur, Ingessana and Beja were left with a limited degree of connection to the national structure. Rolandsen concludes that the people of South Sudan define the present power in

\footnotetext{
${ }^{1100}$, Garang, John (2005, May16). Chairman/C-IN-C, SPLM/SPLA, p. 4.

${ }_{1101}$ Salva Kiir Mayardit Address to the Southern Sudanese in the cathedral of the Catholic Church on 29 October 2009.

${ }^{1102}$ Comprehensive Peace (2005, January 9). Comprehensive Peace Agreement between the Government of Sudan and the SPLM/A Kenya Nairobi.
} 
their land as an occupying body with intent to alienate their cultures and promote the slave trade, slavery and plundering resources of their livelihood. ${ }^{1103}$

The description of the presence of the central government institutions in the South as an 'occupying power' with strategies of destruction to cultural identity, slave trade and slavery is an adequate reason for Mayardit to shift from 'secession' to 'independence' as an authentic relevant term to end the 'occupation'. The two terms 'secession' and 'independence' are not explicitly synonymous. According to Yohannes, the former refers to a state within a union of federation or confederation that seeks to secede from the union and the latter refers to the lifting or the decolonisation of occupation from a state. ${ }^{1104}$ Historically, there was no lawful cession of South Sudan sovereignty to the Northern Sudan. It was an abrupt occupation leading to the territorial unity for the interest of power at the expense of the native population. According to Santi and Hill, the Nilotic people of South Sudan migrated from the North and eventually remained untouched by the Islamic North; however, Turkish Captain Salim commanded three river voyages as an attempt to trace the source of the river White Nile in winter of November 1839-42. The unity of the two territories became visible through that voyage for the interest of the Islamic Arab ethnic group slavers, such as Shaiqqyyia and Danagella. These ethnic groups rendered great services to the Turks. Al-Mattamma, a town in the North for notable for its connection to the slave trade derived from the South flourished. "Slaves were sold twice a week" and their "prices differed according to their provenance". ${ }^{1105}$ Santi and Hall conclude that the territorial boundaries were passed to the subsequent systems and the phenomenon of slavery and slave trade continued towards the indigenous population of the South. ${ }^{1106}$

\footnotetext{
${ }^{1103}$ Rolandsen, op. cit., p. 22.

${ }^{1104}$ Yohannes, Okbazghi (1997). United States and the Horn of Africa, Boulder: Westview Press a Division of Harper Collins Publishers, p. 111.

${ }^{1105}$ Santi, Paul and Hill, Richard (trans. eds.) (1980). The European in the Sudan 1834-1878, Some Manuscripts, Mostly Unpublished, Written by Traders, Christian Missionaries, Officials, and Others, Oxford: Clarendon Press, pp. 74-75. ${ }^{1106}$ Ibid.
} 


\section{CONCLUSION}

The successive phases of politics in modern Sudan, since the time of its foundation to present time manifest dynamics of racism and discrimination in national institutions of the state. All the democratic and military systems which have been in power, since the independence of Sudan from Great Britain, until now came from the Islamic-Arab North of Sudan with exception of General Ibrahim Abboud from the Beja of the eastern Sudan. The political logic of all the successive rulers in construction of national identity constitutionally does not consider the existing religious and linguistic diversities of institutions in the country as essential reality. Therefore, it applies an ethnic territorial nationalism model that adopts monolithic religious laws derived from Sharia and imposes Arabic as an official language of working and communication in national institutions of the country. In this way, the non-Muslim and the non-Arab citizens become the victims of religious discrimination and ethnic racism in sharing of power and national wealth. Thus, the majority of students from Darfur, South Sudan, Nuba Mountains and east Sudan of the Beja ethnic group reject this model and some identify it as 'anomia assimilation'. Anomia assimilation is defined as a difficulty that faces an intended person for assimilation to find a word that can describe the measures taken by power in state in eradicating diversity and imposing uniformity of cultures in Sudan. In other words, its application in public institutions creates a difficulty in the mind of an affected person to find a word describing its consequences, because its effects look incongruous to his or her mental and cultural vocabulary. Since, it totally eradicates differences and inserts uniformity by elevating the intended unique culture based on intertwined Islam and Arab among other cultures through different methods, including legal ones as the imposition of Sharia and the use of religious violence in the name of jihad against its opponents.

Specifically, the anomia assimilation is the prime cause of the past and present civil conflicts and wars. The model has been inserted in national institutions on the basis of exclusion and inclusion and subsequently privileged the current population, which identifies itself as Muslim Arabs around Khartoum and far north with education and economic opportunities to the exclusion of the indigenous non-Arab ethnic groups in the South, Nuba Mountains, and Ingessana Hills. These latter areas were categorised or imagined as the regions of slaves. Thus, the political North allowed the Jellaba, Arab Muslim merchants to capture the Black population from these regions for slave trade. In 1898, the British imperialist power overran the last of the slave trading regions in the North and 
introduced strict measures to eradicate the slave trade and all forms of slavery by closing and preventing the entry of Muslim Arabs to the South.

In reaction, the adherents of this model were unhappy about this initiative and to some extent continued to raid for slaves for some time. This raiding situation made it very difficult for the Animists of the South to embrace Islam. Therefore, the Muslim Arabs in Sudan are responsible for the intolerance and resistance of the indigenous ethnic groups of South Sudan to Islam. During the era of the slave trade, the relationships between the imagined categories of 'free Arab Muslims' and the 'slaves' were polarized and a sizable majority of these indigenous people of the South rejected the conversion to Islam. For this reason, the adherents of the anomia assimilation in control of power in the Islamic North constructed the resistant group to conversion as the 'lost brothers'.

Nevertheless, the Christian and Animist students from the South and some from the Nuba Mountains and Darfur reject this constructed stereotype. In their imaginations, the real 'lost brothers' were the ancient Nubians who had their own slave raiding in Christian Kingdoms in the current North Sudan, but were assimilated into an Islamic identity in the fourteenth and fifteenth centuries and currently, most of them identify themselves as Muslim Arabs, instead of African Muslims.

The completely assimilated Nubians to the Islamic-Arab culture have become mostly the adherents of anomia assimilation. The group controls power and never ceased from the project of assimilation of the African cultures into the Islamic-Arab image. It adopts the intertwined IslamicArab culture as the 'imagined' model of homogenising its heterogeneous population in the state. Even though the model has constructed negatively the population in the South as 'the 'African pagans and slaves' it would has functioned successfully, since it had first managed to unify the diverse Muslim-African and Arab inhabitants of the east; far north; west and the centre of Sudan, under one region the 'Muslim Arabs of the Northern Sudan'. However, the adoption of racism that discriminates the non-Arabs within the region has created a dividing line between the Muslim Arabs and Muslim Africans. Muslim Arabs discriminate against the Nuba Muslim Africans in the Nuba Mountains in public institutions and in their common religion, Islam. In their imagination, Muslim Arabs in power treat the Nuba Muslims as dhimmis, protected non-Muslims living within the Islamic society. Such a status qualifies them to be 'second-class citizens'. Arab nationality has been introduced as the determining factor in social, cultural and political institutions, instead of Islam as a unifying faith to all Muslims. The same situation of discrimination in Islam applies to the indigenous African Muslims of Darfur and Beja at the Red Sea. Such imagination makes power in 
the state to favour Muslim Arabs and marginalise Muslim Africans in economic and political dimensions.

These discriminated African groups suspend religion and collectively converge and introduce a counterforce model of resistance. Today, there is a consensus among the Muslim students from the Beja, Darfur and the Nuba Mountains that Islam as a religion is free from this discrimination.

Muslim Arabs adopt discrimination in the distribution of power and sharing of wealth as their own choice and not in accordance to the teaching of the Islamic orthodox. Having been influenced by the presence of discrimination in Islam, some Nuba politicians consequently rebelled and joined the rebellion movement that had sprung up in the territory of the constructed 'pagans and slaves' of the South. The rebels fought the central government under the name of the SPLM and its military wing, the SPLA.

The instances of discrimination within the Islamic religion have created a paradigm of disintegration of the territorial Muslim Arab North. In early 2002, the indigenous Black African population in Darfur rebelled against the central government and founded military and political organisations composed mainly of their indigenous ethnic groups. The first and the largest of these organisations was the Sudan Liberation Army (SLA) and the Sudan Liberation Movement (SLM) followed by the Justice and Equality Movement (JEM). These rebels argue that the ruling Muslim Arabs discriminate against them in sharing power and wealth. They do not consider religion, Islam as the basis of distributing positions and wealth in national institutions, but favour a race, Arab.

In reaction to the insurgents and instead to recruit citizens of Sudan, irrespective of race, ethnic and religion, the government resorted to the racial recruitment in order to confront both of them in Darfur. It constantly recruits the janjaweed (Muslim Arabs) to be its paramilitary soldiers to fight specifically the African Black rebels, but the violence has spread to include the whole Black native civilian population in Darfur. The combined government military operations with the janjaweed have not spared anyone from attack and the killing. And as a result, the attacks have caused a humanitarian disaster for the whole indigenous populations in the region and made hope for peace difficult. This situation shows that the violence has reached the peak of racism, where the janjaweed hunt for the indigenous African Fur, Zagahwa and Massaliet to kill them in their villages. The same situation of discrimination in Islam applies to the indigenous Beja ethnic group living along the Red Sea of the Eastern Sudan, but the scale of violence has not reached the level of humanitarian disaster. The Beja students admit being Muslims, yet they remain as a unique population with their customs totally irrelevant to the Muslim Arabs. The students argue that the Beja people experience discrimination and marginalisation in sharing of power and national wealth. Being pressed by the 
racism of Muslim Arabs in power, the Beja have rebelled, under their ethnic political organisation the 'Beja Congress'.

The political perspective of Sudan shows that racism has created the formation of ethnic political parties in the Northern Islamic territory. The victims of racism and discrimination resort to the reconstruction of their political parties, under the basis of ethnicity, so that marginalisation in power and wealth sharing is addressed through violence. Currently, the students interviewed are divided into two schools as what comes to finding a common constitutional framework that might accommodate the Sudanese ethnic and religious diversity. In their imaginations, some Muslim Arab students demand the adoption of a constitution defined on two parameters, Islam and Arab. Under such a constitution, Sharia is a source of legislature and Arabic is an official language in public institutions. These Muslim students argue that, since Muslims are the majority in Sudan, then it is an obligation for them to revive the Quran and the Sunna politically and culturally. In their imagination, Islam as a religion does not detach culture from a state and Arabic as the language of Quran is to be used in the Muslim state such as Sudan. On the other hand, some Muslims, mostly from the marginal areas of Darfur, Nuba Mountains unite with the Christian-Animists of the South and urge the adoption of a wider constitution that embraces all forms of religious and ethnic diversities. In this way, Sharia would not be a basis for a legislature nor Arabic an official language in the state. In their imagination, the group maintains that the adoption of an Islamic constitution in Sudan is an excuse for one religion in the country to assimilate other religions. Such form of assimilation creates a conflict between the assimilating power and the resisting power. Its imposition by the Islamic rulers in the state leads to the 'anomia assimilation'. Hence, all Christians and Animists with some Muslim students prefer the adoption of a constitutional system that is void of religion. Such a constitution would create a 'gradable assimilation', because it leaves every cultural group to absorb into its cultural values other cultural norms without forceful measures taken by the state constitutionally.

The former President Ja'afer Muhammed Nimeiri has once adopted the 'gradable assimilation' as reflected in a secular constitution after the Addis Ababa Agreement between his government and the former dissidents of the South, the SSLM with its militarily wing, the Anya Nya in 1973. The constitution was secular and it gave equal rights for religions to assimilate each other without interference from the state's power. Religious conflicts arose after Nimeiri abandoned the 'gradable' assimilation and revived the 'anomia' assimilation. He violated the Addis Ababa Agreement by dismantling the Regional Autonomous Government of South Sudan and dividing the 
South into three regions as a means to avoid the unified resistance of the Christian-Animist South to the assimilation.

Current conflicts in Sudan emerged, because of Nimeiri's revival 'anomia' assimilation. Such assimilation represented a gross violation to the agreement and automatically it recycled the conflict, thus, the rebellion resumed in the South, leading to the formation of the SPLM and SPLA against the government of Nimeiri. Nimeiri of courses had by then its political reasons, however, injustice cannot be allowed in order to consolidate or hold power. He abandon 'gradable' assimilation in order to attract support from some new 'status groups' of the 'anomia' assimilation mainly the Islamic political parties of 'Islamic fundamentalism' in Northern Sudan. In September 1983, Nimeiri promulgated on the National Television that the territorial sovereignty of Sudan would apply Sharia as the only source for a constitutional code throughout the country. After the application of Sharia, since that time until today, Sudan became a centre of ideological religious wars. Those who called for the adoption of Sharia were imagined as the 'Muslim fundamentalists' and those Muslims who reject it were labelled as the 'moderate Muslims' and the 'marginalised identities' when the Christians and the Animists are included.

In 1986, the democratic system of multiparty pluralism was revived in Sudan. Sadiq Al-Mahdi from the Umma Party became the Premier in a coalition government with the DUP. The political circumstances forced the new leader to drop 'anomia' assimilation and acquiesce to the 'gradable' assimilation by suspending Sharia, due to peace negotiations with the SPLM. This led to another coup as Brigadier Omer Hassan Al-Bashir seized power on 30 June 1989 calling or imagining the action as Thura el-Ingaz Al-Wathoni (Revolution of National Salvation). Under the new revolution, the scale of 'anomia' assimilation has been too high against the Christian-Animist South and moderate Muslims in the Nuba Mountains and the Ingessana Hills.

During the war that ended in 2005, they were imagined or labelled as 'pagans and apostates'. Jihad was used to justify ethnic cleansing and slavery against them in their areas. The new regime shifted the definition of the war from being a political war to an Islamic war against the 'infidels' of the South and the 'apostates' of the Nuba Mountains and Ingessana Hills of the Southern Blue Nile. This imagined definition was sufficient to introduce radical power restructuring in the national institutions of Sudan, under the name Tawajha el-Hadhari (civilisation project). Those who were seen as displaying resistance to the new Islamic orthodoxy were discharged from public service and members of the Tawajha el-Hathari were installed in their places. The PDF, a militia loyal to the new regime was established to fight the war against the rebels. The members of the PDF were constructed as Mujahedeen (Islamic holy warrior). 
The climax of the 'anomia' assimilation was unveiled in el-Obied the capital city of Northern Kordofan. In 1992, the exploitation of the Islamic religion in defining war was pursued. The government held a conference in el-Obeid to deliberate on the method to be adopted by the new recruits, the PDF and the army in unleashing a war against the defined as 'infidel' rebels. The invitees were mainly selected from the Muslim Arabs in exclusion of the Black African Muslims in Southern Kordofan of the Nuba Mountains. The Muslim Arab imams in the conference were asked to define the war. They unanimously defined it in their imagination as a war between the 'Southern infidels' who cooperated with the Nuba Muslim 'apostates' and started to fight against the Islamic people of Sudan. The imams resorted to Holy Quran and took out verses which could be used in issuing a fatwa, an Islamic legal verdict against the categorised 'apostates and 'infidels'.

In reaction to this fatwa, the Nuba imams and the interviewed students from the region of Nuba Mountains do not imagined themselves as 'infidels'. They denounced the fatwa and described it as un-Islamic, since they too are Muslims. Yet, violence in the name of Jihad spread in the South, Nuba Mountains and Ingessana Hills against the rebels. On the other hand, the adherents of ethnic national pluralism, specifically, the rebels intensified their resistance, under their imagined ideological definition of transforming Sudan into what they called the 'New Sudan'. The SPLM argued that the 'New Sudan' is a framework of a national project for building an authentic and sustainable state for the citizens, capable to embrace inclusively the multiple diversities of Sudan, separating the state from religion and taking secular laws as basic sources of legislature. Thus, each from both sides stood behind its ideological discourses of war and violence that claimed the lives of more than two million people and an unknown number of people were displaced in neighbouring countries or as internal refugees. Generally, the adherents of 'anomia' assimilation are responsible for the perpetual political instability of Sudan. 'Gradable' assimilation is the only alternative approach that can settle these instability problems. It transforms different ethnic and religious groups in Sudan into equal status of citizenship, since it allows each group to freely perform cultural and ethnic activities without coercive measures from the state. Its adoption constitutionally may create opportunities for fair distribution of power and maintenance of peace and stability. It gives a wider space for political competition and building of institutions for all people. Muslim Arab leaders in Sudan with some chieftains of political associations who follow the model of 'anomia' assimilation, which aims to structure institutions within the scope of its ethnic and religious range is an akin to racial democracy, where a political ethnic Muslim fundamentalist loses power in a democratic multiparty contest occasionally resorts to violence of military might in order to stripe power and uses it to control the imaginations of the citizens about themselves. Hence, 
Hassan Abdullah Turabi striped power through the coup headed by President Al-Bashir and in turn, Al-Bashir made another coup against him leading to the rift of their Islamic political party, the NIF into the $\mathrm{NC}$ and $\mathrm{PC}$.

The status quo between the NC and PC shows that in Sudan, some political leaders of ethnic group may fail to achieve their ideological goals through the democratic means and they option violence as an alternative model to keep a tight rein control of power in the state. A group or their leader could be possibly from minority that fears the threat of losing the reign of power in an open democratic multiparty pluralism, where majority may win. He can resort to take arms to confront its other legitimate leader and perhaps for two sheer reasons, first, lust to power and second, maintenance of the imagined ethnic ideologies. In operation, a leader of such minority or majority does not do that alone, instead, each may choose to rely on his or her ethnic and religious group and instigate them in an army to dictate terms of ethnic and religious control. The result of such control has become extremely dangerous for the dynamic co-existence of different ethnic and religious groups in the territorial sovereign Sudan, since it leads to 'anomia' assimilation. Currently, the adoption of 'anomia' assimilation as a model of transforming national institutions in Sudan threatens the territorial sovereignty of the state. After long drawn-out peace negotiations both sides of the conflicting schools accepted the provision of self-determination to the South in a meeting in Machakos, Nairobi in 2002. In January 2005, a final peace treaty was agreed upon and signed leading to the production of the peace document called the CPA. Its provisions call for a referendum in the South to choose between unity with the North or secession from it. There are provisions also which give the Nuba Mountains and Ingessana Hills to exercise 'Popular Consultation' to decide on the current established institutions by the CPA in their regions.

It is noticeable that 'anomia' assimilation has created the challenges for the people of Sudan. First, will Sudan maintain its territorial national identity in 2011, when the population of South Sudan votes in the referendum? It cannot be predicted, however, it would be a decisive moment in the life of an individual person in the South to deliberately contemplate on the advantages and disadvantages of unity, under 'anomia' assimilation and secession. Second, some of the insurgents in Darfur have also recently started in the public media to ask the adoption of self-determination in negotiations with the Government of Sudan. Third, 'the Nuba and Ingessana students are very critical against the 'Popular Consultation', hence, they also vehemently demand the adoption of self-determination to choose between unity and secession from the Islamic North.

Generally, the application of 'anomia assimilation' by power in Khartoum and its resistance to the adoption of 'gradable' assimilation in public institutions poses gradual dis-integration of the country 
into the South, Darfur, Nuba Mountains, Ingessana Hill and Hadarieba states. Therefore, there is a grave need for the adherents of 'anomia' assimilation in power to drop their imagination of the citizens in Sudan as their Muslim-Arab subjects to be governed by the intertwined Islamic-Arab constitution, which treats the citizens, under the basis of religion and ethnicity and allow the legislature to constitutionally enact 'gradable' assimilation laws, which promote ethnic and religious diversity. The adoption of such laws would create a political atmosphere that respects human rights and allows the people of Sudan to interact within their national institutions without religious and ethnic discrimination, which is a source of injustice, racism, discrimination, subordination, oppression and marginalisation of Sudan's fundamental diversity of its religious and linguistic composition that includes the African Muslims and the African Christian-Animists. Such political structural model builds a political institution of religious freedom, where an Arab or an African Muslim believer goes to a mosque on Friday and an African-Christian-Animist attends divine services in a church on Sunday or engages in Animist rituals of libation on a shrine or a sanctuary, yet, each one of them imagines others as equal-free citizens of Sudan before the constitutional law in the country. 


\section{ACKNOWLEDGEMENTS}

I wish to register my profuse thanks to my main supervisor Professor Dr. Risto Marjomaa at the University of Helsinki, Finland. His vision, advice and professional comments on the progress of the dissertation were very beneficial.

I am also extremely indebted to thank my external examiner and opponent, Professor Dr. Anne Storch of Cologne University, Germany for her positive comments. At the same category, I feel indebted also to my co-supervisor, Professor Dr. Axel Fleisch at the Department of World Cultures, University of Helsinki. On different sessions, Fleisch has been helpful.

I appreciate the friendship and professional collaboration of my colleagues at the Department of World Cultures, University of Helsinki, especially Aleksi Järvelä, Miika Pölkki, Janne Mattlia, Maria Pakkala, Erika Sandman, MariaYilmazkurtdag and Maria Colliander. Their stable encouragements, while sitting and interpreting the research data in the office at the University of Helsinki were indeed, remedial to stress of working burdens.

I thank my brother Professor Dr. Jok M. Jok of the Loyal Marymount University, Los Angeles, USA for his honest support. Jok bought for me the relevant books which were used as secondary literature for the study. I must offer my thanks to Professor Dr. Juhani Koponen and Docent, Dr. Pertti Multanen of the Institute of Development Studies at the University of Helsinki. Both have been very supportive, in terms of references and the search for the related theories to the research main question(s). In terms of research fieldwork in Africa, my thanks go to the Nordic African Institute, Uppsala, Sweden, Finn Church Aid, Helsinki, Finland and the Evangelical Lutheran Congregation of Vantaa, Finland for the scholarships.

Last, but not least, my special thanks go to my family, Achai Deng Kuol Arob and my son Jok as well as to my Finnish mother Maija Kajava for their constant encouragement and patience during my engagement in the study. 


\section{GLOSSARY}

Abid

Aci khor

Al-figh

Allah

Al-Sudd

Al-Sultanate al-Zerga

Amir el Mumeneen

Asmer

Bilad Al-Sudan

Caliph

Dar Al-hareb

Dar Al-Islam

Dhimmi

Faqih an Islamic

Fatiha

Fatwa

Hadith

Hakimdar

Haram

Hayawan al-natigq

Houris

Hudud

Hurr al-Dunia

Hurr al-jinna
Slave

Adulteress or someone who has committed adultery in

Dinka language

Islamic jurisprudence

God

Black people

Black Kingdom.

An Islamic pious leader of Muslim believers

Brown colour

Land of the Blacks.

An Islamic successor.

Domain of war

Land of peace

A term that Muslims use to identify a non-Muslim living in Muslims' land, under protection.

Religious person

An introductory part of Quran

Islamic legal edict

Sayings and actions of the Prophet Muhammed

General Governor

Strictly not allowed

A derogatory term Muslim Arab use to define a Black

person in Sudan to mean a speaking animal

Assumed paradise virgin women

A formal Islamic legal code that stones to death a woman proved guilty of adultery, amputates cross limbs of a thief found guilty of stealing; flogs any person found drunk with alcohol

Dark eyed virgins of the earth

Dark eyed virgins of the paradise 
Imam

Iris al-Shaheed

Istihsän

Isum Ajami

Janjaweed

Jellaba

Jihad

Jihadists

Jin

Junubi

Kasha

Kawaja

Kawajat

Khar

Khor

Kiirtoum

Kuffar

Kujur

La Illa’ ila Allah

Muhammed Rasul Allah

Mekks

Mou

Mujahedeen

Murtadeen

Nazareen

Nhialic

Nhialic agur abik
Pious Islamic cleric

Wedding of Islamic martyrs

Jurist preference

A non-Arab name.

Arab Muslim militia in Darfur

A term the indigenous population uses to distinguish an

Arab Muslim merchant or many of them including Muslim

Arab administrators in Sudan

Islamic holy war

Islamic holy warriors

Devil

A derogatory name for a person emerging from South

Sudan and literary means a Southerner.

A legalised search for an indigenous ethnic person from the South, Darfur and Nuba Mountains residing in Khartoum to be arrested and sent back to an original area

White person

White people

A branch of a river Nile in accordance to the Nilotic of Sudan.

A Dinka term for adultery

Khartoum in accordance to the Nilotic people of Sudan.

Infidels or pagans

A derogatory definition of the African religious rites

There is no God, but God One God and Muhammed is

God's Messenger

Nuba Muslim leaders

Alcohol or liqueur in Dinka language

Islamic holy warriors

Apostates

Name used by Muslims to mean Christians

A Dinka term for God or Lord.

A Dinka proverb 'God is grinding flour' to mean living in 
hope that God gives

Niqab

It is a long piece of cloth that cloaks a Muslim woman

body over head to toe with a small patch open to see

Ramadan

Holy month of fasting in Muslim calendar

Ray

Opinion

Sharia

Islamic law

Sheikh

A Muslim leader

Shura

Islamic consultation.

Sudds

Swamps of the White Nile

Sunna

Examples and precedents of the Prophet Muhammed

Sunni

Islamic sect

Tawajha Al-hathari or

Both are synonymous terms refer to the orientation project

Mashurua Al-hathari

to strict Islamic orthodoxy

Thudan

A specific name for Sudan in accordance to the Nilotic people of Southern Sudan

Thudaniith

The Nilotic's pronunciation to the term Sudanese

Thura Al-Ingaz Al-Watoni National Salvation Revolution

Toum

Confluence of the rivers, White and Blue Niles.

Tujjar ad-din

Traders of religion

Umma

Nation of Islam.

Zerga

Blue colour 


\section{BIBLIOGRAPHY}

Books

Abd Al-Rahim, Muddathir "Arabism, Africanism, and Self-identification in the Sudan", in Dunstan M Wai (ed.) (1973). The Southern Sudan the Problem of National Integration.

African Rights (1995). Facing Genocide: The Nuba of Sudan, London: African Rights Publication.

Alexander, C. Jaffery (1987). Sociological Theory since 1945, London: Columbia University Press.

Alier, Abel (1990). Southern Sudan: Too Many Agreements Dishonored, Reading: Ithaca Press.

Alier, Abel "The Southern Sudan Question” in Dunstan M Wai (ed.) (1973). The Southern Sudan the Problem of National Integration, London: Frank Cass.

Alier, Abel "What is the Solution to the Constant Conflict in Sudan?" In Martin Doornbos, et al. (eds.) (1992). Beyond Conflict in the Horn. The Prospect for Peace, Recovery, \&Development in Ethiopia, Somalia, Eritrea, \& Sudan, The Hague: Institute for Social Sciences.

Al-Shahi, Ahmed "The Distinctiveness of the Shaiqqyyia Tribe of Northern Sudan: Complexity and Continuity" in Herve Bleuchot Hopwood (ed.) (1991). Sudan History, Identity, Ideology, Oxford: Ithaca Press.

Anderson, Benedict (1991). Imagine Communities Reflections on Origins and Spread of Nationalism (rev. ed.), London: Verso.

Anderson, G Norman (1993). Sudan in Crisis, the Failure of Democracy, Gainesville: University Press of Florida.

Ankumah, Evelyn A (1996). The African Commission on Human and People's Rights Practice and Procedures, Hague: Kluwer.

An-Na'im, Abdullahi Ahmed (ed.) (1993). Proselytization and Communal SelfDetermination in Africa, New York: Maryknoll.

An-Na'im, Abdullahi Ahmed "Competing Claims to Religious Freedom and Communal Self-Determination in Africa”, in Abdullahi Ahmed An'Naim (ed.) (1993). Proselytization and Communal Self-Determination in Africa, New York: Maryknoll.

An-Na'im, Abdullahi Ahmed (1990). Toward on Islamic Reformation: Civil Liberties, Human Rights and International Law, New York: Syracuse University Press.

An-Na'im, Abdullahi Ahmed (1992). Human Rights in Cross Cultural Perspective, Quest for Consensus, Philadelphia: University of Pennsylvania.

Ansari, Sara (1992). Sufi Saints and State Power: The Pirs of Sinds, Cambridge: Cambridge University Press.

Antalöv, Hans and Ngo, Tak-Wing (eds.) (2000). The Cultural Construction of Politics in Asia, Surrey: Curzon. 
Antuon, Richard T. and Hegland, Mary Elaine (eds.) (1987). Religious Resurgence, Contemporary Cases in Islam, Christianity, and Judaism, Syracuse: Syracuse University Press.

Aziz, Zahid (2007). Islam Peace and Tolerance, Middlesex: Ahmadiyya Anjuman Lahore Publications.

Baldwin, John D (1986). George Herbert Mead: A Unifying Theory for Sociology, California: Sage.

Barth, Fredrik (1969). Ethnic Groups Boundaries, Boston: Brown and Company.

Bass, Alan (tran. and ed.) Jacques Derrida (1987). Writing and Difference, Chicago: Chicago University Press.

Bauman, Zygmunt (1990). Thinking Sociologically, Oxford: Basil Blackwell Ltd.

Beeman, William O (2001). "Fundamentalism ---Origins. Fighting the Good Fight: Fundamentalism and Religious Revival" in J Mac Clancy (ed.) Anthropology for the Real World, Chicago: University of Chicago Press.

Beswick, Stephanie F (2004). Sudan's Blood Memory, the Legacy of War Ethnicity, Slavery in Early South Sudan, New York: University of Rochester.

Bok, Francis and Tivnan, Edward (2003). Escape from Slavery, the True Story of My Ten Years in Captivity and My Journey to Freedom, New York: St Martin's Press.

Bourdieu, Pierre (1977). A Theory and Practice, London: Cambridge University.

Brown, Daniel (1996). Rethinking Tradition in Modern Islamic Thought, Cambridge: Cambridge University Press.

Brown, Daniel (2004). A New Introduction to Islam, Oxford: Blackwell Publishing Ltd.

Brink, Andre (1983). A Chain of Voices, London: Fontana.

Burr, J Millard and Collins, Robert O (1995). Requiem for the Sudan War, Drought, Disaster Relief on the Nile, Boulder: Westview Press.

Calhoun, Craig (1995). Critical Social Theory: Culture, History, and the Challenge of Difference (Twentieth-Century Social Theory, New Jersey: Wiley-Blackwell.

Clapham, Andrew "United Nations Charter-Based Protection of Human Rights" in Katarina Krause and Martin Scheinin (2009). International Protection of Human Rights, a Textbook, Åbo: Åbo Akademi University.

Cheadole, Don and Prendergast, John (2007). Not on Our Watch: The Mission to End Genocide in Darfur and Beyond, Washington: Hyperion Books.

Clarke, Peter (ed.) (1990). The World's Religion Islam, London: Routledge.

Collins, Robert O (1962). The Southern Sudan, 1883-1898 a Struggle for Control, London: Yale University Press.

Collins, Robert O (1999). "Africans, Arabs, and Islamists: From the Conference Tables to Battlefields in the Sudan, African Studies Review, African Studies Association, Vol. 42 No. 2, p. 107-124.

Collins, Robert O and Deng, Francis Mading (eds.) (1984). The British in the Sudan 1898-1956, Stanford: Stanford University. 
Clausewitz, Karl von (1968) On War, Harmonthsworth: Penguin

Cunningham, Frank (2002) Theories of Democracy a Critical Introduction, London: Routledge.

Daly, Martin W (1986). Empire on the Nile: The Angelo Egyptian Sudan 1898-1934. Cambridge: Cambridge University Press.

Deng, Francis Mading (1995). War of Visions Conflict of Identities in the Sudan, Washington D.C: Brookings Institution.

Deng, Francis Mading (1978). Africans of Two Worlds the Dinka in Afro-Arab Sudan, New Haven: Yale University Press.

Deng, Francis Mading "Scramble for Souls: Religious Intervention among the Dinka in Sudan", in Abdullahi Ahmed An-Na'im (ed.) (1993). Proselytization and Communal Self Determination in Africa, New York: Mary knoll.

Deng, Francis Mading (1989). Cry of the Owl, New York: Lillian Barber Press.

Deng, Francis Mading (1970). Tradition and Modernization among the Dinka: A Challenge for Law, New Haven: Yale University Press.

Deng, Francis Mading (1980). Dinka Cosmology, London: Ithaca.

de Waal, Alex (2004) Islamism and Its Enemies in Horn of Africa, Addis Ababa: Shama Books.

Denoon, Donald, "The Education of Southern Sudanese Refugees", in Dunstan M. Wai (ed.) (1973). The Southern Sudan the Problem of National Integration, London: Frank Cass.

Denzin, Norman K (1989). Interpretive Interactionism, Applied Social Research Methods Series Vol. 16, Newbury Park: Sage Publications.

de Vause, D A (1986). Surveys in Social Research, London: George Allen \& Unwin.

Durkheim, Emile (1895). Rules of Sociological Method in George E. Catlin (ed.) Sarah A. Solova and john H. Mueller (trans.) (1964). Major Works of Emile Durkheim, New York; Free Press.

Erlich, Haggi (2002). The Cross and the River Ethiopia, Egypt and the Nile, London: Lynne Rienner Publishers.

Elsiddig, Elnour Abdalla (2007). Jebal Marra Potentials for Resources and Rural Development in Darfur, Khartoum: University of Khartoum, Khartoum University Press.

Esler, Philip (1971). Conflict and Identity in Romans the Social Setting of Paul's Letter, Minneapolis: Augsburg Fortress.

Evans-Pritchard, Evans (1940). The Nuer a Description of the Modes of Livelihood and Political Institutions of a Nilotic Peoples, Oxford: Oxford University Press.

Ewald, Janet J (1990). Soldiers, Traders, and Slaves State Formation of Economic Transformation in the Greater Nile Valley 1700-1885, Wisconsin: University of Wisconsin Press.

Fage, John Donnelly (1978). A History of Africa, New York: Alfred Knopf. 
Fallers, LIoyd A (1973). Inequality Social Stratification Reconsidered, Chicago: The University of Chicago Press.

Fisher, Humphrey J (2001). Slavery in the History of Muslim Black Africa, London: Hurst and Company.

Fluehr- Lobban, Carolyn (1987). Islamic Law and Society in the Sudan, London: Frank Cass.

Foucault, Michel Power/Knowledge in Colin Gordon (ed.) (1980). Power Knowledge: Selected Interviews and Other Writings, New York: Pantheon Books.

Fowler, Jr Floyd J (1984). Survey Research Method, London: Sage Publications.

Fox, Jonathon (2004). Religion, Civilization, and Civil War 1945 through the New Millennium, New York: Lexington Book.

Fromkin, Victoria and Rodman, Robert (1993). An Introduction to Language, $\left(5^{\text {th }}\right.$ ed.), Philadelphia: Harcourt Brace College Publishers.

Galvin, Kathleen M and Cooper, Pamela J (2003). Making Connections Readings in Relational Communication, Los Angeles: Roxbury Publishing Company.

Graham, Bruce (1990). Hindu Nationalism and Indian Politics, Cambridge: Cambridge University Press.

Garang, John de Mabior in Mansur Khalid (ed.) (1996). John Garang Speaks, New York: Kegan Paul International.

Gray, Richard (1961). A History of the Southern Sudan 1839-1889, Oxford: Oxford University Press.

Guba Egon G Lincoln, Yuonna S "Competing Paradigms in Qualitative Research" in Norman K. Denzin and Yuonna S Lincoln (eds.) (2003). The Landscape of Qualitative Research Theories and Issues, London: Sage Publications.

Gudykunst, William B (1995). Communication in Personal Relationships across Cultures, Thousands Oaks: CA: Sage.

Haddon, Alfred (1934). History of Anthropology, London: Watts \& Co.

Haralambos, Michael and Heald, R M (1981). Sociology: Themes and Perspectives, Oxford. Collins Educational.

Hale, Sondra (1997). Gender Politics in Sudan, Islamism, Socialism, and the State, Boulder: Westview Press, a Division of HarperCollins Publishers, Inc.

Hall, Stuart, "Race, Articulation, and Societies Structure in Dominance", in Stuart Hall (1980). Sociological Theories: Race and Colonialism, Paris: UNESCO.

Hall, Stuart "The Question of Cultural Identity” in Stuart Hall, et al. (eds.) (1991). Modernity and Its Futures, London: Polity Press in Association with Open University.

Hall, Stuart (1987). 'Minimal Selves', in Identity: The Real me, ICA Document 6 London: Institute for Contemporary Arts.

Hassan, Gubara Said (2007). Western Sudan's Darfur Region: Conflict, Humanitarian Crisis and Post Conflict Reconstruction, Helsinki: University of Helsinki Acta Politica. 
Harding, Sandra (1986). The Science Question in Feminism, New York: Cornell University Press.

Harris, Marvin (1987). Cultural Anthropology, New York: Harper and Row Publishers.

Hastings, Adrian (2004). The Construction of Nationhood, Ethnicity, Religion, and Nationalism, Cambridge. Cambridge University Press.

Hatch, J Amos (2002). Doing Qualitative Research in Education Settings, New York: State University of New York Press.

Hatch, Mary Jo (2006). Organisation Theory, Modern, Symbolic, Postmodern Perspectives, Oxford: Oxford University Press.

Hawley, John Stratton (ed.) (1994). Fundamentalism and Gender, New York: Oxford University Press.

Health, John Everett (2005). Concise Dictionary of the World Place-Names, Oxford: Oxford University Press.

Hedrick, Terry E et al. (1993). Applied Research Design a Practical Guide, London: Sage Publications.

Heywood, Andrew (2003). Political Ideologies an Introduction (3rd ed.), Hampshire: Palgrave Macmillan.

Hirschman, Jane R and Munter, Carol H (1988). Overcoming Overeating Living Free in a World of Food, Massachusetts: Addison Wesley Publishing Company Inc.

Herskovits, Melville J (1961). Human Factor in Changing Africa, Toronto: Alfred A. Knopf, Inc.

Hilgard, Ernest R (1962). Introduction to Psychology ( ${ }^{\text {rd }}$ ed.), New York: Harcourt, Brace \& World, Inc.

Holy Bible (1990). Holy Bible the New King James Version, New York: American Bible Society.

Holy Quran (1998). Holy Quran, Lefahan: Amir-Ful-Mu'mineen Ali Library.

Holt, P M. and Daly, Martin W (1989). The History of the Sudan, Boulder: Westview.

Hobsbawm, Eric John and Ranger, Terrence (eds.) (1983). The Invention of Traditions, Cambridge: Cambridge University Press.

Horrie, Chris and Chippindale, Peter (1997). What Is Islam a Comprehensive Introductory, London: Virgin Books.

Huysmans, Jef "Migrants as a Security Problem: Dangers on Securitizing' Societal Issues, in Robert Miles and Dietrich Thränhardt (eds.) (1995). Migration and European Integration the Dynamics of Inclusion and Exclusion, London: Pinter Publishers Ltd.

Idris, Amir Hassen (2001). Sudan's Civil War, Slavery, Race and Formation of Identities, New York: Edwin Mellen Press Ltd.

Ingpen, Robert and Wilkinson, Philip (1994). A Celebration of Customs and Rituals of the World, Surrey: Dragon's World Ltd. 
Iyob, Ruth and Khadiagala, Gilbert M (2007). Sudan the Elusive Quest for Peace, London: Lynne Rienner Publishers.

Janis, Irving (1972). Victims of Groupthink, Boston: Houghton Mifflin.

Johnson Douglas Hamilton “The Sudan People's Liberation Army \& the Problem of Factionalism" in Christopher Clamham (ed.) (1998). African Guerrillas, Bloomington: Indianan University Press.

Jok, Madut Jok (2001). War and Slavery in Sudan, Philadelphia: University of Pennsylvania Press.

Karn, Harry W and Weitz, Joseph (1955). An Introduction to Psychology, New York: John Willey \& Sons INC.

Karklins, Rasma (1994). Ethnopolitics and Transition to Democracy: The Collapse of USSR and Latvia, Washington: Woodrow Wilson Center Press.

Keesing, Roger M and Strathern, Andrew J (1998). Cultural Anthropology a Contemporary Perspective ( $3^{\text {rd }}$ ed.), New York: Harcourt Brace \& Company.

Khalid, Mansour (1987). The Government They Deserve: The Role of the Elite in Sudan's Political Evolution, New York: Kegan Paul International

Khilnani, Suni "The Development of Civil Society" in Sudipata Kaviraj and Sunil Khilnani (eds.) (2001). Civil Society History and Possibilities, Cambridge: Cambridge University Press.

Kebbede, Girma (ed.) (1999). Sudan's Predicament Civil War, Displacement and Ecological Degradation, Hampshire, Ashgate Publishing Limiting.

Kelsay, John (1993). Islam and War a Study in Comparative Ethics, Westminster: John Knox Press.

Kochmann, Karl (1994). Clock \& Watch Trade Index of European Origin, Concord: Antique Clocks Publisher.

Kok, Peter Nyot (1996). Governance and Conflict in the Sudan, 1985-1995, Hamburg: Deutsches Orient-Institut.

Kvale, Steinar (1996). Interviews an Introduction to Qualitative Research Interviewing, London: Sage Publications.

Langley, Winston E (1992). Human Rights Sixty Major Instruments, North Carolina: McFarland \& Inc Publishers.

LeCompte, Magarete D and Preissle, Judith (1993). Ethnography and Qualitative Design in Educational Research ( $2^{\text {nd }}$ ed.), San Diego CA: Academic Press.

Lemert, Charles, (1997). Social Things: An Introduction to the Sociological Life, New York: Rowman and Littlefield.

Leopold, Mark (2005). Inside West Nile, Violence History \& Representation on an African Frontier, Oxford: James Currey.

Lesch, Ann Mosely (1998). The Sudan: Contested National Identities, London: James Currey.

Lewis, Bernard (1990). Race and Slavery in the Middle East, Oxford: Oxford University press. 
Locke L Spirduso et al. (1993). Proposals that Work (3rd Ed.), Newbury Park: CA: Sage.

Lunde, Paul (2002). Islam Faith, Culture, History, London: Dorling Kindersley Limited.

Malwal, Bona (1981). People and Power in Sudan: The Struggle for Stability, London: Ithaca.

Malwal, Bona Madut "Racism, Cultural and Religious Bigotry" in Martin Doornbos et al. (eds.) (1992). Beyond Conflicts in the Horn: The Prospect for Peace, Recovery \& Development in Ethiopia, Somalia, Eritrea \& Sudan, The Hague: Institute of Social Sciences.

Mangione, Thomas W (1995) Mail Surveys Improving the Quality, London: Sage Publications.

Mann, Nicholas (1993). Atlas of Renaissance, London: Cassell Villiers House.

Marjomaa, Risto (1998). War on the Savannah the Military Collapse of the Sokoto Caliphate under the Invasion of the British Empire 1897-1903, Helsinki: the Finnish Academy of Science and Letters.

Marler, Penny Long "Religious Change in the West: Watch the Women" in Aune, Kristine et al. (2008). Women and Religion in the West Challenging Secularization, Hampshire: Ashgate.

Marshall, Thomas Humphrey (1973). Class, Citizen, and Social Development, London: Greenwood Press.

Marsh, Catherine (1982). The Survey Method: the Contribution of Surveys to Sociological Explanation, London: George Allen and Unwin.

Martin, Paul and Winner, Harry "Religious Proselytization Historical and Theological Perspectives at the End of the Twentieth Century", in Abdullahi Ahmed An'Naim (ed.) (1999). Proselytization and Communal Self-Determination in Africa, New York: Mary knoll.

Maxwell, Joseph A (1996). Qualitative Research Design an Interactive approach, London: Sage Publications.

Meyer, Gabriel (2005). War and Faith in Sudan, Michigan: William b Eerdmans Publishing Company.

Miles, Robert (1993). Racism after Race Relations, London: Routledge

Miles, Robert (1989). Racism, London: Routledge.

Miles, Robert and Brown, Malcolm (2004). Racism, (2 ${ }^{\text {nd }}$ ed.) London: Routledge Taylor and Francis Group.

Miles, Robert and Thränhardt, Dietrich (eds.) (1995). Migration and European Integration the Dynamics of Inclusion and Exclusion, London: Pinter Publishers Ltd.

Mills, C Wright (1959). The Sociological Imagination, Oxford: Oxford University Press.

Mawut, Lazarus Leek (183). Dinka Resistance to Condominium Rule 1902-1932, Khartoum: University of Khartoum Press. 
Mohammad, Hassan Makki (1989). Sudan: The Christian Design, London: Islamic Foundation.

Mahmud, Ushari Ahmed and Baldo, Suleyman Ali (1987). The Dhein Massacre Slavery in the Sudan, London: Sudan Relief and Rehabilitation Association.

Miller, David L (1973). George Herbert Mead, Self, Language and the World, Chicago: Chicago Press.

Montagu, Ashley (1972). Statement on Race, London: Oxford University Press.

Morris, Brain (1987). Anthropological Studies of Religion and Introductory Text, London: Cambridge University Press.

Morris, Charles W (ed.) (1933). Mind and society, Chicago: Chicago Press.

Moore, James "The Creationist Cosmos of Protestant Fundamentalism" in Martin E Marty and R Scott Appleby (eds.) (1993). Fundamentalism and the Society Declaiming the Sciences, the Family, and Education, Chicago: the University of Chicago Press.

Muhlhäusler, Peter (1986). Pidginand Creol Linguistics, Oxford, Basil Blackwell.

Murdock, George (1949). Social Structure, New York: Macmillan.

Mushanga, Timbamanyamwene (ed.) (2004). Criminology in Africa ( $\left.1^{\text {st }} \mathrm{ed}.\right)$, Kampala: Fountain Publishers.

Nandy, Ashis (1997). Creating Nationality the Ramjanmabhumi Movement and Fear of the Self, Oxford: Oxford University Press.

Nazer, Mende and Lewis, Damien (2004). Slave, the True Story of Girl's Lost Childhood and Her Fight for Survival, Helsinki: Otavan Kirjapaino Oy.

Nikkel, Marc R (2001). Dinka Christianity the Origin and Development of Christianity among the Dinka of Sudan with the Special Reference to the Song of Dinka Christians, Nairobi: Paulines Publications Africa.

Nor, Adam Baballa Haroun (1999). "Ethnic Composition, Economic Pattern and Armed Conflicts in Darfur", the Sudanese Human Rights Organization, the Sudanese Human Rights Quarterly, Issue No. 8, pp. 1-25.

Nyerere, Julius Kabarage (1977). Ujamaa: Essays on Socialism, London: Oxford University Press.

Nye, Malory (2003). Religion the Basics, London: Routledge.

O'Fahey, Rex Sean and Spaulding Jay L (1974). Kingdoms of Sudan, London: Methuen \& Co. Ltd.

Obeyesekere, Gananath, "Buddhism, Nationhood, and cultural Identity: A Question of Fundamentals" in Marty Martin E and R Scott Appleby (eds.) (1995). The Fundamentalism Project Volume Five, Chicago: University of Chicago Press.

Omi, Michael and Winant, Howard (eds.) (1994). Racial Formation in the United States from 1960s to 1990s ( $2^{\text {nd }}$ ed.), London: Routledge.

Pavan, Aldo (2010). The Nile from the Mountains to Mediterranean, London: Thames \& Hudson.

Park, Robert Ezra (1950). Race and Culture, Glencoe III. 
Petterson, Donald (2003). Inside Sudan Political Islam, Conflict and Catastrophe Revised and Updated, Oxford: Westview.

Phadnis, Urmila (1989). Ethnicity and Nation- Building in South Asia, New Delhi: Sage Publications.

Prunier, Gerard (2007). Darfur the Ambiguous Genocide, London: Hurst \& Company.

Prunier, Gerard (2004). "Rebel Movements and Proxy Warfare: Uganda, Sudan and the Congo 1986-99", African Affairs, the Journal of the Royal African Society, Vol. 103 No., 412, pp.382- 412.

Poynton, Sir Hilton "The View from the Colonial Office" in A H M Kirk-Greene (ed.) (1979). Africa in the Colonial Period the Transfer of Power the Colonial Administrator in the Age of Decolonisation, Oxford: Oxford University Press.

Preece, Jeniffer Jackson (1998). "Ethnic Cleansing as an Instrument of Nation-State Creation Changing State Practices and Evolving Legal Norms, Human Rights Quarterly, Vol. 20 No. 4, p. 822-1004.

Rifat, Sid Ahmed (1989). Munathat Al-Islamia el-Zaej fil Sabaeennaat (Arabic) The Islamic Anger Organisations of Seventies, Cairo: Madbuli.

Robertson, Ian (1978). Sociology, ( $3^{\text {rd }}$ ed.), New York: Worth Publishers.

Robertson, Ian (1981), Sociology ( $2^{\text {nd }}$ ed.), New York: Worth publishers.

Rochon, Thomas (1998). Culture Moves, London: Princeton University Press.

Rolandsen, Oystein H (2005). Guerrilla Government Political Changes in the Southern Sudan during the 1990s, Uppsala: Nordiska Afrikan Institutet.

Rone, Jemera (1996). Behind the Red Line Political Repression in Sudan, New York: Human Rights Watch.

Rorty, Richard (1989). Contingency, Irony and Solidarity, Cambridge: Cambridge University Press.

Rosaldo, Renato (1989). Culture and Truth: The Remaking of Social Analysis, Boston: Beacon.

Said, Beshir Mohammed (1956). The Sudan Crossroads of Africa, London: The Bodley Head.

Sakaranaho, Tuula (2006). Religious Freedom, Multiculturalism, Islam, Cross Reading Finland and Ireland, Muslim Minorities Volume 6, Leiden: Martinus Nijhoff Publishers and VSP.

Sanderson, Lilian Passmore and G N Sanderson (1983). Education, Religion and Politics in Southern Sudan, London Ithaca.

Santi, Paul and Hill, Richard (trans. eds.) (1980). The European in the Sudan 18341878, Some Manuscripts, Mostly Unpublished, Written by Traders, Christian Missionaries, Officials, and Others, Oxford: Clarendon Press.

Schraeder, Peter J "Promoting International Community of Democracies" in Peter J Schraeder (ed.) (2002). Exporting Democracy Rhetoric vs. Reality, London: Lynne Rienner Publishers. 
Scott-Kakures, Dion et al. (1993). History of Philosophy Why, New York: Harper Perennial.

Sidahmed, Abdel Salam and Ehteshami, Anourshiravan (eds.) (1996). Islamic Fundamentalism, Oxford: Westview Press.

Sidahmed, Abdel Salam (1997). Politics and Islam in Contemporary Sudan, Surrey: Curzon Press.

Seidman, Steven (1991). The End of Sociological Theory: The Postmodern Hope, Sociological Theory, American Sociological Association, Vol. 9, No. 2, pp. 131146.

Simone, T. Abdou Maliqalim (1994). In Whose Image? Political Islam and Urban Practices in Sudan, Chicago: The University of Chicago Press.

Simpson, George E and Yinger, Milton J (1985). Racial and Cultural Minorities: An Analysis of Prejudice and Discrimination $\left(5^{\text {th }} \mathrm{ed}\right.$.), New York: Plenum.

Slater, Philip (1955). Role Differentiation in Small Groups, New York: Knofp.

Smith, Anthony D (1986). The Ethnic Origins of Nations, New York: Blackwell.

Smith, Philip (2001). Cultural Theory an Introduction, New York: Blackwell Publishers.

Steinberg, Stephen (1989). The Ethnic Myth Race, Ethnicity, and Class in America, Boston: Beacon Press.

Stevenson, R C (1984). The Nuba of Southern Kordofan, Ethnographic Survey, Khartoum: University of Khartoum Press.

Stouthamer-Loeber, Magda and van Kammen, Welmoet (1996). Data Collection and Management a Practical Guide, London: Sage Publications.

Suliman, Mohamed Suliman (ed.) (1999). Ecology, Politics, and Violent Conflict, London: Zed Book.

Sumbeiywo, Lazaro (2006). The Mediator General Lazaro Sumbeiywo and the Southern Sudan Peace Process, Nairobi, Kenway Publications.

Sylvester, Anthony (1977). Sudan under Nimeiri, London: Bodley Head.

Taha, Mahmoud Mohamed (1987). The Second Message of Islam (Trans.), Abdullahi Ahmed An'Naim, New York: Syracuse University Press.

Suliman, Mohamed (ed.) (1999). Ecology Politics and Violence Conflict, London: Zed Book.

Van der Veer, Peter (1994). Religious Nationalism. Hindus and Muslims in India, Berkeley: University of California Press.

Vanderhoofforschner, Karen (2003). Everything You Need to Know about the Lyme disease and Other Tick-Borne Disorders ( $2^{\text {nd }}$ ed.), New Jersey: John Wiley \& Sons Inc.

Voll, John Obert and Sarah Potts Voll (1985). Sudan: Unity and Diversity in a Multicultural State, Boulder: Westview.

Voll, John Obert (ed.) (1991). Sudan: State and Society in Crisis, Bloomington: Indiana University Press. 
Wai, Dunstan M (ed.) (1973). The Southern Sudan the Problem of National Integration, London: Frank Cass.

Wai, Dunstan M (1980). "Pax Britannica and the Southern Sudan, the View from the Theatre", African Affairs, the Journal of the Royal African Society, Vol. 79 No. 316, pp. 375-395.

Warburg, Gabriel (2003). Islam, Sectarianism and Politics in Sudan since the Mahdi, Madison: The University of Wisconsin Press.

Warburg, Gabriel (1978). Islam, Nationalism in a Traditional Society: The Case of Sudan, London: Frank Cass.

Weber, Max (1958a) The Protestant Ethic and Spirit of Capitalism, New York: Scribner's.

Weber, Max (1963). The Sociology of Religion, Boston: Beacon Press.

Weber, Max (1970). From Max Weber: Essays in Sociology H. H Gerth and C.Wright Mills (Trans. eds.), London: Routledge \& Kegan Paul LTD.

Whitehouse, Harvey (1995). Inside the Cult Religious and Innovation Transformation in Papua New Guinea, Oxford: Clarendon.

William, Edgett Smith (ed.) (1971). We must Run while They Walk, New York: Random House.

Wilson, Bryan (1991). Secularization and Rationalization, Oxford: Oxford University Press.

Woodward, Peter “A 'New Sudan'?” in Herve Bleuchot et al. (eds.) (1991). Sudan, History, Identity, Ideology, Oxford: Ithaca Press.

Yinger, J Milton (1994). Ethnicity Source of Strength? Source of Conflict?, New York: State University of New York Press.

Yohannes, Okbazghi (1997). United States and the Horn of Africa, Boulder: Westview Press a Division of Harper Collins Publishers.

Yongo-Bure, Beniah "Economic Reforms in South Sudan" in Martin Doornbos et al (eds.) (1992). Beyond Conflicts in the Horn: The Prospect for Peace, Recovery \& Development in Ethiopia, Somalia, Eritrea \& Sudan, The Hague: Institute for Social Sciences.

Yule, George (1985). The Study of Language, London: Oxford University Press.

Zinn, Howard (rev. ed.) (2003). A People's History of the United States, New York: Association of Schools Librarians.

Academic Journals

An'Naim, Abdullahi Ahmed (Summer, 2003). "Re-affirming Secularism for Islamic Societies", New Perspective Quarterly, Vol. 7.

Badal, Raphael K (2006, May). "Traditional Resolutions of Local Conflicts in Dar Fur", Mahawer, a Journal for Sudanese Studies, Issue No. 13, pp. 7-30.

Boschen, Timothy L and Charlottesville, Va (2001, December 6) "Shame and Guilt in Religious Fundamentalism", Christian Ethics Today, Vol. 7 Issue No. 037. 
Bush, Ray (1988). "Hunger in Sudan: The Case of Darfur", African Affairs the Journal of the Royal African Society, Vol. 87, No. 346-357, p. 5-38.

Collins, Robert O (1999, September) "Africans, Arabs, and Islamists: From the Conference Tables to the Battlefields in the Sudan", African Review, the African Studies Association, Vol. 42, No. 2, pp. 106-107.

de Waal, Alex (2005 January). "Briefing: Darfur, Sudan: Prospects for Peace", African Affairs, Royal African Society, Vol. 104, No. 114, pp. 129-143.

Deng, Francis Mading (1994). "Stop the carnage”, Brooking Review, Vol. 12, No. 1, pp. 46-76.

El-Affendi, Abdel Wahab (1990, July). "Discovering the South: Sudanese Dilemmas for Islam in Africa", African Affairs, the Journal of Royal African Society, Vol. 891 No. 356, pp. 371-475.

Hassanien, Ali Mahmoud (2006, May). "General Comments on Proposed Interim Constitution of Sudan”, Mahawir, Journal for the Sudanese Studies, Issue No. 13, pp. 31-45.

Hemmasi, Mohammad and Provok, Carolyn V (2002). "Demographic Changes in Iran's Officially Recognized Religious Minority Population since the Islamic Revolution", African and Asian Studies, Vol. 1, No. 2, pp. 63-84.

Jamal, Abbashar (1991, September). "Funding Fundamentalism: The Political Economy of an Islamist State", Middle East Report Vol. 172, pp. 15-30.

Kelsay, John (2003, October). “The New Jihad and Islamic Tradition”, Foreign Policy Research Institute, Vol. 11, No., p. 3.

Leblanc, Marie Nathale (1999, October). "The Production of Islamic Identities through Knowledge Claims in Bouke Cote d'Iviore", African Affairs, the Journal of the Royal African Society, Vol. 98 No. 393, pp. 485-501.

Lee, Raymond L. M. (2004). "The Transformation of Race Relations in Malaysia: From Ethnic Discourses to National Imagery, 1993-2003", African and Asian Studies, Vol. 3 No. 2, pp. 115-7.

Little, David (Summer, 1995). "Belief, Ethnicity and Nationalism", Nationalism and Ethnic Studies, Vol. 1, No. 2, pp. 284-301.

Mans, Ulrich (2004 April). "Briefing: Sudan: The New War in Darfur", African Affairs, the Journal of the Royal African Society, Vol. 103 No. 411, pp. 291-400.

Morton, John (20002). Ethnicity and Politics in Red Sea Province, Sudan, African Affairs, the Journal of the Royal African Society, Vol. 88 No. 350, p. 65-83.

Nor Adam, Baballa Haroun (1999). "Ethnic Composition, Economic Pattern and Armed Conflicts in Darfur", the Sudanese Human Rights Organization, the Sudanese Human Rights Quarterly, Issue No. 8, p 19.

Northey, W Brook and Morris, C J (1929). "Report of the Rejaf Language Conference, 1928", Bulletin of the School of Oriental and African Studies, Vol. 5. pp. 13-27.

Potter, W J (1996). An Analysis of Thinking and Research about Qualitative Methods, Mahwah, NJ: Lawrence Erlbaum. 
Preis, Ann-Belinda S (1996, May). "Human Rights as Cultural Practice: An Anthropological Critique”, Human Rights Quarterly, Vol. 18, No. 2, pp. 286-365. Prendergast, John (2005, February). "Resolving the Three Headed War from Hell in Southern Sudan, Northern Uganda and Darfur", African Program Occasional Paper Series, Woodrow Wilson International Center for Scholars, No. 3, pp. 1-21.

Salih, Kamal Osman (1990, June). "The Sudan, 1958-9: The Fading Democracy”, the Journal of Modern African Studies, Vol. 28, No. 2, pp. 199-224.

Sharkey, Heather J (2008, December 18). “Arab Identity and Ideology in Sudan: The Politics of Language, Ethnicity, and Race, African Affairs, the Royal African Society, Vol. 107, No. 426, pp. 21-43.

Southhall, Aidan (1976, December). "Nuer and Dinka Are People: Ecology, Ethnicity and Logical Possibility”, Man, New Series, Vol. 1, No. 4, pp. 463-491.

Sudan Human Rights Organisation (2000). "SHRO-.Cairo Report on Slavery in the Sudan”, The Sudanese Human Rights Quarterly, Issue No. 9, pp.3-25.

Sudan Human Rights Organisation (1999) "Human Rights Situation in Sudan, Extrajudicial Killings", the Sudanese Human Rights Organisation, the Sudanese Human Rights Quarterly an Ad hoc Publication, Issue No. 8, pp. 1-25.

Newspapers, Bulletins and Archives

AFP, (2009, August 23). "Sarkozy Sympathy to Hussein in Sudan", Agence France Press, Issue No. 1258, pp.1-16.

(2001). "Interview with Simon Karlo, Director of Education of Nuba Mountains", Agence France Press, Issue No. 1783, pp. 3-5.

African News (2001, April). "Yusuf Kuwa Makki, Life is a School with Great Lesson", African News, Issue No. 7561.

Akhbar al-Youm (2004, April), “Araba men Nheb al-Musalla Yawajahhoon al-Hokim bel Gatha Athahom fil Goreb al-Sudan Darfur, Four Armed Robbers Face Amputation in Sudan's Western Darfur", Arabic Newspaper, Akhbar al-Youm, http://www.arabic-radio.tv/newspapers/sudan/akhbaralyoum.htm.

Al-Hayat (2007, March 21). "About the Arab Stance vis-à-vis Darfur, Al-Hayat English Newspaper version, pp. 7-12.

Al-Waton (2008, December 4). "Al-Hokuma al-Sudania Ger Jada wa la Teltezem beItifaggiataha, The Government of Sudan Is not Genuine and Does not Honour Agreements", Al-Waton Arabic Newspaper, Issue No.782, pp. 3-8.

Amnesty International and SVTG (2001, February 23). "Medical Letter Writing Action, Fear of Amputation for 19 Men", Sudan, AI Index: AFR 54/005/2001Distrib: PG/SC http:www.asiapacific.amnesty.org/library/Index/ENGAFR540052001 ?open\&ofEN G-2AF

Amnesty International (2005, January 31). "Sudan: Those Responsible for Indiscriminate Port Sudan Killings must Be Brought to Justice", Amnesty International press Release, AI Index: AFR54/014/2005, News Service No: 024. 
Amnesty International (2007, October). "Editor-in Chief of Al-Wafaq Arabic Newspaper, Khartoum, Amnesty International press Release, AI Index: AFR54/014/2005, News Service No: 047.

Amnesty International (2005, March). "What Hope for the Future? Civilians in Urgent Need of Protection", Amnesty International AI Index: AFR54/ 164/ 2004.

Amnesty International (2003, July). "Empty Promises, Human Rights Violations in Government Controlled Areas, Amnesty International, AI Index: AFR54/036/2003.

Ban Hopes (2009 April, 7). "Ban Hopes Sudan Reverses Its Decision to Expels International NGOs" http//www. unmultimedia.org/radio/english/detail/72606.html

Badal, Raphael Koba (1983). Oil and Regional Sentiment in Southern Sudan, Syracuse: Discussion Paper No. 80, Department of Geography, Syracuse University Press.

Beginning of Integration (2003, January 12). Badaya al-Takamol al Faeli ma AlSudan, Al-Gensia al-Sudania lel Messereen shreth Asasi lel Hosul ala Geta Aradth fil Monaba al-Nil, The Beginning of the Practical Integration with Sudan, Sudanese Nationality for the Egyptians Is the Real Condition for the Acquisition of a Piece of Land on the Nile Valley", Arabic Newspaper, Al-Messa, Issue No. 1243, pp.1-3.

Coalition for Darfur (2005, December 2). "Unsimplifying Darfur" http//coalitionfordarfur.blogspot.com/2005//2unsiplifyingdarfur.html

Bulletin (1984) "Rejaf Conference Language", Bulletin of the Oriental Studies, University of London, p. 2-15.

Collins, Robert O (2005, February). "The Naivasha Enigma", www.betterlemonsinternational.org.

Comprehensive Peace (2005, January 9). Comprehensive Peace Agreement between the Government of Sudan and the Sudan People's Liberation Movement SPLM and Sudan people's Liberation Army SPLA, Kenya Nairobi.

Constitution of Sudan (1998). Constitution of the Republic of the Sudan Entered into Force July 1998.

Constitution of Sudan (1973). Constitution of the Republic of Sudan Entered into Force August 1973.

Constitution of Sudan (2005). Interim Constitution of the Republic of Sudan entered into Force Entered into Force July 2005.

Constitution of Sudan (2005). Constitutional Court Act of Sudan 1998 and Revised in 2005.

Convention on the Prevention and Punishment of the Crime of Genocide adopted by the Resolution 260 (III) A of the U.N. General Assembly on 9 December 1948.

Darfur Peace Agreement (2006 May). Darfur Peace Agreement, Abuja, http//www.allafrica.com/peaceafrica/resources/view/0001

de Waal, Alex (2006, December 22). "Averting Genocide in the Nuba Mountains, Sudan”, http://howgenocidesend.ssrc.org/de_waal2/printable.html.

Garang, John de Mabior (1985, March 7). Radio of the SPLM/A. 
Garang, John de Mabior (1985 April, 14). Radio of the SPLM/A.

Garang, John de Mabior (2005, 16 May). Chairman/C-IN-C, SPLM/SPLA Address to the SPLA and SPLM in Rumbek.

Garang, John de Mabior (2002, March). "Modalities for Peace in Sudan" a Political Paper Presented by John Garang at Carter Center in Atlanta on 20 March 2002.

Gassis, Macram Max in Mayo, David (ed.) (Autumn, 1994). "The Sudan Cincinnati Reaches out to Sudan", Newsletter, University of Pennsylvania African Studies Center, Vol., 4, pp. 12-16.

Gration on Sudan (2009, June 7). "Gration on Sudan Our approach Is very Comprehensive" http://www.enoughproject.org/blogs/gration-sudanour-approach very comprehensive

Hentoff, Nat (1996, August 20). "Here is the Proof, Mr. Farrakhan", Village Voice, Vol. 41 Issue 34.

Heritage (1987). "Dr John Garang de Mabior, Leader of the SPLM/A, Heritage Magazine, Khartoum, Vol. 1, Issue, 13, pp.1-4.

Hughes, John (1996, September 26). "Removing the Veil of Slavery and Exploitation”, Christian Science Monitor, Vol. 88, Issue, 212.

Human Rights Watch (1999). "New Islamic Penal Code Violates Basic Human Rights”, 4/91, 15 3.300/1.

Human Rights Watch (1998). "HRW Background Paper on the 1998 Famine in Bahr el-Ghazal, Sudan", http://www.hrw.org/campigns/sudan98/sudfam.htm.

Human Rights Watch (2000). World Report Entry, http://www.hrw.org/hrw/pubweb/webcat-93.htm

International Covenant on Civil and Political Rights Adopted and opened for signature, ratification and accession by General Assembly resolution 2200A (XX1) of 16 December 1966, entry into force 23 March 1976, in accordance with Article 49.

International Criminal Court, "Situation in Darfur", the Sudan, Summary of the Case, Prosecutor Application for the Warrant of Arrest under Article 58 against Omar Hassan Ahmed Al Bashir, Maanweg 174, 2516 AB The Hague, the Netherlands, 14. July 2008.

International Criminal Court http://www.icccpi.int/menus/icc/situations\%20and\%20cases/situations/situation\%20icc\%200205/ related\%20cases/icc02050109/icc02050109?lan=en-GB

Interim Constitution of the Republic of the Sudan entered into Force July 2005.

Juba Conference 12 June 1947 EP/SCR/1.A.5/1 Juba, 21 June, 1947, Deputy Governor of Bahr el-Ghazal/ Area, Wau.

Kane, Gregory p. (1998, September- October). "Slavery in the Sudan”, Headway, Vol. 10 Issue 8, pp. 24-36.

Khalid, Mansur (2007 April, 6). "Al.Onsoria in Islam", "Racism in Islam”, Sudanile Electronic Arabic Newsletter www.sudan.net 
Liben, Paul H (1995, August-September). "Murder in Sudan", First Things, Vol. 55, p. 42-44, htt://www.leaderu.com/ftissues/ft9508/liben.html.

Machakos Protocol Signed between the SPLM and Government of Sudan in 2003.

Macram Max Gassis (2000, 17 November). "Suffering of the People in Sudan" Bishop's Pastoral Letter appeal, pp. 1-20.

Mahmoud, Mohammad (1997, September 16-17). "Islam and Islamization in Sudan: The Islamic National Front", a paper Presented at a Conference on "Religion, Nationalism and Peace in Sudan", Washington: The United States Institute of Peace.

Manifesto (2008 April). Manifesto of the Sudan people's Liberation Movement.

Manifesto (1983, July). Manifesto of the Sudan People's Liberation Movement SPLM and Sudan people's Liberation Army SPLA July 1983.

Martin Agwai (2009, August 27). "War in Sudan's Darfur Is over" news.bbc.co.uk/17hi7world/Africa/8266314stm.

Mayo, David N (1994). "IGAAD Meditation Role in the Sudanese Conflict Reaches a Dead End Will the UN Security Council Take over from Them? The Sudan Newsletter, University of Pennsylvania, African Studies Center, Vol. 4 No. 3, pp. $1-2$.

McWilliams, Mike (2005, March 21-22). "Advocate to Spread Views Globally Asma Taha Fights for Women's Rights”, Iowa City Press Citizen, Vol. 146 pp. 2.5.

Middle East (Spring, 2003). "Sudanese Muslims, Christians Discuss 'Co-living and a Culture of Peace", the Middle East Council of Churches, News Report, Vol. 15, No. 1, pp. 1-20.

Middle East "Governor of the Nuba Mountains, Yusuf Kuwa Makki", Http://home.planet.nl/-ende0098/Articles/20010426.htm.

New Report on Genocide (2006, January 11). "New Report on Genocide in Darfur, Sudan, Documents Systematic Destruction of Livelihood of three Villages in Unprecedented Detail”, http://phrusa.org/research/sudan/news_200601-11html

Ninth Periodic Report (2008, March 20) 'Ninth Periodic Report of the United Nations High Commissioner for Human Rights on the Situation of Human Rights in the Sudan http//www.ohchr.org/documents/Press/WestDarfurreport2003.pdf

Op't End, Nanne (2001, February 12-13). "Interview with Yusuf Kuwa Makki", London. Http://home.planet.nl/-ende0098/Articles/20010426.htm.

Position paper of the SPLM in Peace Negotiation Nairobi, Kenya 1994.

Powel Reports (2004 September 9). "Powell Reports Sudan Responsible for Genocide in

Darfur"http://usinfo.state.gov/xarchives/displayhtml?p=ashfileenglish\&m=2004\& $\mathrm{m}=$ mseptember $\& \mathrm{x}=2004090911155958$ JTgnilwoDo50

Powell Reports (2004, September 9). "Powell Reports Sudan Responsible for Genocide in Darfur",

http://usinfo.state.gov/xacrchives/displayhtml?p=ashfileenglish\&m=2004\&m=msept ember \& $\mathrm{x}=20040909115958$ JTgnilwoDo50. 
Press Briefing (2007 February 28). "Situation: Darfur, Sudan", The Hague, ICC. OPT-2007227-208-En.

President Bush (2001, September). "President Bush Appoints Danforth as Special Envoy to the Sudan" http://www.whitehouse.org/news/release/2001/09/20010906/3html

President Omer Hassan el Bashir Satellite Address on Sudan National Television on 24. 2. 2007 to Nation of Islam in Detroit, United States of America.

Ray Aam (2008, July 17). "Al-Bashir: Jihaat Tahawel Al-Fitina lel-Istella aala Arathei Al-Hausa, Al-Bashir: Some Strive to Create Social Disorder to Occupy the lands of Hausa", Arabic Newspaper, Ray Aam pp. 1-4, http//:www.rayaam.net.

Ray Aam (2008, September 12). “Al-Bashir: Sudan lem ya-Shad Saraen Diniaen awau Irkia. Al-Bashir: Sudan Has Not Witnessed neither Religious Violence nor Genocide", Arabic newspaper, Ray Al-Aam, p. 1, http//:www.rayaam.net.

Ray Aam (2008, April 24). "Nafi Ali Nafi: Sanedafa Mashurua el-Hathari be kul wasael" "Nafi Ali Nafi: We will Defend the Project of Islamic Orientation by All Means", Arabic Newspaper, Ray Aam, pp. 1-3, http//:www.rayaam.net.

Ray Aam (2004, December 2). "Wazir Shuhoon Handessia fil Ali al-Nil" "Engineering Affairs Minister in Upper Nile", Arabic Newspaper Ray Aam, pp.1-12, http//:www.rayaam.net.

Ray Aam (2007, October 16). "Nafi, Ali Nafi, Yakathib al-Jamaheer fil Gatharef", Nafi Ali Nafi Addresses People in Gadaref', Arabic Newspaper, Ray Aam, pp.112. http//:www.rayaam.net.

Ray Aam (2008, July 27). “Alberto M. Fernandez, al- Kaim bel Amal-al-Ameriki fil Sudan; Lessna Missel Al-Sein: Awalietinna fil Sudan Seyaseya la Igtisadia, Alberto M Fernandez, Charge d'Affairs of the USA: We Are not Like China: Our Priority in Sudan Is political and not Economical", Arabic Newspaper, Ray Aam, Issue No. 9723, pp. 1-12.

Ray Aam (2004, December 2). "Wazir Shuhoon Handessia fil Ali al-Nil Engineering Affairs Minister in Upper Nile Muhammad Abas Muhammad Saeed Speaks", Arabic Newspaper Ray Aam, Issue No. 9724 p. 1-12.

Ray Aam (2006, February). "Al-Zuaj in Gadaref been al-Bit al-Mslima and Nasari, Marriage in Gadaref between the Muslim Girl and Christian", Arabic News-paper, Ray-Al-Aam, pp. 3-5, http// www.ray aam.net.

Ray Aam (2009, September 20). "Maraka thid al-kawarej fil Darfur War against the Insurgents in Darfur" Ray Aam Arabic Newspaper, http//www.rayaam.net.

Report of the Conference (1928). "Report of the Rejaf Language Conference", Sudan Government Wellington House, Buckingham Gates, S W 1, Education Department, Khartoum, and International Institute of African Languages and Cultures, 22, Craven Street, London, WC 2.

Reuters (2008 July, 21). "AU Calls for the UN to Suspend ICC Indictment of AlBashir”, Newspaper Reuters.

Reuters (2007, March 26). "Sudan Police, Darfur Former Rebels Clash 10 Dead", Reuters http://news.scotsman.com/latest.cfm?id=463512007. 
Reuters (2003, September). Sudan: Oil \& War, Review of the African Political Economy, PP. 504-5. Reuters http://news.scotsman.com/latest.cfm?id=463512007.

Rodolphe Adada (2009 October, 11). "Rodolphe Adada Address to the African Synod", www. Zenith.org/article-27153?1english

Satellite Live on the National Television of Sudan on Saturday 24.2.2007. President of Sudan, Field Marshal Omer Hassan el-Bashir Addressed the Muslim African Americans, Nation of Islam of Louis Farrakhan in Detroit, USA from Khartoum.

Seekers of Truth and Justice (2000). The Black Book: Imbalance of Power and Wealth in the Sudan http//www.sudanjiem.com/English/books/blackbook_part12004_bbone.htm.

Smucker, Philip (2001, March 21). "Market Thrives from Sudan Human capital", Christian Science Monitor, Vol., 93, Issue 80.

Steinberg, Donald (2007, December 14). "A Seat at the Table: the Role of Displaced Persons in Peace Talks and Rebuilding", a Paper Presented at the U.S. Institute of Peace, Washington DC.

Security Council (2004, September 18). United Nations Security Council Resolutions 1564 Adopted by the Security Council at Its Meeting on 18 September 204, S/RES/1564.

Shreq al-Awsat (2010, January 29). "Zaeem Harka Tahreer Al-Sudan Younafi Muthaliba Behaq Taqreer Al-Museer Li Darfur, The Leader of the SLM Denies the Demand for Self-Determination for Darfur" Shreq al-Aawast, Arabic Newspaper, Issue 11385 p. 2.

Shreq al-Awsat (2007, March 17). "Fatwa Jadida min Turabi: Rejim el-Zina Sharia Yhudia", The New Islamic Verdict: Turabi Stoning is a Judaism Law, Arabic Newspaper, Shreq al-Awsat, No., 10336.

Shreq al-Awsat (2007, December 22). "Government of Sudan Punishes the British Teacher, Gillian Gibbon”, English Version Newspaper, Shreq al-Awsat, Issue No. 10617.

Shreq al-Awsat (2007, July 2). "Turabi Ysamah al-Zwaj bean Bit Muslima wa Nassari" "Turabi Continues to Permit Marriage between a Christian and a Muslim Woman", Shreq al-Awsat Arabic Newspaper, Vol. 1078, pp. 1-2

Shreq al-Awsat (2007 March, 17). "Fatwa Jadida from Turabi: Rejim el-Zina Sharia Yhudia", The New Islamic Verdict: For Turabi, Stoning is a Judaism Law, Arabic Newspaper, Shreq al-Awsat, No. 10336, p. 3.

Shreq al-Awsat (2007, November 18). "Sudan's President Orders Paramilitary Forces Mobilisation, Rejects Abyei Report”, Shreq al-Awsat, Issue No. 10582.

Shreq al-Awsat (2007, July 2). "Turabi Ysamah al-Zwaj bean Bit Muslima wa Nassari" "Turabi Permits Marriage between a Christian and a Muslim Woman", Arabic Newspaper, Shreq al-Awsat, Vol. 1078, p. 2.

Shreq al-Awsat (2007, March 1). "Civilians of Darfur Want the President of Sudan to Stand before Justice: Most of Them Consider Him as the First to Be Punished at the International Criminal Court", English Version, Shreq al-Awsat, No. 10320, p. 1 . 
Shreq al-Awsat (2008 July, 13). "Al-Raiz al-Sudani Yawajah al-etigal” Sudan's President Faces Arrest", Arabic Newspaper, Shreq al-Awsat, Issue No. 10420, p. 1.

Shreq al-Awsat (2007, December 22). "Government of Sudan Punishes the British School Teacher, Gillian Gibbon, Arabic Newspaper, Shreq al-Awsat, Issue No., 10617, p. 1.

Shreq al-Awsat (2005). "Milik al-Saudi, Abdullah Bin Abdel Aziz Youdin Islamiyya Mutathrifa King Abdullah Bin Abdel Aziz of Saudi Arabia Condemns Islamic Radical Fighters", Arabic Newspaper, Shreq al-Awsat, No. 98923, p. 2.

Shreq al-Awsat (2007, May 23). "Sheikh Abd Al-Muhassen Al-Abikan: Al-Irhabeen Yasdhdafoun Sharayyia el-Din al-Islami Sheikh Abd Al-Muhassen Al-Abikan the Terrorists Target the Legitimacy of the Islamic Religion", Arabic Newspaper, Shreq al-Awsat No. 10403, p. 3.

Shreq al-Awsat (2007, March, 25). "Battle in Omdurman between the SLA and the Government Police”, English Version, Al-Shreq al-Awsat, No. 10335, p. 1.

Shreq al-Awsat (2006, February). "Fita Sudania Muslima tatazoj min Massiahe wa testanid le fatwa al Turabi. Sudanese Muslim Girl Marries from a Christian in Accordance to Turabi Edict", Arabic Newspaper, Shreq al-Awsat, No. 10037, p. 2.

Slavery Convention Signed at Geneva on 25 September 1926.

Speech of Musa Mohamed Ahmed, Leader of the Beja Congress in Asmara January 2005.

Sudan Tribune (2009, August). "Lubna Hussien Trial”, Sudan Tribune English Newspaper, http//www.sudantribune.net.

Sudan (1994). "Sudan Country Study", Washington, DC: Department of the Army p. $1-20$.

Sudanile (2008, July 25). "ICC Salah Jaded lel Natham Al-Bashir, ICC a New Weapon to the Regime of Al-Bashir", Sudanile Arabic Newspaper, http//www.sudan.net

Sudan Nile (2010, January 7). "Minnawi Itifakyyia al-Salam Darfur, Darfur Peace Agreement", Arabic electronic Newspaper, http//www.sudanile.com/index.php?option=comcontent $\&$ view $=$ articleie $\&$ id $=9477: 2010-01-07-06-16-43 \&$ catide $=42: 2008-05$.

Sudan (2009, June 11). "Sudan: Key Recent Development"http/www.securitycouncilreport.org/atf/cf/\%7B65BFCF9-6D274E9C-8CD3-CF6E4FF9FF9\%7D/July\%2009\%20FForecast.pdf

Sudan Penal (1991) Sudan Penal Code 1991.

Sudan Expels Agencies (2009, March 12) "Sudan Expels Aid Agencies after the ICC Warrant" www.reliefweb.int/rw/rwb.../CJAL-7PTQSF?...-

Sudan (2009, July 24) "Sudan: NGOs Expulsion to Hit Darfur Displaced" http://www.irinnews.org/report.aspx?Reportid=83370

Sudan Human Rights (2000). "SHRO-Cairo Report on Slavery in the Sudan", the Sudanese Human Right Quarterly, Issue No., 9, p.1-25.

Sudan Peace (2002, October). Sudan Peace Act, Washington, US Congressional. 
Sudanile (2008, July 25). ICC a New Weapon to the Regime of Al-Bashir, Sudanile Newspaper, Issue No., 951.

Sudani (2007, December 3). "Hokuma Sudania Hakim aala Messereen", "Government of Sudan Sentenced Egyptians", Sudani Arabic Newspaper, Issue No., 757.

Sudani (2008, July). "Nafi Ali Nafi Idaat Ocampo len Tathel Intikabat, Nafi Ali Nafi the Warrant Arrest of Ocampo Does not Obstruct Elections", Arabic Newspaper, Sudani, Issue No. 958, p. 1-15.

Sudani (2008, July 24). “Al-Bashir fil Darfu, Al-Bashir in Darfur”, Arabic Newspaper, Al-Sudani, Vol. 983, pp. 1-2.

Sudani (2007, March25) Omdurman Tashad Istibaakaat Damyia bean el Shurtha wa el Harka Minawi, Omdurman Witnesses Clashes between the Police and the Movement of Minawi, Arabic Newspaper, Sudani, No. 491, pp. 1-8.

Sudani (2007, March 30). “Al Berged Yatahamuun Kawaat Tab’ba le Minnawi beiktithaf Sita Afraad al Berged", "Al Berged Allege Minnawi Forces of Having Kidnapped Six Persons”, Arabic Newspaper, Sudani, No. 494, pp. 1-8.

Sudani (2007, December 3). "Hokuma Sudania Hakim aala Messereen", "Government of Sudan Sentenced Egyptians", Arabic Newspaper, Sudani, Issue No. 757, pp.1-8.

Sudani (2007, April 7). "Motemer al Watoni ya waqqa itifaqyyiaat wa fil nefes al waqt yerfoth al- tenfiith, "The National Congress Party, NCP Signs Agreements and at the Same Time Refuses to Implement Them" Arabic Newspaper, Sudani, 984, p. 1-8.

Sudani (2008, July). Nafi Ali Nafi Idaat Ocampo len Tathel Intikabat", "Nafi Ali Nafi the Warrant Arrest of Ocampo Does not Obstruct Elections", Arabic Newspaper, Sudani, Issue No. 958, pp. 1-8.

Sudani (2008, September 6). "Nafi Ali Nafi fil Misser, Nafi Ali Nafi in Egypt", Arabic Newspaper, Sudani, Issue, No. 961, pp. 1-8.

Suliman, Mohamed Suliman "A Major Causes of Armed Conflict in the Sudan. The Case of the Nuba Mountains", a Paper presented at International Conference on: Community Based Natural Resources Management, from 13-19 March 1998, Washington DC United States of America.

Turabi, Hassan Abdellah, "The Phenomenon of Political Terrorism and the Evaluation of the September Incident in America", an Article Written by Turabi, under the theme "Public Religious Muslim Enlightenment", Khartoum, 2002, January.

Sudan Television (1991). Sudan National Television Discusses with Martin Macuie Malual Arop, a Member of the Revolutionary Command Council.

Time (2008, July 22). Khartoum Considers Extradition of Haruon and Kosheib to Hague. Time Magazine.

UN Special Rapporteur (1995). "Gaspar Biro Introducing His Report to the UN", Commission on Human Rights April 16. 1996. ECOSOC, E/CN.4/1996/62, para.97 (a).

United Nation http//www.unhc.org/news/493805812.html 
UN Commission of Human Rights Report 2006.

United Nations Resolution (2004, July 30). United Nations Security Council Resolution 1556, Adopted by the Security Council at Its 5015 the Meeting, on 30 July 2004, S/RES/1556.

Universal Declaration of Human Rights http//www.un.org/events/humanrights/udhr60/.

UN Special Rapporteur (1995, April 16). "Gaspar Biro Introducing His Report to the UN, Commission on Human Rights”, ECOSOC, E/CN.4/1996/62, para.97 (a)

UN Special Rapporteur (1994). "Implementation of the Declaration on the Implementation of All Forms of Intolerance and Discrimination Based on Religion and Belief", Commission of Human Rights, Dis. General E/CN.4/.

UN Panel (2004, October 7). "U.N. Panel Named to Investigate Charges of Genocide in Darfur. Annan Picks Five Jurists to Look into Violations of International", http://usinfo.state.gov/xarchives/dispaly.html?p=washfileenglish\& $\mathrm{y}=2004 \& \mathrm{~m}=0 \mathrm{ct}$ ober \&x=20041007171634atiayduj0.821209

UN (2008, June 18). "Highlights of the Noon Briefing by Michele Montas, Spokesperson for the Secretary General Ban Ki-Moon, UN Headquarters", New York.

UN Emergency Jan Egeland Report (2005). “United Nations Humanitarian

Chief Jan Egeland Pleads with Sudan to Allow Aid to Darfur", http://www.pbs.org/newshour/bb/international/jan-juneegeland_05-09.html.

UN Commission of Human Rights (2006). UN Commission of Human Rights Report in Sudan.

United Nations (2008, August 26). "Statement of the United nations humanitarian Coordinator, Ameerah Haq on Kalma Camp", http://www.un.org/News/ossg/hilities/hilities_arch_view.asp?HighID=1145.

U.S. Response (2005, January 31). "Response to the Release of a Report by the U.N.

International Commission of Inquiry on Darfur, Http://usinfo.state.gov/xarchives/displa.html?p=washfileenglish\&y=2005\&m=Febr uary $\& x=20050201171210$ wcyeroco. 7012

U.S. Official Investigation (2004 July, 24). "US Official Investigation Allegations of Genocide http//www.jmm.aaa.net.au/articles/14422

US Official Investigation (2004, July 24). "US Official Investigation Allegation of Genocide in Darfur, Sudan, Secretary Powell to Visit Region, Meet with Sudanese Officials" http://usinfo.stategov/xarchives/display.html=washfileenglish $=2004 \& \mathrm{~m}=20040624174556$ ntely0b60.7700464

United States Congress (2004, July 23). "U.S. Congress Terms Situation in Darfur Genocide" $\mathrm{http} / /$ search.state.gov/search?q=Darfur+genocidefilter $=0$ \&entqr $=3 \& u d=1 \&$ sort $=\mathrm{d}$ ate $\% 3 \mathrm{AD} \% 3 \mathrm{AL} \% 3 \mathrm{AD} 1 \&$ output $=\mathrm{xml}-\mathrm{No}-$ 


\section{APPENDICES}

\section{Appendix 1}

Questionnaire

Please, answer the below questions by circling and writing on your choice. You can write in English and Arabic at the given spaces. You can also use extra paper sheet(s), if the given space is not enough for your answers. You are free to skip the question that you do not want to answer as well as remaining anonymous.

1. Your Background

a. Name

b. Racial/ ethnic/tribal group

i. Arab from ethnic/tribal group

ii. African from Ethnic/tribal group

c. Gender

i. Male

ii. Female

2. Region.

a. Your regional background

i. Far North

ii. South Sudan

iii. Darfur (west Sudan)

iv. Nuba Mountains (west Sudan)

v. East Sudan

vi. Centre (El-Gezira) or Khartoum

b. How did the east, west, far north and centre become the Northern Sudan Region in exclusion of the South and what does the name of your region mean in your native language and do you experience any difficulty in articulating it? 
c. Do you think the exclusion of the South has a link with the past civil wars between the South and the North, and if you think so, what about the current violence within the North Sudan as in Darfur, how do you evaluate it?

d. Have you ever experienced any form of discrimination in any region of Sudan, if so please explain? 
e. How do you want a national identity of these regions to be defined in a national constitution of Sudan and under what system suits Sudan best and why do you think so?

f. Do you think that cross-marriages can curtail regional diversity in Sudan and if so; what marriage do you prefer and explain why?

i. Exogamous marriage

ii. Endogamous marriage

iii. Any other 
g. Do you think national projects such as oil; Canal Jonglei and Al-Gezira Scheme can create cross interaction and equal work opportunities for the diverse regions of Sudan, if yes or not, please explain?

\section{Your Religious Background}

a. Your religious affiliation/identity
i. Christian
ii. Muslim
iii. Animist
iv. Christian-Animist
v. Muslim -Animist.
vi. Agnostic
vii. Any other

b. Is religion important and what is your concept about the world in accordance to your religion, does it allow space for other religion(s), if so, please explain? 
c. How conversion from one religion to another religion in Sudan is conducted; do you encounter an obstruction on the process and have you ever felt that there has been an interference of your ethnic customs, cultures and traditions to your religion, if yes, please explain? 
d. What do you think about the people in Sudan who follow other religious faith and traditional rituals than yours, and please state the reason of why you think so?

i. Lost Sudanese Brothers

ii. Free Sudanese Brothers

iii. Any Other

e. How many festivals do you celebrate in your religion; where; how do you offer sacrifice and do you face restriction or limitation of worship in anywhere within Sudan? 
f. What are the fundamental duties of the faithful ones in your religion and is there any division of roles in terms of gender?

g. What is a practice in your religion regarded as sinful, indecent and immoral in which a violator is sentenced, what you think of it and how to deal with believers of other religion(s) violating the same practice in Sudan? 


\section{Appendix 2}

1. Questions for the Interview

a. You define yourself in the question of religious affiliation in the questionnaire as 'Christian-Animist' or 'Muslim-Animist' how do you reconcile Christianity or Islam with Animism in Sudan?

b. Having answered the question in the questionnaire, 'How do you want national identity of these regions to be defined in a national constitution of Sudan and under what system suits Sudan best and why do you think so? You described assimilation in Sudan as 'anomia', what do you mean?

c. In your answer to the question, 'Have you ever experienced any form of discrimination in any region of Sudan, if so please explain? You claim that a police urged you to define the face as 'brown' than your descriptive choice 'black'; what do you think about the obligatory description of the Ministry for the Interior Affairs the face as 'brown' than 'black' in national documents of the citizens in Sudan? 


\section{Appendix 3}

\section{Historical background for the search of a national identity in Sudan.}

In 1954, just before implementation of independence of Sudan from Great Britain, British academic constitutional experts drafted a constitution for the state. During that time, two conflicting issues over the form of a constitution that suited the nation state between a federal one or unitary constitution developed between the representatives of the Christian-Animist-South and the Islamic-Arab-North, which were represented by the Islamic sectarian parties, the Umma and the Democratic Unionist Party (DUP). Politicians from the Christian-Animist-South urged the provision of the South a federal system to be codified to a permanent national constitution. In response, the political forces of the Islamic-Arab-North embraced this demand to be given after independence. $^{1107}$

In August 1955, the 'Southern Defence Corps'(SDC) composed of the ChristianAnimist and stationed in Torit, South Sudan rejected participation in celebration of Sudan's independence from Great Britain and staged a mutiny against the Islamic North. The SDC killed the Muslim Arab soldiers and Muslim-Arab civilians in the town. ${ }^{1108}$ On 1 January 1956, The British endorsed independence and the Government of Sudan, under the DUP rejected the provision of the federation to the ChristianAnimist-South, but the inherited constitution from British that preserved religious and ethnic diversity was in operation. ${ }^{1109}$ In 1958 , the democratically elected first national assembly composed of one hundred and seventy three Members of the Parliament (MPs) coming from the Umma, the DUP and the Federal Party (FP) a political organisation represented the Christian-Animist South started to discuss the issue of national identity. During the parliamentary debates about the constitutional system in

\footnotetext{
${ }^{1107}$ Johnson, Douglas Hamilton (2003). The Root Causes of Sudan's Civil Wars, Oxford: James Currey, pp. 30-34.

${ }^{1108}$ Wai, Dunstan M (1980). "Pax Britannica and the Southern Sudan, the View from the Theatre", African Affairs, the Journal of the Royal African Society, Vol. 79, No. 316, p. 71.

${ }^{1109}$ Johnson, Douglas Hamilton (2003). The Root Causes of Sudan's Civil Wars, Oxford: James Currey, pp. 30-34.
} 
the state, the forty MPs from the Christian-Animist-South urged the Islamic-North political parties in the parliament to legislate two equal religions and equal languages in the state. In their view, both Arabic and English should be taught in the South and Islam and Christianity should be legalised on equal status in national institutions of the country. The MPs maintained that the Christian-Animist population of the South should not be culturally oriented towards the Islamic Arab world, but that of Africa. They also requested the provision of federalism and maintenance of the existing Southern independent army. In reaction, the Islamic Arab political majority rejected these demands and urged the adoption of the Islamic constitution, where the criminal and civil laws are derived from Sharia and Arabic be an official language of the state.

In June 1958, the Muslim majority agreed to pass the Islamic bill in the parliament, but the forty Christian-Animist MPs walked away from the parliament. On the following day, the indigenous African-Muslim-politicians from Darfur, Nuba and Beja united with the Christian-Animist-South and demanded the necessity of decentralisation, instead of centralisation of Sudan system. ${ }^{1110}$ After five months of the contest over the issue of national identity, the Northern Muslim democratic leaders were dissatisfied over the resistance they faced from the MPs of the Christian-Animist South and their alternative was rumoured to be a handing over of power to an Arab Muslim military man to dictate the ideological terms of assimilation to the Islamic identity through an Islamic constitution. ${ }^{1111}$ On 17 November 1958, the Commanderin Chief of the army, General Ibrahim Abboud seized power and proclaimed himself as the President of the state. In May 1962, Abboud introduced a bill known as the 'Missionary Societies Act', which defined regulations for the non-Muslim religious activities within the state. In February 1964 three hundred Christian missionaries were expelled from the territorial Sudan. Institutions of education in the South were entirely Arabised. Sunday as the day of worship for the Christians was substituted with Friday, the Muslims' worship day. ${ }^{1112}$

\footnotetext{
${ }^{1110}$ Sanderson, Lilian Passmore and G N Sanderson (1983). Education, Religion and Politics in Southern Sudan, London Ithaca, pp. 353-356.

${ }^{1111}$ Lesch, Ann Mosely (1998). The Sudan Contested National Identities, London: James Currey, p. 37.

1112 Alier, Abel (1990). Southern Sudan: Too Many Agreements Dishonored, Reading: Ithaca Press, p. 24.
} 
In October 1964, popular uprising forced Abboud to resign. Sirr al-Khatim alKhaliffa became the Prime Minister of the Transitional Government and started contacts with political Christian Animist-activists from the South to resume political discussion on the issue of national identity. In March 1965, a conference known as the 'Round Table Conference' was held in Khartoum and its agenda was to address the conflict of identity. Political figures from the Islamic North and Christian-Animist South attended the conference, but with different visions of constitutional formula. Political organisations from the Christian-Animist South were divided as the Sudan African National Union (SANU) rifted to two factions. One of them negotiated for the exceptional provision of federalism to the South, while the other demanded total independence from the Islamic North and the Southern Front, PF asserted the right of the Christian-Animist-South to self-determination. African observers proposed the formation of a 'Twelve Men Committee' composed of equal number of representatives from the Christian-Animist-South and the Islamic-Arab-North. Their mandate was to draft a new constitution. The representatives of the conference proposed the system which might embrace all forms of religious faiths and negotiated them and finally endorsed the proposal which recommended the maintenance of religious diversity. Their recommendation, however, was not implemented as the transitional period ended and the multi party democratic system resumed power in April 1965 and in the subsequent democratic elections of April 1968. Throughout this democratic period, political debates focused on finding a constitutional system which addressed the issue of national identity. All attempts of finding alternatives could not be reached, because of the divisions between the Christian-Animist-South and the Islamic-Arab-North. The Northern Muslims and Arabs at the national legislature asserted un-changed position which asserted Sharia as a source of both civil and criminal legal codes and Arabic as an official language of the state. On the contrary, the Christian-Animist-people of the South again resisted such constitution and defined it as a discriminating initiative towards the non-Muslims and the non-Arabs within the territorial state. $^{1113}$

${ }^{1113}$ Lesch, Ann Mosely (1998). The Sudan Contested National Identities, London: James Currey, p. 37. 
On 25 May 1969, colonel Ja'afer Muhammad Nimeiri an officer in the army seized power and settled the problem of national identity with the Christian-Animist-South in political negotiations held in Addis Ababa, Ethiopia in 1972. The 'Addis Ababa Agreement' endorsed the system which respected the existing diversity of ethnic and religious pluralism within a unified territorial Sudan. The agreement gave regional self autonomy system to the Christian-Animist-South centralised in Juba as a capital of the unified provinces of Bahr el-Ghazal, Equatoria and Upper Nile in South Sudan. $^{1114}$

In 1979, President Nimeiri introduced intensive measures to dismantle the Addis Ababa Agreement. First, he instructed the Attorney General, Hassan Abdullah Turabi to produce a bill in the parliament of one party system (SSU) to annex the rich oil territories from the South to the North. ${ }^{1115}$ Second, he decreed the re-division of the unified South composed of the above mentioned three provinces into disintegrated three regions. In this perspective, some Christian-Animist politicians of the Southern identity reacted and interpreted those measures as serious violations of chapter 1, 2: iii of the Addis Ababa Agreement and some of them decided to take up arms against Nimeiri. On 16 May 1983, some soldiers mainly from the Christian-Animist Dinka, Nuer and Shilluk ethnic groups widely known as Nilotics rebelled against the regime of Nimeiri and formed the SPLA and SPLM, a political wing. ${ }^{1116}$

In September 1983, Nimeiri unilaterally imposed Sharia and declared it as the only source of legal organs in Sudan. ${ }^{1117}$ In 1985, the Umma party, SCP with other different political organisations of the opposition, including the SPLM united under umbrella of NANS and held a meeting in London. After a long deliberation, the

\footnotetext{
1114 Johnson, Douglas Hamilton (2003). The Root Causes of Sudan's Civil Wars, Oxford: James Currey, p. 56.

${ }^{1115}$ Badal, Raphael Koba (1983). Oil and Regional Sentiment in Southern Sudan, Syracuse: Discussion Paper No. 80, Department of Geography, Syracuse University Press, p. 37.

${ }^{1116}$ Badal, Raphael Koba (1983). Oil and Regional Sentiment in Southern Sudan, Syracuse: Discussion Paper No. 80, Department of Geography, Syracuse University Press, p. 20.

${ }^{1117}$ Fluehr-Lobban, Carolyn (1987). Islamic Law and Society in the Sudan, London: Frank Cass, p. 280 .
} 
NANS issued a charter that called for the restoration and adoption of the provisional constitution of 1956, which preserved religious diversity in the country. ${ }^{1118}$

In April 1985, popular uprising dismantled Nimeiri regime and General Suwar alDhab filled the vacuum of power, however, he continued to maintain Sharia. On 10 October the transitional government adopted the provisional constitution of 1956 and amended in 1964, which considered both Sharia and the customary laws as sources of legislature. The SPLM was dissatisfied with the maintenance of Sharia and urged Suwar al Dhab to restore secular laws. In April 1986, Suwar al Dhab returned power to the democratically elected government. Umma and DUP parties formed a coalition government, in which Sadiq al-Mahdi from the Umma became a Prime Minister and countered three major problems and dilemmas. First, he had an obligation to implement the charter, which his party signed with the NANS in London 1985. Second, he had ratified with the SPLM a charter, 'Koka Dam Declaration' in March 1986. Both charters invoked the abrogation of Sharia. Third, the DUP, which shared power with his party, rejected the Koka Dam Declaration. ${ }^{1119}$

In June 1989, the Umma, DUP, SCP, USAP and other political forces with the exception of the NIF acquiesced to the pressure of the SPLM to abrogate Sharia. These political parties started to 'freeze' Sharia in the National Assembly, but the Islamists were unhappy on this initiative, but they were minority in the parliament. On 29 June 1989 Brigadier Omer Hassan Ahmed Al-Bashir seized power from the democratically elected government and declared himself President of Sudan. AlBashir called his military regime as the 'Salvation Revolution'. Under Al-Bashir, all the political parties were banned and Sharia was declared to be a sole guidance for all the people within the sovereignty of the country. ${ }^{1120}$

\footnotetext{
${ }^{1118}$ Burr, J Millard and Robert, O. Collins (1994). Requiem for the Sudan: War, Drought and Disaster Relief on the Nile, Boulder: Westview, p. 74.

${ }^{1119}$ Kok, Peter Nyot (1996). Governance and Conflict in the Sudan, 1985-1995, Hamburg: Deutsches Orient-Institut, p. 120.

${ }^{1120}$ Lesch, Ann Mosely (1998). The Sudan Contested National Identities, London: James Currey, p. 113.
} 
